\title{
Deep Explosive Volcanism on the Gakkel Ridge and Seismological Constraints on Shallow Recharge at TAG Active Mound
}

\author{
By \\ Claire Willis Pontbriand

\begin{abstract}
M.S. Statistics, University of Virginia, 2007
Doctor of Philosophy

at the

MASSACHUSETTS INSTITUTE OF TECHNOLOGY

and the

WOODS HOLE OCEANOGRAPHIC INSTITUTION
\end{abstract} \\ B.A. Mathematics and Economics, University of Virginia, 2006 \\ Submitted in partial fulfillment of the requirements for the degree of
}

February 2013

(C) 2013 Claire Willis Pontbriand

All rights reserved.

The author hereby grants to MIT and WHOI permission to reproduce and to distribute publicly paper and electronic copies of this thesis document in whole or in part in any medium now known or hereafter created.

Signature of Author

Joint Program in Oceanography/Applied Ocean Science and Engineering Massachusetts Institute of Technology and Woods Hole Oceanographic Institution

January 4, 2013

Certified by

Robert A. Sohn, Thesis Supervisor

Certified by

S. Adam Soule, Thesis Supervisor

Accepted by

Rob L. Evans

Chair, Joint Committee for Marine Geology and Geophysics Massachusetts Institute of Technology/ Woods Hole Oceanographic Institution 


\title{
Deep Explosive Volcanism on the Gakkel Ridge and Seismological Constraints on Shallow Recharge at TAG Active Mound
}

\author{
By \\ Claire Willis Pontbriand \\ Submitted to the department of Marine Geology and Geophysics, \\ MIT/WHOI Joint Program in Oceanography/Applied Ocean Science and Engineering \\ On January 4, 2013 in partial fulfillment of the requirements \\ for the degree of Doctor of Philosophy
}

\begin{abstract}
Seafloor digital imagery and bathymetric data are used to evaluate the volcanic characteristics of the $85^{\circ} \mathrm{E}$ segment of the ultraslow spreading Gakkel Ridge ( $\left.9 \mathrm{~mm} \mathrm{yr}^{-1}\right)$. Imagery reveals that ridges and volcanic cones in the axial valley are covered by numerous, small-volume lava flows, including a few flows fresh enough to have potentially erupted during the 1999 seismic swarm at the site. The morphology and distribution of volcaniclastic deposits observed on the seafloor at depths of $\sim 3800 \mathrm{~m}$, greater than the critical point for steam generation, are consistent with having formed by explosive discharge of magma and $\mathrm{CO}_{2}$ from source vents.

Microearthquakes recorded on a $200 \mathrm{~m}$ aperture seismometer network deployed on the Trans-Atlantic Geotraverse active mound, a seafloor massive sulfide on the Mid-Atlantic Ridge at $26^{\circ} \mathrm{N}$, are used to image subsurface processes at the hydrothermal system. Over nine-months, 32,078 local microearthquakes $\left(\mathrm{M}_{\mathrm{L}}=-1\right)$ with single-phase arrivals cluster on the southwest flank of the deposit at depths $<125 \mathrm{~m}$. Microearthquakes characteristics are consistent with reaction-driven cracking driven by anhydrite deposition in the shallow secondary circulation system. Exit fluid temperatures recorded at diffuse vents on the mound during the microearthquake study are used to explore linkages between seismicity and venting.
\end{abstract}

Thesis Supervisor: Robert A. Sohn

Title: Associate Scientist with Tenure, WHOI

Thesis Co-Supervisor: S. Adam Soule

Title: Associate Scientist, WHOI 


\section{Acknowledgments}

I owe my deepest gratitude to my advisers, Rob Sohn and Adam Soule, for their invaluable guidance, continual patience and support throughout the course of my graduate work. They contributed enormous energy and enthusiasm to my research and taught me how to question, pursue knowledge, and take chances. I would like to express great appreciation to all the members of my thesis committee for their insights during the preparation of this thesis: Andy Solow, Jeff McGuire, Nafi Toksöz, and Meg Tivey. I would especially like to thank Andy Solow for guidance on statistical methods; Jeff McGuire for sharing his expertise in seismology and for the field experience of working on an active source survey; Nafi Toksöz and the MIT Earth Resources Laboratory, including Fuxian Song and Junlun Li, for sharing their work on small-scale seismics; and Meg Tivey for her knowledge of the geochemical processes and structure of the TAG active mound. I would also like to thank my Thesis Defense Chair, Susan Humphris, for her feedback and patient explanations of Gakkel Ridge geochemistry. It is an honor for me to benefit from the expertise of these scientists.

I wish to acknowledge the help provided by Alison Shaw, Horst Marschall, John Bailey, John Kemp, William Lange and the Advanced Imaging Laboratory at WHOI, WHOI Graphics, and the crew of icebreaker I/B Oden. I thank Paul Craddock for mapping fractures local to the TAG active mound. I would also like to acknowledge Greg Hirth and Andrew McCaig for discussions on microearthquake source mechanisms. Thanks to Shaul Hurwitz for the internship at USGS Menlo Park and Yellowstone field experience.

Assistance provided by the WHOI Academic Programs Office, especially Julia Westwater, is greatly appreciated. I would like to extend thanks to Jim Yoder for allowing me a voice about the direction of the program, and the JCMG\&G, especially Rob Evans, for encouraging my progress. I wish to acknowledge my professors, especially Ralph Stephen, Jack Whitehead, and Lauren Mullineaux, for their engaging teaching. Thanks to my administrator, Kelly Servant, for her encouragement, and to my fellow students in the Joint Program and WHOI postdocs for their company, especially Nathan Miller, Min Xu, Shane McGary, Min Ding, Helen Feng, Evy Mervine, Arthur Olive, Camillo Ponton, Karin Lemkau, Dorsey Wanless, and Emily Roland.

I would like to express my gratitude to Cliff Pontbriand for his unconditional love and occasional distractions; to Martin and Sandy Willis for being my first and eternal educators; to Taylor Willis for his inspirational curiosity; to Lauren Lovett for her resolute advice; and to Tom and Colleen Pontbriand for their unfailing moral support.

My research was funded by a National Defense Science and Engineering Graduate Fellowship, the Woods Hole Oceanographic Institution Deep Ocean Exploration Institute fellowship, graduate support from the Woods Hole Oceanographic Institution Academic Programs Office, and NSF Award 0137329 for TAG active mound research (PI: Rob Sohn). 


\section{Table of Contents}

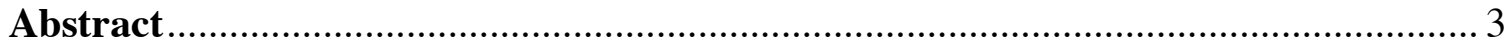

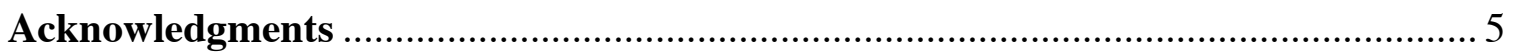

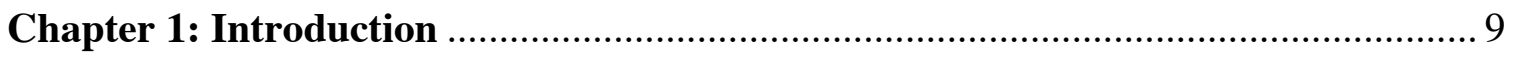

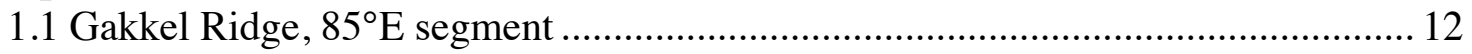

1.2 The TAG active mound, Mid-Atlantic Ridge $\left(26^{\circ} 08^{\prime} \mathrm{N}\right)$...................................... 14

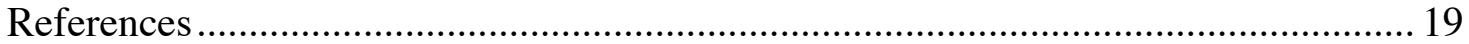

Chapter 2: Effusive and explosive volcanism on the ultraslow-spreading Gakkel Ridge, $8^{\circ} \mathbf{E}^{*}$

Chapter 3: Reaction-driven microearthquakes at the Trans-Atlantic Geotraverse (TAG) active mound, Mid-Atlantic Ridge, $\mathbf{2 6}^{\circ} \mathbf{0 8}$ 'N ……....................................... 53

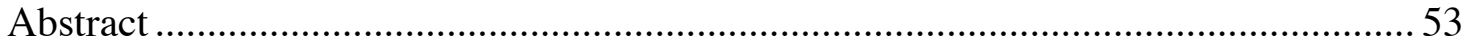

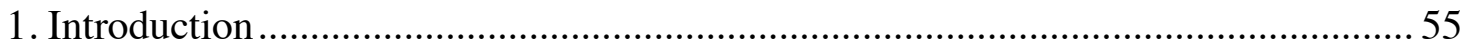

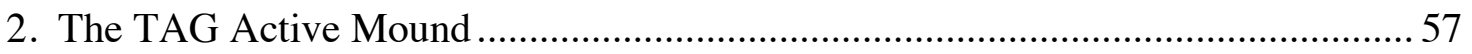

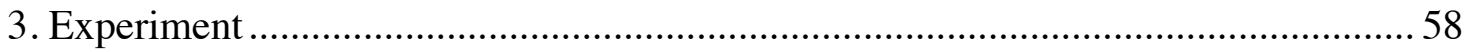

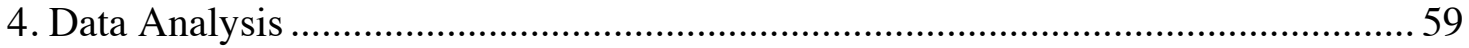

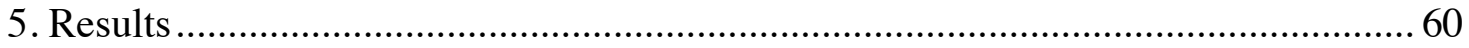

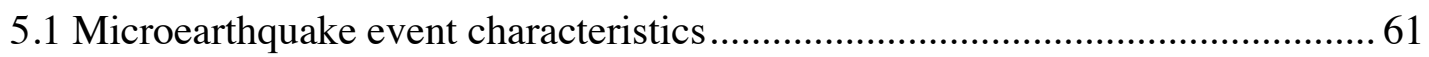

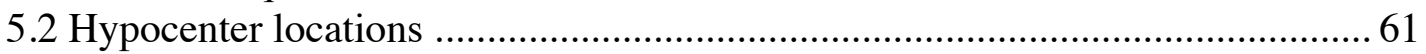

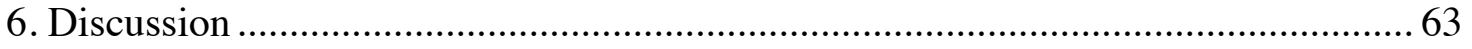

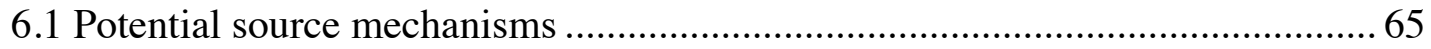

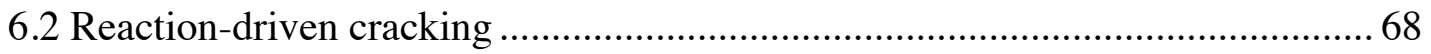

6.3 Implications for Anhydrite Precipitation ........................................................... 73

6.4 Implications of reaction-driven cracking in the TAG active mound subsurface 75

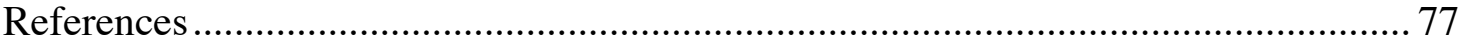

Chapter 4: Statistical assessment of the correlation between microearthquake activity and exit-fluid temperatures at the Trans-Atlantic Geotraverse active

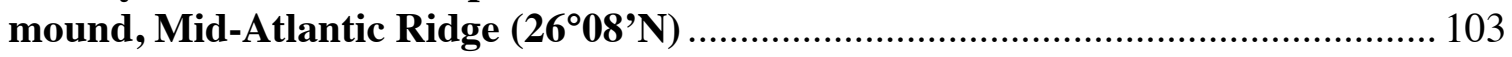

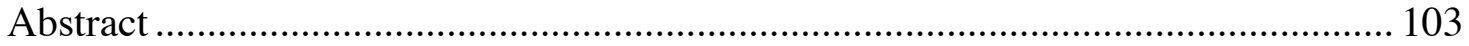

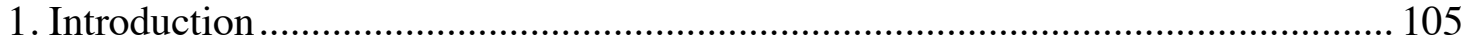

2. Hydrothermal Flow Records from the TAG Active Mound .................................... 106

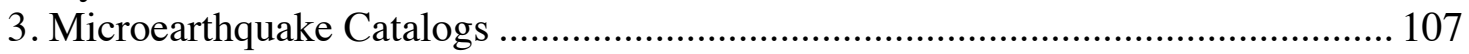

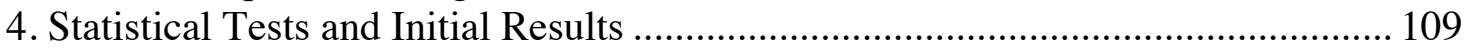

4.1 Spectral coherence: Microearthquakes vs. exit fluid temperatures ................. 110

4.2 Nonparametric rotation test for behavioral point process data .......................... 112

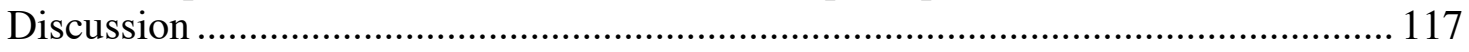

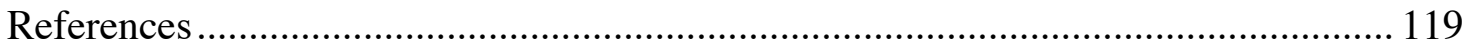




\section{Chapter 1: Introduction}

The mid-ocean ridges, the Earth's longest system of mountains, mark the limbs of rising convection cells in the mantle, where rigid tectonic plates move apart and new seafloor material rises to fill the vacant space. The generation of new plate material (i.e. oceanic lithosphere) occurs by seafloor spreading along the active mid-ocean ridges. Oceanic crust is formed by the intrusion of basaltic magma from below, and contact with seawater convection of seawater through the crust provides an efficient cooling mechanism. Convection of the seawater through the crust can result in hydrothermal venting, where hot hydrothermal fluids are formed through interactions of seawater with oceanic crust, modifying the composition of the crust, affecting ocean chemistry, building metal-rich deposits, and providing energy for deep sea biological communities. Both volcanism and hydrothermal circulation transfer mass and energy from the crust and mantle to the oceans. Volcanic processes at mid-ocean ridges (MORs) generate the oceanic crust comprising more than $60 \%$ of the Earth's solid surface. Hydrothermal circulation through permeable crust, driven by heat [Lister, 1972; Strens and Cann, 1986], contributes to transport of heat from the lithosphere to the oceans, which is estimated to account for $30 \%$ of the predicted global oceanic heat flux and almost $25 \%$ of the total heat flux of the Earth [Sclater et al., 1980; Stein and Stein, 1994].

Spreading rates along the global MOR system range from ultrafast $\left(>160 \mathrm{~mm} \mathrm{kyr}^{-1}\right.$ full rate) to ultraslow $\left(<12 \mathrm{~mm} \mathrm{kyr}^{-1}\right)$. Plate spreading rate is perhaps the dominant parameter controlling crustal accretion and volcanic processes at MORs, with faster spreading ridges exhibiting a higher magma supply rate and a hotter thermal structure compared to slower spreading ridges [Macdonald et al., 1982; Smith and Cann, 1993; Perfit and Chadwick, 1998; Edwards et al., 2001; Sinton et al., 2002; Cann and Smith, 2005; Cochran, 2008; Searle et al., 2010]. Fast-spreading ridges experience frequent (order 10$100 \mathrm{yrs}$ ), small-volume volcanic eruptions on narrow neovolcanic zones along axis, believed to reflect a high, continuous magma supply rate to the ridge [e.g., Macdonald et al., 1982; Perfit and Chadwick, 1998; Sinton et al., 2002]. The resulting ridge 
morphology is an axial high with a narrow graben along the ridge crest [Small, 1994; Fornari et al., 2004; Soule et al., 2009]. At slow-spreading ridges, the dominant morphologic feature is a rift valley, believed to reflect lower and intermittent magma supply rates and increased tectonism [Langmuir et al., 1992; Rubin and Sinton, 2007; Behn and Ito, 2008]. Volcanic eruptions at slow spreading ridges are thought to be infrequent (order 1000-10,000 yrs) and produce discrete point-source volcanic constructions across the rift valley floor [Smith and Cann, 1993; Edwards et al., 2001; Cann and Smith, 2005; Cochran et al, 2008; Searle et al., 2010].

Melting models of MORs predict a dramatic decrease in magma production and crustal thickness with decrease in spreading rate [Reid and Jackson, 1981; Bown and White, 1994]. Based on sparse observations it has also been suggested that eruption volume should vary inversely with spreading rate with the largest eruption volumes at ultraslow spreading ridges [Perfit and Chadwick, 1998; Sinton et al., 2002]. Sinton et al. [2002] hypothesize that because ephemeral magma chambers at ultraslow spreading ridges lie beneath thicker, stronger lithospheric lids, they require larger pressures for eruption, leading to longer repose intervals and larger volume eruptions $\left(\sim 10-100 \mathrm{~km}^{3}\right)$. The Gakkel Ridge figures prominently in this model as an end-member in terms of spreading rate and eruption volume, and the hydrothermally and volcanically active $85^{\circ} \mathrm{E}$ segment is particularly well-suited to serve as a study site for observing recent volcanism at ultraslow spreading rates.

Melting models of MORs also predict that a decrease in crustal magma storage with decrease in spreading rate should result in a corresponding decrease in hydrothermal activity [Baker, et al., 1994]. Although a compilation of observations at ridge segments of different spreading rates shows a robust linear trend between spreading rate and spatial frequency of hydrothermal venting [Baker et al., 2004], investigations of vent fields along fast-, medium and slow-spreading ridges have shown that the largest hydrothermal deposits tend to be found on slower-spreading ridges [Hannington et al., 1995; Tivey, 
2007]. Seafloor massive sulfide deposits found at slow-spreading ridges, like the TAG active mound on the MAR, are the modern equivalents of ancient ophiolite-hosted ore deposits, such as those mined for copper and gold in Cyprus, Oman, and Newfoundland [Humphris et al., 1995; Hannington et al., 1998; Humphris and Cann, 2000]. Many questions remain in our understanding of the factors that control focused hydrothermal venting and deposit-building on the seafloor [c.f. German and Von Damm, 2004; Hannington et al., 2005], but at many Atlantic vent fields, including the TAG hydrothermal field, large hydrothermal deposits are associated with detachment faults [deMartin et al., 2007], suggesting that detachment faults commonly act as channels for focusing of primary hydrothermal circulation at slow-spreading ridges [McCaig et al., 2007]. Genesis of a seafloor massive sulfide deposit requires a magma supply, which is thought to control detachment fault formation [Behn and Ito, 2008], a primary system of hydrothermal circulation that extracts heat from the source, and a secondary circulation system that entrains seawater to cool the shallow deposit and fuel mineral precipitation [Sleep, 1991; Tivey et al., 1995; Lowell and Yao, 2002; Lowell et al., 2003].

The purpose of this thesis is to better understand volcanic and hydrothermal processes in two particular mid-ocean ridge settings: the ultraslow-spreading Gakkel Ridge at $85^{\circ} \mathrm{E}$ in the Arctic Ocean and the TAG active mound in the TAG hydrothermal field on the slowspreading Mid-Atlantic Ridge at $26^{\circ} 08^{\prime} \mathrm{N}$. The work presented in this thesis was designed to:

a) identify and determine volcanic characteristics of the ultraslow-spreading Gakkel Ridge at $85^{\circ} \mathrm{E}$ on the scale of individual eruptive products (Chapter 2),

b) describe the microearthquake activity local to the TAG active mound seafloor massive sulfide deposit (Chapter 3),

c) better understand from microearthquake observations, the processes of secondary fluid circulation and mineral precipitation within the hydrothermal system (Chapter 3), 
d) assess the relationship between local and regional seismicity and exit fluid venting temperatures at the TAG active mound (Chapter 4).

\subsection{Gakkel Ridge, $85^{\circ} \mathrm{E}$ segment}

The Gakkel Ridge is among the slowest-spreading sections of the global MOR system. The Gakkel Ridge and the Southwest Indian Ridge fall within a unique classification of ridges termed "ultraslow spreading," which are characterized by alternating magmatic and amagmatic segments, and a lack of transform faulting [Cannat et al., 2003; Dick et al., 2003]. Limited seafloor mapping studies have been conducted at ultraslow spreading ridges [e.g., Dick et al., 2003; Standish et al., 2008; Michael et al., 2003; Edwards et al., 2003] and even fewer with observations at the scale of individual eruptions owing to the logistical and technical challenges associated with working in the rough seas of the Southern Ocean (i.e., Southwest Indian Ridge) and under the perennial ice pack of the Arctic Ocean (i.e., Gakkel Ridge), where a large fraction of ultraslow spreading ridges occur. The $1800 \mathrm{~km}$-long Gakkel Ridge extends from near Greenland $\left(12.8 \mathrm{~mm} \mathrm{yr}^{-1}\right.$ full rate) across the Eastern Arctic Basin to near the Siberian margin ( $6.5 \mathrm{~mm} \mathrm{yr}^{-1}$ full rate) [Vogt et al., 1979; DeMets et al., 1994; Sella et al., 2002]. For comparison, the ultraslowspreading Southwest Indian Ridge spreads at rates from 12 to $16 \mathrm{~mm} \mathrm{yr}^{-1}$, although obliquely spreading segments may experience effective spreading rates below $8 \mathrm{~mm} \mathrm{yr}^{-1}$ [DeMets et al., 1994; Dick et al., 2003].

In 1999 the Global Seismic Network detected the largest MOR earthquake swarm in recorded history at $85^{\circ} \mathrm{E}$ [Müller and Jokat, 2000]. Earthquake magnitudes ranged from 3.2 to 5.8 and some events had non-double couple focal mechanisms similar to those of known volcanic events [Korger and Schlindwein, 2011]. The swarm lasted $>7$ months. The SCICEX expedition of the Gakkel Ridge followed the detected seismicity with a sidescan sonar survey and imaged a large region of high backscatter intensity interpreted as unsedimented lava flows [Edwards et al., 2001]. The 2001 AMORE expedition returned to the study area to conduct dredging and water column surveys. The most 
vigorous hydrothermal venting detected along the ridge was found in the same location $\left(85^{\circ} \mathrm{E}\right)$ where a $1400 \mathrm{~m}$ thick megaplume was observed [Edmonds et al., 2003].

Seismoacousitic arrays recorded numerous microearthquakes (average magnitude $=$ -0.33) during the 2001 AMORE study that are proposed to have been magmatic in origin [Schlindwein et al., 2007; Schlindwein and Riedel, 2010]. From this evidence, it was hypothesized that the $85^{\circ} \mathrm{E}$ segment is a hydrothermally and volcanically active area that experienced eruption in 1999.

In Chapter 2, we use samples and images acquired from the site with a purpose-built camera and sampling system (CAMPER) during the AGAVE expedition in 2007 to constrain the modes of volcanic accretion at this remote site, including what appears to be ubiquitous explosive activity during the 1999 earthquake swarm. Imagery revealed that major portions of the axial valley are blanketed with volcaniclastic deposits interpreted to result from magma fragmentation during explosive eruptions [Sohn et al., 2008]. We expand on evidence for magmatically-driven explosive eruptions by using the complete suite of dive images to constrain volcanic processes at the scale of individual lava flows. Pyroclastic eruption in the deep ocean is a topic of controversy because mid-ocean ridge eruptions are generally dominated by effusive eruptions of basalt with low volatile contents. External water is thought to be unable to drive explosive eruptions, especially at these depths due to the lack of boiling. However explosive volcanic deposits have been documented at similarly deep oceanic spreading centers [Clague et al., 2003, 2009] and mechanisms for submarine explosive eruptions have been evaluated in a variety of arc, near-arc, and ocean island settings [Wright, 1994; Clague et al., 2000, 2003, 2009; Chadwick et al., 2008; Schipper et al., 2010; Deardorff et al., 2011; Helo, et al., 2011; Resing et al., 2011]. Our dive imagery demonstrates that the seafloor in this area is covered by small lava flows and volcaniclastic deposits within the large high-backscatter region [Edwards et al., 2003]. We use our dive images to develop a new model for volcanic processes at the $85^{\circ} \mathrm{E}$ segment, and discuss the implications of this model for ultraslow spreading volcanic processes, in general. 
In the future, characterizing the individual lava flows and potential products of pyroclastic eruption will help to answer remaining questions about volcanic processes on deep and ultraslow spreading ridges, such as:

a) How are volcaniclastic materials formed and dispersed during deep-sea eruptions?

b) How are magmatic volatiles sequestered and/or how is magma fragmented?

c) How are effusive and explosive eruptions related?

d) How robust is the relationship between eruption volume and spreading rate?

These questions could potentially be answered by more direct observations of the seafloor on deep ridges. Identifying the boundaries/extent of an individual volcaniclastic eruption product, in particular, may add needed information on the formation and dispersal of clasts.

\subsection{The TAG active mound, Mid-Atlantic Ridge $\left(2^{\circ} 08^{\prime} \mathrm{N}\right)$}

The Trans-Atlantic Geotraverse (TAG) segment on the slow spreading Mid-Atlantic Ridge at $26^{\circ} 08^{\prime} \mathrm{N}$ (half-spreading rates of $13 \mathrm{~mm} \mathrm{year}^{-1}$ to the east and $11 \mathrm{~mm}^{-1}$ year ${ }^{-1}$ to the west) [McGregor and Rona, 1975; McGregor et al., 1977] hosts one of the largest known and best studied hydrothermal systems on the seafloor (e.g., Scott et al., 1974a, 1974b; Rona et al., 1975, 1986; Campbell et al., 1988; Karson and Rona, 1990; Herzig et $a l ., 1998$, etc.) The TAG active mound, a seafloor massive sulfide located on the extensional hanging wall of a detachment fault at $3670 \mathrm{~m}$ depth [Tivey et al., 2003; deMartin et al., 2007], has been the subject of numerous multidisciplinary studies, including segment- and mound-scale multibeam bathymetry and side-scan sonar [Humphris and Kleinrock, 1996; Kleinrock and Humphris, 1996; White et al., 1998; Humphris and Cann, 2000]; geophysical surveys [Evans, 1996; Tivey et al., 2003; Canales et al., 2007; deMartin et al., 2007]; and investigations of rocks and vent fluids from the TAG active mound [Humphris et al., 1995; Tivey et al., 1995; Sohn et al., 2007a,b]. 
Microearthquake, magnetic, and seismic refraction studies on the ridge detected a zone of demagnetization and low-velocity attributed to the extensional environment of a $\sim 5 \mathrm{~km}$ long shallow dipping $\left(20^{\circ}\right)$ dome-shaped detachment fault [Tivey et al., 2003; Canales et al., 2007; deMartin et al., 2007] hosting the TAG hydrothermal field, a zone of lowtemperature alteration and three zones of high-temperature alteration with an assemblage of active and relict hydrothermal mounds up to 50,000 years old [Thompson et al., 1985; Lalou et al., 1990; Rona et al., 1993a,b]. The seismogenic zone of the detachment fault extends to 7-8 km below the seafloor and may serve as a pathway for deep hydrothermal fluid circulation that fuels high temperature venting at the active TAG mound [deMartin et al., 2007]. High temperature activity is currently focused at the TAG active mound, one of at least four large hydrothermal deposits in the field [White et al., 1998].

The TAG active mound is a $200 \mathrm{~m}$ diameter, $50 \mathrm{~m}$ tall massive sulfide deposit that discharges focused hydrothermal fluids in excess of $360^{\circ} \mathrm{C}$ from a Black Smoker Complex (B.S.C.) of sulfide chimneys at the top of the mound and diffuse, lower temperature fluids from many orifices on the mound surface [Campbell et al., 1988; Humphris et al., 1995; Tivey et al., 1995]. Within and beneath the active mound, buoyant high temperature fluids are focused in an $\sim 80 \mathrm{~m}$ wide upflow zone to the Black Smoker Complex [Honnorez et al., 1998]. Relatively cooler fluids derived from entrained seawater that is conductively heated and mixed with black smoker fluids are diffusely vented across the mound. Time scales of flow reversals in exit fluid temperature data and measurements of low conductive heat flow are indicative of seawater entrainment into the mound surface, and occur on complex episodic and periodic time scales [Becker et al., 1996; Sohn, 2007a,b].

In spite of the large body of knowledge on the TAG active mound, some key aspects of the hydrothermal system remain unclear. In particular, relatively little is known about the physical extent and geometry of hydraulic pathways and subsurface fluid flow. Defining the zone of secondary recharge is important to understanding where mineral deposition, 
especially that of anhydrite, occurs within the mound. There is strong evidence from the TAG active mound subsurface that faulting is necessary to maintain shallow hydraulic pathways, and studies on fast spreading mid-ocean ridge systems have shown a direct correlation between fluid flow and local seismicity [Sohn et al., 1998; Johnson et al., 2000; Davis et al., 2004].

In Chapter 3, we investigate hydraulic phenomenon by deploying a dense small aperture array of ocean bottom seismometers in a ring on the periphery of the TAG active mound seafloor massive sulfide. We detected 32,078 microearthquakes in a 9-month deployment. We model the microearthquakes as reaction-driven fracturing events in response to the deposition of anhydrite in the secondary circulation system, and use this model to constrain the rate and subsurface location of anhydrite deposition at the active mound.

In Chapter 4, we use statistical methods to assess the impact of local and regional microearthquake activity on exit-fluid temperatures at the TAG active mound. Regional microearthquakes occur on the detachment fault hosting the TAG hydrothermal field, as well as antithetic normal faults. Local microearthquakes described in Chapter 3, are located in the shallow subsurface $(<125 \mathrm{mbsf})$ directly on the periphery of the TAG active mound, and are thought to be intrinsic to hydrothermal processes. Comparison of microearthquake catalogs with concurrent exit fluid temperature venting records allows us to look for feedbacks that suggest that microearthquake activity affects subsurface permeability and reflects the maintenance of hydraulic pathyways in the hydrothermal system. Results of initial tests suggest that more refined methods may be successful in defining spatial and temporal relationships between subsurface cracking and hydraulic pathways to surface vents. 
In the future, characterizing the precise spatial distribution of subsurface mineralization and the secondary recharge zone on hydrothermal mounds will help to answer several remaining questions about their behavior, such as:

a) How does the subsurface permeability of a seafloor massive sulfide change in time?

b) How broad is the source and depth of seawater entrainment, that triggers a great deal of mineral precipitation, especially that of anhydrite, in the mound?

These questions could potentially be answered by using a more dense, small aperture deployment of seismometers on seafloor hydrothermal systems. Currently few submarine studies of hydrothermal systems exist. Understanding permeability and zones of mineral deposition and recharge are also important to those interested in the subsurface biosphere and thermal structure of the mound.

Examined as a whole, this thesis attempts to contribute to the growing body of work on slow- and ultraslow-spreading mid-ocean ridges and the vast wealth of knowledge and expertise on the TAG active mound and lesser-studied seafloor massive deposits. This progress towards characterizing the volcanic structure of the remote Gakkel Ridge, the ultraslow-spreading end member of our global mid-ocean ridge system, sheds light on many questions about deep-sea explosive volcanism. Studies at the TAG active mound make progress towards the geophysical imaging of sulfide deposits and a better understanding of the short-term hydrothermal processes necessary to build and maintain seafloor massive sulfide deposits. 


\section{References}

Baker, E. T., R. A. Feely, M. J. Mottl, F. T. Sansone, C. G. Wheat, J. A. Resing, and J. E. Lupton (1994), Hydrothermal plumes along the East Pacific Rise, $8^{\circ} 40^{\prime}$ to $11^{\circ} 50^{\prime} \mathrm{N}$ : Plume distribution and relationship to the apparent magmatic budget, EPSL,128, 1-17.

Baker, E. T., H. N. Edmonds, P .J. Michael, W. Bach, H. J. B. Dick, J. E. Snow, S. L. Walker, N. R. Banerjee, and C. H. Langmuir (2004), Hydrothermal venting in magma deserts: The ultraslow-spreading Gakkel and Southwest Indian Ridges, $G$ cubed, 5(8), doi:10.1029/2004GC000712.

Becker, K., R. Von Herzen, J. Kirklin, R. Evans, D. Kadko, M. Kinoshita, O. Matsubayashi, R. Mills, A. Schultz, and P. Rona (1996), Conductive heat flow at the TAG active hydrothermal mound: Results from 1993-1995 submersible surveys, Geophys. Res. Lett., 23, 3463-3466.

Behn, M. D., and G. Ito (2008), Magmatic and tectonic extension at mid-ocean ridges: 1. Controls on fault characteristics, G-cubed, 9(8), doi:10.1029/2008GC001965.

Bown, J. W. and R. S. White (1994), Variation with spreading rate of oceanic crustal thickness and geochemistry, EPSL, 121, 435-449.

Campbell, A. C., M. R. Palmer, G. P. Klinkhammer, T. S. Bowers, J. M. Edmond, J. R. Lawrence, J. F. Casey, G. Thompson, S. Humphris, P. Rona, and J. A. Karson (1988), Chemistry of hot springs on the Mid-Atlantic Ridge, Nature, 335(6), 514519.

Canales, J.P., R. A. Sohn, and B. J. deMartin (2007), Crustal structure of the TransAtlantic Geotraverse (TAG) segment (Mid-Atlantic Ridge, $26^{\circ} 100 \mathrm{~N}$ ):

Implications for the nature of hydrothermal circulation and detachment faulting at slow spreading ridges, Geochem. Geophys. Geosys., 8(Q08004), doi:10.1029/2007GC001629.

Cann, J. R., and D. K. Smith (2005), Evolution of volcanism and faulting in a segment of the Mid-Atlantic Ridge at 25N, G-cubed, 6(9), doi:10.1029/2005GC000954.

Cannat, M., C. Rommevaux-Jestin, and H. Fujimoto (2003), Melt supply variations to a magma-poor ultra-slow spreading ridge (Southwest Indian Ridge $61^{\circ}$ to $69^{\circ} \mathrm{E}$ ), $G$ cubed, 4(8), doi:100.1029/2002GC000480. 
Chadwick, W. W., K. V. Cashman, R. W. Embley, H. Matsumoto, R. P. Dziak, C. E. J. de Ronde, T. K. Lau, N. D. Deardorff, and S. G. Merle (2008), Direct video and hydrophone observations of submarine eruptions at NW Rota-1 volcano, Mariana arc, J. Geophys. Res., 113(B08S10), doi:10.1029/2007JB005215.

Clague, D. A., A. S. Davis, J. L. Bischoff, J. E. Dixon, and R. Geyer (2000), Bubble-wall fragments formed by submarine steam explosions on Loihi Seamount and Kilauea, Volcano. Bull. Volcanol., 61, 437-449.

Clague, D. A., R. Batiza, J. Head, and A. S. Davis (2003), Pyroclastic and hydroclastic deposits on Loihi Seamount, Hawaii, in Explosive Subaqueous Volcanism, AGU Monograph, vol. 140, edited by J. D. L. White, J. L. Smellie, and D. A. Clague, pp. 73-95, AGU, Washington, D. C.

Clague, D. A., J. B. Paduan, and A. S. Davis (2009), Widespread strombolian eruptions of mid-ocean ridge basalt, J. Volcanol. Geotherm. Res., 180, 171-188, doi:10.1016/j.jvolgeores.2008.08.007.

Cochran, J. R. (2008), Seamount volcanism along the Gakkel Ridge, Arctic Ocean, Geophys. J. Int., 174, 1153-1173, doi:10.1111/j.1365-246X.2008.03860.x.

Davis, E., K. Becker, R. Dziak, J. Cassidy, K. Wang, and M. Lilley (2004), Hydrological response to a seafloor spreading episode on the Juan de Fuca ridge, Nature, 430, 335-338.

Deardorff, N. D., K. V. Cashman, and W. W. Chadwick (2011), Observations of eruptive plume dynamics and pyroclastic deposits from submarine explosive eruptions at NW Rota-1, Mariana arc, J. Volcanol. Geotherm. Res., 202, 47-59, doi:10.1016/j.jvolgeores.2011.01.003.

Driesner, T. and S. Geiger (2007), Numerical simulation of multiphase fluid flow in hydrothermal systems, in Fluid-Fluid Interactions, Reviews in Mineralogy and Geochemistry, vol. 65, edited by A. Liebscher and C. A. Heinrich, pp. 187-212.

deMartin, B. J., R. A. Sohn, J. P. Canales, and S. E. Humphris (2007), Kinematics and geometry of active detachment faulting beneath the Trans-Atlantic Geotraverse (TAG) hydrothermal field on the Mid-Atlantic Ridge, Geology, 35, 711-714.

DeMets, C., R. G. Gordon, D. F. Argus, and S. Stein (1994), Current plate motions, Geophys. Res. Lett., 21, 2191-2194.

Dick, H. J. B., J. Lin, and H. Schouten (2003), An ultraslow spreading class of ocean ridge, Nature, 426, 405-412. 
Edmonds, H. N., P. J. Michael, E. T. Baker, D. P. Connelly, J. E. Snow, C. H. Langmuir, J .H. B. Dick, R. Muhe, C. R. German, and D. W. Graham (2003), Discovery of abundant hydrothermal venting on the ultraslow spreading Gakkel ridge in the Arctic Ocean, Nature, 421, 252-256.

Edwards, M. H., G. J. Kurras, M. Tolstoy, D. R. Bohnenstiehl, B. J. Coakley, and J. R. Cochran (2001), Evidence of recent volcanic activity on the ultraslow spreading Gakkel ridge, Nature, 409, 808-812.

Edwards, M. H., and B. J. Coakley (2003), SCICEX Investigations of the Arctic Ocean System, Chem. Erde., 63, 281-328.

Evans, R. L. (1996), A seafloor gravity profile across the TAG hydrothermal mound, Geophys. Res. Lett., 23, 3447-3450.

Fornari, D., M. Tivey, H. Schouten, M. Perfit, D. Yoerger, A. Bradley, M. Edwards, R. Haymon, D. Scheirer, K. Von Damm, T. Shank, and A. Soule (2004), Submarine lava flow emplacement at the East Pacific Rise 950’N: Implications for uppermost ocean crust stratigraphy and hydrothermal fluid circulation, in The Thermal Structure of the Ocean Crust and the Dynamics of Hydrothermal Circulation, AGU Monograph, vol. 148, edited by C. R. German, J. Lin, and L. M. Parson, pp. 187-218, AGU, Washinton, D. C.

German, C.R., and K.L. Von Damm (2004), Hydrothermal processes, in Treatise on geochemistry: The oceans and marine geochemistry, vol. 6, edited by H.D. Holland and K.K. Turekian, pp. 181-222, Elsevier, London.

Hannington, M. D., A. G. Galley, P. M. Herzig, and S. Petersen (1998), Comparison of the TAG mound and stockwork complex with Cyprus-type massive sulfide deposits, in Proceedings of the Ocean Drilling Program, Scientific Results, vol. 158, edited by P. M. Herzig, S. E. Humphris, et al., pp. 231-254, College Station, Texas, Ocean Drilling Program.

Hannington, M.D., C.E.J. de Ronde, and S. Petersen (2005), Sea-floor tectonics and submarine hydrothermal systems, in $100^{\text {th }}$ Anniversary volume of Economic Geology, vol. 100, edited by J. Hedenquist et al., pp. 111-141, Society of Economic Geologists, Littleton, Colorado.

Helo, C., M.-A. Longpre, N. Shimizu, D. A. Clague, and J. Stix (2011), Explosive eruptions at mid-ocean ridges driven by $\mathrm{CO} 2$-rich magmas, Nature Geoscience, 4, 260-263, doi: 10.1038/NGEO1104. 
Herzig, P. M., S. Petersen, M. D. and Hannington (1998), Geochemistry and sulfur isotopic composition of the TAG hydrothermal mound, Mid-Atlantic Ridge, $26^{\circ} \mathrm{N}$, in Proceedings of the Ocean Drilling Program, Scientific Results, vol. 158, edited by P. M. Herzig, S. E. Humphris, et al., pp. 47-40, College Station, Texas, Ocean Drilling Program.

Humphris, S. E., P. M. Herzig, D. J. Miller, et al. (1995), The internal structure of an active sea-floor massive sulphide deposit, Nature, 377, 713-716.

Humphris, S. E., and M. C. Kleinrock (1996), Detailed morphology of the TAG active hydrothermal mound: Insights into its formation and growth, Geophys. Res. Lett., $23,3443-3446$.

Humphris, S.E., and J. R. Cann (2000), Constraints on the energy and chemical balances of the modern TAG and ancient Cyprus seafloor sulfide deposits, J. Geophys. Res., 105, 28477-28488.

Johnson, H. P., M. Hutnak, R. P. Dziak, C. G. Fox, I. Urcuyo, J. P. Cowen, J. Nabelek, C. Fisher (2000), Earthquake-induced changes in a hydrothermal system on the Juan de Fuca mid-ocean ridge, Nature, 407, 174-177.

Karson, J. A., and P. A. Rona (1990), Block-tilting, transfer faults, and structural control of magmatics and hydrothermal processes in the TAG area, Mid- Atlantic Ridge $26^{\circ} \mathrm{N}$, Geological Society of America Bulletin, 102, 1635-1645.

Kleinrock, M. C., and S. E. Humphris (1996), Structural control on seafloor hydrothermal activity at the TAG active mound, Nature, 382, 149-153.

Korger, E. I. M., and V. Schlindwein (2011), Performance of localization algorithms for $\mathrm{t}$ teleseismic mid-ocean ridge earthquakes: the 1999 Gakkel Ridge earthquake swarm and its geological interpretation, Geophys. J. Int., doi: 10.1111/j.1365246X.2011.05282.x.

Lalou, C., G. Thompson, M. Arnold, E. Brichet, E. Druffel, and P. A. Rona (1990), Geochronology of TAG and Snake Pit hydrothermal fields, Mid- Atlantic Ridge: Witness to a long and complex hydrothermal history, Earth Planetary Science Letters, 97, 113-128.

Langmuir, C.H., Klein, E.M., Plank, T. (1992), in: Phipps Morgan, J., Blackman, D.K., Sinton, J.M. (Eds.), Mantle flow and melt generation at mid-ocean ridges. AGU Geophys Monogr., vol. 71, pp. 183-280.

Lister, C. R. B. (1972), On the thermal balance of a midocean ridge, Geophys. J. R. Astron. Soc., 26, 515-535. 
Lowell, R. P., and Y. Yao (2002), Anhydrite precipitation and the extent of hydrothermal recharge zones at ocean ridge crests, J. Geophys. Res., 107(B9), 2182, doi: $10.1029 / 2001 J B 001289$.

Lowell, R. P., Yao, Y., and L. N. Germanovich (2003), Anhydrite precipitation and the relationship between focused and diffuse flow in seafloor hydrothermal systems, J. Geophys. Res., 108(B9), 2424, doi:10.1029/2002JB002371.

Macdonald, K.C. (1982), Mid-Ocean Ridges: Fine scale tectonic, volcanic and hydrothermal processes within the plate boundary zone, Ann. Rev. Earth Planet. Sci., 10, 155-90.

McCaig, A. M., R. A. Cliff, J. Escartin, A. E. Fallick, and C. J. MacLeod (2007), Oceanic detachment faults focus very large volumes of black smoker fluids, Geology, 35(10), 935-938, doi: 10.1130/G23657A.1.

McGregor, B. A., and P. A. Rona (1975), Crest of Mid-Atlantic Ridge at $26^{\circ} \mathrm{N}, J$. Geophys. Res., 80, 3307-3314.

McGregor, B. A., C. G. A. Harrison, J. W. Lavelle, and P. A. Rona (1977), Magnetic anomaly pattern on the Mid-Atlantic Ridge crest at $26^{\circ} \mathrm{N}, J$. Geophys. Res., 82, 231-238.

Michael, P. J., C. H. Langmuir, H. J. B. Dick, J. E. Snow, S. L. Goldstein, D. W. Graham, K. Lehnert, G. Kurras, W. Jokat, R. Mühe, H. N. Edmonds (2003), Magmatism and amagmatic seafloor generation at the ultraslow spreading Gakkel ridge, Arctic Ocean, Nature, 423, 956-961.

Müller, C., and W. Jokat (2000), Seismic evidence for volcanic activity discovered in central Arctic, Eos, 81, 265-269.

Perfit, M. R. and W. W. Chadwick, Jr. (1998), Magmatism at Mid-Ocean Ridges: Constraints from volcanological and geochemical investigations, in Faulting and Magmatism at Mid-Ocean Ridges, Geophysical Monograph, vol. 106, edited by W. R. Buck, T. Delaney, A. Karson, and Y. Lagabrielle, pp. 59-115, AGU, Washington, D. C.

Reid, I., and H. R. Jackson (1981), Oceanic spreading rate and crustal thickness, Marine Geophys. Res., 5, 165-172. 
Resing, J. A., K. H. Rubin, R. W. Embley, J. E. Lupton, E. T. Baker, R. P. Dziak, T. Baumberger, M. D. Lilley, J. A. Hubers, T. M. Shank, D. A. Butterfield, D. A. Clague, N. S. Keller, S. G. Merle, N. J. Buck, P. J. Michael, S. A. Soule, D. W. Caress, S. L.Walker, R. Davis, J. P. Cowen, A.-L. Reysenbach, and H. Thomas (2011), Active submarine eruption of boninite in the northeastern Lau Basin. Nature Geoscience, 4(11), 799-806, doi:10.1038/NGEO1275.

Rona, P. A., B. A. McGregor, P. R. Betzer, G. W. Bolger, and D. C. Krause (1975), Anomalous water temperatures over Mid-Atlantic Ridge crest at $26^{\circ} \mathrm{N}$, Deep Sea Research, 22, 611-618.

Rona, P. A., G. Klinkhammer, T. A. Nelsen, J. H. Trefry, and H. Elderfield (1986), Black smokers, massive sulphides, and vent biota at the Mid-Atlantic Ridge, Nature, $321,33-37$.

Rona, P. A., Y. A. Bogdanov, E. G. Gurvich, A. Rimski-Korsakov, A. M. Sagalevitch, M. D. Hannington, and G. Thompson (1993a), Relict hydrothermal zones in the TAG hydrothermal field, Mid-Atlantic Ridge $26^{\circ} \mathrm{N}, 45^{\circ} \mathrm{W}$, J. Geophys. Res., 98 , 9715-9730.

Rona, P. A., M. D. Hannington, C. V. Raman, G. Thompson, M. K. Tivey, S. E. Humphris, C. Lalou, and S. Petersen (1993b), Active and relict seafloor hydrothermal mineralization at the TAG hydrothermal field, Mid-Atlantic Ridge, Economic Geology, 18, 1989-2017.

Rubin, K. H. and J. M. Sinton (2007), Inferences on mid-ocean ridge thermal and magmatic structure from MORB compositions, EPSL, 260, 257-276, doi:10.1016/j.eps1.2007.05.035.

Schipper, C. I, and J. D. L. White (2010), No depth limit to hydrovolcanic limu o Pele: analysis of limu from Lo'ihi Seamount, Hawai'I, Bull Volcano., 72, 149-164, doi: 10.1007/s00445-009-0315-5.

Schlindwein, V., C. Müller, and W. Jokat (2007), Microseismicity of the ultraslowspreading Gakkel Ridge, Arctic Ocean: A pilot study, Geophys. J. Int., 169, 100112, doi:10.1111/j.1365-246X.2006.03308.x.

Schlindwein, V., and C. Riedel (2010), Location and source mechanism of sound signals at Gakkel ridge, Arctic Ocean: Submarine Strombolian activity in the 1999-2001 volcanic episode, G-cubed, 11, Q01002, doi:10.1029/2009GC002706.

Sclater, J. G., C. Jaupart, and D. Galson (1980), The heat flow through oceanic and continental crust and the heat loss of the Earth, Rev. Geophys., 18, 269-311. 
Scott, R. B., P. A. Rona, and B. A. McGregor (1974a), The TAG hydrothermal field, Nature, 251, 301-302.

Scott, M. R., R. B. Scott, P. A. Rona, L. W. Butler, and A. J. Nalwalk (1974b), Rapidly accumulating manganese deposit from the median valley of the Mid-Atlantic ridge, Geophys. Res. Lett., 1, 355-358.

Searle, R. C., B. J. Murton, K. Achenbach, T. LeBas, M. Tivey, I. Yeo, M. H. Cormier J. Carlut, P. Ferreira, C. Mallows, K. Morris, N. Schroth, P. van Calsteren, and C. Waters (2010), Structure and development of an axial volcanic ridge: MidAtlantic Ridge, $45^{\circ} \mathrm{N}$, EPSL, 299, 228-241, doi:10.1016/j.epsl.2010.09.003.

Sella, G. F., T. H. Dixon, and A. Mao (2002), REVEL: A model for recent plate velocities from space geodesy, J. Geophys. Res., 107, B4, doi:10.1029/2000JB000033.

Sinton, J., E. Bergmanis, K. Rubin, R. Batiza, T. K. P. Gregg, K. Grönvold, K. C. Macdonald, and S. M. White (2002), Volcanic eruptions on mid-ocean ridges: New evidence from the superfast spreading East Pacific Rise, $17^{\circ}-19^{\circ} \mathrm{S}, \mathrm{J}$. Geophys. Res., 108(B6), 2115, doi: 10.1029/2000JB000090.

Sleep, N. H. (1991), Hydrothermal circulation, anhydrite precipitation, and thermal structure at ridge axes, J. Geophys. Res., 96(B2), 2375-2387.

Small, C. (1994), A global analysis of mid-ocean ridge axial topography, Geophys. J. Int., 116, 64-84.

Smith, D. K. and J. R. Cann (1993), Building the crust at the Mid-Atlantic Ridge, Nature, $365,707-715$.

Sohn, R., D. Fornari, K. Von Damm, J. Hildebrand, and S. Webb (1998), Seismic and hydrothermal evidence for a cracking event on the East Pacific Rise crest at $9^{\circ} 50^{\prime} \mathrm{N}$, Nature, 396, 159-161.

Sohn, R. A. (2007a), Stochastic analysis of exit fluid temperature records from the active TAG hydrothermal mound (Mid-Atlantic Ridge, $26^{\circ} \mathrm{N}$ ): 1 . Modes of variability and implications for subsurface flow, J. Geophys. Res., 112: B07101, doi:10.1029/2007JB004435.

Sohn, R. A. (2007b), Stochastic analysis of exit fluid temperature records from the active TAG hydrothermal mound (Mid-Atlantic Ridge, $26^{\circ} \mathrm{N}$ ): 2. Hidden Markov models of flow episodes, J. Geophys. Res., 112: B09102, doi:10.1029/2007JB004961. 
Sohn, R. A., C. Willis, S. Humphris, T. M. Shank, H. Singh, H. N. Edmonds, C. Kunz, U. Hedman, E. Helmke, M. Jakuba, B. Liljebladh, J. Linder, C. Murphy, K.

Nakamura, T. Sato, V. Schlindwein, C. Stranne, M. Tausenfreund, L. Upchurch, P. Winsor, M. Jakobsson, A. Soule (2008), Explosive volcanism on the ultraslow spreading Gakkel Ridge, Arctic Ocean, Nature, 453, 1236-1238, doi:10.1038/nature07075.

Soule, S. A., J. Escartín, and D. J. Fornari (2009), A record of eruption and intrusion at a fast spreading ridge axis: Axial summit trough of the East Pacific Rise at $9-10^{\circ} \mathrm{N}$, G-cubed, 10(10), doi:10.1029/2008GC002354.

Standish, J. J., H. J. Dick, P. J. Michael, W. G. Melson, and T. O'Hearn (2008), MORB generation beneath the ultraslow spreading Southwest Inditan Ridge $\left(9-25^{\circ} \mathrm{E}\right)$ : Major element chemistry and the importance of process versus source, $G$-cubed, 9(5),1525-2027, doi: 10.1029/2008GC001959.

Stein, C. A., and S. Stein (1994), Comparison of plate and asthenospheric flow models for thermal evolution of oceanic lithosphere, Geophys. Res. Lett, 21(8), 709, doi:10.1029/94GL00632.

Strens, M. R., and Cann, J. R. (1986), A fracture-loop thermal balance model of black smoker circulation, Tectonophysics, 122, 307-324.

Thompson, G., M. J. Mottl, and P. A. Rona (1985), Morphology, mineralogy, and chemistry of hydrothermal deposits from the TAG area, $26^{\circ} \mathrm{N}$ Mid-Atlantic Ridge, Chemical Geology, 49, 243-257.

Tivey, M. K., S. E. Humphris, G. Thompson, M. D. Hannington, and P. A. Rona (1995), Deducing patterns of fluid flow and mixing within the active TAG mound using mineralogical and geochemical data, J. Geophys. Res., 100, 12527-12555.

Tivey, M. A., H. Schouten, and M. C. Kleinrock (2003), A near-bottom magnetic survey of the Mid-Atlantic Ridge axis at $26^{\circ} \mathrm{N}$ : Implications for the tectonic evolution of the TAG segment, J. Geophys. Res., 108, 2277, doi:10.1029/2002JB001967.

Tivey, M. K. (2007), Generation of seafloor hydrothermal vent fluids and associated mineral deposits, Oceanography, 20(1), 50-65.

White, S. N., S. E. Humphris, and M. C. Kleinrock (1998), New observations on the distribution of past and present hydrothermal activity in the TAG area of the Mid-

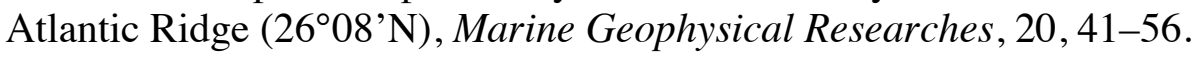

Wright, I. C. (1994), Nature and tectonic setting of the southern Kermadec submarine arc volcanoes: An overview, Marine Geology, 118, 217-236. 
Vogt, P. R., P. T. Taylor, L. C. Kovacs, and G. L. Johnson (1979), Detailed aeromagnetic investigations of the Arctic Basin, J. Geophys. Res., 84, 1071-1089. 


\title{
Chapter 2: Effusive and explosive volcanism on the ultraslow-spreading Gakkel Ridge, $8^{\circ} \mathbf{E}^{*}$
}

\begin{abstract}
We use high-definition seafloor digital imagery and multi-beam bathymetric data acquired during the 2007 Arctic Gakkel Vents Expedition (AGAVE) to evaluate the volcanic characteristics of the $85^{\circ} \mathrm{E}$ segment of the ultraslow spreading Gakkel Ridge (9

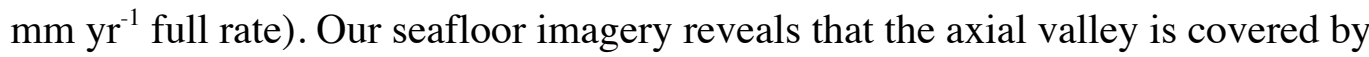
numerous, small-volume (order $\sim 1000 \mathrm{~m}^{3}$ ) lava flows displaying a range of ages and morphologies as well as unconsolidated volcaniclastic deposits with thicknesses up to 10 $\mathrm{cm}$. The valley floor contains two prominent volcanic lineaments made up of axisparallel ridges and small, cratered volcanic cones. The lava flows appear to have erupted from a number of distinct source vents within the $\sim 12-15 \mathrm{~km}$-wide axial valley. Only a few of these flows are fresh enough to have potentially erupted during the 1999 seismic swarm at this site, and these are associated with the Oden and Loke volcanic cones. We model the widespread volcaniclastic deposits we observed on the seafloor as having been generated by the explosive discharge of $\mathrm{CO}_{2}$ that accumulated in (possibly deep) crustal melt reservoirs. The energy released during explosive discharge, combined with the buoyant rise of hot fluid, lofted fragmented clasts of rapidly cooling magma into the water column, and they subsequently settled onto the seafloor as fall deposits surrounding the source vent.
\end{abstract}

\footnotetext{
* Reproduced by permission of American Geophysical Union. Published as: Pontbriand, C. W., S. A. Soule, R. A. Sohn, S. E. Humphris, C. Kunz, H. Singh, K. Nakamura, M. Jakobsson, and T. Shank (2012), Effusive and explosive volcanism on the ultraslowspreading Gakkel Ridge, 85E, Geochemistry, Geophysics, Geosystems, 13(10), 1-22, doi: 10.1029/2012GC004187. Copyright 2012 American Geophysical Union.
} 


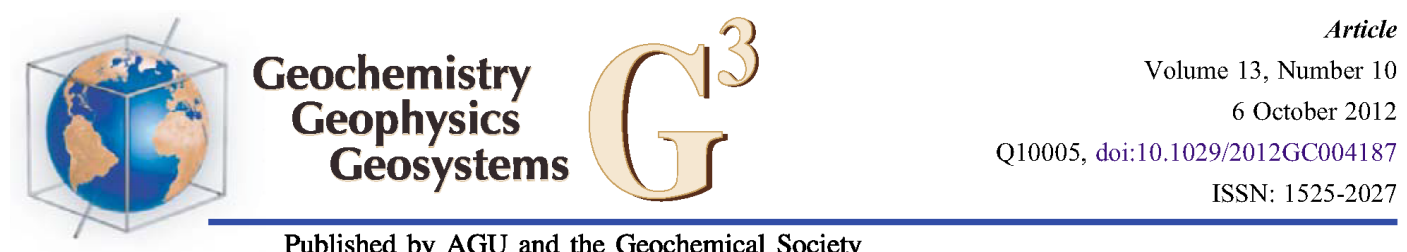

Published by AGU and the Geochemical Society

\title{
Effusive and explosive volcanism on the ultraslow-spreading Gakkel Ridge, $8^{\circ} \mathrm{E}$
}

\author{
Claire W. Pontbriand \\ MIT-WHOI Joint Program in Oceanography, 266 Woods Hole Road, MS 24, Woods Hole, \\ Massachusetts02543,USA (ccwillis@mit.edu)
}

S. Adam Soule, Robert A. Sohn, Susan E. Humphris, Clayton Kunz, and Hanumant Singh Woods Hole Oceanographic Institution, 266 Woods Hole Road, MS 24, Woods Hole, Massachusetts 02543,USA (ssoule@whoi.edu; rsohn@whoi.edu; shumphris@whoi.edu; ckunz@whoi.edu; hsingh@whoi.edu)

\section{Ko-ichi Nakamura}

Institute of Geology and Geoinformation, National Institute of Advanced Industrial Science and Technology, 1-1-1 Higashi, Tsukuba 305-8567, Japan (koichi.nakamura@aist.go.jp)

\section{Martin Jakobsson}

Department of Geological Sciences, Stockbolm University, SE-10691 Stockholm, Sweden (martin.jakobsson@geo.su.se)

\section{Timothy Shank}

Woods Hole Oceanographic Institution, 266 Woods Hole Road, MS 24, Woods Hole, Massachusetts 02543,USA (tshank@whoi.edu)

[1] We use high-definition seafloor digital imagery and multibeam bathymetric data acquired during the 2007 Arctic Gakkel Vents Expedition (AGAVE) to evaluate the volcanic characteristics of the $85^{\circ} \mathrm{E}$ segment of the ultraslow spreading Gakkel Ridge $\left(9 \mathrm{~mm} \mathrm{yr}^{-1}\right.$ full rate). Our seafloor imagery reveals that the axial valley is covered by numerous, small-volume (order $\sim 1000 \mathrm{~m}^{3}$ ) lava flows displaying a range of ages and morphologies as well as unconsolidated volcaniclastic deposits with thicknesses up to $10 \mathrm{~cm}$. The valley floor contains two prominent volcanic lineaments made up of axis-parallel ridges and small, cratered volcanic cones. The lava flows appear to have erupted from a number of distinct source vents within the $\sim 12-15 \mathrm{~km}$-wide axial valley. Only a few of these flows are fresh enough to have potentially erupted during the 1999 seismic swarm at this site, and these are associated with the Oden and Loke volcanic cones. We model the widespread volcaniclastic deposits we observed on the seafloor as having been generated by the explosive discharge of $\mathrm{CO}_{2}$ that accumulated in (possibly deep) crustal melt reservoirs. The energy released during explosive discharge, combined with the buoyant rise of hot fluid, lofted fragmented clasts of rapidly cooling magma into the water column, and they subsequently settled onto the seafloor as fall deposits surrounding the source vent.

Components: 13,400 words, 10 figures.

Keywords: mid-ocean ridge; seafloor morphology; submarine explosive volcanism; ultraslow spreading.

Index Terms: 3035 Marine Geology and Geophysics: Midocean ridge processes; 3045 Marine Geology and Geophysics: Seafloor morphology, geology, and geophysics; 8428 Volcanology: Explosive volcanism (4302). 
Received 13 April 2012; Revised 21 August 2012; Accepted 23 August 2012; Published 6 October 2012.

Pontbriand, C. W., S. A. Soule, R. A. Sohn, S. E. Humphris, C. Kunz, H. Singh, K. Nakamura, M. Jakobsson, and T. Shank (2012), Effusive and explosive volcanism on the ultraslow-spreading Gakkel Ridge, $85^{\circ} \mathrm{E}$, Geochem. Geophys. Geosyst., 13 , Q10005, doi:10.1029/2012GC004187.

\section{Introduction}

[2] Volcanic processes at mid-ocean ridges (MORs) generate the oceanic crust comprising more than $60 \%$ of the Earth's solid surface. Plate spreading rate is perhaps the dominant parameter controlling crustal accretion and volcanic processes at MORs, with faster spreading ridges receiving a higher magma supply rate and exhibiting a hotter thermal structure compared to slower spreading ridges [Macdonald, 1982; Smith and Cann, 1993; Perfit and Chadwick, 1998; Edwards et al., 2001; Sinton et al., 2002; Cann and Smith, 2005; Cochran, 2008; Searle et al., 2010]. Although the first-order effects of spreading rate on ridge morphology (e.g., axial rise versus rift valley) and thermal structure are well-established [Sinton and Detrich, 1992; Smith and Cann, 1993; Small, 1994; Fornari et al., 2004; Cann and Smith, 2005; Rubin and Sinton, 2007; Behn and Ito, 2008; Soule et al., 2009], the implications for volcanic eruption processes (e.g., volume, spatial extent, frequency, effusion rate, and lava composition) are not fully understood. Many seafloor-mapping studies have constrained the nature of volcanic processes across the global MOR system [e.g., Ballard and van Andel, 1977; Bonatti and Harrison, 1988; Perfit and Chadwick, 1998; Sinton et al., 2002; Baker et al., 2004; Soule et al., 2005, 2007], however, volcanic processes at the most slowly diverging plate boundaries are poorly constrained. Limited seafloor-mapping studies have been conducted at ultraslow spreading ridges [e.g., Edwards et al., 2001; Dick et al., 2003; Edwards and Coakley, 2003; Michael et al., 2003; Standish et al., 2008] and even fewer with observations at the scale of individual eruptions owing to the logistical and technical challenges associated with working in the rough seas of the Southern Ocean (i.e., Southwest Indian Ridge) and under the perennial ice pack of the Arctic Ocean (i.e., Gakkel Ridge), where a large fraction of ultraslow-spreading ridges occur.

[3] The Gakkel Ridge exhibits full spreading rates that systematically decrease from $12.8 \mathrm{~mm} \mathrm{yr}^{1}$ at its western end (near Greenland) to $6.5 \mathrm{~mm} \mathrm{yr}^{1}$ at its eastern end (the Siberian margin) [Vogt et al.,
1979; DeMets et al., 1994; Sella et al., 2002]. The latter are the slowest MOR spreading rates found on Earth. Melting models of MORs predict a sharp decrease in magma production and crustal thickness when full spreading rates are lower than $\sim 20 \mathrm{~mm} \mathrm{yr}^{1}$ [Reid and Jackson, 1981; Bown and White, 1994], suggesting that magma supply should be reduced along the entire $1800 \mathrm{~km}$ length of the ridge. Bathymetric surveys and dredging studies conducted during the AMORE expedition [Dick et al., 2003; Michael et al., 2003], along with geophysical surveys [Coakley and Cochran, 1998; Jokat et al., 2003], have demonstrated that the igneous crust does become 'vanishingly thin' in some places, presumably because relatively low and intermittent magma supply rates lead to avolcanic extension and exhumation of ultra-mafic lithologies [Smith and Cann, 1993; Sinton and Detrich, 1992; Cannat, 1996; Dick et al., 2003; Cann and Smith, 2005; Rubin and Sinton, 2007; Behn and Ito, 2008]. However, the ridge exhibits significant along-axis variations in magma supply, and some segments appear to be magmatically robust with crustal thicknesses up to $2 \mathrm{~km}$ greater than at nearby avolcanic segments [Jokat and Schmidt-Aursch, 2007]. These results indicate that the relationship between spreading rate and magma supply is not systematic on the scale of individual ridge segments, and that volcanic processes are highly heterogeneous at ultraslow spreading rates.

[4] Spreading rates along the global MOR system range from ultrafast $\left(>160 \mathrm{~mm} \mathrm{yr}^{1}\right.$, full rate) to ultraslow ( $<12 \mathrm{~mm} \mathrm{yr}^{1}$ ). Fast spreading ridges are believed to experience frequent (order 10-100 years), small-volume, volcanic eruptions along a narrow, axial neovolcanic zone that reflect a relatively high magma supply rate [e.g., Macdonald, 1982; Perfit and Chadwick, 1998; Sinton et al., 2002; Soule et al., 2007]. Morphologically, fast spreading ridges exhibit an axial high with a narrow, semi-continuous, graben [Small, 1994; Fornari et al., 2004; Soule et al., 2009]. By contrast, at slow-spreading ridges the dominant morphologic feature is a rift valley, which is believed to reflect relatively low and intermittent magma supply rates combined with increased tectonic crustal extension [Smith and Cann, 1993; 
Sinton and Detrich, 1992; Cann and Smith, 2005; Rubin and Sinton, 2007; Behn and Ito, 2008]. Volcanic eruptions at slow spreading ridges are thought to be infrequent (order 1000-10,000 years), and to produce discrete, point-source volcanic constructions across the rift valley floor [Smith and Cann, 1993; Cann and Smith, 2005; Cochran, 2008; Searle et al., 2010].

[5] Given the rift valley morphology and intermittent and likely reduced magma supply for volcanic processes at ultraslow-spreading ridges, magma chambers are thought to lie beneath thicker, stronger, lithospheric lids, and therefore require larger magma pressures to induce eruption. Thus it has been hypothesized that ultraslow spreading ridges experience large $\left(1-10 \mathrm{~km}^{3}\right.$ ) and infrequent (order $10,000-100,000$ years) volcanic eruptions and, more generally, that eruption volume scales inversely with spreading rate [Perfit and Chadwick, 1998; Sinton et al., 2002]. Recently the deep-submergence technology to allow for direct visual observations of the Gakkel Ridge and detailed mapping of lava flows beneath the perennial pack ice has made it possible to test these hypotheses. In 2007 the AGAVE expedition utilized a novel vehicle (CAMPER) to acquire high-definition digital imagery and precisely located rock samples from the Gakkel Ridge at the $7^{\circ} \mathrm{E}$ and $85^{\circ} \mathrm{E}$ sites beneath the pack ice. Initial results from the $85^{\circ} \mathrm{E}$ site demonstrated that large portions of the seafloor in this area are blanketed with pyroclastic material from explosive eruptions [Sohn et al., 2008]. We expand on this result by using the complete suite of dive images to constrain volcanic processes at the scale of individual lava flows. Our dive imagery demonstrates that the seafloor in this area is covered by a large number of small lava flows, as opposed to a single, large-volume flow, which is at odds the hypothesis that eruption volume varies inversely with spreading rate [Perfit and Chadwick, 1998; Sinton et al., 2002]. We use our dive images to develop a new model for volcanic processes at the $85^{\circ} \mathrm{E}$ segment, and discuss the implications of this model for ultraslow-spreading volcanic processes, in general.

\section{Gakkel Ridge and the $85^{\circ} \mathrm{E}$ Site}

[6] Dredging studies along the Gakkel Ridge have recovered a mix of ultramafic and mafic lithologies reflecting spatial and temporal variations in magma supply [Dick et al., 2003; Michael et al., 2003]. Dredging from the AMORE expedition in 2001 led to the division of the Gakkel Ridge into three distinct tectono-magmatic provinces: the Western Volcanic Zone (WVZ) from $7^{\circ} \mathrm{W}$ to $3^{\circ} \mathrm{E}$, the Sparsely Magmatic Zone (SMZ) from $3^{\circ}$ to $29^{\circ} \mathrm{E}$, and the Eastern Volcanic Zone (EVZ) from $29^{\circ}$ to $96^{\circ} \mathrm{E}$ [Michael et al., 2003] (Figure 1a). The AMORE expedition dredged almost exclusively basalt lithologies from within the axial valley of the Western Volcanic Zone, and aeromagnetic studies revealed a continuous magnetic anomaly along the rift valley [Jokat and Schmidt-Aursch, 2007], consistent with sustained volcanic accretion for the past at least 25 Myr [Jokat et al., 2003]. By contrast, dredges acquired from the Sparsely Magmatic Zone contained a mixture of basalt and peridotite lithologies, indicating that in some places the magma supply is insufficient to sustain volcanic accretion, leading to the exhumation of peridotite lithologies by extensional faulting. This hypothesis is consistent with large free-water gravity anomalies $(85-150 \mathrm{mGal})$ observed over the ridge axis in this zone [Coakley and Cochran, 1998]. Along the Eastern Volcanic Zone the ridge appears to consist of at least seven widely spaced $(\sim 30 \mathrm{~km})$ volcanic centers. The average depth of the axial valley of the Gakkel Ridge $(4600 \mathrm{~m}$ to $5100 \mathrm{~m})$ is deeper than those of the Mid-Atlantic Ridge (3500-4000 m) and South West Indian Ridge (3090-4730 m) (Figure 2) [Le Douaran and Francheteau, 1981; Sempéré et al., 1990, 1993; Neumann and Forsyth, 1993; Cannat et al., 1999]. At the easternmost end of the ridge the axial valley becomes buried in sediments from the Siberian margin, and gravity data suggest the crust becomes 'vanishingly' thin [Coakley and Cochran, 1998].

[7] The $85^{\circ} \mathrm{E}$ segment of the Gakkel Ridge is of particular interest because in 1999 it hosted the largest earthquake swarm detected to-date by the Global Seismic Network on the spreading axis of a MOR [Müller and Jokat, 2000; Tolstoy et al., 2001]. Two hundred and fifty two earthquakes with magnitudes ranging from 3.2 to 5.8 were detected during a seven-month swarm, and many events during the first few months exhibited non-double couple focal mechanism solutions, which are believed to indicate volcanic activity [Müller and Jokat, 2000; Tolstoy et al., 2001; Korger and Schlindwein, 2012]. Geophysical surveys of the $85^{\circ} \mathrm{E}$ segment from a nuclear submarine (SCICEX expedition) following the onset of the swarm (summer of 1999) imaged a large region of high acoustic backscatter covering the entire axial valley (Figure 3 ), which was interpreted to represent multiple unsedimented, voluminous lava flows [Edwards et al., 2001]. The AMORE 


\section{A.}

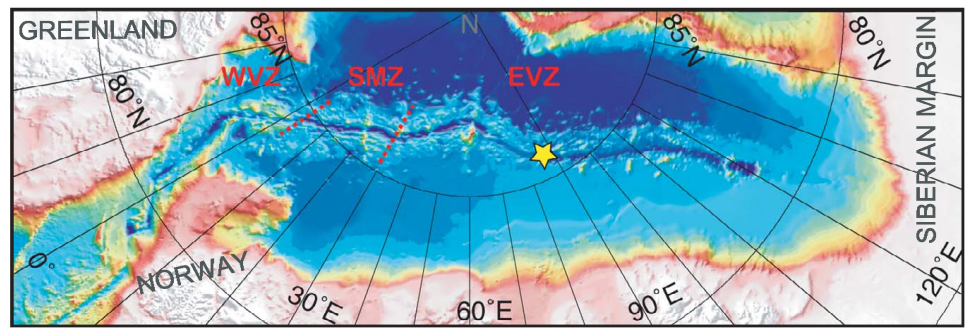

B.

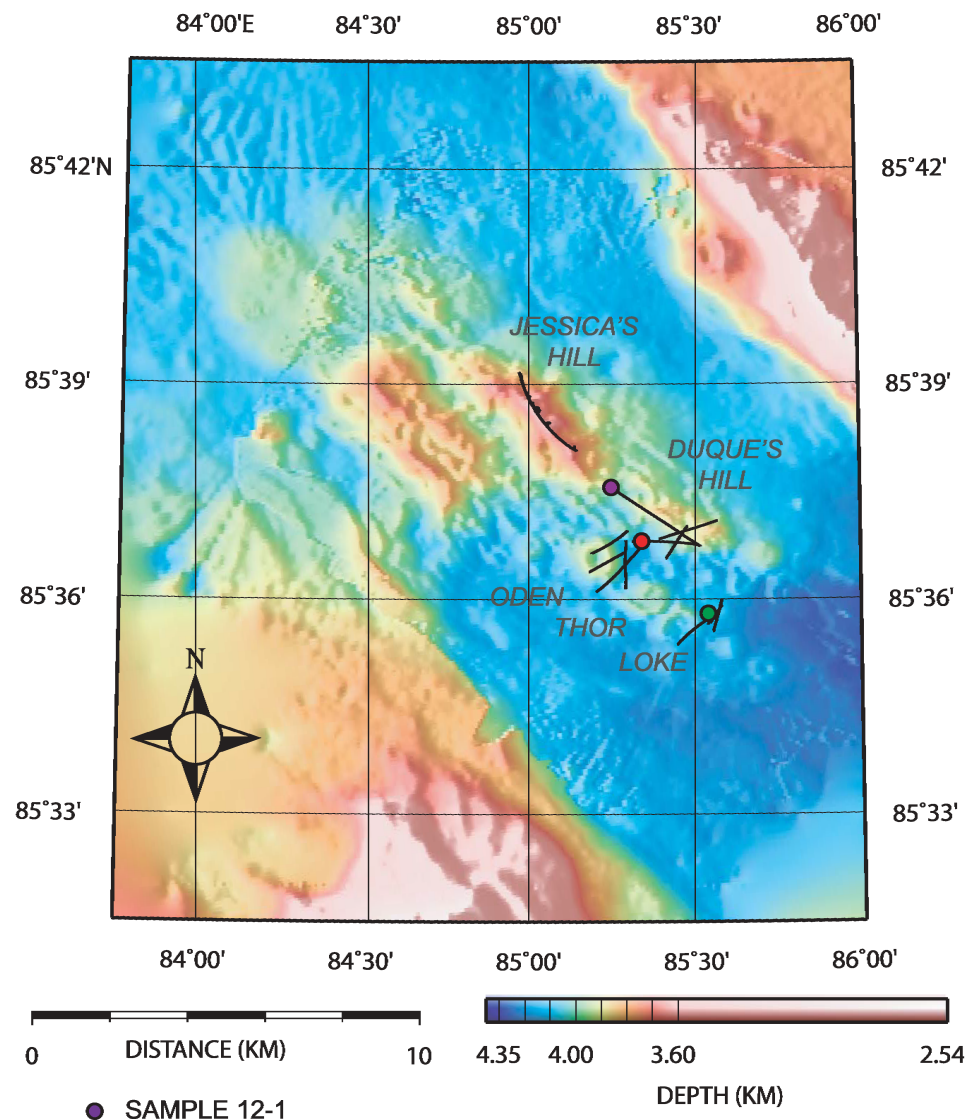

- SAMPLE 13-1

- FIGURE 6

Figure 1. Study Area at $85^{\circ} \mathrm{E}$, Gakkel Ridge. (a) The Gakkel Ridge extends $1800 \mathrm{~km}$ across the Arctic Basin. A star denotes our study area within the Eastern Volcanic Zone (EVZ). (b) A bathymetric chart of the axial valley of the Gakkel Ridge at $85^{\circ} \mathrm{E}$. Depths range from $2543 \mathrm{~m}$ at the rift valley walls to $4351 \mathrm{~m}$ on the axial valley floor. Axial ridges and volcanic cones lie on two axis-parallel lineations of focused volcanism in the center of the rift valley. Black tracks denote the paths of near-seafloor CAMPER vehicle deployments. Circles denote the locations of samples of volcaniclastic deposits and the Figure 6 mosaic.

expedition, which returned to the $85^{\circ} \mathrm{E}$ site in 2001 , found evidence for a hydrothermal 'megaplume' in the water column over the axial valley [Edmonds et $a l ., 2003]$ and seismometers deployed on ice floes over the site recorded explosive reports interpreted to represent ongoing volcanic activity [Schlindwein et al., 2007; Schlindwein and Riedel, 2010]. All of this evidence led to the hypothesis that the $85^{\circ} \mathrm{E}$ 


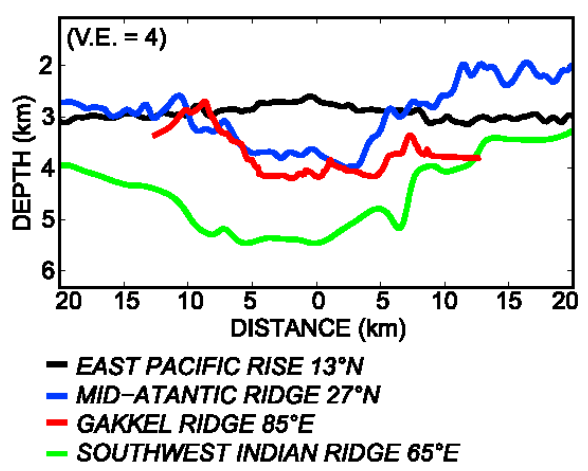

Figure 2. Profiles of the fast spreading (East Pacific Rise), slow spreading (Mid-Atlantic Ridge), and ultraslowspreading ridges (Southwest Indian Ridge, Gakkel Ridge) show how axial morphology and depth vary with spreading rate.

segment has been undergoing a phase of active volcanism wherein it has produced frequent and voluminous lava flows and vigorous, sustained, hydrothermal discharge [Müller and Jokat, 2000; Edwards et al., 2001; Tolstoy et al., 2001; Edmonds et al., 2003; Baker et al., 2004].

[8] The AGAVE expedition returned to the $85^{\circ} \mathrm{E}$ site in 2007 with a towed camera and sampling system (CAMPER) capable of returning highdefinition video and still imagery of the seafloor beneath the ice cap. This imagery revealed that major portions of the axial valley are blanketed with volcaniclastic deposits interpreted to result from magma fragmentation during explosive eruptions [Sohn et al., 2008]. The fragmentation mechanism for the volcaniclasts is enigmatic because: (a) mid-ocean ridge basalts typically exhibit volatile contents well below what is necessary for magmatic fragmentation [Wright, 1994; Clague et al., 2000; Head and Wilson, 2003], (b) hydrostatic pressures on the axial valley floor at an average depth of $3870 \mathrm{~m}$ are well above the critical point for steam formation, which appears to rule out hydrovolcanic fragmentation (i.e., interaction with seawater) [Driesner and Geiger, 2007], and (c) fragmentation due to cooling (quench granulation) is inconsistent with the seafloor distribution and morphology of the clasts. These considerations led Sohn et al. [2008] to propose that the volcaniclastic material was fragmented by magmatic volatiles (e.g., $\mathrm{CO}_{2}$ ) sequestered in large crustal melt bodies. Melt inclusions trapped in volcaniclastic glasses recorded high $\mathrm{CO}_{2}$ concentrations (167-1596 ppm) consistent with entrapment of
$\mathrm{CO}_{2}$ saturated magma at depths $>9 \mathrm{~km}$ in the crust [Shaw et al., 2010]. Similar interpretations have also been suggested for volcaniclastic deposits at other deep oceanic spreading centers [Clague et al., 2003, 2009] and these are among a growing number of observations attributing fragmentation to magmatic volatiles in submarine volcanic systems [Wright, 1994; Clague et al., 2000, 2003, 2009; Chadwick et al., 2008; Schipper and White, 2010; Deardorff et al., 2011; Helo, et al., 2011; Resing et al., 2011].

\section{Data and Methods}

\subsection{Bathymetry}

[9] In 2007 we conducted a bathymetric survey of the axial valley and northern rift valley wall of the $85^{\circ} \mathrm{E}$ volcanic center using I/B Oden's Kongsberg EM $1201^{\circ} \times 1^{\circ}$ multibeam sonar. Bathymetric data were collected while the ship drifted in the pack ice (with engines silent) along overlapping tracks at the $85^{\circ} \mathrm{E}$ segment. The resulting lownoise, high-density multibeam soundings allowed us to construct a $30 \mathrm{~m}$ resolution bathymetric grid of the study area (Figure 1b). This new bathymetric grid was merged with the International Bathymetric Chart of the Arctic Ocean (IBCAO) Version 2.0

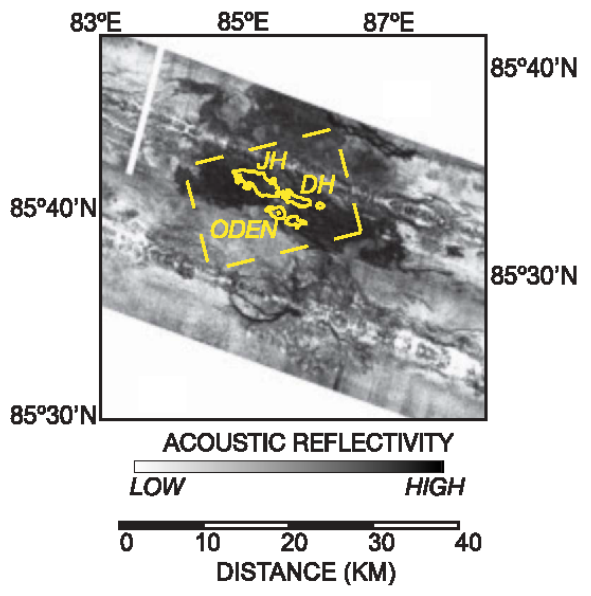

Figure 3. SCICEX 1999 acoustic reflectivity map. A SCICEX 1999 acoustic reflectivity map that encompasses our study area (yellow box) shows an $\sim 30 \mathrm{~km}$ long region of high reflectivity [Edwards et al., 2001]. Our study area, including Jessica's Hill (JH), Duque's Hill (DH), Oden Volcano, and Loke Volcano fall within the zone of high reflectivity. 
[Jakobsson et al., 2008]. IBCAO 2.0 was in turn compiled using all available bathymetric data in the Arctic Ocean at the time of compilation, including soundings collected in the Gakkel Ridge area during the SCICEX 1999 and AMORE cruises. These data are available through Marine Geoscience Data System, the NOAA IBCAO website, and at http:// oden.geo.su.se/AGAVE2007.php [Jakobsson et al., 2008; Ryan et al., 2009].

\subsection{Seafloor Imagery, Seawater Measurements, and Rock Samples}

[10] Near-bottom imaging surveys were conducted with the deep-towed CAMPER vehicle, a towed, fiber-optic vehicle that operates at altitudes of 1.5 to $3 \mathrm{~m}$ above the seafloor. The CAMPER vehicle collected digital video and still imagery, measurements of near-bottom water properties, and geologic and biological samples on thirteen deployments at the $85^{\circ} \mathrm{E}$ site (Figure $1 \mathrm{~b}$ ). Because the vehicle is operated from an idle ship within the pack ice, its trajectory over the bottom is controlled by the direction and flow of the local ice pack, with typical drift speeds of 0.15 to 0.3 knots. The position of CAMPER on the seafloor was determined from ship GPS navigation, corrected for ship heading, and assuming an essentially vertical wire from the ship to the towed vehicle [cf. Stranne et al., 2010].

[11] The multipurpose vehicle was outfitted with five standard and high-definition video cameras that streamed real-time video to the ship via a fiber-optic cable. Conductivity-Temperature-Depth (CTD) and an $E h$ sensor for measuring the oxidation-reduction potential of seawater were also mounted on the vehicle in order to identify the presence of reduced (i.e., fresh) hydrothermal fluids. The $E h$ values presented in this paper are the measured Pt electrode voltage against the $\mathrm{Ag} / \mathrm{AgCl}$ reference electrode in saturated $\mathrm{KCl}$ solution. Eh measurements can be converted to the redox potential of seawater, i.e., against the standard or normal hydrogen electrode (SHE or NHE) by applying a temperature correction, but we do not make the conversion because the electrodes on the moving CAMPER platform never reach equilibrium with seawater [Nakamura et al., 2000]. Measured thermal anomalies represent potential temperature anomalies derived from absolute temperature, pressure and salinity measurements adjusted for an adiabatic displacement to a reference pressure of 3000 dbars [Bryden, 1973; Fofonoff and Millard, 1983; Baker et al., 1994]. Approximately $4 \mathrm{~kg}$ of unconsolidated volcaniclastic deposits, Sample 12-1 and Sample 13-1, were sampled from two sites on the axial valley seafloor at $4000 \mathrm{~m}$ and $4116 \mathrm{~m}$ water depths respectively using a suction sampler on CAMPER (Figure 1b). Larger rock samples were also grabbed from 7 locations [Shaw et al., 2010].

\subsection{Volcanic Deposits at the $85^{\circ} \mathrm{E}$ Site}

[12] We logged seafloor volcanic, tectonic, and biological features in approximately $55 \mathrm{~h}$ of HD seafloor footage over 17.5 linear kilometers of seafloor co-registered with high-resolution bathymetric data $(\sim 5 \mathrm{~km} \times 10 \mathrm{~km}$ area, Figure 1b). Observations were made in seven primary categories, each with multiple subcategories: lava surface morphology, coloration, ornamentation, broken/intact lava surfaces, volcaniclastic deposit thickness, microbial mat coverage, and presence/absence of macrobiology (Figures S1-S7 in the auxiliary material). ${ }^{1}$ These observations allowed us to identify lava flow contacts and flow directions, relative eruption ages, possible source vents, and relationships between volcanic processes, hydrothermal discharge, and biological colonization.

[13] We categorized lava surface morphologies as pillow, lobate, or sheet flow [e.g., Ballard et al., 1975, 1979; Lonsdale, 1977a, 1977b; Bonatti and Harrison, 1988; Fundis et al., 2010], which are thought to reflect increasing volume flux [Fink and Griffiths, 1992; Gregg and Fink, 1995]. In addition, we logged the orientation of lineations, folds, or pillow/lobate elongation, which can be related to the direction of lava transport [e.g., Chadwick et al., 2001; Garry et al., 2006]. We logged lava colorations (black/glassy versus orange/oxidized), and the presence or lack of ornamentation (delicate fingers or buds), as indicators of relative age. We did not detect any pelagic sediment, which is commonly used as an indicator of relative lava age in midocean ridge environments [e.g., Cann and Smith, 2005], in our study area. Low biological productivity beneath the sea ice limits sedimentation rates but pelagic sediment has been observed in the region [Vogt et al., 1979; Thiede et al., 1990]. Recent volcanism may overprint pelagic sediments.

[14] We categorized volcaniclastic deposit coverage, which was present in all imagery, as light, medium, or thick. 'Light' coverage represents lava surfaces that are visible through a light "dusting" of volcaniclastic material. 'Medium' coverage represents surfaces that are not visible through the

\footnotetext{
${ }^{1}$ Auxiliary materials are available in the HTML. doi:10.1029/ 2012GC004187.
} 
volcaniclastic material, with a deposit thickness of a few centimeters. 'Thick' coverage represents surfaces where volcaniclasts pile on lava surfaces with a thickness of up to $\sim 10 \mathrm{~cm}$, and fill in void spaces between seafloor features with tens of centimeters of relief. Potential controls on submarine volcaniclastic deposit thickness include the age of the underlying surface and the proximity to the source regions [e.g., Barreyre et al., 2011]. Volcaniclastic material was sampled from two sites (Figure 1b), as described in section 4.2.2.

[15] We logged the presence or absence of biological organisms and whether the observed organisms are motile or sessile. Sessile organisms, which are fixed to the seafloor, included sponges and anemones. The presence or absence of microbial mats was also logged. Motile organisms, which are free to move to available food sources, include fish, an octopus, shrimp, and amphipods. The presence of sessile organisms provides some indication of relative seafloor (i.e., eruption) age because it is set to zero when a surface is repaved during an eruption, and grows over time as an area is colonized [Shank et al., 1998]. The presence of microbial mats can be used as a proxy for identifying zones of active hydrothermal discharge because these organisms derive metabolic energy by oxidizing hydrothermal fluids [Helmke et al., 2007].

\section{Results}

\subsection{Seafloor Geology}

[16] The $85^{\circ} \mathrm{E}$ segment of the Gakkel Ridge has a $12-15 \mathrm{~km}$ wide and $1.8 \mathrm{~km}$ deep rift valley morphology with an average valley floor depth of $3870 \mathrm{~m}$, and a maximum depth of $4351 \mathrm{~m}$. Linear volcanic ridges and cones (many of which have large central craters) are the predominant constructional volcanic features inside the axial valley and rise several hundred meters above the valley floor. These features are concentrated along two axisparallel lineaments located in the central portion $(5 \mathrm{~km})$ of the axial valley, with the notable exception of a large ( $1250 \mathrm{~m}$ diameter) cone located on an apparent fault terrace about halfway up the northern rift valley wall (Figure 1b). Only 12 faults and fissures are observed along 20 linear $\mathrm{km}$ of track (Figure 7). No peridotite lithologies are observed on the seafloor.

[17] The near-bottom CAMPER transects provide coverage over portions of the two intravalley volcanic lineaments, including Oden and Loke volcanic cones and Jessica's Hill and Duque's Hill volcanic ridges. Oden and Loke are located on the southern lineament; Jessica's Hill and Duque's Hill are located on the northern lineament (the lineaments are offset by $2-3 \mathrm{~km}$, Figure $1 \mathrm{~b}$ ). The lava morphology (lobate vs sheet), coloration (orange/ altered vs glassy), and volcaniclastic deposit thickness observed along the CAMPER tracklines are shown in Figure 4. Talus and pillow lavas are the dominant deposit types observed in the study area. Pillow lavas are observed along $44 \%$ of the trackline. Some lobate and sheet flows are observed on the volcanoes ( $14 \%$ of the trackline) and ridgelines $(<1 \%)$ (Figures $\mathrm{S} 1-\mathrm{S} 7$ in the auxiliary material). Observations of glassy (i.e., young) lavas are restricted to the Oden and Loke Volcanoes, where higher effusion rate sheet flows are also found. The linear ridges appear to be older volcanic features consisting largely of oxidized and broken pillow basalts. Seafloor talus blocks cover the steep slopes and the bases of fault scarps. Glassy, unconsolidated, volcaniclastic material was observed on all surfaces regardless of apparent age or morphology ( $96 \%$ of trackline). Volcaniclastic deposits are thickest on the Duque's Hill and Jessica's Hill linear ridges, thinnest on the Oden and Loke volcanic cones, and are present as a light 'dusting' on the youngest (i.e., glassy) lavas. Microbial mats are observed over $5.5 \%$ of the trackline.

\subsubsection{Oden Volcanic Cone}

[18] Oden is one of several volcanic cones (including Loke and Thor) that constitute the SE end of the southern volcanic lineament (Figure 1b). Three of the CAMPER deployments pass over the Oden volcanic cone, and a fourth passes just to the east (Figure 1b), providing some of the densest track line coverage in our survey area. The flattopped cone is $1400 \mathrm{~m}$ in diameter and $170 \mathrm{~m}$ tall, with a $600 \mathrm{~m}$ wide by $70 \mathrm{~m}$ deep central crater (Figure 5). Our deployments pass over the edges of the crater, and orange-yellow microbial mats blanket much of the seafloor in this area (Figure 5c). Where visible, the seafloor within the crater is covered with talus blocks and a thin $(<1 \mathrm{~cm})$ coating of glassy volcaniclastic material (Figure $5 \mathrm{~d}$ ).

[19] On the crater rim we observe mostly pillow lavas and lobate flows, including obvious contacts between older flows and fresh, glassy surfaces (Figures 5e and 5f). Some of the lavas with orange, altered, surface colorations have retained delicate ornamentations, suggesting that coloration does not necessarily correlate with eruption age. We also observed a glassy, ropy sheet flow with a flow 


\section{A. LOBATE ( $\bullet$ AND SHEET FLOWS ( $\bullet$}

$85^{\circ} 39^{\prime} \mathrm{N}$

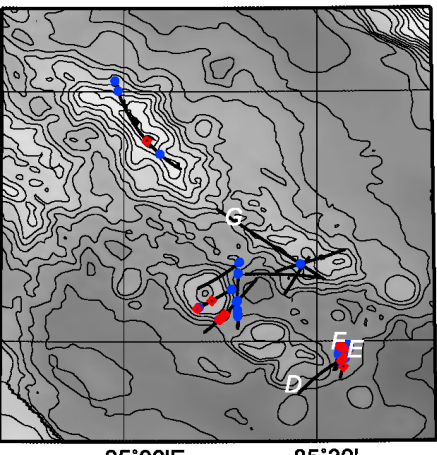

$85^{\circ} 00^{\prime} \mathrm{E}$

B. PILLOW LAVAS - ALTERED (•)/ GLASSY $(\bullet)$
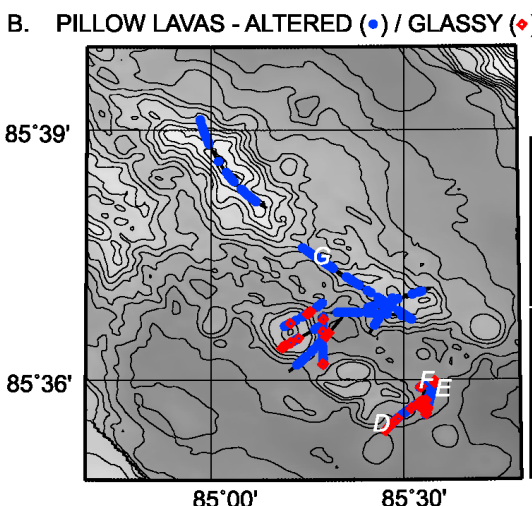

C. VOLCANICLASTIC DEPOSIT THICKNESS

$85^{\circ} 39^{\prime}$

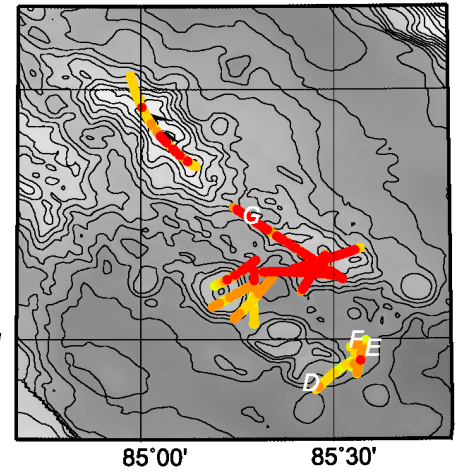

$D E F G$

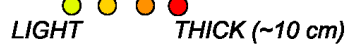

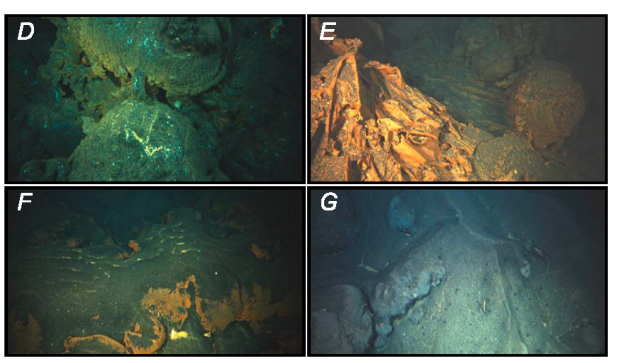

Figure 4. Distributions of lavas and volcaniclasts. (a) A bathymetric map shows that lobate flows (dots) are observed on all four seafloor features examined in digital imagery. Lobate flows (e.g., Figure $4 f$ ) are found at the ridge crests of Jessica's Hill and Duque's Hill axial volcanic ridges. They are also abundant on Oden Volcano and the northern apron of Loke Volcano. Sheet flows (diamonds; e.g., Figure 4e), products of more effusive eruptions, are also abundant on the volcanic cones. (b) Oxidized or weathered pillow flows (dots) are observed on all seafloor features, as well as the seafloor in the depression between the two axial valley trends. Glassy, fresh, and highly ornamented lavas (diamonds; e.g., Figure 4d) are only observed on the steep slopes and summits of Oden and Loke Volcanos and represent the youngest eruptive products in the study area. (c) Volcaniclastic deposits of variable thickness are observed throughout the study. (d-g) Coverage from a light dusting to a thick cover $(\sim 10 \mathrm{~cm})$ that buries lava surfaces and fills in crevices between rocks on the seafloor. Duque's Hill has the thickest volcaniclastic cover. "Fresh" lavas on Oden and Loke Volcanoes are lightly dusted with volcaniclastic material.

orientation radial to the center of the volcano on the crater rim.

[20] The outer walls of the cone consist largely of pillow tubes elongated in the downslope direction, lobate flows, and talus. In some places the pillow tubes are glassy and ornamented, in other places they have orange surfaces. The talus slope on the NE wall is interrupted by an orange-stained lobate flow (with a thin microbial coating). The abrupt nature of this contact and the lack of talus on the lobate flow indicates that the flow is a relatively young feature that erupted from within the talus field.
[21] The marginal regions around Oden exhibit a mix of orange-stained flows and fresh, glassy lavas. The $4000 \mathrm{~m}$ deep bathymetric saddle between Oden and Duque's Hill contains weathered, unornamented, pillow lavas and talus breccia, with no evidence of recent volcanic activity. On the $4100 \mathrm{~m}$ deep platform between Oden and Thor we observe pillow lavas and an ornamented, orange-stained, lobate flow. Glassy, elongate, ornamented pillow lavas were observed at the base of the Thor volcanic cone. 
A.

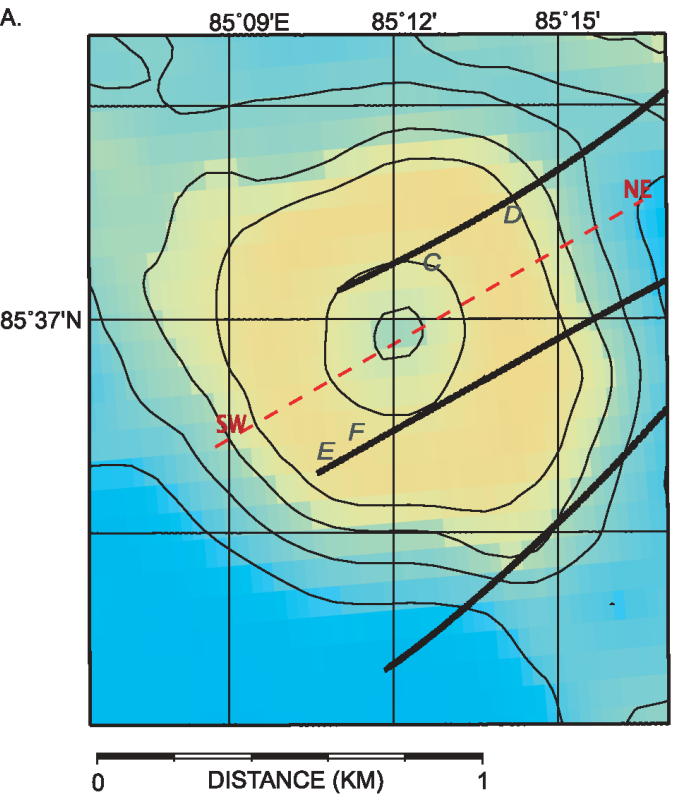

B.
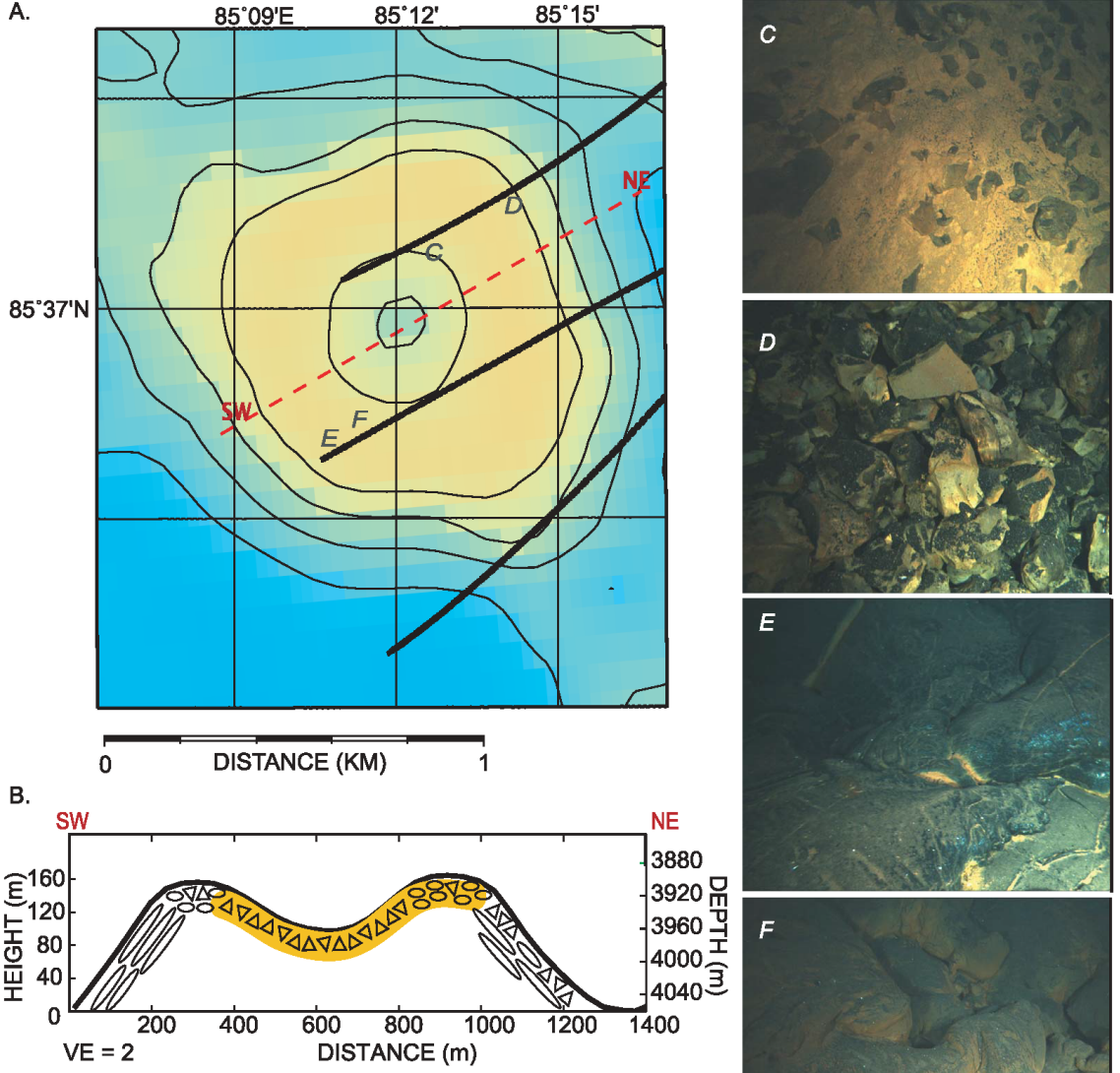

E
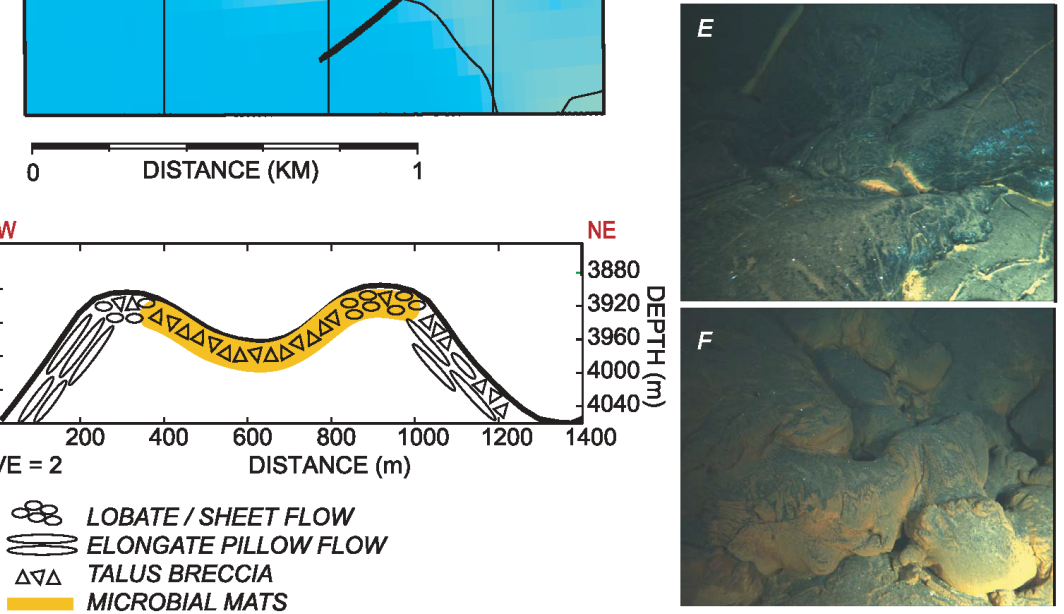

Figure 5. (a) Oden Volcano Map view and (b) profile of Oden Volcano—a $1600 \mathrm{~m}$ diameter volcano with $\sim 200 \mathrm{~m}$ of relief and an $80 \mathrm{~m}$ deep $\times 700 \mathrm{~m}$ wide circular crater. (c) Talus and microbial mats in the crater. (d) Talus ejecta on the flank of the volcano covered in a moderate thickness of large pyroclasts. (e) Fresh, glassy lobate flow with evidence of hydrothermal alteration at edges. (f) Weathered, elongate pillow flow with moderate pyroclastic coverage.

\subsubsection{Loke Volcanic Cone}

[22] The Loke volcanic cone is $1200 \mathrm{~m}$ in diameter with $150 \mathrm{~m}$ of vertical relief from a basal depth of more than $4000 \mathrm{~m}$. One CAMPER track line passed over the SE side of the structure, and two more surveyed the area immediately NE of the cone. The southeastern wall of the cone appears to have been breached by a lava flow and/or collapsed such that the volcanic edifice is horseshoe-shaped (Figure 1b). The bathymetric "apron" that extends outwards from the volcano is comprised of multiple, low-relief, lava flows with obvious contacts that extend radially from the base of the cone. At the edge of the apron, over $500 \mathrm{~m}$ from the slopes of Loke, we found black, glassy pillows. Within the apron we observed a $>50$-m-wide lava channel that displayed typical morphologies of lineated sheets at the channel center surrounded by chaotic, jumbled textures and bordered by lobates (Figure 6) [Soule et al., 2005; Garry et al., 2006]. Sheet flows had hackly, chaotic, lineated, and ropy surface textures. On the volcanic cone some glassy lava surfaces (Figure $4 d$ ) were overlain by microbial mats. 


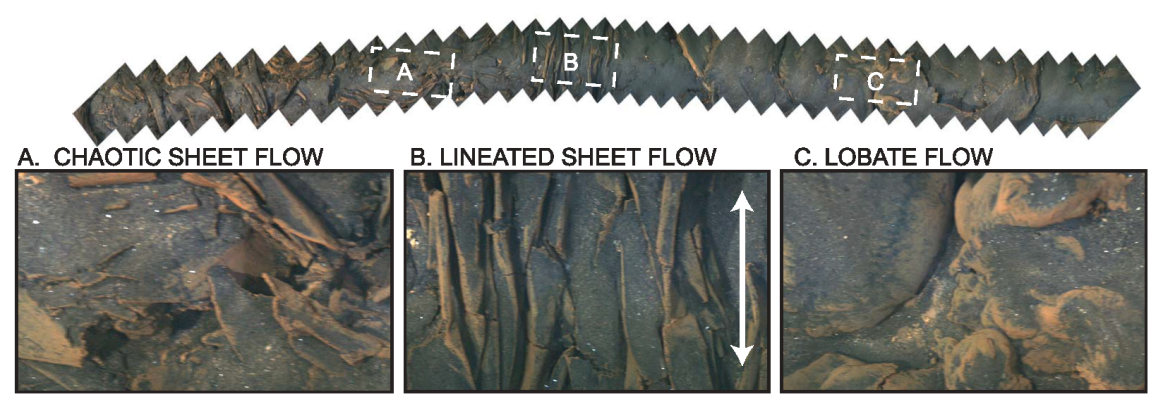

Figure 6. Sheet flow on Loke's apron Mosaic of a sheet flow on Loke's apron (see Figure 1b). Altered lavas covered in a moderate thickness of volcaniclastic deposits show a transition from chaotic sheet flow to lineated sheet flow, boarded by lobates. The white arrow in Figure $6 \mathrm{~b}$ denotes the approximate orientation of flow.

\subsubsection{Jessica's Hill and Duque's Hill Linear Ridges}

[23] Jessica's Hill is $5.5 \mathrm{~km}$ long, $1.8 \mathrm{~km}$ wide, and $0.4 \mathrm{~km}$ high with a peak at $3650 \mathrm{mbsl}$; Duque's Hill is $2.5 \mathrm{~km}$ long, $1.2 \mathrm{~km}$ wide, and $0.125 \mathrm{~km}$ high with a peak at $3820 \mathrm{mbsl}$. Both of these features are located on the northern volcanic lineament in the rift valley, and appear to be volcanic constructional features similar to axial volcanic ridges described on the slow-spreading Mid-Atlantic Ridge [Ballard and van Andel, 1977; Ramberg and van Andel, 1977; Smith and Cann, 1990, 1992; Searle et al., 2010]. The ridges consist primarily of orangestained, broken, pillow basalts and talus, and we did not observe any evidence of fresh eruptive products (i.e., glassy surfaces) on these features. Some pillows were ornamented, but all had dull or oxidized surfaces. The steep slopes of the ridges are characterized by elongate pillow lavas, and steep, 9-10 $\mathrm{m}$ high scarps consisting of fractured pillows were observed in six places. Both Jessica's Hill and Duque's Hill are covered with moderate to thick layers of volcaniclastic deposits, with the thickest coverage on Duque's Hill where the volcaniclasts completely bury the lavas and talus in many places (Figure 4g).

\subsection{Volcaniclastic Deposits}

\subsubsection{Deposit Thickness}

[24] Our qualitative evaluation of volcaniclastic layer thickness varied from a light dusting (Figure 4d) to up to $\sim 10 \mathrm{~cm}$ thick cover (Figure $4 \mathrm{~g}$ ) along the seafloor tracks (Figure 4c). Volcaniclastic deposits were thickest on the linear ridges and in the depression between the two volcanic lineaments, and thinnest on the glassy, unaltered lava flows identified on
Oden and Loke Volcanoes. Abrupt transitions in volcaniclastic deposit thickness were observed on the seafloor on the apron of Loke and on the flanks of the volcanoes, and often corresponded with other indicators of flow contacts between lavas of different relative ages (morphology, coloration). Volcaniclasts were present on lava surfaces of all ages and on nonvolcanic surfaces (e.g., talus slopes) suggesting that they were not derived from quench granulation of lava flows [e.g., Batiza et al., 1984]. In addition, volcaniclasts were piled on the tops of pillows high on ridgelines of Duque's Hill and Jessica's Hill, indicating deposit by fall rather than flow. Although difficult to quantify, there appeared to be a tendency for the clast layer to thicken downslope on the flanks of the linear ridges, suggesting some post-depositional downslope movement of material.

[25] In general, there is a correlation between the apparent (relative) age of the lava flows and the thickness of the volcaniclastic deposits, with the freshest-looking lavas being covered with a light dusting of material and the oldest-looking lava surfaces being covered with the thickest deposits. This suggests that the volcaniclasts have been deposited progressively over time, and that they are buried by younger lava flows. In most places it was not possible to discern any systematic spatial variations in clast grain size, but on the NE side of Oden Volcano the clast grain size appeared to increase toward the crater, and the largest clasts observed during our surveys were observed on the crater rim, suggesting that the crater may have been a source vent for volcaniclastic material. Within the crater, a light dusting of volcaniclastic material sat on, or was embedded into, the microbial mats, and could be observed on top of talus blocks protruding from the mats as well (Figure $5 \mathrm{c}$ ). 

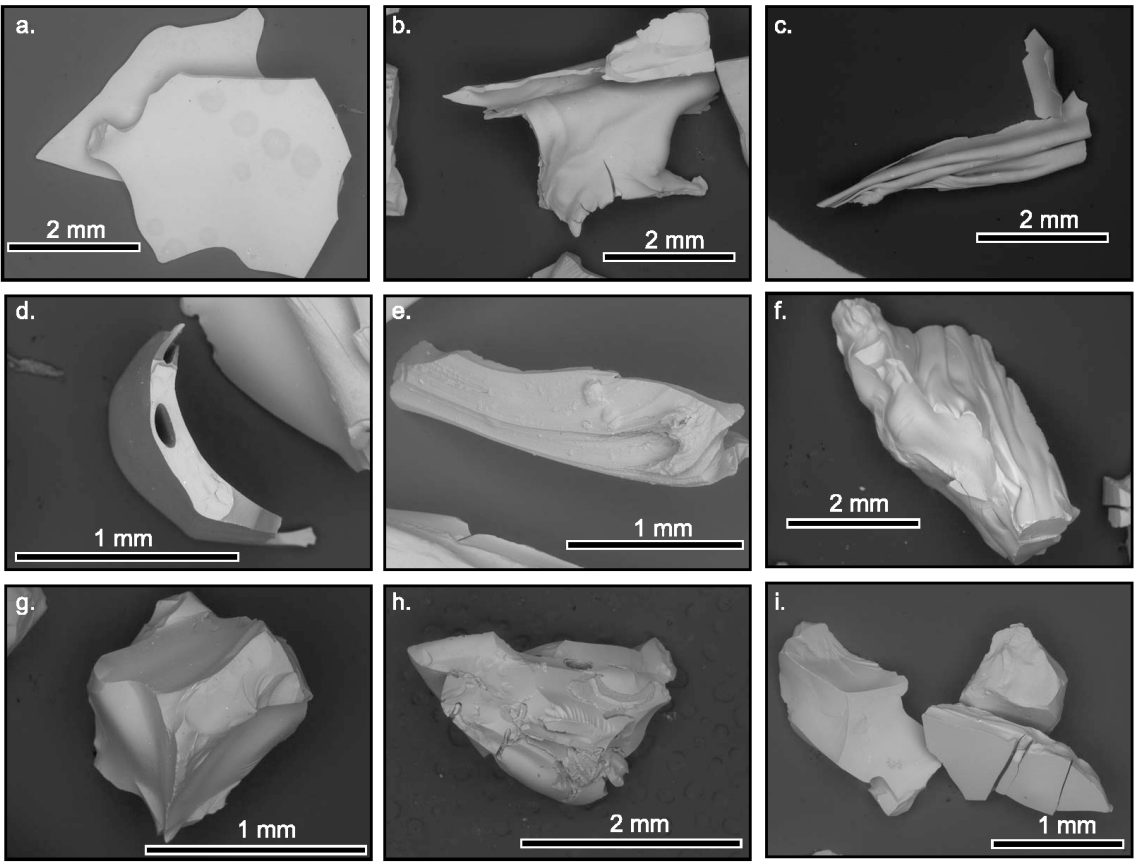

Figure 7. SEM images of volcaniclast morphologies. (a-c) Limu o Pele, or bubble-wall fragments and fluidal morphologies. $(\mathrm{d}-\mathrm{f})$ Platy clasts with crystalline inclusions and elongate vesicles. $(\mathrm{g}-\mathrm{i})$ Blocky dense fragments dominate the samples.

\subsubsection{Clast Morphologies}

[26] We analyzed volcaniclastic material from two suction samples acquired during our CAMPER surveys. Sample 12-1 was collected from the saddle between Jessica's Hill and Duque's Hill AVRs at a depth of $4000 \mathrm{~m}$, and Sample 13-1 was collected from thick deposits at the base of Duque's Hill at a depth of $4116 \mathrm{~m}$ (Figure 1b). Grain size analysis revealed clasts from fine volcanic ash $(<0.149 \mathrm{~mm})$ to greater than $4 \mathrm{~mm}$ in length. Mean grain size was consistent with volcaniclastic deposits from the slow-spreading Mid-Atlantic ridge [Eissen et al., 2003]. Details of grain-size sorting are described by Barreyre et al. [2011].

[27] We examined a representative sample of $\sim 1200$ volcaniclasts by stereo microscope and SEM for morphology and other characteristics including apparent age (juvenile or non-juvenile), material (glass, biogenic, or silt), and morphology (blocky, platy or tabular, or sheet-like). Both samples consist almost entirely of juvenile clasts of glassy basalt. Slightly vesicular blocky fragments dominate the deposits (Figures 7g-7i; see also Figures S8 and S9 in the auxiliary material). A moderate fraction of fragments $(<22$ wt. $\%$ and $<12$ wt. $\%$ for Samples $12-1$ and 13-1, respectively) are limu o pele bubble wall fragments [Mattox and Mangan, 1997; Maicher and White, 2001; Clague et al., 2009]. Some fragments preserve elongate vesicles or tubes, also representative of rapid quenching. Most vesicles imaged are not interconnected, indicating that the magma had limited permeability, which could facilitate the development of gas slugs [Namiki and Manga, 2008; Polacci et al., 2008; Schipper and White, 2010].

[28] Bubble-wall fragments are flat, curved, or complexly folded (Figures $7 \mathrm{a}-7 \mathrm{c}$ ). We also observed tubelike structures (Figure $7 \mathrm{~d}$ ), triple junctions, elongated vesicles, and surface textures preserved by rapid cooling (Figure 7a) [Clague et al., 2009]. Surfaces of limu o Pele fragments range from smooth to bumpy, the latter due to small inclusions of crystals and bubbles. No Pele's hair or rod shapes are evident in the samples. Dense, blocky volcaniclasts commonly display conchoidal fractures indicative of fracture at temperatures lower than the glass-transition temperature [Maicher et al., 2000]. There is a very small 


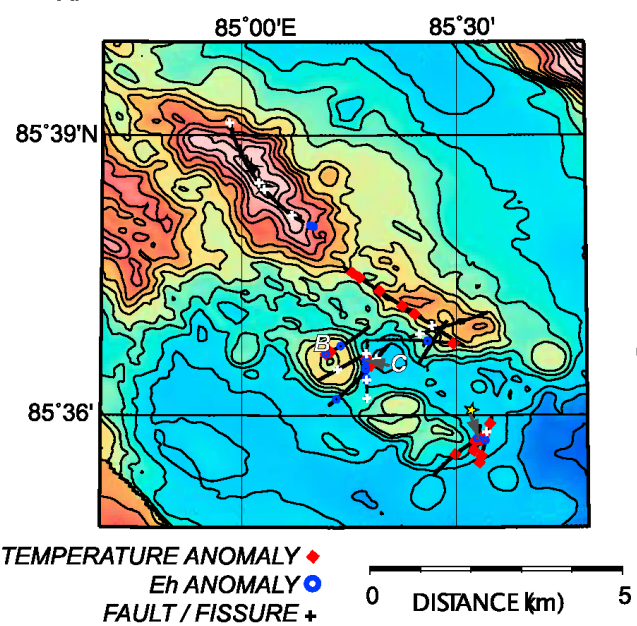

B.

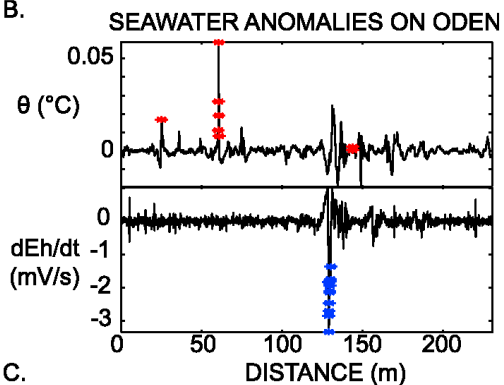

Figure 8. Near-bottom seawater anomalies. (a) A map shows locations of near-seafloor seawater temperature and Eh anomalies and faults and fissures. CTD data were not collected on Jessica's Hill. The yellow star denotes a visual observation of cloudy fluid $90 \mathrm{~m}$ above the seafloor of Loke's apron. (b) Concurrent measurements of potential temperature and $E h$ records during deployment DCS-15 on Oden show temperature and $E h$ anomalies (diamonds and dots, respectively) detected within tens of meters of one another on the edifice. (c) Cloudy fluid emanates from beneath an overhanging ledge on Oden Volcano where temperature and $E h$ anomalies are detected. Yellow microbial mats coat the rocks.

component of crystalline and altered basalt rock in the samples but it is not clear whether these are from the volcaniclastic deposits or originated from underlying intact lava flows. Free olivine containing melt inclusions [Shaw et al., 2010] and a small component of altered clasts with orange colorations, which may be palagonite, were also observed.

\subsection{Near-Bottom Water Column Anomalies}

[29] As described in section 3.2, the CAMPER vehicle was equipped with sensors to detect near-bottom water column anomalies in temperature and $E h$, which can be used to detect regions of hydrothermal discharge [Baker et al., 1994; Nakamura et al., 2000].

[30] Near-bottom (1-3 $\mathrm{m}$ above the seafloor) temperature anomalies ( $\delta \theta$ of $0.005-0.019^{\circ} \mathrm{C}$ ) were observed over Duque's Hill, Oden Volcano, and Loke Volcano (Figure 8; see also Table S1 in the auxiliary material). Twenty-three $E h$ anomalies were detected on the flank of Oden Volcano. No anomalies were detected on the seafloor between the volcanic lineaments.

[31] Many of the Eh anomalies measured on Oden Volcano were concurrent with observations of dense microbial mats (Figure 9). One or two near- bottom $E h$ anomalies were detected over Duque's Hill, Jessica's Hill, and the apron of Loke Volcano. Oden and the apron of Loke are the only places where temperature and $E h$ anomalies were colocated. Within the crater of Oden Volcano, the tips of orange-stained talus blocks protruded through near-continuous microbial mat (Figure 5c) and seawater measurements identified temperature and $E h$ anomalies within $20 \mathrm{~m}$ of one another (Figure $8 b$ ). On the flanks of the volcano, in one collapse pit, a pool of cloudy water was observed (the only place in our imagery where hydrothermal fluids could be observed discharging from the seafloor) simultaneously with a strong $E h$ anomaly (Figure 8c) and observations of microbial mats (Figure 9). Loke Volcano also hosted extensive microbial mats. On the apron of Loke Volcano, temperature and $E h$ anomalies were detected in the vicinity of a fissure and cloudy seawater was observed at $90 \mathrm{~m}$ above the seafloor during ascent of the CAMPER vehicle. On Duque's Hill no microbial mats were observed, but near-seafloor temperature and $E h$ anomalies were measured at several areas along the steep slopes. We observe $E h$ anomalies on Jessica's Hill and south of Oden in areas where microbial mats are not observed, suggesting that $E h$ anomalies have a hydrothermal source and are not generated by the microbial mats. 


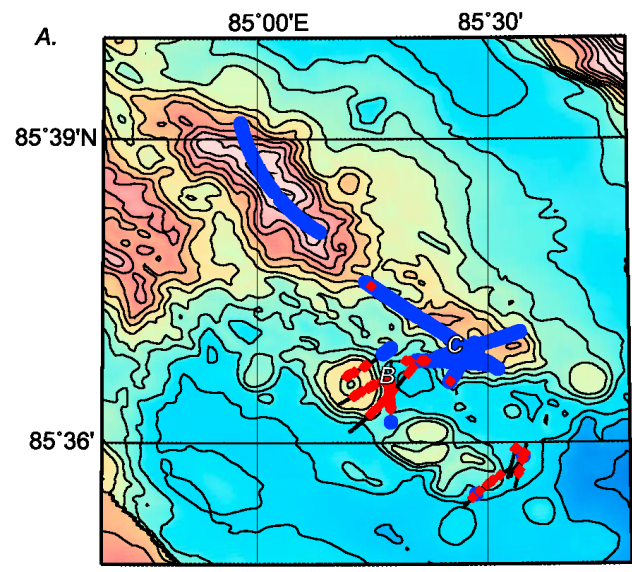

B.

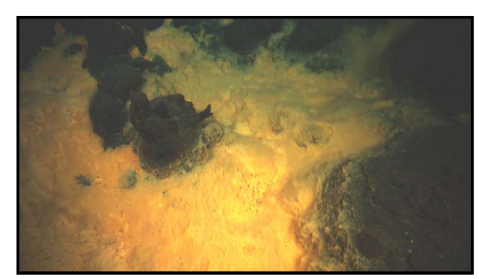

c.

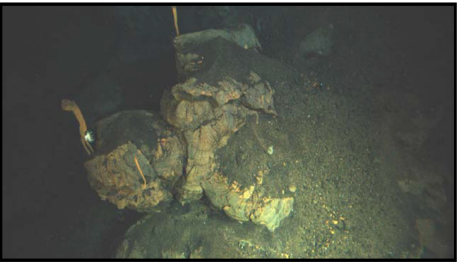

- MICROBIAL MATS

- SESSILE MACROBIOLOGY 0 DISTANCE (KM) 5

Figure 9. Locations of sessile biology. (a) A bathymetric map shows locations of microbial mats and sessile megafauna. Locations of (b) microbial mats correspond with areas of diffuse hydrothermal venting and observations of the youngest eruptive products on Oden and Loke Volcanoes. Sessile macrofauna such as (c) sponges and anemones are abundant on the relatively older seafloor of the axial volcanic ridges.

[32] Temperature and $E h$ anomalies (detected by CTD 'tow-yos') were ubiquitous higher in the water column over wide portions of the rift valley [Stranne et al., 2010], and modeling of these data indicated that there are up to six distinct sites of hydrothermal discharge on the seafloor within the axial valley. Inferred discharge sites from water column data agree with sites of our near-bottom anomalies, and near-seafloor measurements show that water anomalies are detected over 100's of meters along the volcanic cones and ridges.

\section{Discussion}

[33] We assign relative ages of flow units using the abundance of volcanic glass, the degree of alteration of lava surfaces, and the sediment cover [e.g., van Andel and Ballard, 1979]. These subjective criteria are not easily quantified and are affected by factors other than age alone. For example staining and palagonitization are useful indicators of age, but the presence of diffuse hydrothermal venting and microbial mats may also alter lava surface coloration. Although volcaniclastic deposition is likely not continuous in time or space, we use abrupt transitions in volcaniclastic thickness as a useful tool to support relative age inferences from other observations. The thickness of a submarine volcaniclastic deposit depends on the age of the lava flow on which it rests, proximity to the source vent, and to a lesser degree, post-depositional transport [e.g., Barreyre et al., 2011]. The relative abundance of sessile biology also provides an indication of seafloor age because colonization begins at the time of lava flow emplacement and appears to progress predictably with time [Shank et al., 1998].

\subsection{Recent Eruptions at $85^{\circ} \mathrm{E}$}

[34] Correlated lava surface morphology transitions and relative age indicators (e.g., staining, presence/ absence of fine ornamentation, volcaniclastic deposit thickness) suggest that the survey area has experienced numerous eruptions from volcanic vents scattered throughout the axial valley (Figure 10). Lava surfaces on the Oden volcanic cone vary from glassy, sometimes ornamented surfaces to orange-stained (Figures 5e and 5f). Although the extent of surface coloration may indicate eruption age, we note that the presence of hydrothermal anomalies in the area may expedite the lava surface alteration process, making pillows appear "prematurely" orange [Stroncik and Schmincke, 2002]. Alternatively, the microbial mats, which appear similar to mats composed of Feoxidizing bacteria on Loihi Volcano [e.g., Emerson and Moyer, 2002; Edwards et al., 2011] may be the primary cause of coloration [e.g., Staudigel and Clague, 2010]. As such, we are cautious when interpreting flow contacts and require variations in 


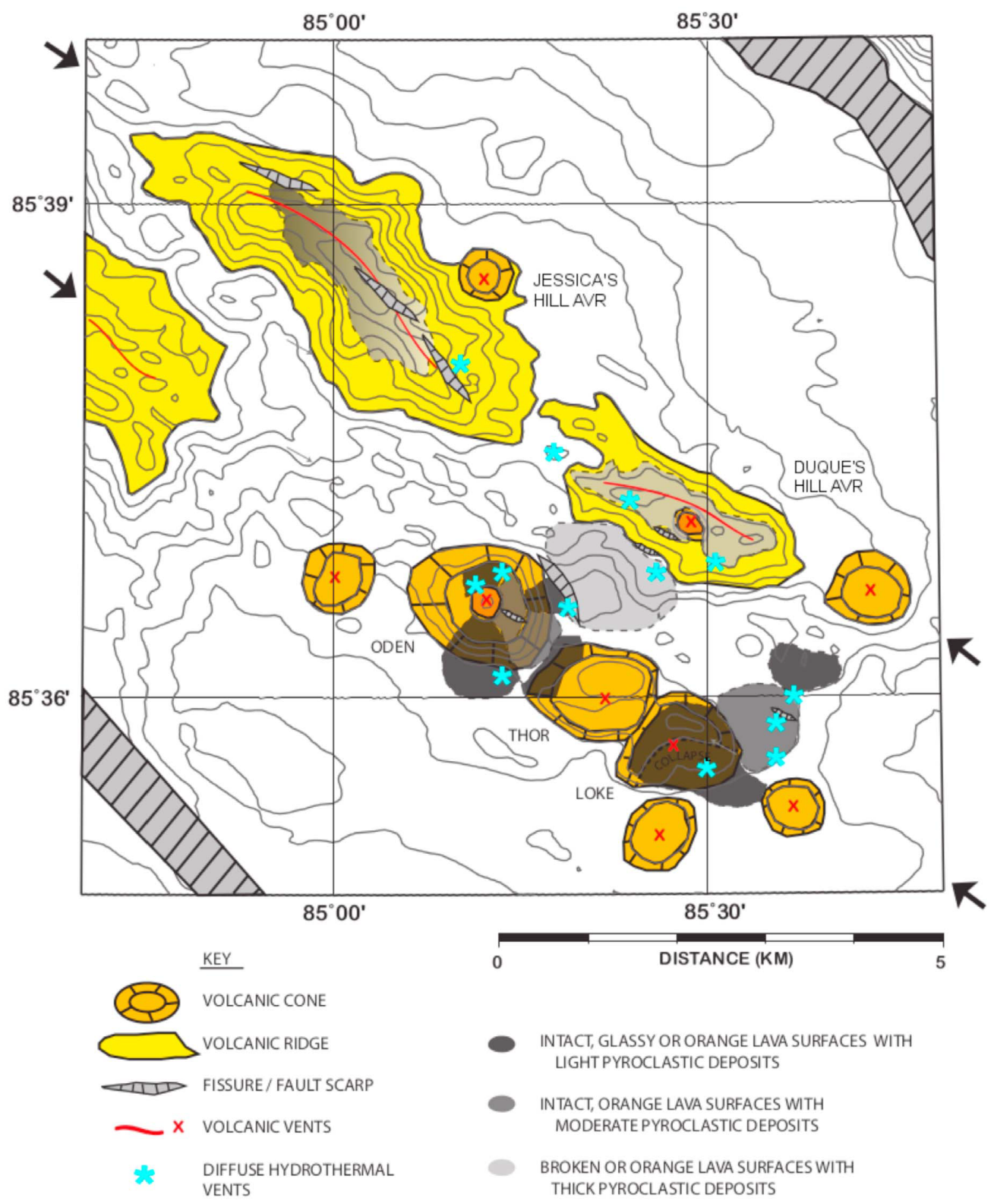

Figure 10. Interpretive map of volcanic features, small-volume effusive lava flows, pyroclastic deposits, and possible volcanic vents extrapolated from near-seafloor observations and bathymetry.

coloration to be accompanied by variations in morphology, degree of ornamentation, and volcaniclastic thickness.

[35] To better constrain relative ages of eruptions on Oden Volcano, we evaluate the distribution of volcaniclastic material on lava surfaces. Although volcaniclastic deposition is likely not continuous in time or space, differences in volcaniclastic thickness are a useful tool to support relative age inferences from other observations. For example, orangestained lava pillows on Oden's eastern rim are 
covered in a moderate thickness of volcaniclastic deposits, while the unstained, glassy, ornamented pillows on Oden's southern slopes have only a light dusting of volcaniclastic deposits. Oden's northern rim is also covered in ornamented pillows with a light dusting of volcaniclastic deposits, but lava surfaces on the northern rim are orange-stained, possibly due to rapid alteration by interaction with diffuse hydrothermal fluids detected in the area. Abrupt changes in volcaniclastic deposit thickness must represent contacts between flow units rather than spatial variations in distance from an explosive source, which would result in more gradual changes in deposit thickness. Thus Oden is constructed of products of at least two eruptions of distinct ages, one being very recent and possibly after, or coincident with, the emplacement of volcaniclastic deposits.

[36] A distinct contact was also observed between the relatively older, moderately volcaniclast-covered lava surfaces on Oden and lightly dusted, glassy, ornamented pillows oriented downslope on Thor Volcano, which look similarly fresh to glassy flows on Oden. On Loke Volcano fresh, glassy lava surfaces in conjunction with the light distribution of volcaniclasts suggests that the elongate pillow lavas that mantle the flanks of the volcanic cone erupted more recently and overlay the eruptive units on the apron. The eruptive apron is composed of high effusion rate sheet flows, is pervasively stained, and has accumulated more volcaniclastic material on its surface. Orientations of sheet flows suggest that lavas were transported radially from the central crater of the cone.

[37] We infer from the coincidence of glassy, elongate pillow lavas with ornamental buds, and a thin dusting of volcaniclastic deposits that Oden, Thor, and Loke Volcanoes are sites of the most recent eruptions. The extent of individual eruptive units are poorly constrained, but the identification of a few flow contacts suggest aerial extents on the order of $\sim 33 \%$ or less of the cone areas $\left(\sim 3 \mathrm{~km}^{2}\right)$. Given their thin volcaniclastic cover and fresh, glassy surfaces, these young flows on the volcanoes were emplaced slightly before or at the time of the most recent volcaniclastic eruption that is presumed to have occurred in 1999 [Müller and Jokat, 2000; Tolstoy et al., 2001]. Multiple, small-volume, eruptions on these volcanoes thus characterize the most recent effusive volcanic activity at $85^{\circ} \mathrm{E}$.

[38] Duque's Hill and Jessica's Hill are axial volcanic ridges (AVRs) constructed from multiple effusive eruptions that appear to have occurred earlier than the recent eruptions on the southern lineament. Both ridges are dominated by talus slopes, oxidized pillows, fractured seafloor, abundant sessile macrofauna, and a lack of microbial mats. The absence of sessile macrofauna on Oden and Loke Volcanoes and their presence on Jessica and Duque's Hills suggest that eruptions on the AVRs may be older than any of the volcanoes on the southern lineament. Despite their apparent older age, few faults and fissures are observed, although the presence of steep talus slopes provides indirect evidence of faulting. Jessica's Hill has some lobate flows at the ridgeline, indicating moderate flux eruptions. However, pillow eruptions dominate the lava morphology of both ridges. Both ridges are covered in a moderate to heavy thickness of volcaniclastic deposits. This is consistent with older eruption ages and hence longer periods of volcaniclast accumulation or proximity to a source.

[39] A relatively younger age for southern lineament volcanoes is supported by the abundance of near-seafloor temperature and $E h$ anomalies, and the absence of sessile macrofauna (Figure 9). Oden and Loke are the sources of numerous nearbottom seawater temperature and $E h$ anomalies detected by the CAMPER vehicle, indicating widespread diffuse hydrothermal discharge. Two plume horizons were also detected over the axial valley during the 2001 AMORE cruises, one at $\sim 2500 \mathrm{~m}$ and one at $\sim 3300 \mathrm{~m}\left(\Delta \theta>0.7^{\circ} \mathrm{C}\right)$, and were the most extensive and voluminous of any on the Gakkel Ridge [Edmonds et al., 2003; Baker et al., 2004]. Water column plume experiments during the AGAVE cruise also identified hydrothermal plumes confined within the axial valley walls at $3000-3800 \mathrm{~m}$ that were generated by vents on the valley floor. Given their low-temperature $\left(\mathrm{T}<10^{\circ} \mathrm{C}\right)$, these hydrothermal fluids did not disperse great distances despite the weakly stratified water column and were traced to six spatially distinct sites, including plumes above Oden and Loke [Stranne et al., 2010]. Near-seafloor temperature and $E h$ anomalies identified distinct locations of diffuse, low-temperature hydrothermal fluids over 100's of meters on Oden and the apron of Loke. The volcanoes also host extensive microbial mats that are supported by hydrothermal fluid flow [Helmke et al., 2007]. The microbial mats observed at the $85^{\circ} \mathrm{E}$ site are similar in appearance (i.e., orange, gelatinous texture) to those produced by Fe-oxidizing bacteria found at Loihi Seamount, Hawaii [e.g., Emerson and Moyer, 2002; Edwards et al., 2011]. The presence of diffuse hydrothermal discharge along both axis-parallel volcanic lineations suggests that regional tectonics make the seafloor permeable to hydrothermal 
circulation to a hot rock body underlying the valley floor and are key in controlling fluid discharge sites. However, the greater abundance of hydrothermal anomalies on the southern lineament suggests that the vigor of discharge is related to the relative age of volcanic activity.

\subsection{Volcanic Processes at $85^{\circ} \mathrm{E}$}

[40] Our evaluation of seafloor imagery from the 2007 AGAVE cruise, which is located within the area of high intensity backscatter identified by Edwards et al. [2001] (Figure 3), indicates that the region has experienced multiple, small-volume eruptions from discrete source vents over time. Our results agree with Edwards et al. [2001] interpretation of the area of high intensity backscatter as a region formed by multiple eruptions, which they based on observations of faults crosscutting the area. The sedimentation rate in the Gakkel Ridge is estimated to be $1-3 \mathrm{~cm} \mathrm{kyr}^{-1}$ [Backman et al., 2004] and penetration into pelagic sediment by the $12 \mathrm{kHz}$ SCICEX side scan sonar could easily exceed $1 \mathrm{~m}$ without dramatic signal attenuation [Mitchell, 1993], thus the region of high backscatter at $85^{\circ} \mathrm{E}$ could be produced by eruptions $>1$ million years in age. All glasses sampled on Oden and Loke [cf. Shaw et al., 2010] and volcaniclastic samples (Figure 1a) are age-constrained by U-series disequilibria (i.e., ${ }^{226} \mathrm{Ra}^{230} \mathrm{Th}=3.07$ to $3.65 \pm 3 \%$ ) to less than 8000 years, and one volcaniclastic sample (Sample 13-1) is age-constrained (i.e., ${ }^{210} \mathrm{~Pb} /{ }^{26} \mathrm{Ra}=0.89 \pm 9 \%$ ) to less than 100 years old [Elkins, 2009]. Thus, we conclude that the large region of high intensity backscatter from SCICEX 1999 represents a zone of seafloor (up to $1 \mathrm{Myr}$ in age) with thin pelagic sediment coverage and only a small area of fresh lavas on the southern lineament may be as recent as the 1999 seismic swarms. Our new observations of small-volume eruptions at the Gakkel Ridge challenge the hypothesis that eruption volume varies inversely with spreading rate across the global MOR system [Perfit and Chadwick, 1998; Sinton et al., 2002].

\subsection{Evidence of Deep Explosive Eruptions}

[41] Unconsolidated volcaniclastic depositsdominated by fine-grained, glassy clasts but also containing bubble-wall fragments-blanket the axial valley with variable thicknesses up to $10 \mathrm{~cm}$ over an area $\sim 5 \mathrm{~km} \times 10 \mathrm{~km}$. Although many formation mechanisms are postulated for submarine basaltic volcaniclasts (e.g., fuel-coolant interaction, quench granulation, hydromagmatic processes) the widespread distribution of deposits within the axial valley at depths greater than $3.6 \mathrm{~km}$ (e.g., at pressures greater than the critical point of seawater) point to formation by pyroclastic explosion [Büttner et al., 2002; Zimanowski and Büttner, 2003]. In particular, the abundance of the fresh volcaniclastic deposits on lava surfaces of varying ages argues against quench granulation from intact lava flows as a primary mechanism of formation. In addition, the presence of fresh volcaniclasts in the shallowest portions of the study area, where they are locally piled on top of pillows and on top of ridgelines, suggests that the volcaniclasts are deposited by falling through the water column rather than flow along the seafloor. This suggests that volcaniclasts are lofted into the water column at the eruptive vent. Similar clasts were recovered in box cores at the $60^{\circ} \mathrm{E}$ volcanic center on the Gakkel Ridge and may indicate similar explosive eruptions along the EVZ, though in that case clasts were interpreted as spallation from lava flow surfaces [Mühe et al., 1997].

[42] Volcaniclastic deposit thicknesses correlate with relative apparent ages of lava surfaces, with the thinnest deposits on near-zero-age lavas on Oden and Loke Volcanoes. On more oxidized, relatively older flows of Oden and Loke we observe thicker coverage. Abrupt changes in volcaniclastic deposit thickness at eruptive unit boundaries indicate thickness variations related to multiple episodes of explosive eruption rather than distance from a source, which would result in more gradual deposit variation. Deposits are thickest on the axial ridges, especially Duque's Hill, which we interpret to be the oldest surfaces in the study area. Overall, there is no clear gradient in volcaniclastic deposit thickness as would be expected with increasing proximity to an explosive source. If a single explosive source were to be invoked, it would have to be within or north of the two AVRs. However, the volcaniclastic deposits all appear to be much fresher than the lava flows on the AVRs, and the source of the youngest eruptions in the study are south of the AVRs on the southern lineament. From settling velocity experiments and modeling, Barreyre et al. [2011] found that a buoyant plume of hydrothermal fluid during an eruption (i.e., hydrothermal megaplume) could disperse clasts $\sim 400 \mathrm{~m}$ at most from a source vent on the Gakkel Ridge (assuming nominal current speeds of $\sim 1 \mathrm{~cm} / \mathrm{s}$ [Stranne et al., 2010]). Thus, multiple source vents distributed within the axial valley are required to disperse clasts along $\sim 10 \mathrm{~km}$ of seafloor and to create abrupt boundaries in deposit thickness. We further note that the cratered morphology and presence of unweathered talus on the summit and flanks of Oden Volcano are consistent with a Vulcanian 
explosion mechanism, where the catastrophic expansion of magmatic volatiles occurs in the shallow subsurface, thereby generating a central, talus-filled crater and ejecting talus blocks onto the summit rim and flanks of the cone.

\subsection{A Model of Effusive and Explosive Eruption at $85^{\circ} \mathrm{E}$}

[43] The depth of the axial valley of our study area at 3600-4200 mbsl is deeper than the maximum depth at which steam explosion can occur. The physical characteristics and widespread dispersal of the pyroclastic deposits lead us to suspect a highly energetic eruption driven by magmatic volatiles. Given the typical MORB geochemistry [Shaw et al., 2010] and low vesicularity of the samples, we presume that the $\mathrm{CO}_{2}$ driving the eruption must have accumulated at depth, largely decoupled from the erupting lava [Head and Wilson, 2003]. Thus magmatic volatiles, particularly $\mathrm{CO}_{2}$ because it has the smallest solubility of the major gases, represent the most likely driving force for explosivity [Bottinga and Javoy, 1990; Head and Wilson, 2003; White et al., 2003].

[44] $\mathrm{CO}_{2}$ exsolution can begin somewhere between $45-20 \mathrm{~km}$ below sea level in upward moving MORB depending on the initial concentration in the melt [Bottinga and Javoy, 1990]. Although Shaw et al. [2010] suggest that initial concentrations may not have been much higher than the maximum $\mathrm{CO}_{2}$ that they measured (1596 ppm), even small supersaturations at depths $>10 \mathrm{~km}$ would allow for some free gas to exsolve. We propose that over time a significant volume of exsolved volatiles may accumulate in crustal magma chambers. We assess the feasibility of such a model by examining the timescales of melting and magnitude of melt accumulation necessary to generate the required amounts of $\mathrm{CO}_{2}$ (see Appendix A). By modeling the amount of magma produced due to passive mantle upwelling [e.g., Forsyth, 1993] and calculating the supersaturation in $\mathrm{CO}_{2}$ at a given storage depth within the crust, we estimate that realistic timescales for gas accumulation would be on the order of 1500-2000 years. As the expected repose interval for eruptions at ultraslow spreading ridges is 10,000 to 100,000 years [e.g., Perfit and Chadwick, 1998], this timescale for melt accumulation suggests storage of $\mathrm{CO}_{2}$ in crustal reservoirs is a viable mechanism.

[45] Gas bubbles can form a foam layer in a reservoir with a gas volume fraction that can be stable over 90\% [Vergniolle and Jaupart, 1990]. The sequestered volatiles may then be released during an eruptive episode, leading to explosive discharge spreading pyroclastic material over seafloor areas proximal to the source vent [Head and Wilson, 2003; Sohn et al., 2008]. We propose that gasdepleted magma, rising more slowly in an eruption conduit, may also erupt during these explosive episodes. A slowly rising magma would erupt lowvesicularity, effusive flows in equilibrium with $\mathrm{CO}_{2}$ at seafloor depths, similar to those observed at the $85^{\circ} \mathrm{E}$ segment [e.g., Shaw et al., 2010]. This model is consistent with our observations of widespread pyroclastic deposits and avesicular, effusive lavas, and this type of eruption has been directly observed at W. Mata Volcano in the Lau Basin [Resing et al., 2011].

\section{Conclusions}

[46] Recent volcanic activity at the $85^{\circ} \mathrm{E}$ segment of the ultraslow spreading Gakkel Ridge consists of small volume effusive and explosive eruptions sourced from multiple volcanic features within the axial valley. These eruptions have produced AVRs and volcanic cones, with many of the latter exhibiting distinctive central craters. Similar volcanic cones and AVRs are observed in the axial valley at the very slow spreading Southwest Indian Ridge [Mendel and Sauter, 1997; Cannat et al., 1999; Sauter et al., 2001] as well as the slow spreading Mid-Atlantic Ridge [Smith and Cann, 1990]. All of the "fresh" lavas observed in our surveys were found on the southernmost volcanic lineament at the Oden, Thor, and Loke volcanic cones, which also coincides with the region where near-bottom $E h$ and thermal anomalies were observed in the water column, and where microbial mats were observed on the seafloor. These observations demonstrate that the 1999 seismic swarm may have been associated with a series of small volume eruptions featuring both explosive and effusive discharge.

[47] We model the widespread volcaniclastic deposits observed on the seafloor at the $85^{\circ} \mathrm{E}$ segment as having been generated by the explosive discharge of $\mathrm{CO}_{2}$ that accumulated in (possibly deep) crustal melt reservoirs over a period of time on the order of the eruption interval for an ultraslow-spreading ridge $(\sim 10,000 \mathrm{yr})$. We envision that $\mathrm{CO}_{2}$ 'bubbles' escaped from crustal melt reservoirs during eruptive events, rising through a more slowly ascending magma column before explosively discharging at, or in some cases just beneath, the seafloor. The energy released during explosive discharge, combined with the buoyant rise of hot fluid, lofts fragmented clasts of 
rapidly cooling magma into the water column, and they subsequently settle onto the seafloor as fall deposits in the region surrounding the source vent. The volcaniclasts themselves are avesicular with dissolved $\mathrm{CO}_{2}$ in equilibrium with seafloor pressures because magmas (unlike the gas bubbles) rise slowly in the eruption conduit, and therefore continually exsolve excess $\mathrm{CO}_{2}$ along their vertical path to the seafloor from the crustal melt reservoir. Excess gas exsolved from magmas during a slow rise to the seafloor may be incorporated into gas 'bubbles' escaping from the melt reservoir, and thereby enhance explosive activity.

\section{Appendix A: Accumulation of $\mathrm{CO}_{2}$ in a Crustal Magma Chamber}

[48] The physical characteristics of the volcaniclastic deposits lead us to suspect a highly energetic eruption driven by magmatic volatiles. Given the typical MORB geochemistry and low vesicularity of the samples, we presume that the $\mathrm{CO}_{2}$ driving the eruption must have accumulated at depth, largely decoupled from the erupting lava. We assess the feasibility of such a model by examining the timescales of melting and magnitude of melt accumulation necessary to generate the required amounts of $\mathrm{CO}_{2}$. Although the volume of gas required to drive an explosive eruption in this environment is not known, a conservative estimate is that the gas volume is 3 times that of the magma volume emplaced at the seafloor [e.g., Sohn et al., 2008; Head and Wilson, 2003].

[49] A minimum time to accumulate the $\mathrm{CO}_{2}$ is determined by assuming that $\mathrm{CO}_{2}$ behaves perfectly incompatibly and that all $\mathrm{CO}_{2}$ extracted from the mantle is available to contribute to an explosive eruption. The latter assumption is likely unreasonable, but places a lower bound on the timescale of melt generation. If all mantle that passes through the melting zone is stripped of its carbon by newly formed magmas, we can estimate the $\mathrm{CO}_{2}$ accumulation by assuming a mantle carbon concentration and the length of ridge over which melts are focused. The volume flux of mantle $\left(Q_{m}\right)$ through the melting region is related to spreading rate by,

$$
Q_{m}=\left(L_{x} L_{y}\right)\left(2 U_{o} / \pi\right)
$$

in the case of a uniform viscosity mantle [Reid and Jackson, 1981]. The melting column width $\left(L_{x}\right)$ is derived from the height of the melting column, which we set to $40 \mathrm{~km}$ (Figure S10 in the auxiliary material). The along-axis length of ridge from which melts accumulate $\left(L_{y}\right)$ is set to $30 \mathrm{~km}$, consistent with the spacing of volcanic centers in the Eastern Volcanic Zone. The full spreading rate $\left(U_{o}\right)$ is $9 \mathrm{~mm} \mathrm{yr}^{-1}$. With a mantle density of $3500 \mathrm{~kg} \mathrm{~m}^{-3}$, a mantle $\mathrm{CO}_{2}$ concentration of 134 ppm [Shaw et al., 2010], and assuming ideal gas behavior, the time necessary to extract sufficient $\mathrm{CO}_{2}$ from the mantle is 1130 years for a $10^{6} \mathrm{~m}^{3}$ eruption (time scales linearly with eruption volume in this calculation).

[50] A more realistic estimate of the timescale of melt accumulation can be determined by modeling the amount of magma produced due to passive mantle upwelling and calculating the supersaturation in $\mathrm{CO}_{2}$ at a given storage depth within the crust. Here we rely on the formulation from Forsyth [1993], where melt production per unit length of ridge per unit time $(\dot{M})$ is related to spreading rate by:

$$
\dot{M}=\frac{B Z_{o}^{2} U_{o}}{2}
$$

where $B$ is the mantle melt productivity (fraction of melt per $\mathrm{km}$ of uplift above the solidus) and $Z_{o}$ is the thickness of the melting column (depth of solidus measured from the base of the crust). The amount of melt produced over the region (Figure S10 in the auxiliary material) as a function of time is combined with the $\mathrm{CO}_{2}$ contributed from the mantle over the same time interval and then the magma is stored at a depth of $7.5 \mathrm{~km}$ depth in the crust, consistent with data from melt inclusions from this area [Shaw et al., 2010]. At that depth $\mathrm{CO}_{2}$ solubility is $\sim 1200 \mathrm{ppm}$ $(0.0012 \mathrm{wt} \%)$ given observed water concentrations of $0.25 \mathrm{wt} \%$ [Shaw et al., 2010]. The annual melt production we calculate of $1.87 \times 10^{9} \mathrm{~kg} \mathrm{yr}^{-1}$ and the annual $\mathrm{CO}_{2}$ contribution from the mantle of $6.18 \times 10^{6} \mathrm{~kg} \mathrm{yr}^{-1}$ results in $\mathrm{CO}_{2}$ concentrations in the melt of $\sim 3300 \mathrm{ppm}$. Thus, nearly two-thirds of the $\mathrm{CO}_{2}$ extracted from the mantle could be stored as a free gas in a reasonably placed crustal magma chamber. As such, more realistic timescales for gas accumulation would be on the order of 1500-2000 years. As the expected repose interval for eruptions at ultraslow-spreading ridges is 10,000 to 100,000 years [e.g., Perfit and Chadwick, 1998], this timescale for melt accumulation suggests storage of $\mathrm{CO}_{2}$ in crustal reservoirs is a viable mechanism.

\section{Acknowledgments}

[51] Many thanks to A. Shaw, J. Bailey, J. Kemp, W. Lange and the Advanced Imaging Laboratory at WHOI, WHOI Graphics, 
and the crew of icebreaker I/B Oden. We gratefully acknowledge the financial support of the National Aeronautics and Space Administration, the National Science Foundation (N.S.F.), the International Polar Year 2007-2008, and Woods Hole Oceanographic Institution; and the graduate support provided by N.S.F., the NDSEG Fellowship, and WHOI Deep Ocean Exploration Institute.

\section{References}

Backman, J., M. Jakobsson, R. Løvlie, L. Polyak, and L. A. Febo (2004), Is the central Arctic Ocean a sediment starved basin?, Quat. Sci. Rev., 23, 1435-1454, doi:10.1016/ j.quascirev.2003.12.005

Baker, E. T., R. A. Feely, M. J. Mottl, F. T. Sansone, C. G. Wheat, J. A. Resing, and J. E. Lupton (1994), Hydrothermal plumes along the East Pacific Rise, $8^{\circ} 40^{\prime}$ to $11^{\circ} 50^{\prime} \mathrm{N}$ : Plume distribution and relationship to the apparent magmatic budget, Earth Planet. Sci. Lett., 128, 1-17, doi:10.1016/0012821X(94)90022-1.

Baker, E. T., H. N. Edmonds, P. J. Michael, W. Bach, H. J. B. Dick, J. E. Snow, S. L. Walker, N. R. Banerjee, and C. H. Langmuir (2004), Hydrothermal venting in magma deserts: The ultraslow-spreading Gakkel and Southwest Indian Ridges, Geochem. Geophys. Geosyst., 5, Q08002, doi:10.1029/ 2004GC000712.

Ballard, R. D., and T. H. van Andel (1977), Morphology and tectonics of the inner rift valley at lat $36^{\circ} 50^{\prime} \mathrm{N}$ on the MidAtlantic Ridge, Geol. Soc. Am. Bull., 88, 507-530, doi:10.1130/0016-7606(1977)88<507:MATOTI >2.0.CO;2.

Ballard, R. D., W. B. Bryan, J. R. Heirtzler, G. Keller, J. G. Moore, and T. van Andel (1975), Manned submersible operations in the FAMOUS area, Mid-Atlantic Ridge, Science, 190, 103-108.

Ballard, R. D., R. T. Holcomb, and T. H. van Andel (1979), The Galapagos rift at $86^{\circ} \mathrm{W}: 3$. Sheet flows, collapse pits and lava lakes of the rift valley, J. Geophys. Res., 84, 5407-5422, doi:10.1029/JB084iB10p05407.

Barreyre, T., S. A. Soule, and R. A. Sohn (2011), Dispersal of volcaniclasts during deep-sea eruptions: Settling velocities and entrainment in buoyant seawater plumes, J. Volcanol. Geotherm. Res., 205, 84-93, doi:10.1016/j.jvolgeores.2011.05.006

Batiza, R., D. J. Fornari, D. A. Vanko, and P. Lonsdale (1984), Craters, calderas, and hyaloclastites on young Pacific seamounts, J. Geophys. Res., 89(B10), 8371-8390, doi:10.1029/ JB089iB10p08371

Behn, M. D., and G. Ito (2008), Magmatic and tectonic extension at mid-ocean ridges: 1 . Controls on fault characteristics, Geochem. Geophys. Geosyst., 9, Q08010, doi:10.1029/ 2008 GC001965.

Bonatti, E., and C. G. A. Harrison (1988), Eruption styles of basalt in oceanic spreading ridges and seamounts: Effect of magma temperature and viscosity, J. Geophys. Res., 93(B4), 2967-2980, doi:10.1029/JB093iB04p02967.

Bottinga, Y., and M. Javoy (1990), MORB degassing: Bubble growth and ascent, Chem. Geol., 81, 255-270, doi:10.1016/ 0009-2541(90)90050-H

Bown, J. W., and R. S. White (1994), Variation with spreading rate of oceanic crustal thickness and geochemistry, Earth Planet. Sci. Lett., 121, 435-449, doi:10.1016/0012-821X(94) 90082-5.

Bryden, H. L. (1973), New polynomials for thermal expansion, adiabatic temperature gradient and potential temperature of sea water, Deep Sea Res., 20, 401-408.
Büttner, R. P. Dellino, L. La Volpe, V. Lorenz, and B. Zimanowski (2002), Thermohydraulic explosions in phreatomagmatic eruptions as evidenced by the comparison between pyroclasts and products from Molten Fuel Coolant Interaction experiments, J. Geophys. Res., 107(B11), 2277, doi:10.1029/2001JB000511.

Cann, J. R., and D. K. Smith (2005), Evolution of volcanism and faulting in a segment of the Mid-Atlantic Ridge at $25^{\circ} \mathrm{N}$, Geochem. Geophys. Geosyst., 6, Q09008, doi:10.1029/ 2005GC000954

Cannat, M. (1996), How thick is the magmatic crust at slow spreading oceanic ridges?, J. Geophys. Res., 101(B2), 2847-2857, doi:10.1029/95JB03116.

Cannat, M., C. Rommevaux-Jestin, D. Sauter, C. Deplus, and $\mathrm{V}$. Mendel (1999), Formation of the axial relief at the very slow spreading Southwest Indian Ridge $\left(49^{\circ}\right.$ to $\left.69^{\circ} \mathrm{E}\right)$, $J$. Geophys. Res., 104(B10), 22,825-22,843, doi:10.1029/ 1999JB900195.

Chadwick, W. W., Jr., D. S. Scheirer, R. W. Embley, and H. P. Johnson (2001), High-resolution bathymetric surveys using scanning sonars: Lava flow morphology, hydrothermal vents, and geologic structure at recent eruption sites on the Juan de Fuca Ridge, J. Geophys. Res., I06(B8), 16,075-16,099, doi:10.1029/2001JB000297.

Chadwick, W. W., K. V. Cashman, R. W. Embley, H. Matsumoto, R. P. Dziak, C. E. J. de Ronde, T. K. Lau, N. D. Deardorff, and S. G. Merle (2008), Direct video and hydrophone observations of submarine eruptions at NW Rota-1 volcano, Mariana arc, J. Geophys. Res., 113, B08S10, doi:10.1029/ 2007 JB005215.

Clague, D. A., A. S. Davis, J. L. Bischoff, J. E. Dixon, and R. Geyer (2000), Bubble-wall fragments formed by submarine steam explosions on Loihi Seamount and Kilauea Volcano, Bull. Volcanol., 61, 437-449, doi:10.1007/ PL00008910.

Clague, D. A., R. Batiza, J. Head, and A. S. Davis (2003), Pyroclastic and hydroclastic deposits on Loihi Seamount, Hawaii, in Explosive Subaqueous Volcanism, Geophys. Monogr. Ser., vol. 140, edited by J. D. L. White, J. L. Smellie, and D. A. Clague, pp. 73-95, AGU, Washington, D. C., doi:10.1029/ $140 \mathrm{GM} 05$.

Clague, D. A., J. B. Paduan, and A. S. Davis (2009), Widespread strombolian eruptions of mid-ocean ridge basalt, J. Volcanol. Geotherm. Res., 180, 171-188, doi:10.1016/ j.jvolgeores.2008.08.007.

Coakley, B. J., and J. R. Cochran (1998), Gravity evidence of very thin crust at the Gakkel Ridge (Arctic Ocean), Earth Planet. Sci. Lett., 162, 81-95, doi:10.1016/S0012821X(98)00158-7.

Cochran, J. R. (2008), Seamount volcanism along the Gakkel Ridge, Arctic Ocean, Geophys. J. Int., 174, 1153-1173, doi:10.1111/j.1365-246X.2008.03860.x.

Deardorff, N. D., K. V. Cashman, and W. W. Chadwick (2011), Observations of eruptive plume dynamics and pyroclastic deposits from submarine explosive eruptions at NW Rota-1, Mariana arc, J. Volcanol. Geotherm. Res., 202, 47-59, doi:10.1016/j.jvolgeores.2011.01.003

DeMets, C., R. G. Gordon, D. F. Argus, and S. Stein (1994), Current plate motions, Geophys. Res. Lett., 21, 2191-2194, doi: $10.1029 / 94$ GL02118.

Dick, H. J. B., J. Lin, and H. Schouten (2003), An ultraslow spreading class of ocean ridge, Nature, 426, 405-412, doi: 10.1038 /nature 02128

Driesner, T, and S. Geiger (2007), Numerical simulation of multiphase fluid flow in hydrothermal systems, in Fluid-Fluid 
Interactions, Rev. in Mineral. and Geochem., vol. 65, edited by A. Liebscher and C. A. Heinrich, pp. 187-212, Mineral. Soc. of Am., Washington, D. C., doi:10.2138/rmg.2007.65.6.

Edmonds, H. N., P. J. Michael, E. T. Baker, D. P. Connelly, J. E. Snow, C. H. Langmuir, J. H. B. Dick, R. Muhe, C. R. German, and D. W. Graham (2003), Discovery of abundant hydrothermal venting on the ultraslow spreading Gakkel ridge in the Arctic Ocean, Nature, 421, 252-256, doi:10.1038/ nature 01351.

Edwards, K. J., et al. (2011), Ultra-diffuse hydrothermal venting supports Fe-oxidizing bacteria and massive umber deposition at $5000 \mathrm{~m}$ off Hawaii, ISME J., 5, 1748-1758, doi:10.1038/ismej.2011.48

Edwards, M. H., and B. J. Coakley (2003), SCICEX investigations of the Arctic Ocean System, Chem. Erde, 63, 281-328, doi:10.1078/0009-2819-00039.

Edwards, M. H., G. J. Kurras, M. Tolstoy, D. R. Bohnenstiehl, B. J. Coakley, and J. R. Cochran (2001), Evidence of recent volcanic activity on the ultraslow spreading Gakkel ridge, Nature, 409, 808-812, doi:10.1038/35057258.

Eissen, J. P., Y. Fouquet, D. Hardy, and H. Ondreas (2003), Recent MORB volcaniclastic explosive deposits from between 500 and $1750 \mathrm{~m}$. b.s.l. on the axis of the Mid-Atlantic Ridge, south of the Azores, in Explosive Subaqueous Volcanism, Geophys. Monogr. Ser., vol. 140, edited by J. D. L. White, J. L. Smellie, and D. A. Clague, pp. 143-166, AGU, Washington, D. C., doi:10.1029/140GM09.

Elkins, L. J. (2009), Basalt petrogenesis beneath slow- and ultraslow-spreading Arctic mid-ocean ridges, $\mathrm{PhD}$ thesis, MITWHOI Jt. Program in Oceanogr., Mass. Inst. of Technol., Cambridge.

Emerson, D., and C. L. Moyer (2002), Neutrophilic Fe-oxidizing bacteria are abundant at the Loihi Seamount hydrothermal vents and play a major role in Fe oxide deposition, Appl. Environ. Microbiol., 68(6), 3085-3093, doi:10.1128/AEM. 68.6.3085-3093.2002

Fink, J. H., and R. W. Griffiths (1992), A laboratory analog study of the surface morphology of lava flows extruded from point and line sources, J. Volcanol. Geotherm. Res., 54, 19-32, doi:10.1016/0377-0273(92)90112-Q.

Fofonoff, N. P., and R. C. Millard Jr. (1983), Algorithms for computation of fundamental properties of seawater, UNESCO Tech. Pap. Mar. Sci., 44, U.N. Educ., Sci. and Cult. Organ., Paris.

Fornari, D. et al. (2004), Submarine lava flow emplacement at the East Pacific Rise $9^{\circ} 50^{\prime} \mathrm{N}$ : Implications for uppermost ocean crust stratigraphy and hydrothermal fluid circulation, in The Thermal Structure of the Ocean Crust and the Dynamics of Hydrothermal Circulation, Geophys. Monogr. Ser., vol. 148, edited by C. R. German, J. Lin, and L. M. Parson, pp. 187-218, AGU, Washington, D. C.

Forsyth, D. W. (1993), Crustal thickness and the average depth and degree of melting in fractional melting models of passive flow beneath mid-ocean ridges, J. Geophys. Res., 98(B9), 16,073-16,079, doi:10.1029/93JB01722.

Fundis, A. T., S. A. Soule, D. J. Fornari, and M. R. Perfit (2010), Paving the seafloor: Volcanic emplacement processes during the 2005-2006 eruptions at the fast spreading East Pacific Rise, $9^{\circ} 50^{\prime} \mathrm{N}$, Geochem. Geophys. Geosyst., 11, Q08024, doi:10.1029/2010GC003058.

Garry, W. B., T. K. P. Gregg, S. A. Soule, and D. J. Fornari (2006), Formation of submarine lava channel textures: Insights from laboratory simulations, J. Geophys. Res., 111, B03104, doi:10.1029/2005JB003796.
Gregg, T. K. P., and J. H. Fink (1995), Quantification of submarine lava-flow morphology through analog experiments, Geology, 23(1), 73-76, doi:10.1130/0091-7613(1995) $023<0073$ :QOSLFM $>2.3 . \mathrm{CO} ; 2$.

Head, J. W. I., and L. Wilson (2003), Deep submarine volcaniclastic eruptions: Theory and predicted landforms and deposits, J. Volcanol. Geotherm. Res., 121, 155-193, doi:10.1016/ S0377-0273(02)00425-0.

Helmke, E., et al. (2007), Microbial communities at nonvolcanic and volcanic sites of the Gakkel ridge, Eos Trans. $A G U, 88(52)$, Fall Meet. Suppl., Abstract OS42A-01.

Helo, C. M.-A. Longpre, N. Shimizu, D. A. Clague, and J. Stix (2011), Explosive eruptions at mid-ocean ridges driven by $\mathrm{CO}_{2}$-rich magmas, Nat. Geosci., 4, 260-263, doi:10.1038/ ngeo 1104.

Jakobsson, M., R. Macnab, L. Mayer, R. Anderson, M. Edwards, J. Hatzky, H.-W. Schenke, and P. Johnson (2008), An improved bathymetric portrayal of the Arctic Ocean: Implications for ocean modeling and geological, geophysical and oceanographic analyses, Geophys. Res. Lett., 35, L07602, doi:10.1029/2008GL033520.

Jokat, W., and M. C. Schmidt-Aursch (2007), Geophysical characteristics of the ultraslow spreading Gakkel Ridge, Arctic Ocean, Geophys. J. Int., 168, 983-998, doi:10.1111/ j.1365-246X.2006.03278.x.

Jokat, W., O. Ritzmann, M. C. Schmidt-Aursch, S. Drachev, S. Gauger, and J. Snow (2003), Geophysical evidence for reduced melt production on the Arctic ultraslow Gakkel midocean ridge, Nature, 423, 962-965, doi:10.1038/nature01706.

Korger, E. I. M., and V. Schlindwein (2012), Performance of localization algorithms for teleseismic mid-ocean ridge earthquakes: The 1999 Gakkel Ridge earthquake swarm and its geological interpretation, Geophys. J. Int., 188, 613-625, doi:10.1111/j.1365-246X.2011.05282.x.

Le Douaran, S., and J. Francheteau (1981), Axial depth anomalies from 10 to $50^{\circ}$ north along the Mid-Atlantic Ridge: Correlation with other mantle properties, Earth Planet. Sci. Lett., 54, 29-47, doi:10.1016/0012-821X(81)90066-2.

Lonsdale, P. (1977a), Abyssal pahoehoe with lava coils at the Galapagos rift, Geology, 5, 147-152, doi:10.1130/00917613(1977)5<147:APWLCA > 2.0.CO;2.

Lonsdale, P. (1977b), Structural geomorphology of a fastspreading rise crest: The East Pacific Rise near $3^{\circ} 25^{\prime} \mathrm{S}$, Mar. Geophys. Res., 3, 251-293, doi:10.1007/BF00285656.

Macdonald, K. C. (1982), Mid-Ocean Ridges: Fine scale tectonic, volcanic and hydrothermal processes within the plate boundary zone, Annu. Rev. Earth Planet. Sci., 10, 155-190, doi:10.1146/annurev.ea.10.050182.001103.

Maicher, D., and J. D. L. White (2001), The formation of deepsea Limu o Pele, Bull. Volcanol., 63, 482-496, doi:10.1007/ s004450100165.

Maicher, D., J. D. L. White, and R. Batiza (2000), Sheet hyaloclastite: Density-current deposits of quench no bubbleburst fragments from thin, glassy sheet lava flows, Seamount Six, eastern Pacific Ocean, Mar. Geol., 171, 75-94, doi:10.1016/S0025-3227(00)00109-2.

Mattox, T. N., and M. T. Mangan (1997), Littoral hydrovolcanic explosions: A case study of lava-seawater interaction at Kilauea Volcano, J. Volcanol. Geotherm. Res., 75, 1-17, doi:10.1016/S0377-0273(96)00048-0.

Mendel, V., and D. Sauter (1997), Seamount volcanism at the super slow-spreading Southwest Indian Ridge between $57^{\circ} \mathrm{E}$ and $70^{\circ} \mathrm{E}$, Geology, 25(2), 99-102.

Michael, P. J., et al. (2003), Magmatism and amagmatic seafloor generation at the ultraslow spreading Gakkel ridge, 
Arctic Ocean, Nature, 423, 956-961, doi:10.1038/ nature 01704

Mitchell, N. C. (1993), A model for attenuation of backscatter due to sediment accumulations and its application to determine sediment thickness with GLORIA sidescan sonar, J. Geophys. Res., 98(B12), 22,477-22,493, doi:10.1029/ 93JB02217.

Mühe, R., H. Bohrmann, D. Garbe-Schönberg, and H. Kassens (1997), E-MORB glasses from the Gakkel Ridge (Arctic Ocean) at $87^{\circ} \mathrm{N}$ : Evidence for the Earth's most northerly volcanic activity, Earth Planet. Sci. Lett., 152, 1-9, doi:10.1016/ S0012-821X(97)00152-0.

Müller, C., and W. Jokat (2000), Seismic evidence for volcanic activity discovered in central Arctic, Eos Trans. $A G U, 81$, 265-269, doi:10.1029/00EO00186.

Nakamura, K., S. Veirs, C. P. Sarason, R. E. McDuff, F. Stahr, D. R. Yoerger, and A. M. Bradley (2000), Electrochemical signals in rising buoyant plumes and tidally oscillating plumes at the Main Endeavour vent field, Juan de Fuca Ridge, Eos Trans, $A G U, 81(48)$, Fall Meet. Suppl., Abstract OS52I-05.

Namiki, A., and M. Manga (2008), Transition between fragmentation and permeable outgassing of low viscocity magmas, J. Volcanol. Geotherm. Res., 169, 48-60, doi:10.1016/ j.jvolgeores.2007.07.020.

Neumann, G. A., and D. W. Forsyth (1993), Comparison of marine gravity from shipboard and high-density satellite altimetry along the Mid-Atlantic Ridge, $30.5^{\circ}-35.5^{\circ} \mathrm{S}$, Geophys. Res. Lett., 20(15), 1639-1642, doi:10.1029/93GL01487.

Perfit, M. R., and W. W. Chadwick Jr. (1998), Magmatism at mid-ocean ridges: Constraints from volcanological and geochemical investigations, in Faulting and Magmatism at Mid-Ocean Ridges, Geophys. Monogr. Ser., vol. 106, edited by W. R. Buck et al., pp. 59-115, AGU, Washington, D. C., doi:10.1029/GM106p0059.

Polacci, M., D. R. Baker, L. Bai, and L. Mancini (2008), Large vesicles record pathways of degassing at basaltic volcanoes, Bull. Volcanol., 70, 1023-1029, doi:10.1007/s00445-0070184-8.

Ramberg, I. B., and T. H. van Andel (1977), Morphology and tectonic evolution of the rift valley at lat $36^{\circ} 30^{\prime} \mathrm{N}$, MidAtlantic Ridge, Geol. Soc. Am. Bull., 88, 577-586, doi:10.1130/0016-7606(1977)88<577:MATEOT>2.0.CO;2.

Reid, I., and H. R. Jackson (1981), Oceanic spreading rate and crustal thickness, Mar. Geophys. Res., 5, 165-172.

Resing, J. A., et al. (2011), Active submarine eruption of boninite in the northeastern Lau Basin, Nat. Geosci., 4(11), 799-806, doi:10.1038/ngeo1275.

Rubin, K. H., and J. M. Sinton (2007), Inferences on midocean ridge thermal and magmatic structure from MORB compositions, Earth Planet. Sci. Lett., 260, 257-276, doi:10.1016/i.eps1.2007.05.035.

Ryan, W. B. F., et al. (2009), Global Multi-Resolution Topography (GMRT) synthesis data set, Geochem. Geophys. Geosyst., 10, Q03014, doi:10.1029/2008GC002332.

Sauter, D., P. Patriat, C. Rommevaux-Jestin, M. Cannat, and A. Briais (2001), The Southwest Indian Ridge between $49^{\circ} 15^{\prime} \mathrm{E}$ and $57^{\circ} \mathrm{E}$ : Focused accretion and magma redistribution, Earth Planet. Sci. Lett., 192, 303-317, doi:10.1016/ S0012-821X(01)00455-1.

Schipper, C. I., and J. D. L. White (2010), No depth limit to hydrovolcanic limu o Pele: Analysis of limu from Lo'ihi Seamount, Hawai'i, Bull. Volcanol., 72, 149-164, doi:10.1007/ s00445-009-0315-5.
Schlindwein, V., and C. Riedel (2010), Location and source mechanism of sound signals at Gakkel ridge, Arctic Ocean: Submarine Strombolian activity in the 1999-2001 volcanic episode, Geochem. Geophys. Geosyst., 11, Q01002, doi:10.1029/ $2009 \mathrm{GC} 002706$.

Schlindwein, V., C. Müller, and W. Jokat (2007), Microseismicity of the ultraslow-spreading Gakkel Ridge, Arctic Ocean: A pilot study, Geophys. J. Int., 169, 100-112, doi:10.1111/ j.1365-246X.2006.03308.x.

Searle, R. C., et al. (2010), Structure and development of an axial volcanic ridge: Mid-Atlantic Ridge, $45^{\circ} \mathrm{N}$, Earth Planet. Sci. Lett., 299, 228-241, doi:10.1016/j.eps1.2010.09.003.

Sella, G. F., T. H. Dixon, and A. Mao (2002), REVEL: A model for recent plate velocities from space geodesy, J. Geophys. Res., 107(B4), 2081, doi:10.1029/2000JB000033.

Sempéré, J.-C., G. M. Purdy, and H. Schouten (1990), Segmentation of the Mid-Atlantic Ridge between $24^{\circ} \mathrm{N}$ and $30^{\circ} 40^{\prime} \mathrm{N}$, Nature, 344, 427-431, doi:10.1038/344427a0.

Sempéré, J.-C., J. Lin, H. S. Brown, H. Schouten, and G. M. Purdy (1993), Segmentation and morphotectonic variations along a slow-spreading center: The Mid-Atlantic Ridge $\left(24^{\circ} 00^{\prime} \mathrm{N}-30^{\circ} 40^{\prime} \mathrm{N}\right)$, Mar. Geophys. Res., 15, 153-200, doi: $10.1007 / \mathrm{BF} 01204232$.

Shank, T. M., D. J. Fornari, K. L. Von Damm, M. D. Lilley, R. M. Haymon, and R. A. Lutz (1998), Temporal and spatial patterns of biological community development at nascent deep-sea hydrothermal vents $\left(9^{\circ} 50^{\prime} \mathrm{N}\right.$, East Pacific Rise), Deep Sea Res., Part II, 45, 465-515, doi:10.1016/S0967-0645(97) 00089-1.

Shaw, A. M., M. D. Behn, S. E. Humphris, R. A. Sohn, and P. M. Gregg (2010), Deep pooling of low degree melts and volatile fluxes at the $85^{\circ} \mathrm{E}$ segment of the Gakkel Ridge: Evidence from olivine-hosted melt inclusions and glasses, Earth Planet. Sci. Lett., 289, 311-322, doi:10.1016/j.eps1.2009.11.018.

Sinton, J. M., and R. S. Detrich (1992), Mid-ocean ridge magma chambers, J. Geophys. Res., 97(B1), 197-216, doi:10.1029/ 91JB02508.

Sinton, J., E. Bergmanis, K. Rubin, R. Batiza, T. K. P. Gregg, K. Grönvold, K. C. Macdonald, and S. M. White (2002), Volcanic eruptions on mid-ocean ridges: New evidence from the superfast spreading East Pacific Rise, $17^{\circ}-19^{\circ} \mathrm{S}, J$. Geophys. Res., 107(B6), 2115, doi:10.1029/2000JB000090.

Small, C. (1994), A global analysis of mid-ocean ridge axial topography, Geophys. J. Int., 116, 64-84, doi:10.1111/ j.1365-246X.1994.tb02128.x.

Smith, D. K., and J. R. Cann (1990), Hundreds of small volcanoes on the median valley floor of the Mid-Atlantic Ridge at 24-30 N, Nature, 348, 152-155, doi:10.1038/348152a0.

Smith, D. K., and J. R. Cann (1992), The role of seamount volcanism in crustal construction at the Mid-Atlantic Ridge $\left(24^{\circ}-30^{\circ} \mathrm{N}\right), J$. Geophys. Res., 97(B2), 1645-1658, doi:10.1029/91JB02507.

Smith, D. K., and J. R. Cann (1993), Building the crust at the Mid-Atlantic Ridge, Nature, 365, 707-715, doi:10.1038/ $365707 \mathrm{a} 0$.

Sohn, R. A, et al. (2008), Explosive volcanism on the ultraslow spreading Gakkel Ridge, Arctic Ocean, Nature, 453, 1236-1238, doi:10.1038/nature07075.

Soule, S. A., D. J. Fornari, M. R. Perfit, M. A. Tivey, W. I. Ridley, and H. Schouten (2005), Channelized lava flows at the East Pacific Rise crest $9^{\circ}-10^{\circ} \mathrm{N}$ : The importance of offaxis lava transport in developing the architecture of young oceanic crust, Geochem. Geophys. Geosyst., 6, Q08005, doi:10.1029/2005GC000912. 
Soule, S. A., D. J. Fornari, M. R. Perfit, and K. H. Rubin (2007), New insights into mid-ocean ridge volcanic processes from the 2005-2006 eruption of the East Pacific Rise, $9^{\circ} 46^{\prime} \mathrm{N}-9^{\circ} 56^{\prime} \mathrm{N}$, Geology, 35, 1079-1082, doi:10.1130/ G23924A.1.

Soule, S. A., J. Escartín, and D. J. Fornari (2009), A record of eruption and intrusion at a fast spreading ridge axis: Axial summit trough of the East Pacific Rise at 9-10 N, Geochem. Geophys. Geosyst., 10, Q10T07, doi:10.1029/2008GC002354.

Standish, J. J., H. J. Dick, P. J. Michael, W. G. Melson, and T. O'Hearn (2008), MORB generation beneath the ultraslow spreading Southwest Indian Ridge $\left(9-25^{\circ} \mathrm{E}\right)$ : Major element chemistry and the importance of process versus source, Geochem. Geophys. Geosyst., 9, Q05004, doi:10.1029/ 2008 GC001959.

Staudigel, H., and D. A. Clague (2010), The geological history of deep-sea volcanoes: Biosphere, hydrosphere, and lithosphere interactions, Oceanography, 23(1), 58-71, doi:10.5670/ oceanog. 2010.62

Stranne, C., R. A. Sohn, B. Liljebladh, and K. Nakamura (2010), Analysis and modeling of hydrothermal plume data acquired from the $85^{\circ} \mathrm{E}$ segment of the Gakkel Ridge, J. Geophys. Res., 115, C06028, doi:10.1029/2009JC005776.

Stroncik, N. A., and H.-U. Schmincke (2002), Palagonite: A review, Int. J. Earth Sci., 91, 680-697, doi:10.1007/ s00531-001-0238-7.

Thiede, J., D. L. Clark, and Y. Herman (1990), Late Mesozoic and Cenozoic paleoceanography of the northern polar oceans, in The Arctic Ocean Region, vol. L, edited by A. Grantz, L. Johnson, and J. F. Sweeny, pp. 427-458, Geol. Soc. of Am., Boulder, Colo.
Tolstoy, M., D. R. Bohnenstiehl, M. H. Edwards, and G. J. Kurras (2001), Seismic character of volcanic activity at the ultraslow-spreading Gakkel Ridge, Geology, 29(12), 1139-1142, doi:10.1130/0091-7613(2001)029<1139:SCOVAA > 2.0. $\mathrm{CO} ; 2$

van Andel, T. H., and R. D. Ballard (1979), The Galapagos Rift at $86^{\circ} \mathrm{W}: 2$. Volcanism, structure, and evolution of the rift valley, J. Geophys. Res., 84(B10), 5390-5606, doi:10.1029/ JB084iB10p05390.

Vergniolle, S., and C. Jaupart (1990), Dynamics of degassing at Kilauea Volcano, Hawaii, J. Geophys. Res., 95(B3), 2793-2809, doi:10.1029/JB095iB03p02793.

Vogt, P. R., P. T. Taylor, L. C. Kovacs, and G. L. Johnson (1979), Detailed aeromagnetic investigations of the Arctic Basin, J. Geophys. Res., 84, 1071-1089, doi:10.1029/ JB084iB03p01071.

White, J. D. L., J. L. Smellie, and D. A. Clague (Eds.) (2003), Explosive Subaqueous Volcanism, Geophys. Monogr. Ser., vol. 140, AGU, Washington, D. C., doi:10.1029/GM140.

Wright, I. C. (1994), Nature and tectonic setting of the southern Kermadec submarine arc volcanoes: An overview, Mar. Geol., 118, 217-236, doi:10.1016/0025-3227(94)90085-X.

Zimanowski, B., and R. Büttner (2003), Phreatomagmatic explosions in subaqueous volcanism, in Explosive Subaqueous Volcanism, edited by J. D. L. White, J. L. Smellie, and D. A. Clague, Geophys. Monogr. Ser., vol. 140, pp. 51-60, AGU, Washington, D. C., doi:10.1029/140GM03. 


\title{
Chapter 3: Reaction-driven microearthquakes at the Trans-Atlantic Geotraverse (TAG) active mound, Mid-Atlantic Ridge, $2^{\circ}{ }^{\circ} 08$ 'N
}

\begin{abstract}
A 9-month deployment of five ocean bottom seismometers (OBS) on the periphery of the Trans-Atlantic Geotraverse (TAG) active mound detected 32,078 very small, local microearthquakes (average $M_{L}=-0.95$ ) on at least four instruments from June 2003 to February 2004. Events occurred at a constant rate of up to 243 events per day for several months prior to an instrument failure and are characterized by durations of $<1$ second and single-phase $P$-wave arrivals (i.e., no $S$-arrivals). Accurate locations were determined for 6,207 of the earthquakes, with hypocenters clustered on the south and west flanks of the deposit at depths of $<125 \mathrm{~m}$ below the seafloor. The characteristics of the microearthquakes and their location within the horizon of mineral deposition observed in drill cores are consistent with a 'frost heave' fracturing mechanism driven by anhydrite deposition in the shallow secondary recharge circulation system of the TAG active mound.
\end{abstract}




\section{Introduction}

Seafloor massive sulfide deposits are the modern equivalents of ancient ophiolite-hosted ore deposits, such as those mined for copper and gold in Cyprus, Oman, and Newfoundland [Humphris et al., 1995; Hannington et al., 1998]. They were first recognized during explorations of deep-sea hydrothermal vent systems, where interactions between seawater and oceanic crust build massive sulfide deposits on the seafloor [Scott et al., 1974a, Scott et al., 1974b; Rona et al., 1975; Rona et al., 1986; Campbell et al., 1988; Karson and Rona, 1990; Herzig et al., 1998]. The TAG hydrothermal field on the seafloor of the Mid-Atlantic Ridge at $26^{\circ} \mathrm{N}$ (spreading rates 13 mm year ${ }^{-1}$ to the east and $11 \mathrm{~mm}$ year $^{-1}$ to the west) [McGregor and Rona, 1975; McGregor et al., 1977] consists of a zone of low-temperature deposits and alteration and three zones of high-temperature deposits and alteration spanning ages up to 100,000 years old [Rona et al., 1975, 1986, 1993; Thompson et al., 1985; Karson and Rona, 1990].

Genesis of seafloor massive sulfide deposit requires a heat source, and sometimes includes a secondary recharge system of seawater entrainment, a primary system of hydrothermal circulation, and chemical reaction with host rock. The TAG hydrothermal field sits in the extensional environment of a $\sim 5 \mathrm{~km}$ long shallow dipping $\left(20^{\circ}\right)$ domeshaped detachment fault [Tivey et al., 1993; Canales et al., 2007; deMartin et al., 2007] (Figure 1A). The detachment fault hanging wall is characterized by intersecting faults and fissures thought to structurally control the focusing of hydrothermal activity to the seafloor [Zonenshain et al., 1989; Rona,1990; Karson and Rona, 1990; Kleinrock and Humphris, 1996]. The seismogenic zone of the detachment fault extends to 7-8 $\mathrm{km}$ below the seafloor and may serve as a pathway for primary hydrothermal fluid circulation that fuels current high temperature venting [deMartin et al., 2007]. High temperature activity is currently focused at the TAG active mound, one of at least four large hydrothermal deposits in the field [White et al., 1998]. 
Investigations of the TAG active mound have revealed a zoned subsurface stratigraphy resulting from low and high-temperature reactions and an abundance of anhydrite within the deposit built by complex interactions between hydrothermal fluid, entrained seawater, and stockwork [Herzig et al., 1998]. Conceptually, the mound is built both by a focused primary fluid circulation system and by a secondary circulation system of conductively or convectively heated seawater, which is entrained into the deposit [c.f. Humphris and Tivey, 2000]. The mound has developed as a breccia pile through periods of venting activity and quiescence over at least 20,000 years [Rona, 1974; Lalou et al., 1990], and exhibits complex short-term episodic and periodic behaviors of venting [Sohn, 2007a,b]. In spite of the large body of knowledge on the TAG active mound, some key aspects of the hydrothermal system remain unclear. In particular, relatively little is know about the physical extent and geometry of hydraulic pathways and subsurface fluid flow. Defining the zone of secondary recharge is important for understanding where mineral deposition, especially that of anhydrite, occurs within the mound and the rate at which deposition occurs.

Hydrothermal activity intrinsically generates many microearthquakes [e.g., Kieffer, 1984; Ross et al., 1996; Bianco et al., 2004; Foulger et al., 2004, etc.]. Studies of hydrothermal systems have been done on land, but due to the difficulty of submarine observation, most oceanic microearthquake experiments have been on the scale of volcanic centers or ridge segments. Marine studies on fast spreading mid-ocean ridge systems have shown a direct correlation between fluid flow and local seismicity [Sohn et al., 1998; Johnson et al., 2000; Davis et al., 2004], however most studies represent feedbacks between tectonic faulting and venting. We know that changes in the flow within the subsurface at the TAG active mound are manifest at its surface by changes in its morphology and in the distribution of venting on very short time scales [Kleinrock and Humphris, 1996; Sohn, 2007a,b]. This is the first time that a seismic network small enough to detect and locate 
microearthquakes intrinsic to hydrothermal processes has been deployed at a seafloor massive sulfide deposit.

Analysis of small microearthquakes intrinsic to hydrothermal processes in the shallow crust requires a dense on-bottom seismic array with short inter-element spacings, in this case of $98 \mathrm{~m}$ to $203 \mathrm{~m}$. To investigate hydraulic phenomenon, we deployed a dense small aperture array of OBSs in a ring on the periphery of the TAG active mound. We detected 32,078 microearthquakes in a 9-month deployment, and located 6,207 events with standard errors of $20 \mathrm{~ms}$ or less. The microearthquake hypocenters collapse on the southern and western extents of the sulfide deposit in the top $125 \mathrm{~m}$ of crust. We use our results to investigate natural hydraulic fracturing processes and the maintenance of fluid pathways beneath the active hydrothermal system.

\section{The TAG Active Mound}

The TAG active mound is located within the rift valley, approximately $3 \mathrm{~km}$ west of the detachment fault termination and $2.4 \mathrm{~km}$ east of the ridge axis [Tivey et al., 2003]. Within the hanging wall block, orientations of $\sim 40 \%$ of fissures deviate significantly ( $>45^{\circ}$ ) from those predicted by the regional tectonic stress field, and small extensional fissures (several tens of meters in length and $0.7 \mathrm{~m}$ wide on average) crosscut 100,000-year-old crust (Figure 2B) [Kleinrock and Humphris, 1996; Bohnensteihl and Kleinrock, 2000]. First order estimates indicate that these fissures are restricted to $<500 \mathrm{~m}$ depth with a mean value of $70 \mathrm{~m}$ [Bohnenstiehl and Kleinrock, 2000]. These results indicate that the deposit is hosted on a highly permeable crustal block with a stress field that has been modified by the detachment faulting process.

The TAG active mound is a $\sim 200 \mathrm{~m}$ diameter, $\sim 50 \mathrm{~m}$ tall massive sulfide deposit that discharges hydrothermal fluids in excess of $360^{\circ} \mathrm{C}$ with a total heat flux of $\sim 1 \mathrm{GW}$ [Rona, 1984, Wichers, 2005]. On the basis of geochronological studies, high temperature venting 
at the TAG active mound is thought to have begun 20,000 - 50,000 years ago, with renewed pulses of activity every 5,000-6,000 years. These studies suggest that the most recent pulse of activity began $\sim 90$ years ago [Lalou et al., 1990, 1993, 1998; You and Bickle, 1998]. The active mound is believed to experience periods of quiescence during which anhydrite dissolves in response to cooling temperatures, leading to mass wasting and extensive reworking of the sulfides [Lalou et al., 1990; Humphris and Cann, 2000].

High-temperature fluid discharge is focused in an $~ 80 \mathrm{~m}$ wide upflow zone to the Black Smoker Complex (BSC), which constitutes a set of sulfide chimneys at the top of the mound [Honnorez et al., 1998]. Lower temperature fluids, presumably resulting from mixing of high-temperature fluids with cold seawater, discharge from a multitude of locations on the mound [Campbell et al., 1988; Edmond et al., 1995; Humphris et al., 1995; Tivey et al., 1995; Edmonds et al., 1998]. Exit-fluid temperature time-series data acquired from the active mound demonstrate that discharge and flow reversals in exit fluid temperature data, indicative of seawater entrainment into the mound surface, occur on complex episodic and periodic time scales [Sohn, 2007a,b].

\section{Experiment}

An ocean bottom seismometer (OBS) network was deployed at the TAG hydrothermal field from June, 2003 to February, 2004 as part of the Seismicity and Fluid Flow of the TAG Hydrothermal Mound (STAG) Experiment (Figure 2A). The OBS network consisted of three rings of instruments centered on the active hydrothermal mound with apertures of $200 \mathrm{~m}, 2 \mathrm{~km}$, and $8 \mathrm{~km}$. Here we report results from the smallest aperture sub-network, which was deployed around the periphery of the TAG active mound in an attempt to record very small microearthquakes associated with fluid flow in the deposit (Figure 2A). The sub-network consisted of five WHOI D2 OBSs, which are fourcomponent (3 geophone +1 hydrophone channel), short-period (4.5 Hz natural frequency) instruments. The seismometers recorded continuous data at $100 \mathrm{~Hz}$ for the 
nine-month duration of the deployment, except for STIR-12, which failed 77 days into the study for unknown reasons. The instruments were deployed by wire (rather than freefall) from the $R / V$ Knorr, and were positioned around the perimeter of the active mound using long baseline navigation techniques. This was the first deployment of a smallaperture (inter-element spacings of 98 - 203 m) OBS network on a deep-sea hydrothermal field.

\section{Data Analysis}

We present analyses for microearthquakes that were detected only on the $200 \mathrm{~m}$ aperture sub-network in order to focus on shallow seismic activity beneath the hydrothermal mound. The OBS network also detected a large number of local and regional tectonic events [deMartin et al., 2007], but these events are excluded from our analyses. In addition, we analyze events that are only detected by at least four instruments on the small aperture sub-network. We picked arrivals for 32,078 microearthquakes using a short-term average to long-term average algorithm, and then refined these picks using spectral methods [e.g. Song et al., 2010]. Linear clock drift corrections were applied to each station, and these corrections were further refined to account for non-linear clock drift by cross-correlating long-wavelength (> $500 \mathrm{~m})$ microseism signals [Webb, 1992; Webb and Crawford, 1999] propagating across the small-aperture sub-network. Finally, station corrections were applied to each record by subtracting the mean arrival time residual for all events.

Hypocenters were estimated using a stochastic grid search routine [Sohn et al., 1998] minimizing root mean square (rms) travel-time residuals between the phase picks and raytracing predictions over a $1.2 \mathrm{~km}$ cubic grid with $40 \mathrm{~m}$ node spacing. We used the average seismic ( $P$-wave) velocity vs depth profile for the TAG region from Canales et al., [2007] as a starting point for developing a velocity model for the raytracer. Because the seismic velocities in the shallowmost crust (i.e., extrusive lithologies in seismic layer 
2A) are not well-constrained in the Canales et al., [2007] model we systematically perturbed the shallow velocities and selected the model that minimized hypocentral errors for a subset of 1000 randomly selected events. Our final model has a $P$-wave velocity of $2.5 \mathrm{~km} \mathrm{~s}^{-1}$ at the seafloor that increases linearly with depth to a velocity of $\sim 4 \mathrm{~km} \mathrm{~s}^{-1}$ at 1 $\mathrm{km}$ below the seafloor, and it is draped over the local bathymetry, including the active mound [White et al., 1998; Roman and Singh, 2005]. The velocity model does not account for the different velocity structure of the sulfide deposit in the oceanic crust, which may add error to hypocenter estimates. Microearthquake moments and local magnitudes were calculated using standard techniques [e.g., Deichmann, 2006].

\section{Results}

We located 32,078 events detected during the 9-month OBS deployment. Seismicity rates during the deployment were essentially constant, although the rate decreased from 243 to 128 microearthquakes per day when STIR-12 failed 77 days into the experiment, and then decreased again to 97 events per day when whale calls [e.g., McDonald et al., 1995] in the study area masked signals from the smallest earthquakes (Figure 3). The spacetime microearthquake patterns do not exhibit mainshock-aftershock sequences, swarmlike behavior, nor evidence for migration. The spectrum of the microearthquake catalog (formed by treating the catalog as a point process, e.g., Brillinger, [1974]) does not exhibit strong periodicities and is not coherent with concurrently measured deep-sea tide gauge data (i.e., ocean tides) nor predicted solid earth tides (Figure 4).

Seismic moments for the microearthquakes, estimated from average event spectral levels between $5-50 \mathrm{~Hz}$ [Pearson, 1982], fall between $10^{13}-10^{16}$ dyne-cm, corresponding to local magnitudes of $-1.4 \leq M_{L} \leq 0.5$, with an average of -0.95 (Figure 5). The total moment release for these events over the 9-month deployment is $10^{18.6}$ dyne-cm, which is equivalent to a single event with a moment of $\sim 1.7$. For comparison, the microearthquakes associated with detachment faulting and tectonic extension observed at 
the TAG segment over the same time period with the large aperture OBS network had local magnitudes ranging from $1 \leq M_{L} \leq 4$ [deMartin et al., 2007].

\subsection{Microearthquake event characteristics}

Microearthquakes are characterized by impulsive, short-period $(15-30 \mathrm{~Hz}), P$-wave arrivals with durations of $<1 \mathrm{~s}$ (Figure 6). Event spectra contain peaks related to the frequency content of the source mechanism, as well as peaks at individual stations corresponding to coupling frequencies. $S$-arrivals are not generally observed in the data records, indicating that the events are generated by volume changes rather than shear failure on a fault surface. The small size of the earthquakes and poor signal-to-noise ratio makes it difficult to accurately determine the polarity of first arrivals. This, combined with the small number of stations available for analysis, precludes the estimation of reliable focal plane solutions for the microearthquakes. Furthermore, many of the events are demonstrably within the seismic near-field (i.e., less than one wavelength from the stations), which complicates waveform analysis and interpretation. We cross-correlated waveforms for 5000 randomly selected events with the next 100 events in time and 100 additional random events from the catalog to investigate waveform similarities that could be exploited for analytical purposes. We found that less than $1 \%$ of the catalog is correlated above a threshold of $r \geq 0.7$, such that it was not possible to use relative relocation nor stacking methods to refine our hypocentral and arrival polarity estimates. These results argue against repeating sources, although low signal-to-noise ratios and near-field propagation effects may also contribute to the lack of waveform similarity.

\subsection{Hypocenter locations}

We estimated hypocenters for 32,078 events, but roughly half of these estimates have rms errors $>200 \mathrm{~ms}$, and are therefore not suitable for detailed analyses and interpretation. 
This is to be expected considering the small number of stations (4-5 OBSs) available for analysis and the lack of $S$-arrivals. Most of the hypocenters, which have four degrees of freedom $\left(t_{0}, x, y, z\right)$, were estimated with four $P$-wave arrival times, leading to large uncertainties, particularly for events well outside the network aperture. We addressed this issue by focusing our analyses on the 6,207 events with hypocenter rms errors $<20 \mathrm{~ms}$ (Figure 7). Hypocenters for these events (Figure 8) have average 1- $\sigma$ confidence limits of $214 \mathrm{~m}, 202 \mathrm{~m}$, and $187 \mathrm{~m}$ in the north-south, east-west, and vertical directions, respectively. The most intense activity occurs to the south and west of the active mound within a narrow depth interval down to $200 \mathrm{mbsf}$. The velocity model used in microearthquake location is a simple one-dimensional velocity model draped over a three-dimensional grid. Microearthquake hypocenters often fall outside of the network. It is possible that many waveforms travel paths through the sulfide deposit, which is likely to have a very different velocity structure than the assumed model. If the different crustal structure beneath the sulfide deposit, which is a breccia, has lower seismic velocities, calculated locations of epicenters would locate closer to the hydrothermal mound than they are shown in Figure 8.

The low number of stations available for analysis combined with the low signal-to-noise ratio for many events produces considerable scatter in the hypocenters. Relative relocation methods based on waveform cross-correlation cannot be used to reduce scatter because of the lack of waveform similarity, but the collapsing method [Jones and Stewart, 1997] offers an appealing alternative. The collapsing method seeks the simplest structure that can be fit to the hypocenters by shifting event locations towards the geometric locus of the 3-dimensional error volumes. In other words, event hypocenters are moved within a confidence interval in a direction toward the center of mass of the events within the confidence interval (i.e. error ellipsoid). The only variable in the method is the significance level of the confidence ellipsoid. Collapsing method does not suggest that closely-collapsed events have similar source mechanisms or wave paths. 
Before applying the method we divided the events into two separate catalogues corresponding to before, and after, the failure of STIR-12 so that the results are not influenced by the change in network geometry that occurred at that time. After applying the collapsing method, the epicenters delineate a narrow ( $\sim 50$ m wide) zone of seismicity that wraps around the southwest corner of the active mound (Figure 9). Many of the events cluster in a narrow depth interval at $\sim 125 \mathrm{mbsf}$, with essentially no activity above this horizon, and more diffuse activity below. Some north-south striping is evident in hypocenters to the south of the mound, but this is most likely a result of the north-south orientation of the error ellipses in this area rather than geologic structure. Comparing the results of the collapsing method (Figure 9) to a density map of uncollapsed epicenters (Figure 10), we see that the method simply serves to highlight the densest seismic zone.

\section{Discussion}

Deploying a small-aperture ( 200 m) network of five OBSs around the perimeter of the TAG active mound allowed us to detect and locate large numbers $(\sim 32,000)$ of very small $\left(M_{L} \sim-1\right)$ microearthquakes within the zone of mineral deposition and/or alteration in the shallow crust (depth $<200 \mathrm{~m}$ ). These events are characterized by short-duration $(<1 \mathrm{~s})$, impulsive $P$-waves with little to no evidence for accompanying $S$-arrivals, indicating a non-double-couple (i.e., volume change) as opposed to a shear failure source mechanism. Flow-induced microearthquakes generated by volume change mechanisms have been observed in geothermal areas [e.g., Ross et al., 1996; Miller et al., 1998; Foulger et al., 2004] and hydraulic fracturing experiments [e.g., Aki et al., 1982; Cuenot et al., 2006;

Julian et al., 2007; Šílený et al., 2009], but this is the first time that a network small enough to detect and locate them has been deployed at a deep-sea hydrothermal field.

The dissimilarity between seismograms from different stations for the same event, despite the small network aperture, is striking. This is partly attributable to coupling effects - for example the spectral plots in Figure 6 show that STIR-13 has a coupling resonance at $\sim 15$ 
$\mathrm{Hz}$ - but most of the waveform dissimilarity is likely caused by scattering. Dissimilar microearthquake waveforms have also been observed on small-aperture networks deployed at the Old Faithful geyser in Yellowstone National Park [e.g., Kieffer, 1984; Kedar and Kanamori, 1998], suggesting that hydrothermal systems are associated with a high degree of structural heterogeneity in the shallow crust. This is consistent with the deposition of hydrothermal minerals in a complex fracture network, and mound building, in general, and it suggests that a sufficiently dense seismic network may have the potential to image these subsurface features.

Certain spectral peaks are observed at all stations for individual events, and these are likely associated with source processes. For the events shown in Figure 6, for example, there are common spectral peaks in the $20-40 \mathrm{~Hz}$ range, and if the source mechanisms were known it might be possible to use these peaks to constrain the physical properties and length scales of the source region. Unfortunately we do not have enough information to conduct this type of analysis with the data from this experiment, but here again we can see the potential value of deploying a dense seismic network on a deep-sea hydrothermal field.

Most of the events we located are within, or near the limit of, the seismic near-field of the network. Seismic wavelengths for the $P$-arrivals are on the order of $50-150 \mathrm{~m}$, which is comparable to the hypocentral distance for many events to some seismometers, such that the far-field assumption implicit in our analyses may not always be valid. Near-field propagation intertwines with both $\mathrm{P}$ and $\mathrm{S}$ arrivals, thus contaminating their observed polarizations [Aki and Richards, 2002; Lokmer and Bean, 2010], and thus could potentially play a role in the waveform dissimilarity that we observed. The near-field term decays as $1 / r^{2}$ to a distance of half the P-wavelength $(\sim 25-75 \mathrm{~m})$ from the source and $1 / r^{3}$ beyond that with distance $(r)$ from the source [Lokmer and Bean, 2010]. Thus nearfield disturbance cannot explain the lack of S-arrivals in our data, because most event hypocenters lie outside of the network and are more than a wavelength from at least some 
stations in the network. Filtering may be used to suppress near-field effects in homogeneous media, but in heterogeneous media it can only be accounted for with full 3dimensional modeling or full waveform inversion of the seismic wavefield [Lokmer and Bean, 2010; Li et al., 2011]. A detailed 3-dimensional seismic velocity model for the TAG active mound will therefore be required to accurately model the effects of near-field propagation on the seismograms.

\subsection{Potential source mechanisms}

Here we assess the compatibility of the observed microearthquakes with potential source mechanisms to identify plausible seismogenic scenarios. We do not have enough data to formally constrain the focal mechanisms, but the lack of $S$-arrivals can be used to rule out any source mechanism involving shear failure across a fault surface. Thus, although the hanging wall hosting the active mound is clearly tectonized and extended [e.g., Kleinrock and Humphris, 1996], tectonic faulting is inconsistent with the data. In addition, we do not observe any space-time correlation between the events observed at the active hydrothermal mound with the larger-scale seismicity associated with tectonic extension on the active detachment fault [deMartin et al., 2007].

Thermal contraction is a process than can generate very small microearthquakes, but it does not appear to provide a plausible mechanism for our data. Thermal contraction in a deep-sea hydrothermal system occurs in places where hot rock is being cooled by cold seawater, and this may generate small microearthquakes [e.g., Sohn et al., 2004]. However, the water-rock reaction zone where hot rock is cooled by hydrothermal fluids at TAG is somewhere at or below the detachment footwall interface (i.e., depths $>1.5 \mathrm{~km}$ below the seafloor), not in the upper $200 \mathrm{~m}$ of crust. The only plausible way to generate sustained rates of thermal contraction events in the shallow crust is by cooling a magmatic intrusion. For example, very small $\left(M_{L} \sim-1\right)$ microearthquakes with purely $P$ wave arrivals were observed by seismometers on the Kilauea Iki lava lake as it cooled in 
1976 [Chouet, 1979], and these events bear some resemblance to our data. However, the presence of a magma body in the shallow crust is precluded by the results of an active source seismic refraction study conducted during the STAG experiment [Canales et al., 2007]. We note that heat transfer in the shallow crust is a feature of hydrothermal circulation models for TAG, both through conductive heating from the 'pipe' that focuses hot fluids and convective mixing between hot hydrothermal fluids and cold pore fluids [Teagle et al., 1998; Lowell et al., 2003]. This heat transfer, which drives a secondary circulation system in the shallow crust, does not cool the crust and therefore does not trigger thermal contraction events.

Hydrothermal processes can generate non-double-couple events [e.g., Ross et al., 1996; Miller et al., 1998; Foulger et al., 2004], and the dense clustering of activity immediately beneath the mound is consistent with a hydrothermal mechanism. Three potential source mechanisms associated with hydrothermal processes have been identified: hydraulic fracturing, bubbles/vibrating fluids, and reaction-driven cracking. We consider each of these in turn. Hydraulic fracturing occurs when the fluid pressure somewhere in the circulation system exceeds the strength of the local host rock. Fluid pressures in the TAG circulation system are not well-constrained by observations, but the maximum fluid pressures in a high-temperature deep-sea hydrothermal system are constrained to be less than or equal to the buoyancy pressure, which is the difference between the pressure at the base of the recharge and discharge limbs of the convection cell [Cann and Strens, 1989]. The buoyancy pressure $(\Delta P)$ created by a convection cell with a depth of $z$, downgoing seawater at $2^{\circ} \mathrm{C}$ and density $\rho_{s w}$, and a discharge limb with hot fluid with density $\rho_{h t}$ at depth $z$ is:

$$
\Delta P=g z\left(\rho_{s w}-\rho_{h t}\right)
$$

where $g$ is gravitational acceleration. If we consider a secondary circulation system up to $200 \mathrm{~m}$ deep (i.e. the base of the microearthquake seismogenic zone) with $2^{\circ} \mathrm{C}$ seawater $\left(\rho_{s w}=1028 \mathrm{~kg} \mathrm{~m}^{3}\right)$ recharging the downgoing limb and $200^{\circ} \mathrm{C}$ to $400^{\circ} \mathrm{C}$ fluids with densities $\left(\rho_{h t}\right)$ of 874 and $579 \mathrm{~kg} \mathrm{~m}^{-3}$, respectively, at the base of the discharge limb 
[Bischoff and Rosenbauer, 1985; Seyfried, 1987], buoyancy pressure generated is 0.30 to $0.88 \mathrm{MPa}$. Assuming that fracturing occurs when buoyancy pressures reach lithostatic, which is $\sim 43 \mathrm{MPa}$ with overburden at $200 \mathrm{mbsf}$, it is not feasible to hydrofracture the host rock with such small buoyancy pressures. We can rule out hydrofracturing as a seismic source mechanism in the secondary recharge system. In the primary circulation system where fluids may penetrate along the detachment fault with temperatures of 700$900^{\circ} \mathrm{C}$ and fluid densities of 300-850 $\mathrm{kg} \mathrm{m}^{-3}$ [Palliser and McKibbin, 1998; Driesner, 2007], buoyancy pressures generated are 12-50 MPa. Again, buoyancy pressure is much less than lithostatic pressure (>200 MPa) at these depths, and hydrofracturing is not a likely source mechanism in the primary circulation system.

Collapsing bubbles and vibrating fluids are potential sources of hydrothermal microearthquakes and/or noise [Kieffer, 1984; Kedar et al., 1996; Kedar et al., 1998; Vandeulmeulebrouck et al., 2000], but they are typically observed in subaerial systems where there are large density changes associated with the phase transition from liquid to gas [Kieffer and Delany, 1979]. The TAG active mound is located at a depth of $3670 \mathrm{~m}$ where ambient pressures are super-critical (critical pressure in the ocean corresponds to depths of $\sim 3000 \mathrm{~m}$ ), and the volume change associated with the transition from a fluid to a super-critical vapor is $\sim 500$ times smaller at these conditions compared to a subaerial geothermal field [e.g., Driesner, 2007]. In addition, the frequency content of a bubble collapse event is controlled to first-order by the size (radius) of the bubble, the fluid density, and the ambient pressure [Rayleigh, 1917]. For idealized Rayleigh collapse at the ambient pressure of the TAG mound a bubble radius on the order of $10 \mathrm{~m}$ would be required to generate the $20-40 \mathrm{~Hz}$ signals we observed, which is clearly unrealistic. Finally, none of the TAG exit fluid samples acquired/analyzed to-date are saturated in any dissolved gases (e.g., $\mathrm{CO}_{2}, \mathrm{H}_{2}$ ) [Charlou et al., 1996]. Vibrating fluid mechanics also generate seismic harmonics that are absent from our microearthquake data. These pieces of evidence argue strongly against bubble collapse and vibrating fluid mechanisms for the microearthquakes we observed. 


\subsection{Reaction-driven cracking}

Reaction-driven cracking of the veins and breccias in response to mineral deposition appears to be the most plausible source mechanism for the microearthquakes we observed. The solid volume of the mineral deposit is continually increasing as hydrothermal minerals are deposited in flow veins, and this process (also known as 'frost heave' and 'salt weathering' in the literature) can generate large stresses that fracture the host matrix [Walder and Hallet, 1985; Scherer, 1999; 2004; Steiger, 2005a,b]. Cores recovered from the TAG active mound during ODP Leg 158 revealed breccias with an abundance of anhydrite veins, many of which contain textural evidence for fracturing. Anhydrite is a retrograde soluble mineral that precipitates from seawater when temperatures rise above $\sim 150^{\circ} \mathrm{C}$ through conductive heating or convective mixing with hydrothermal fluid, and dissolves at cooler temperatures [Edmond et al., 1995; Chiba et al., 1998; Teagle et al., 1998; Lowell and Yao, 2002]. The anhydrite veins fill complex, multistage fractures up to $45 \mathrm{~cm}$ in width [Humphris et al., 1996], with textures typical of open-space filling. Individual growth bands reflect sequential precipitation within cavities and repeated opening of fractures. Some anhydrite veins contain angular clasts of competent, low-porosity wallrock, indicative of fracturing (Figure 11). In samples with multiple veins, the host rock is commonly shattered and healed by late anhydrite [Humphris et al., 1996]. Textures of late anhydrite veining show that cementation and fracturing is a continual process during hydrothermally active periods. Anhydrite was recovered on broken clast surfaces and in veins and vugs throughout the stockworks zone, indicating that seawater penetrates to depths of at least 120 mbsf [Humphris, Herzig et al., 1996].

The ODP cores thus demonstrate that anhydrite precipitation and fracturing of the basalt matrix occur concurrently within the depth horizon of our microearthquakes. In the cores it was not possible to distinguish between a hydraulic vs. reaction-driven cracking 
mechanism, but as we showed earlier hydraulic pressures are not likely to reach fracturing thresholds in the secondary circulation system where anhydrite is deposited. Reaction-driven cracking is therefore the most probable fracturing mechanism accompanying anhydrite deposition, and here we assess the compatibility of this mechanism with our microearthquake data.

Data from drilled cores show that the anhydrite within the mound precipitated from mixtures of hydrothermal fluid and seawater heated to $>350^{\circ} \mathrm{C}$ [Mills et al., 1998; Tivey et al., 1998] in particular the analysis of fluid inclusions, show that anhydrite precipitates in the secondary circulation system when seawater is conductively heated to $108-383{ }^{\circ} \mathrm{C}$. Anhydrite precipitates from a fluid flowing through a permeable network (i.e. with deposition in fractures), which results in expansion of the solid volume filling the fracture. Volume expansion increases stresses on the fracture surface, and if the stresses are large enough a cracking event is triggered that opens the fracture and generates elastic waves (i.e., seismic energy) [e.g., Grossi et al., 1997]. Cracking maintains permeability and exposes fresh mineral surfaces in the fracture network, most likely anhydrite, creating a positive feedback with fluid flow and mineral precipitation.

To model the stresses generated by the precipitation of anhydrite at the TAG active mound we consider mode I tensile cracking of a penny-shaped fracture (Figure 11). We wish to estimate the fracture size required to generate the 'average' microearthquake observed in our study $\left(M_{L}=-0.95, M_{o}=3.7 \times 10^{14}\right.$ dyne-cm $)$. Consider a crack opening under tension in plane so that only the strain component $\Delta e_{33}$ is nonzero (Figure 12A). The moment density tensor in an isotropic medium is

$$
\boldsymbol{m}=\left(\begin{array}{ccc}
\lambda \Delta e & 0 & 0 \\
0 & \lambda \Delta e & 0 \\
0 & 0 & (\lambda+2 \mu) \Delta e
\end{array}\right)
$$

where $\lambda$ and $\mu$ are the Lame parameters of the medium (Table 1). The moment tensor is found by integrating over the source volume, $V$, 


$$
\boldsymbol{M}=-V\left(\begin{array}{ccc}
\lambda \Delta e & 0 & 0 \\
0 & \lambda \Delta e & 0 \\
0 & 0 & (\lambda+2 \mu) \Delta e
\end{array}\right)
$$

where the source volume is modeled as a cylindrical vein with radius $c$ and length $L$.

Note that the trace of the tensor is positive because the crack is opened. The scalar moment of the moment tensor is $M_{0}=\frac{1}{\sqrt{3}}(\boldsymbol{M}: \boldsymbol{M})^{1 / 2}$, which in this case is:

$$
M_{0}=\frac{\Delta e V}{\sqrt{3}} \sqrt{2 \lambda^{2}+(\lambda+2 \mu)^{2}} .
$$

Following the Scholz [2002] model for a penny-shaped crack, the relationship between stress drop and strain is

$$
\Delta \sigma=\frac{7 \pi}{16} \mu \Delta \mathrm{e}
$$

Thus, solving equation (5) for strain, we substitute the stress-strain relationship into the scalar moment equation to determine what source volumes are required to generate a microearthquake typical of those observed at the TAG active mound (i.e. $M_{0}=3.7 \times 10^{14}$ dyne-cm) for a given stress drop. The relationship between earthquake size, fracture size, and stress drop is given by Eqn (6). In other words, assuming $M_{0}=3.7 \times 10^{14}$ dyne-cm, we vary stress drop and solve for source volume,

$$
V \Delta \sigma=\sqrt{3} M_{0} \frac{7 \pi}{16} \mu\left[\sqrt{2 \lambda^{2}+(\lambda+2 \mu)^{2}}\right]^{-1} .
$$


Table 1. Lamé parameters and Young's moduli derived from seismic velocity and bulk density measurements of hand core samples of several rock types taken from TAG active mound subsurface [Ludwig et al., 1998].

\begin{tabular}{llllll}
\hline Rock Type & $\begin{array}{l}\text { Depth } \\
(\mathbf{m b s f})\end{array}$ & $\boldsymbol{\mu}(\mathbf{G P a})$ & $\boldsymbol{\lambda}(\mathbf{G P a})$ & $\mathbf{E}(\mathbf{G P a})$ & $\begin{array}{l}\text { Core section(s) } \\
\mathbf{1 5 8}-957\end{array}$ \\
\hline Altered basalt & $42.91-$ & 30.42 & 41.81 & 78.45 & $\mathrm{M}-9 \mathrm{R}-1,61-63 \mathrm{~cm} ;$ \\
& 46.67 & 30.42 & 44.23 & 78.86 & $10 \mathrm{R}-1,39-41 \mathrm{~cm} ;$ \\
& & 33.49 & 35.67 & 84.25 & $10 \mathrm{R}-1,47-49 \mathrm{~cm}$ \\
Silicified wallrock breccia & 72.90 & 41.77 & 22.78 & 98.27 & E- $8 \mathrm{R}-1,10-12 \mathrm{~cm}$ \\
$\begin{array}{l}\text { Chloritized basalt breccia } \\
\text { Nodular pyrite-silica }\end{array}$ & 106.80 & 44.85 & 22.89 & 104.86 & E- 15R-1, 30-32 cm \\
breccia & 40.14 & 45.74 & 17.39 & 104.08 & P- 9R-1, $4-6 \mathrm{~cm}$ \\
Pyrite-silica breccia & 56.31 & 74.95 & 44.16 & 177.68 & P- $12 \mathrm{R}-2,67-69 \mathrm{~cm}$ \\
\hline
\end{tabular}

Measured anhydrite veins in ODP cores have a median thickness of $L=4 \mathrm{~mm}$ [Humphris et al., 1996, Table 5]. If we assume that veins obey a linear fracture-length relationship, $L=C_{1}(2 c)$, where $L$ is the thickness or aperture, $c$ is the half-length, and $C_{1}=1.0 \times$ $10^{-3}$, a geologically representative aspect ratio [Vermilye and Scholz, 1995] then vein half-length is $2 \mathrm{~m}$. We model the source volume of the crack (Figure 12B) on dimensions of anhydrite veins (e.g. a penny-shaped crack $4 \mathrm{~mm}$ thick with a $4 \mathrm{~m}$ diameter has a volume of $V=\pi c^{2} L=5 \times 10^{-5} \mathrm{~m}^{3}$. There is no preferred orientation observed in vein dip and dips range from $0^{\circ}$ to $90^{\circ}$ [Humphris et al., 1996] so we consider confining and differential pressures at $100 \mathrm{~m}$ below the seafloor and $3630 \mathrm{~m}$ below the sea surface. 
Table 2. Source volume and stress drop required to generate a -0.95 magnitude microearthquake by opening a cylindrical crack in different rock types. We see that results of calculations are similar for the strength parameters of several different rock types.

\begin{tabular}{|c|c|c|c|c|c|c|}
\hline Rock Type & $\begin{array}{l}\text { Stress } \\
\text { Drop }\end{array}$ & $\begin{array}{l}\text { Source } \\
\text { Volume }\left(\mathbf{m}^{3}\right)\end{array}$ & $\begin{array}{l}\text { Crack } \\
\text { radius (m) }\end{array}$ & $\begin{array}{l}\text { Stress } \\
\text { Drop }\end{array}$ & $\begin{array}{l}\text { Source } \\
\text { Volume }\left(\mathbf{m}^{3}\right)\end{array}$ & $\begin{array}{l}\text { Crack } \\
\text { radius (m) }\end{array}$ \\
\hline \multirow{4}{*}{ Altered basalt } & \multirow{8}{*}{$\begin{array}{l}\text { Differential } \\
\text { Pressure of } \\
2.6 \mathrm{MPa}\end{array}$} & 8.54 & 11.08 & \multirow{8}{*}{$\begin{array}{l}\text { Confining } \\
\text { Pressure } \\
\text { of } 39 \\
\mathrm{MPa}\end{array}$} & 0.58 & 4.51 \\
\hline & & 8.27 & 10.96 & & 0.56 & 4.46 \\
\hline & & 9.74 & 11.57 & & 0.66 & 4.71 \\
\hline & & 9.43 & 11.45 & & 0.64 & 4.66 \\
\hline $\begin{array}{l}\text { Silicified } \\
\text { wallrock } \\
\text { breccia }\end{array}$ & & 12.50 & 12.58 & & 0.84 & 5.12 \\
\hline $\begin{array}{l}\text { Chloritized } \\
\text { basalt breccia }\end{array}$ & & 12.73 & 12.65 & & 0.86 & 5.15 \\
\hline $\begin{array}{l}\text { Nodular pyrite- } \\
\text { silica breccia }\end{array}$ & & 13.63 & 12.94 & & 0.92 & 5.27 \\
\hline $\begin{array}{l}\text { Pyrite-silica } \\
\text { breccia }\end{array}$ & & 12.22 & 12.23 & & 0.82 & 5.08 \\
\hline
\end{tabular}

Stress drop is perhaps the most difficult source parameter to constrain for any earthquake. Published values in the literature range from 0.1 and $100 \mathrm{MPa}$ [e.g. Abercrombie and Leary, 1993; Prejean and Ellsworth, 2001; Imanishi et al., 2004], but large uncertainties are typical. To cover the parameter space for the TAG active mound we consider three representative values: $2.6 \mathrm{MPa}=$ the differential pressure between hydrostatic and lithostatic pressure at a depth of $125 \mathrm{~m}, 39 \mathrm{MPa}=$ the confining pressure at a depth of $125 \mathrm{~m}$, and $100 \mathrm{MPa}=$ overpressures observed in salt weathering experiments [Steiger, 2005a]. Using these stress drop values we can calculate the size/volume of the associated fracture required to generate a $M_{L}=-0.95$ microearthquake (Table 1 ).

Table 3. Source volume by stress drop required to generate a -0.95 magnitude microearthquake in altered basalt.

\begin{tabular}{lll}
\hline Stress Drop & Source Volume $\left(\mathbf{m}^{3}\right)$ & Crack radius $(\mathbf{m})$ \\
\hline 100 MPa & 0.23 & 3.30 \\
Confining Pressure 39 MPa & 0.58 & 4.51 \\
Differential Pressure 2.6 MPa & 8.54 & 11.08 \\
\hline
\end{tabular}


The source volume required to generate an earthquake of a given size varies inversely with stress drop (Figure 13; Table 3). A stress drop equal to the differential pressure requires unreasonably large source volumes to generate the microearthquakes we observe, but stress drops greater than or equal to the confining pressure require reasonable source volumes of $\leq 0.58 \mathrm{~m}^{3}$. We therefore conclude that reaction-driven cracking is a plausible source mechanism for the microearthquakes we observed if the stress drop for individual events is greater than or equal to the confining pressure.

\subsection{Implications for Anhydrite Precipitation}

If our hypothesis that the microearthquakes we observed are generated by reaction-driven fracturing in response to anhydrite precipitation in the secondary circulation system is correct, then we can use our observations to constrain the location and volume of anhydrite deposited during our experiment. The microearthquakes cluster along two linear trends that intersect near the southwest corner of the active mound (Figure 9). These linear trends likely represent fissures. Although the region southwest of the mound is not adequately covered by the fine-scale microbathymetric map (Figure 2), fissures imaged in the area by ARGO II cameras and mapped by Bohnenstiehl and Kleinrock [2000] suggest that the trends may relate to specific surface features. Under our hypothesis these two linear trends demarcate a zone of focused anhydrite deposition within the depth interval from 100-200 mbsf. In cross-section we can see that the densest cluster of microearthquakes is focused in a narrow depth interval at $\sim 125 \mathrm{mbsf}$, and that there are essentially no events above this 'lid'. These patterns imply that recharge for secondary circulation is focused on two intersecting fissures just southwest of the mound, and that temperatures greater than $150^{\circ} \mathrm{C}$ required for anhydrite precipitation are reached at depths of less than $\sim 125 \mathrm{~m}$.

We can estimate the volume of anhydrite precipitated during our experiment by summing the volume change associated with each microearthquake that we observed. Because of 
the trade-off between stress drop and source volume in Eq. 6 we constrain the volume change by considering stress drops between confining pressure (39 $\mathrm{MPa}$ ) and crystallization pressures achieved during salt weathering experiments (100 MPa). Under these two scenarios, a $M_{L}=-0.95\left(M_{0}=3.7 \times 10^{14}\right.$ dyne-cm) microearthquake generates volume changes of $31 \mathrm{~cm}^{3}$ and $58 \mathrm{~cm}^{3}$, respectively. If we assume a seismicity rate of 243 microearthquakes per day (as observed at the beginning of the experiment before one of the instruments failed) then we obtain an annual volume change of between $27 \mathrm{~m}^{3}$ to 51 $\mathrm{m}^{3}$. The total volume of anhydrite within the active TAG deposit has been estimated to be $2 \times 10^{4} \mathrm{~m}^{3}$ [Tivey et al., 1998], such that it would take between 391 to 727 years to precipitate all the anhydrite in the deposit based on our estimated precipitation rates.

We can use these precipitation rate estimates to constrain the amount of heat and the volume of fluid required for anhydrite deposition. Assuming a precipitation rate $\left(r_{a n h}\right)$ of $\sim 0.0143 \mathrm{~mol}$ anhydrite per kilogram of fluid [Tivey et al., 1998] and a molar volume $\left(V_{\text {anh }}\right)$ of $4.6 \times 10^{-5} \mathrm{~m}^{3} \mathrm{~mol}^{-1}$ [Robie and Hemingway, 1995], first we determine the volume of entrained seawater required to match our rate estimates of anhydrite deposition $\left(R_{\text {anh }}\right)$ between $27 \mathrm{~m}^{3}$ to $51 \mathrm{~m}^{3}$ per year. After converting our estimated rate of anhydrite deposition to units of $\mathrm{m}^{3} \mathrm{~s}^{-1}$, the rate of seawater entrainment, $r_{s w}$, required to precipitate the anhydrite is

$$
r_{s w}=R_{a \mathrm{n} h}\left(r_{a n h} V_{a n h}\right)^{-1}
$$

which comes to an entrainment rate of 1.3 to $2.5 \mathrm{~kg} \mathrm{~s}^{-1}$ of seawater, on the order of $10^{7} \mathrm{~kg}$ of seawater per year. By comparison, the mass of hydrothermal fluid feeding the Black Smoker Complex is on the order of $10^{9} \mathrm{~kg}$ per year assuming that the Black Smoker operates at about $100 \mathrm{~kg} \mathrm{~s}-1$ [Hannington et al., 1998]. The estimated volume of seawater entrained is $\sim 1 \%$ of the flux of hydrothermal fluids through the Black Smoker Complex. 
We also use our precipitation rate estimates to constrain the heat flux required for anhydrite deposition. Following Tivey et al., [1998], if we entrain seawater at a rate $\left(r_{S W}\right)$ of 1.3 to $2.5 \mathrm{~kg} \mathrm{~s}^{-1}$, then the heat flux $(H)$ required to heat seawater from $2^{\circ}$ to $160^{\circ} \mathrm{C}$ or even $350^{\circ} \mathrm{C}$, the precipitation temperature of anhydrite, is

$$
H=r_{s w} c_{s w} \Delta T
$$

where $c_{s w}$ is the average heat capacity of seawater at 400 bars $\left(c_{s w}=4100 \mathrm{~J} \mathrm{~kg}^{-1} \mathrm{~K}^{-1}\right)$ [Bischoff and Rosenbauer, 1985]. The heat flux required to deposit our estimated volume of anhydrite is 0.8 to $3.6 \mathrm{MW}$, less than $1 \%$ of the $\sim 1 \mathrm{GW}$ total heat flux of the TAG active mound [Wichers, 2005].

\subsection{Implications of reaction-driven cracking in the TAG active mound subsurface}

The seismogenic zone of non-double couple microearthquakes is a narrow and shallow area arcing along the south and west sides of the TAG active mound. The spatial distribution of earthquakes suggests that seismicity illuminates an area of dilatant cracking driven by intense mineral precipitation which we infer to be the result of convective and conductive heating of entrained seawater (Figure 14B). Seismicity is offset from the center of the hydrothermal upflow zone under the Black Smoker Complex, presumably the highest thermal gradient and thermal stresses in the mound. The seismicity does not align with dominant through-going fault orientations (Figure 14), suggesting that regional stresses have little influence on focusing secondary recharge. The occurrence of microearthquakes randomly in time also suggests an interconnected hydraulic system, which is expected in the highly permeable shallow crust. Measurements of conductive heat flow on the west side of the sulfide rubble plateau that surrounds the Black Smoker Complex showed an area of very low heat flow 20-50 m in 1994 (Figure 14A) [Becker et al., 1996] supporting a region of local seawater entrainment west of the black smokers. Three-dimensional modeling of on-bottom gravity measurements show that the sulfide mound has a sharp change in thickness near the center of the mound from $50 \mathrm{~m}$ to the north to $10 \mathrm{~m}$ to the south [Evans, 1996]. The 
non-uniform distribution of inferred secondary recharge and seawater entrainment that we observe may be influenced by the asymmetry of the deposit. 


\section{References}

Abercrombie, R., and P. Leary (1993), Source parameters of small earthquakes recorded at $2.5 \mathrm{~km}$ depth, Cajon Pass, Southern California: Implications for earthquake scaling, Geophys. Res. Lett., 20(14), 1511-1514.

Aki, K., M. Fehler, R. L. Aamodt, J. N. Albright, R. M. Potter, C. M. Pearson, and J. W. Tester (1982), Interpretation of seismic data from hydraulic fracturing experiments at the Fenton Hill, New Mexico, hot dry rock geothermal site, $J$. Geophys. Res., 87(B2), 936-944, doi:10.1029/JB087iB02p00936.

Aki, K., and P. G. Richards (2002), Quantitative Seismology. University Science Books, Sausalito, California. 700pp.

Alt, J. C., and D. A. H. Teagle (1998), Probing the TAG hydrothermal mound an stockwork: Oxygen isotopic profiles from deep ocean drailling, in Proceedings of the Ocean Drilling Program, Scientific Results, vol. 158, edited by P. M. Herzig, S. E. Humphris, et al., College Station, Texas, Ocean Drilling Program, pp. 285295.

Bame, D., and M. Fehler (1986), Observations of long period earthquakes accompanying hydraulic fracturing, Geophys. Res. Lett., 13(1): 149-152.

Becker, K., R. Von Herzen, J. Kirklin, R. Evans, D. Kadko, M. Kinoshita, O. Matsubayashi, R. Mills, A. Schultz, and P. Rona (1996), Conductive heat flow at the TAG active hydrothermal mound: Results from 1993-1995 submersible surveys, Geophys. Res. Lett., 23, 3463-3466.

Bianco, F., E. Del Pezzo, G. Saccorotti, and G. Ventura (2004), The role of hydrothermal fluids in triggering the July-August 2000 seismic swarm at Campi Flegrei, Italy: evidence from seismological and mesostructural data, J. Volcanol. Geotherm. Res., 133, 229-246, doi: 10.1016/S0377-0273(03)00400-1.

Bird, P., Y. Y. Kagan, and D. D. Jackson (2003), Plate tectonics and earthquake potential of spreading ridges and oceanic transform faults, in Plate Boundary Zones, Geodynamics Series, vol. 30, edited by S. Stein, and J. T. Freymueller, pp. 203218, AGU, Washington, D. C.

Bischoff, J.L., and R. J. Rosenbauer (1985), An empirical equation of state for hydrothermal seawater (3.2 percent $\mathrm{NaCl})$, Am. J. Sci., 285, 725-763.

Bohnentiehl, D.R., and M. C. Kleinrock (2000), Fissuring near the TAG active hydrothermal mound, $26^{\circ} \mathrm{N}$ on the Mid-Atlantic Ridge, J. of Volcanol. and Geotherm. Res., 98, 33-48. 
Brillinger, D. R., Statistical inference for stationary point processes, Proceedings of the Summer Research Institute on Statistical Inference for Stochastic Processes, Bloomington, Indiana, July 31- August 9, 1974, Vol 1, p. 55-99.

Butterfield, D. A., G. J. Massoth, R. E. McDuff, J. E. Lupton, and M. D. Lilley (1990), Geochemistry of hydrothermal fluids from Axial Seamount hydrothermal emmisions study vent field, Juan de Fuca Ridge: Subseafloor boiling and subsequent fluid-rock interaction, J. Geophys. Res., 95(B8), 12895, doi : 10.1029/JB095IB08p12895.

Campbell, A. C., M. R. Palmer, G. P. Klinkhammer, T. S. Bowers, J. M. Edmond, J. R. Lawrence, J. F. Casey, G. Thompson, S. Humphris, P. Rona, and J. A. Karson (1988), Chemistry of hot springs on the Mid-Atlantic Ridge, Nature, 335(6), 514519.

Canales, J.P., R. A. Sohn, and B. J. deMartin (2007), Crustal structure of the TransAtlantic Geotraverse (TAG) segment (Mid-Atlantic Ridge, 26²100N): Implications for the nature of hydrothermal circulation and detachment faulting at slow spreading ridges, Geochem. Geophys. Geosys., 8(Q08004), doi:10.1029/2007GC001629.

Cann, J. R., and M. R. Strens (1989), Modeling periodic megaplume emission by black smoker systems, J. Geophys. Res., 94(B9), 12227-12237.

Charlou J. L., J. P. Donval, P. Jean-Baptiste, A. Dapoigny, and P. A. Rona (1996), Gases and helium isotopes in high temperature solutions sampled before and after ODP Leg 158 drilling at TAG hydrothermal field (26N, MAR). Geophys. Res. Lett., $23,3491-3494$

Chiba, H., N. Uchiyama, and D. A. H. Teagle (1998), Stable isotope study of an- hydrite and sulfide minerals at the TAG hydrothermal mound, Mid-Atlantic Ridge, $26^{\circ} \mathrm{N}$, in Proceedings of the Ocean Drilling Program, Scientific Results, vol. 158, edited by P. M. Herzig, S. E. Humphris, et al., pp. 85-90, College Station, Texas, Ocean Drilling Program.

Crone, T. J., and W. S. D. Wilcock (2005), Modeling the effects of tidal loading on midocean ridge hydrothermal systems, Geochem. Geophys. Geosys., 6(7), doi:10.1029/2004GC000905.

Cuenot, N., J. Charlety, L. Dorbath, and H. Haessler (2006), Faulting mechanisms and stress regime at the European HDR site of Soultz-sous- Forets, France, Geothermics, 35, 561-575, doi:10.1016/j.geothermics.2006.11.007. 
Davis, E., K. Becker, R. Dziak, J. Cassidy, K. Wang, and M. Lilley (2004), Hydrological response to a seafloor spreading episode on the Juan de Fuca ridge, Nature, 430, 335-338.

De Natale, G., C. Troise, and F. Pingue (2001), A mechanical fluid-dynamical model for ground movements at Campi Flegrei caldera, J. Geodyn., 32, 487-517, doi:10.1016/S0264-3707(01)00045-X.

Deichmann, N. (2006), Local magnitude, a moment revisited, Bull. Seism. Soc. Amer., 96(4A), 1267-1277, doi: 10.1785/0120050115.

deMartin, B. J., R. A. Sohn, J. P. Canales, and S. E. Humphris (2007), Kinematics and geometry of active detachment faulting beneath the Trans-Atlantic Geotraverse (TAG) hydrothermal field on the Mid-Atlantic Ridge, Geology, 35, 711-714.

Driesner, T. (2007), The system H2O-NaCl, Part II: Correlations for molar volume, enthalpy, and isobaric heat capacity from 0 to $1000 \_\mathrm{C}, 1$ to $5000 \mathrm{bar}$, and 0 to 1 $\mathrm{XNaCl}$, Geochim. Cosmochim. Acta, 71, 4902 - 4919, doi:10.1016/j.gca.2007.05.026.

Dziak, R. P., C. G. Fox, R. W. Embley, J. E. Lupton, G. C. Johnson, W. W. Chadwick, and R. A. Koski (1996), Detection of and response to a probable volcanogenic Twave event swarm on the western Blanco Transform Fault Zone, Geophys. Res. Lett., 23 (8), 873-876.

Edmond, J. M., A. C. Campbell, M. R. Palmer, G. P. Klinkhammer, C. R. German, H. N. Edmonds, H. Elderfield, G. Thompson, and P. A. Rona (1995), Time series studies of vent fluids from the TAG and MARK sites $(1986,1990)$ Mid-Atlantic Ridge: A new solution chemistry model and mechanism for $\mathrm{Cu} / \mathrm{Zn}$ zonation in massive sulfide orebodies, in Hydrothermal vents and processes, Geological Society of London Special Publication, vol. 87, edited by L. M. Parson, C. L. Walker, and D. R. Dixon, pp. 77-86.

Evans, R. L. (1996), A seafloor gravity profile across the TAG hydrothermal mound, Geophys. Res. Lett., 23, 3447-3450.

Ferrazzini, V., B. Chouet, M. Fehler, K. Aki (1990), Quantitative analysis of long-period events recorded during hydrofracture experiments at Fenton Hill, New Mexico, $J$. Geophys. Res., 95(B13), 21871, doi:10.1029/JB095iB13p21871.

Foreman, M. G. G. (1977), Manual for tidal heights analysis and prediction, Pacific Marine Science Report 77-10, Institute of Ocean Sciences, Patricia Bay, Sidney, B.C. 
Foulger, G. R., B. R. Julian, D. P. Hill, A. M. Pitt, P. E. Malin, and E. Shalev (2004), Non-double-couple microearthquakes at Long Valley Caldera, California, provide evidence for hydraulic fracturing, J. Volcanol. Geotherm. Res., 132, 45-71, doi: 10.1016/S0377-0273(03)00420-7.

Germanovich, L. N., and R.P. Lowell (1992), Percolation theory, thermoelasticity, and discrete hydrothermal venting in the Earth's crust, Science, 255, 1564-1567.

Golden, C. E., S. C. Webb, and R. A. Sohn (2003), Hydrothermal microearthquake swarms beneath active vents at Middle Valley, northern Juan de Fuca Ridge, $J$. Geophys. Res., 108(B1), 2027, doi:10.1029/2001JB000226.

Goldfarb, M. S., and J. R. Delaney (1988), Response of two-phase fluids to fracture configurations within submarine hydrothermal systems, J. Geophys. Res., 93(B5), 4585-4594.

Grossi, C. M., R. M. Esbert, L. M. Suárez del Río, M. Montoto, and M. Laurenzi-Tabasso (1997), Acoustic emission monitoring to study sodium sulphate crystallization in monumental porous carbonate stones, Studies in Conservation, 42(2), 115-125.

Herzig, P. M., S. Petersen, M. D. and Hannington (1998), Geochemistry and sulfur isotopic composition of the TAG hydrothermal mound, Mid-Atlantic Ridge, $26^{\circ} \mathrm{N}$, in Proceedings of the Ocean Drilling Program, Scientific Results, vol. 158, edited by P. M. Herzig, S. E. Humphris, et al., pp. 47-40, College Station, Texas, Ocean Drilling Program.

Honnorez, J. J., J. C. Alt, and S. E. Humphris (1998), Vivisection and autopsy of active and fossil hydrothermal alterations of basalt beneath and within the TAG hydrothermal mound, in Proceedings of the Ocean Drilling Program, Scientific Results, vol. 158, edited by P. M. Herzig, S. E. Humphris, et al., pp. 231-254, College Station, Texas, Ocean Drilling Program.

Humphris, S. E., P. M. Herzig, D. J. Miller, et al. (1995), The internal structure of an active sea-floor massive sulphide deposit, Nature, 377, 713-716.

Humphris, S. E., and M. C. Kleinrock (1996), Detailed morphology of the TAG active hydrothermal mound: Insights into its formation and growth, Geophys. Res. Lett., $23,3443-3446$.

Humphris, S., P. Herzig, J. Miller, J. Alt, K. Becker, D. Brown, et al. (1996), TAG-1 Area, in Proceedings of the Ocean Drilling Project, Initial Reports, vol. 158, edited by S. E. Humphris, P. Herzig, D. Miller, et al., pp. 65-140, College Station, TX: Ocean Drilling Program. 
Humphris, S.E., and J. R. Cann (2000), Constraints on the energy and chemical balances of the modern TAG and ancient Cyprus seafloor sulfide deposits, J. Geophys. Res., 105, 28477-28488.

Humphris, S. E., and M. K. Tivey (2000), A sysnthesis of geological and geochemical investigations of the TAG hydrothermal field: Insights into fluid-flow and mixing processes in a hydrothermal system, Geological Society of America, Special Ppaer 349, 213-235.

Humphris, S. E., and W. Bach (2005), On the Sr isotope and REE compositions of anhydrites form the TAG seafloor hydrothermal system, Geochimica et Cosmochimica Acta, 69(6), 1511-1525, doi:10.1016/j.gca.2004.10.004.

Hutnak, M., S. Hurwitz, S. E. Ingebritsen, and P. A. Hsieh (2009), Numerical models of caldera deformation: Effects of multiphase and multicomponent hydrothermal fluid flow, J. Geophys. Res., 114(B04411), doi: 10.1029/2008JB006151.

Imanishi, K., W. L. Ellsworth, S. G. Prejean (2004), Earthquake source parameters determined by the SAFOD Pilot Hole seismic array, Geophys. Res. Lett., 31(L12S09), doi:10.1029/2004GL019420.

James, R. H., and H. Elderfield (1996), The chemistry of ore-forming fluids and mineral precipitation rates in an active hydrothermal sulphide deposit on the Mid-Atlantic Ridge, Geology, 24, 1147-1150.

Jones, M. T. (Ed.) (2003), GEBCO Digital atlas: Centenary edition of the IHO/IOC General bathymetric chart of the oceans, Natl. Environ. Res. Counc., Swindon, U.K.

Jones, R. H., and R. C. Stewart (1997), A method for determining significant structures in a cloud of earthquakes, J. Geophys. Res., 102(B2), 8245-8254.

Johnson, H. P., M. Hutnak, R. P. Dziak, C. G. Fox, I. Urcuyo, J. P. Cowen, J. Nabelek, C. Fisher (2000), Earthquake-induced changes in a hydrothermal system on the Juan de Fuca mid-ocean ridge, Nature, 407, 174-177.

Julian, B. R., G. R. Foulger, and F. Monastero (2007), Microearthquake moment tensors from the Coso Geothermal area, in Proceedings, Thirty-Second Workshop on Geothermal Reservoir Engineering, Paper SGP-TR- 183, Stanford Univ., Stanford, Calif.

Karson, J. A., and P. A. Rona (1990), Block-tilting, transfer faults, and structural control of magmatics and hydrothermal processes in the TAG area, Mid- Atlantic Ridge $26^{\circ}$ N, Geological Society of America Bulletin, 102, 1635-1645. 
Kedar, S., and H. Kanamori (1998), Bubble collapse as the source of tremor at Old Faithful Geyser, J. Geophys. Res., 103(B10), 24283-24299.

Kieffer, S. W., and J. M. Delany (1979), Isentropic decompression of fluids from crustal and mantle pressures, J. Geophys. Res., 84(B4), 1611, doi:10.1029/JB084iB04P01611.

Kieffer, S. W. (1984), Seismicity at Old Faithful Geyser: An isolated source of geothermal noise and possible analogue of volcanic seismicity, J. Volcanol. Geotherm. Res., 22, 59-95.

Kleinrock, M. C., and S. E. Humphris (1996), Structural control on seafloor hydrothermal activity at the TAG active mound, Nature, 382, 149-153.

Knapp, R. B., and J. E. Knight (1977), Differential thermal expansion of pore fluids: Fracture propagation and microearthquake production in hot pluton environments, J. Geophys. Res., 82(17), 2515-2522.

Lalou, C., G. Thompson, M. Arnold, E. Brichet, E. Druffel, and P. A. Rona (1990), Geochronology of TAG and Snake Pit hydrothermal fields, Mid- Atlantic Ridge: Witness to a long and complex hydrothermal history, Earth Planetary Science Letters, 97, 113-128.

Lalou, C., J. L. Reyss, E. Brichet, M. Arnold, G. Thompson, Y. Fouquet, and P. A. Rona (1993), New age data for Mid-Atlantic Ridge hydrothermal sites: TAG and Snakepit geochronology revisited, J. Geophys. Res., 98, 9705-9713.

Lalou, C., J. L. Reyss, and E. Brichet (1998), Age of sub-bottom sulfide samples at the TAG active mound, in Proceedings of the Ocean Drilling Program, Scientific Results, vol. 158, edited by P. M. Herzig, S. E. Humphris, et al., pp. 111-117, College Station, Texas, Ocean Drilling Program.

Li, J., H. Zhang, H. Sadi Kuleli, and M. N. Toksoz (2011), Focal mechanism determination using high-frequency waveform matching and it sapplication to small magnitude induced earthquakes, Geophys. J. Int. 184, 1261-1274.

Lowell, R. P., and Y. Yao (2002), Anhydrite precipitation and the extent of hydrothermal recharge zones at ocean ridge crests, J. Geophys. Res., 107(B9), 2182, doi: 10.1029/2001JB001289.

Lowell, R. P., Yao, Y., and L. N. Germanovich (2003), Anhydrite precipitation and the relationship between focused and diffuse flow in seafloor hydrothermal systems, J. Geophys. Res., 108(B9), 2424, doi:10.1029/2002JB002371. 
Lokmer, I., and C. J. Bean (2010), Properties of the near-field term and its effect on polarization analysis and source locations of long-period (LP) and very-longperiod (VLP) seismic events at volcanoes, J. Volcanol. Geotherm. Res., 192, 3547, doi:10.1016/j.jvolgeores.2010.02.008.

Ludwig, R. J., G. J. Iturrino, and P. A. Rona (1998), 23. Seismic velocity-porosity relationship of sulfide, sulfate, and basalt samples from the TAG hydrothermal mound, in Proceedings of the Ocean Drilling Program, Scientific Results, vol. 158, edited by P. M. Herzig, S. E. Humphris, et al., pp. 313-328, College Station, Texas, Ocean Drilling Program.

Majer, E. L., and T. V. McEvilly (1979), Seismological investigations at the Geysers Geothermal Field, Geophysics, 44, 246-269.

Mangriotis, M.-D., J. W. Rector, III, and E. F. Herkenhoff (2011), Effects of the nearfield on shallow seismic studies, Geophysics, 76(1), B9-B18, doi:10.1190/1,3517512.

McDonald, M.A., J.A. Hildebrand and S.C. Webb. Blue and fin whales observed on a seafloor array in the Northeast Pacific. J. Acoust. Soc. Am. 98(2);712-721. (1995).

McGregor, B. A., and P. A. Rona (1975), Crest of Mid-Atlantic Ridge at $26^{\circ} \mathrm{N}, J$. Geophys. Res., 80, 3307-3314.

McGregor, B. A., C. G. A. Harrison, J. W. Lavelle, and P. A. Rona (1977), Magnetic anomaly pattern on the Mid-Atlantic Ridge crest at $26^{\circ} \mathrm{N}$, J. Geophys. Res., 82, 231-238.

Miller, A. D., G. R. Foulger, and B. R. Julian (1998), Non-double-couple earthquakes: 2. Observations, Reviews of Geophysics, 36(4), 551-568.

Noiriel, C., F. Renard, M.-L. Doan, J.-P. Gratier (2010), Intense fracturing and fracture sealing induced by mineral growth in porous rocks, Chemical Geology, 269, 197 209, doi: 10.1016/j.chemgeo.2009.09.018.

Palliser, C., and R. McKibben (1998), A model for deep geothermal brines, II:

Thermodynamic properties - Density, Transport in Porous Media, 33, 129-154.

Pearson, C. (1982), Parameters and a magnitude moment relationship from small earthquakes obseruved during hydraulic fracturing experiments in crystalline rocks, Geophys. Res. Lett., 9, 404-407. 
Percival, D. B., and A. T. Walden (1993), Spectral analysis for physical applications: Multitaper and conventional univariate techniques, Cambridge University Press, Cambridge, U. K.

Prejean, S. G., and W. L. Ellsworth (2001), Observations of earthquake source parameters at $2 \mathrm{~km}$ depth in the Long Valley Caldera, Eastern California, Bull. Seis. Soc. Amer., 91(2), 165-177.

Rayleigh (1917), On the pressure developed in a liquid during the collapse of a spherical bubble, Philos. Mag., 34, 94-98.

Robie, R. A., and B. S. Hemingway (1995), Thermodynamic properties of minerals and related substances at $298.15 \mathrm{~K}$ and 1 bar $\left(10^{5}\right.$ Pascals) pressure and at higher temperatures, U. S. Geological survey Bulletin, $461 \mathrm{pp}$.

Roman, C. N., and H. Singh (2005), Self consistent bathymetric mapping from robotic vehicles in the deep ocean, Ph. D. thesis, Joint Program in Applied Ocean Science and Engineering, Massachusetts Institute of Technology Dept. of Ocean Engineering, Woods Hole Oceanographic Institution, Campridge, Massachusetts, USA.

Rona, P. A., B. A. McGregor, P. R. Betzer, G. W. Bolger, and D. C. Krause (1975), Anomalous water temperatures over Mid-Atlantic Ridge crest at $26^{\circ} \mathrm{N}$, Deep Sea Research, 22, 611-618.

Rona, P. A. (1984), Hydrothermal mineralization at seafloor spreading centers, EarthScience Reviews, 20, 1-104.

Rona, P. A., G. Klinkhammer, T. A. Nelsen, J. H. Trefry, and H. Elderfield (1986), Black smokers, massive sulphides, and vent biota at the Mid-Atlantic Ridge, Nature, $321,33-37$.

Rona, P. A., and K. G. Speer (1989), An Atlantic Hydrothermal Plume: Trans-Atlantic Geotraverse (TAG) Area, Mid-Atlantic Ridge Crest Near $26^{\circ} \mathrm{N}$, J. Geophys. Res., $94,13,879-13,893$.

Rona, P. A., Y. A. Bogdanov, E. G. Gurvich, A. Rimski-Korsakov, A. M. Sagalevitch, M. D. Hannington, and G. Thompson (1993a), Relict hydrothermal zones in the TAG hydrothermal field, Mid-Atlantic Ridge $26^{\circ} \mathrm{N}, 45^{\circ} \mathrm{W}$, J. Geophys. Res., 98 , 9715-9730. 
Rona, P. A., M. D. Hannington, C. V. Raman, G. Thompson, M. K. Tivey, S. E. Humphris, C. Lalou, and S. Petersen (1993b), Active and relict seafloor hydrothermal mineralization at the TAG hydrothermal field, Mid-Atlantic Ridge, Economic Geology, 18, 1989-2017.

Ross, A., G. R. Foulger, and B. R. Julian (1996), Non-double-couple earthquake mechanisms at The Geysers geothermal area, California, Geophys. Res. Lett., 23(8), 877-880.

Rubin, A. M. (1992), Dike-induced faulting and graben subsidence in volcanic rift zones, J. Geophys. Res., 97(B2),1839-1858.

Rubin, A. M., and D. Gillard (1998), Dike-induced earthquakes: Theoretical considerations, J. Geophys. Res., 103(B5), 10017-10030.

Scherer, G. W. (1999), Crystallization in pores, Cement and Concrete Research, 29, 1347-1358.

Scherer, G. W. (2004), Stress from crystallization of salt, Cement and Concrete Research, 34, 1613-1624, doi:10.1016/j.cemconres.2003.12.034.

Scholtz, C. H. (2002), The Mechanics of Earthquakes and Faulting, Cambridge University Press, Cambridge, U. K.

Scott, R. B., P. A. Rona, and B. A. McGregor (1974a), The TAG hydrothermal field, Nature, 251, 301-302.

Scott, M. R., R. B. Scott, P. A. Rona, L. W. Butler, and A. J. Nalwalk (1974b), Rapidly accumulating manganese deposit from the median valley of the Mid-Atlantic ridge, Geophys. Res. Lett., 1, 355-358.

Seyfried, W. E., Jr. (1987), Experimental and theoretical constraints on hydrothermal alteration processes at mid-ocean ridges, Ann. Rev. Earth Planet. Sci., 15, $317-$ 335 .

Š́lený, J., D. P. Hill, L. Eisner, and F. H. Cornet (2009), Non-double-couple mechanisms of microearthquakes induced by hydraulic fracturing, J. Geophys. Res., 114(B08309), doi:10.1029/2008JB005987.

Steiger, M. (2005a), Crystal growth in porous materials -I: The crystallization pressure of large crystals, J. of Crystal Growth, 282, 455-469, doi:10.1016/j.jcrysgro.2005.05.007. 
Steiger, M. (2005b), Crystal growth in porous materials - II: Influence of crystal size on the crystallization pressure, J. of Crystal Growth, 282, 470:481, doi: 10.1016/j.jcrysgro.2005.05.008.

Sohn, R. A., J. A. Hildebrand, S. C. Webb, and C. G. Fox (1995), Hydrothermal microseismicity at the Megaplume Site on the Southern Juan de Fuca Ridge, Bull. Seis. Soc. Amer., 85(3), 775-786.

Sohn, R., D. Fornari, K. Von Damm, J. Hildebrand, and S. Webb (1998), Seismic and hydrothermal evidence for a cracking event on the East Pacific Rise crest at $9^{\circ} 50$ ’N, Nature, 396, 159-161.

Sohn, R. A., J. A. Hildebrand, and S. C. Webb (1999), A microearthquake survey of the high-temperature vent fields on the volcanically active East Pacific Rise $\left(9^{\circ} 50^{\prime} \mathrm{N}\right)$, J. Geophys. Res., 104(B11), 25367-25377.

Sohn, R. A. (2007a), Stochastic analysis of exit fluid temperature records from the active TAG hydrothermal mound (Mid-Atlantic Ridge, $26^{\circ} \mathrm{N}$ ): 1 . Modes of variability and implications for subsurface flow, J. Geophys. Res., 112: B07101, doi:10.1029/2007JB004435.

Sohn, R. A. (2007b), Stochastic analysis of exit fluid temperature records from the active TAG hydrothermal mound (Mid-Atlantic Ridge, $26^{\circ} \mathrm{N}$ ): 2. Hidden Markov models of flow episodes, J. Geophys. Res., 112: B09102, doi:10.1029/2007JB004961.

Sohn, R. A., R. E. Thomson, A. B. Rabinovich, and S. F. Mihaly (2009), Bottom pressure signals at the TAG deep-sea hydrothermal field: Evidence for short-period, flowinduced ground deformation, Geophys. Res. Lett., 36, L19301, doi:10.1029/2009GL040006.

Song, F., H. S. Kuleli, M. N. Toksöz, E. Ay, and H. Zhang (2010), An improved method for hydrofracture-induced microseismic event detection and phase picking, Geophysics, 75(6),A47-A52, doi: 10.1190/1.3484716.

Teagle, D. A. H., J. C. Alt, H. Chiba, S. E. Humphris, A. N. Halliday (1998), Strontium and oxygen isotopic constraints on fluid mixing, alteration and mineralization in the TAG hydrothermal deposit, Chemical Geology, 149, 1-24.

Tivey, M. K., S. E. Humphris, G. Thompson, M. D. Hannington, and P. A. Rona (1995), Deducing patterns of fluid flow and mixing within the active TAG mound using mineralogical and geochemical data, J. Geophys. Res., 100, 12527-12555. 
Tivey, M. K., R. A. Mills, and D. A. H. Teagle (1998), Temperature and salinity of fluid inclusions in anhydrite as indicators of seawater entrainment and heating in the TAG active mound,, in Proceedings of the Ocean Drilling Program, Scientific Results, vol. 158, edited by P. M. Herzig, S. E. Humphris, et al., pp. 179-190, College Station, Texas, Ocean Drilling Program.

Tivey, M. A., H. Schouten, and M. C. Kleinrock (2003), A near-bottom magnetic survey of the Mid-Atlantic Ridge axis at $26^{\circ} \mathrm{N}$ : Implications for the tectonic evolution of the TAG segment, J. Geophys. Res., 108, 2277, doi:10.1029/2002JB001967.

Thompson, G., M. J. Mottl, and P. A. Rona (1985), Morphology, mineralogy, and chemistry of hydrothermal deposits from the TAG area, $26^{\circ} \mathrm{N}$ Mid-Atlantic Ridge, Chemical Geology, 49, 243-257.

Tolstoy, M., F. Waldhauser, D. R. Bohnenstiehl, R. T. Weekly, and W.-Y. Kim (2008), Seismic identification of along-axis hydrothermal flow on the East Pacific Rise, Nature, 451, 181-185, doi:10.1038/nature06424.

Vandemeulebrouck, V., P. Roux, P. Gouédard, A. Legaz, A. Revil, A. W. Hurst, A. Boleve, and A. Jardani (2010), Application of acoustic noise and self-potential localization techniques to a buried hydrothermal vent (Waimangu Old Geyser site, New Zealand), Geophys. J. Int., 180, 883-890, doi: 10.1111/j.1365246X.2009.04454.X

Vermilye, J. M. and C. H. Scholz (1995), Relation between vein length and aperture, J.of Structural Geology, 17(3), 423-434.

Walder, J. and B. Hallet (1985), A theoretical model of the fracture of rock during freezing, Geol. Soc. Amer. Bull., 96, 336-346.

Webb, S. C. (1992), The equilibrium oceanic microseism spectrum. J. Acoust. Soc. Amer., 92 (4), 2141-2158.

Webb, S. C. and W. C. Crawford (1999), Long-period seafloor seismology and deformation under ocean waves, Bull. Seis. Soc. Amer., 89(6), 1535-1542.

White, D. E., L. J. P. Buffler, and A. H. Truesdell (1971), Vapor-dominated hydrothermal systems compared with hot-water systems, Economic Geology, 66, 75-97.

White, S. N., S. E. Humphris, and M. C. Kleinrock (1998), New observations on the distribution of past and present hydrothermal activity in the TAG area of the Mid-

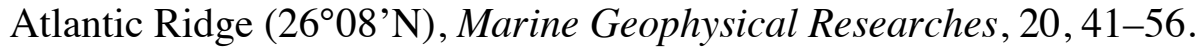


Wichers, S., H. Singh, and R. Reves-Sohn (2005), Verification of numerical models for hydrothermal plume water through field measurements at TAG, Masters thesis, Massachusetts Institute of Technology and Woods Hole Oceanographic Institution, Cambridge, Massachusetts, USA.

Wilcock, W. S. D., and D. R. Toomey (1991), Estimating hypocentral uncertainties for marine microearthquake surveys: A comparison of the generalized inverse and grid search methods, Marine Geophysical Researches, 13, 161-171.

You, C. F., and M. J. Bickle (1998), Evolution of an active sea-floor massive sulphide deposit, Nature, 394, 668-671.

Zonenshain, L. P., M. I. Kuzmin, A. P. Lisitsin, Y. A. Bogdanov, and B. V. Baranov (1989), Tectonics of the Mid-Atlantic rift valley between the TAG and MARK areas $\left(26-24^{\circ} \mathrm{N}\right)$ : Evidence for vertical tectonism, Tectonophysics, 159, 1-23. 
Figure 1. A) Area map of the Mid-Atlantic Ridge at $26^{\circ} \mathrm{N}$ and the TAG hydrothermal field [Jones, 2003; Bird, 2003]. B) Bathymetry of the TAG segment with microearthquake epicenters (black dots) depicting a dome-shaped detachment fault [deMartin et al., 2007]. Its extensional hanging wall hosts relict and active hydrothermal mounds [Tivey et al., 2003]. The locations of relict and shimmering hydrothermal mounds are marked by black and white circles, respectively, and the TAG active mound is at the white star.
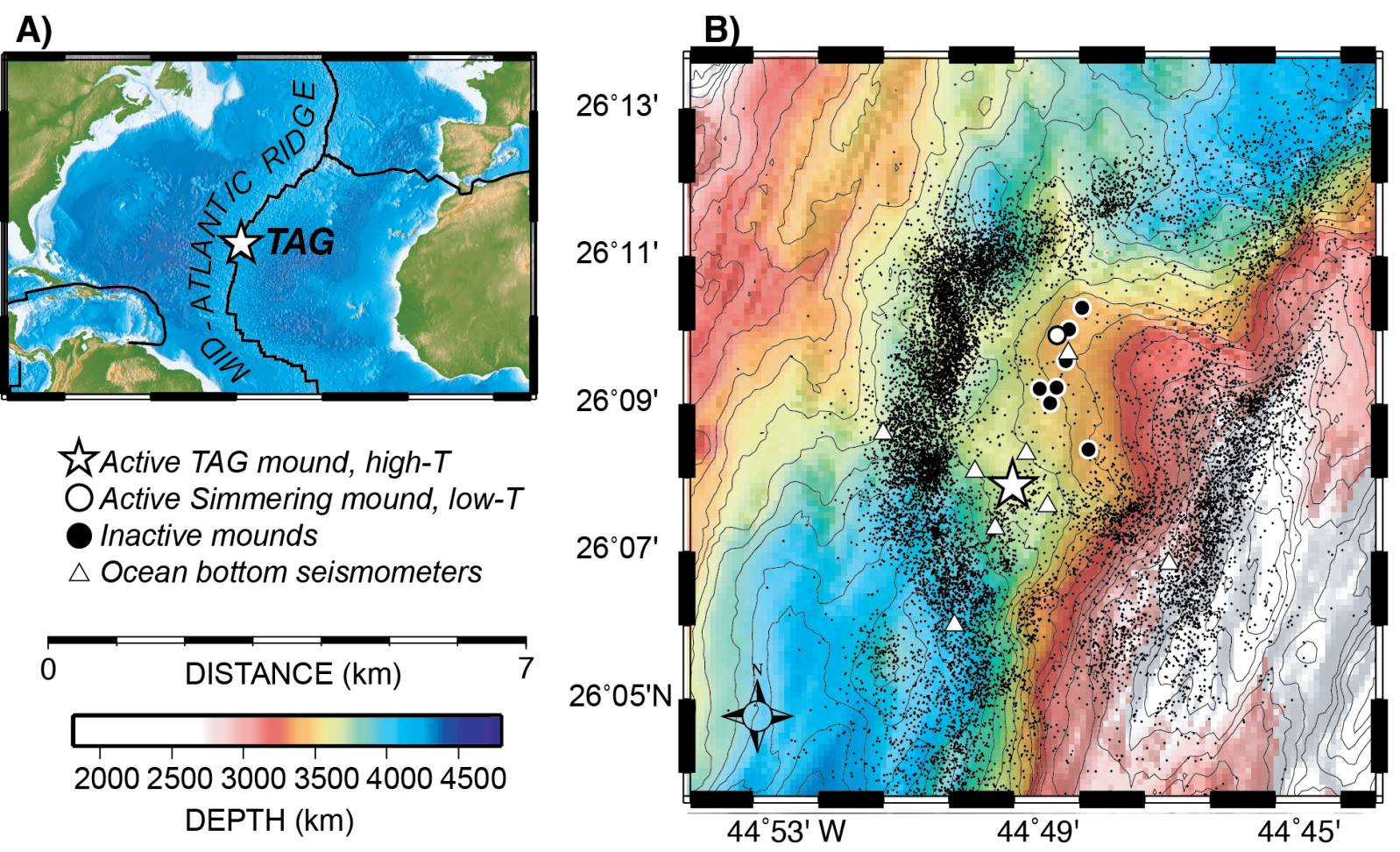

今Active TAG mound, high-T OActive Simmering mound, low- $T$ Inactive mounds $\triangle$ Ocean bottom seismometers

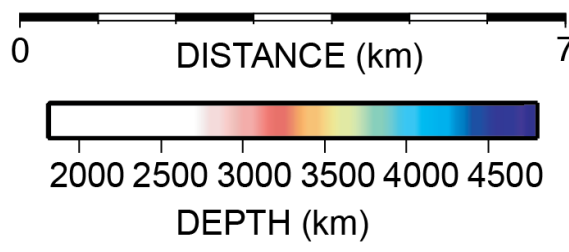


Figure 2. Microbathymetry of the TAG active mound [White et al., 1998; Roman and Singh, 2007]. The surface expression of the $\sim 200 \mathrm{~m}$ diameter mound is indicated by the outermost dashed white circle. High-temperature discharge $\left(>360^{\circ} \mathrm{C}\right)$ during the time period of the STAG experiment was focused at the Black Smoker Complex (BSC), whereas low-temperature $\left(<100^{\circ} \mathrm{C}\right)$ discharge was observed at discrete locations across the upper terrace [Sohn, 2007a]. Locations of the 5 OBSs on the periphery of the mound are denoted by triangles. STIR-12 (black triangle) failed 77 days into the experiment. Local fault/fissure orientations show great variation [Bohnenstiehl and Kleinrock, 2000].

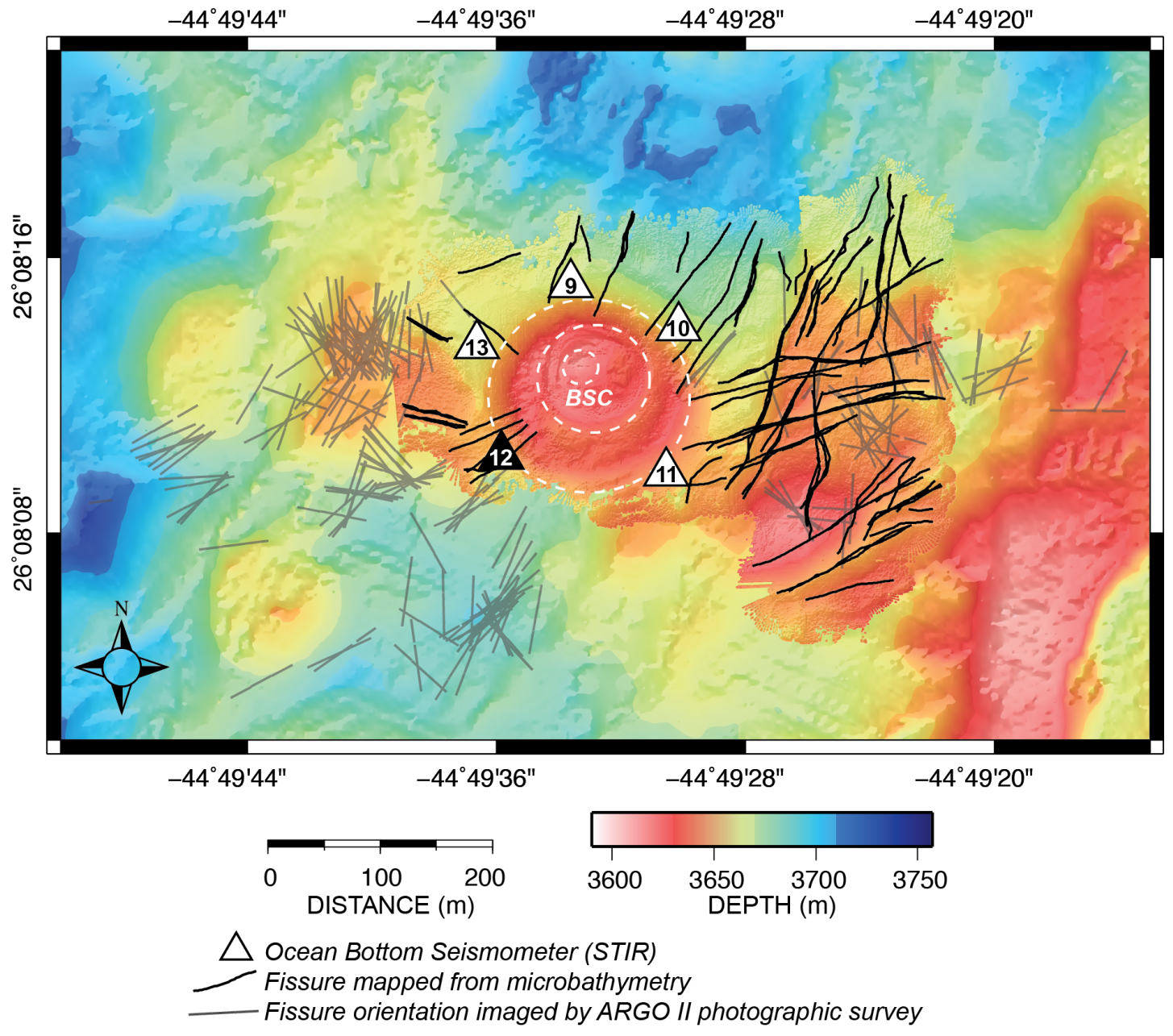


Figure 3. Cumulative event count in time for events arriving on four or more OBSs $(\mathrm{n}=$ 32,078 events). Event rate is 243 events per day prior to the failure of STIR-12 77 days into the study, at which time event rate decreases to 128 events per day. Whale noise in the area begins in November, masking some microearthquake events and decreasing the observed event rate to 97 events per day.

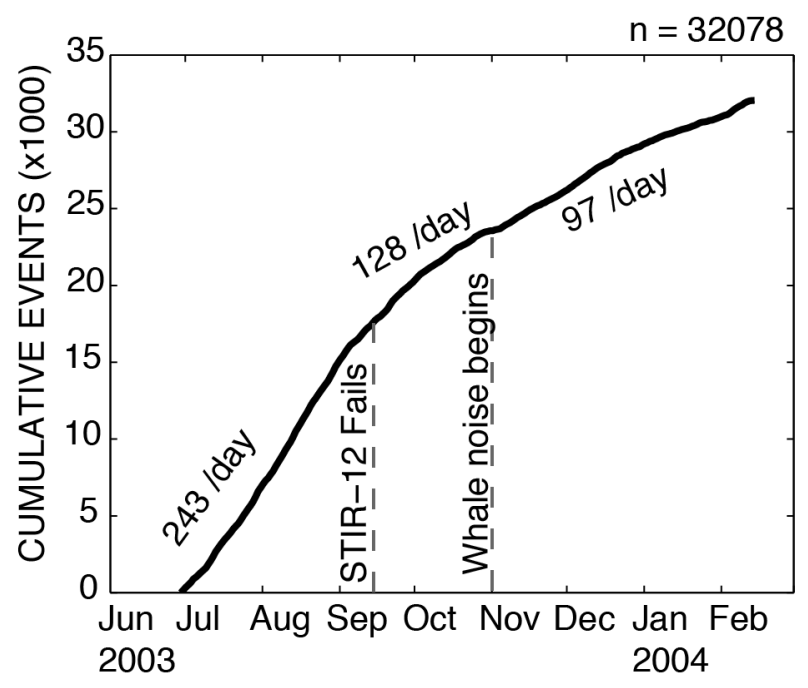


Figure 4. Multitaper spectral estimates $(\mathrm{NW}=5)$ of $(\mathrm{A})$ the microearthquake catalog as a point process (10 minute bins), (B) pressure gauge data, and (C) predicted solid earth tide loading show a lack of tidal influence on the microearthquake catalog. Major tidal constituents (e.g. $\mathrm{O}_{1}, \mathrm{~K}_{1}, \mathrm{M}_{2}, \mathrm{~S}_{2}, \mathrm{MK}_{3}, \mathrm{M}_{4}$ ) are labeled in blue lines [Foreman, 1977]. There are no highly coherent periodicities (with threshold $\mathrm{C}^{2}>0.6$ ) between the (D) microearthquake catalog and pressure gauge data nor between the (E) microearthquake catalog and solid earth tide. Most coherences fall below the $95 \%$ level of significance denoted by a red line (i.e. coherences are not significantly higher than zero).
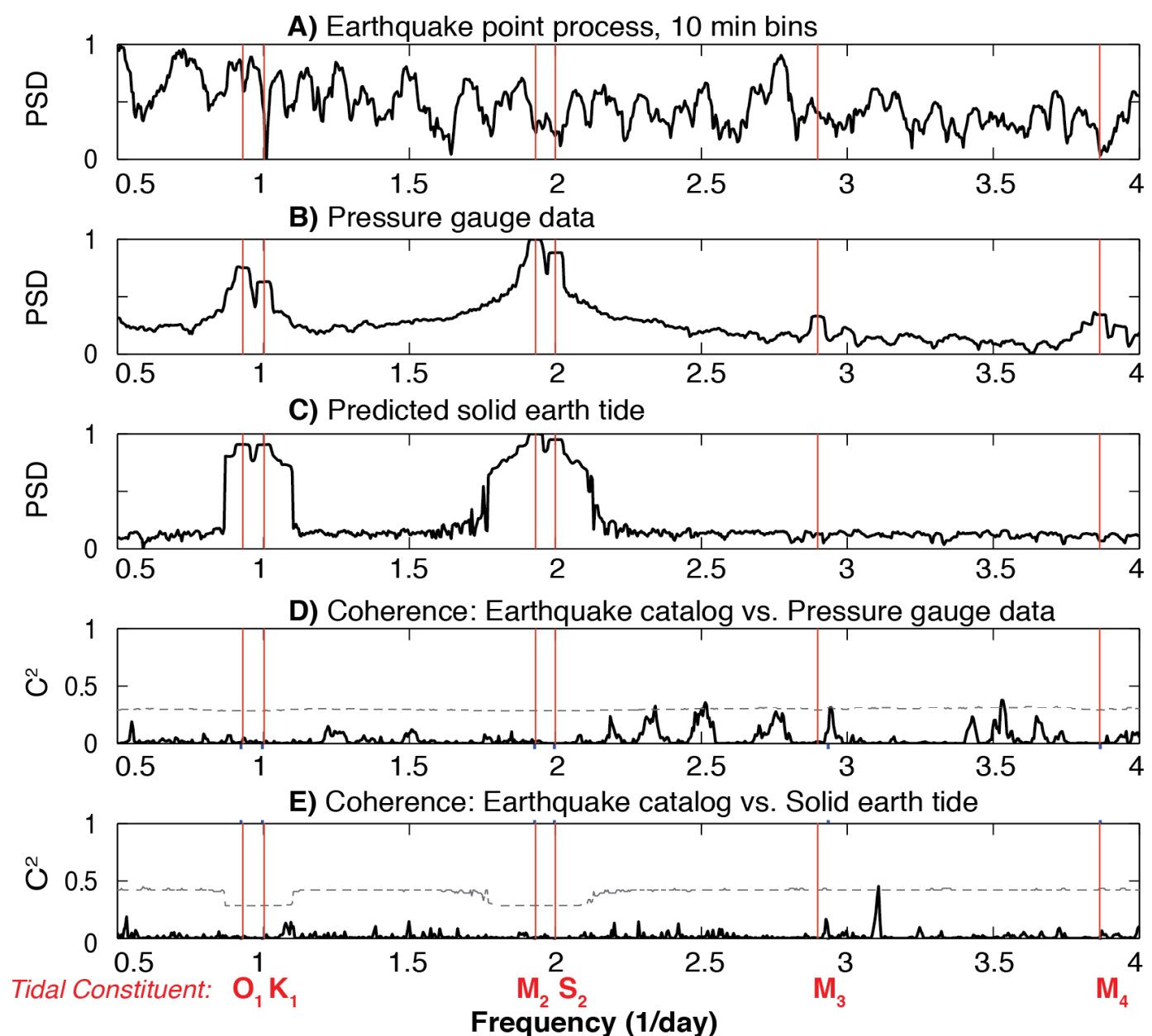
Figure 5. Magnitude histogram of 6,207 events with hypocenter estimate root mean square errors less than $20 \mathrm{~ms}$. Mean magnitude is -0.95 and mean log-moment is 14.57 (log dyne $\mathrm{cm}$ ).

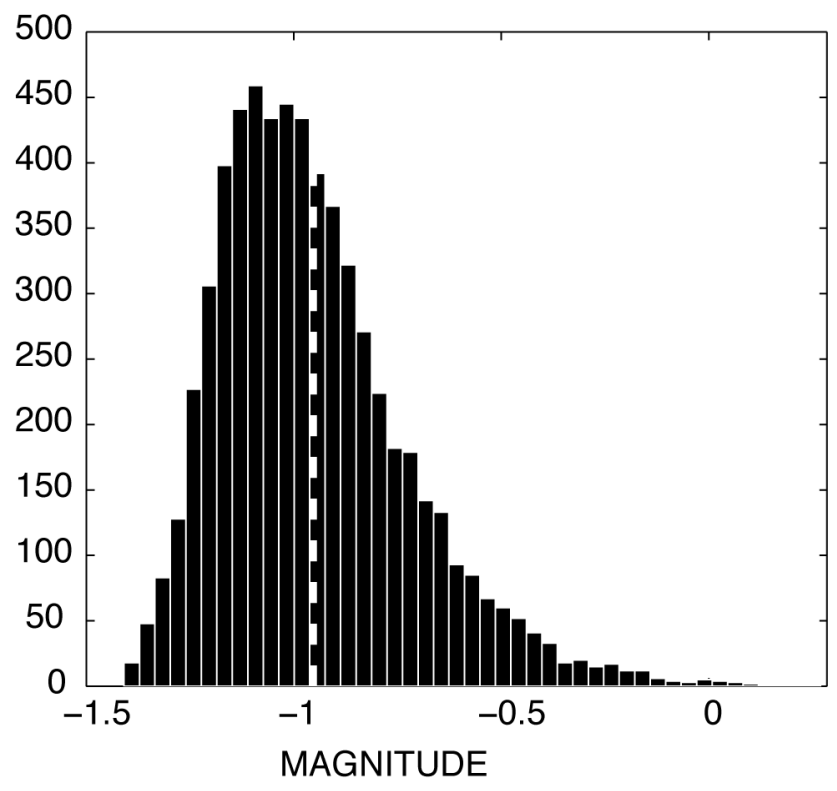


Figure 6. Waveforms and spectra of 3 microearthquake events. Event waveforms are from vertical channels of the 5 OBSs and have different velocity scales to better convey the diversity of waveforms across the network. Event power spectral density, which is calculated using the multi-taper method with $\mathrm{NW}=4$, is shown for each waveform. Events have single-phase arrivals and very different waveforms across the network suggestive of non-double couple sources whose paths are affected by local scattering. See Figures 8 and 9 for estimated hypocenters (labeled EX1, EX2, and EX3).
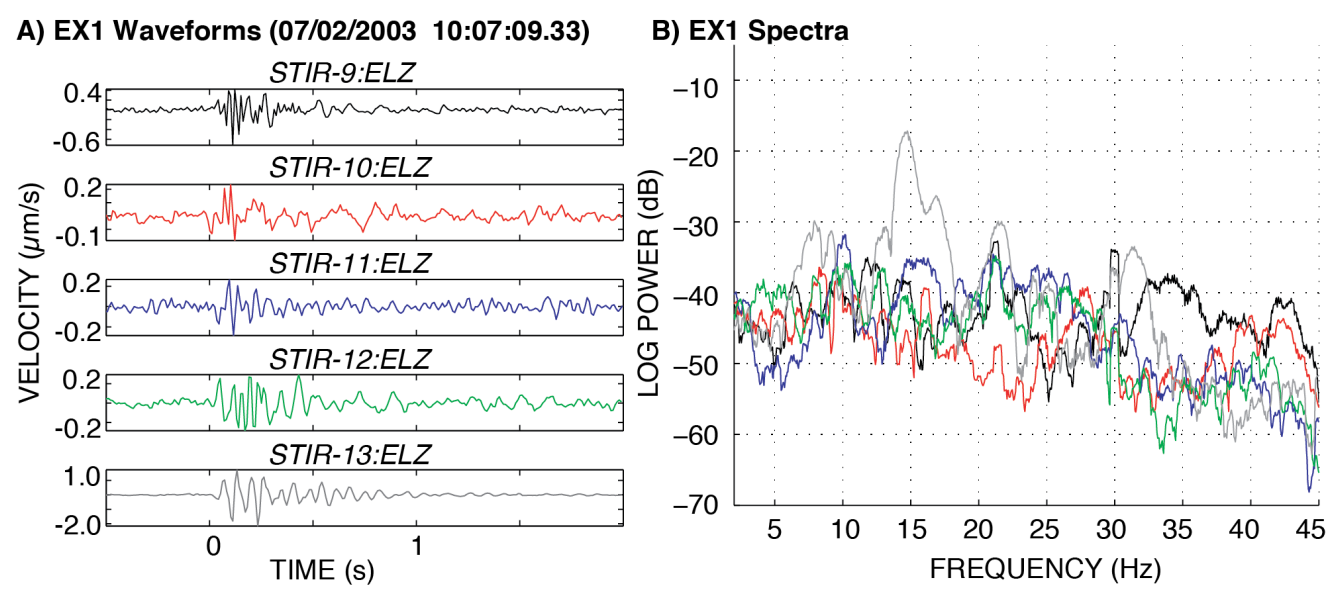

C) EX2 Waveforms (07/02/2003 13:49:41.00)

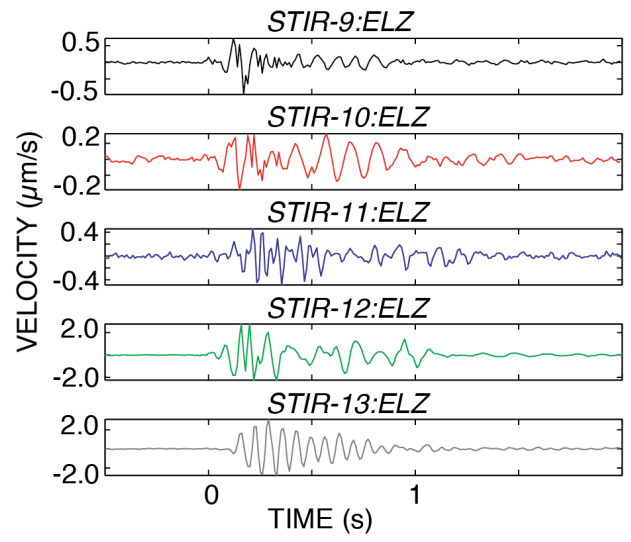

D) EX2 Spectra

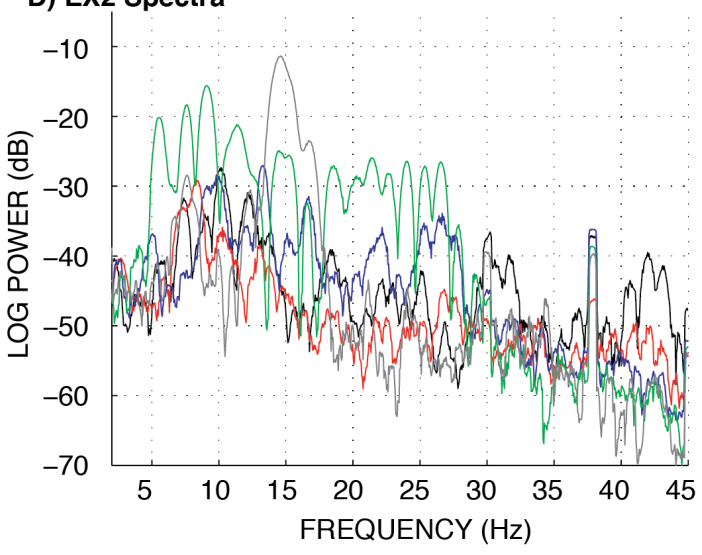

E) EX3 Waveforms (07/02/2003 20:19:47.68)
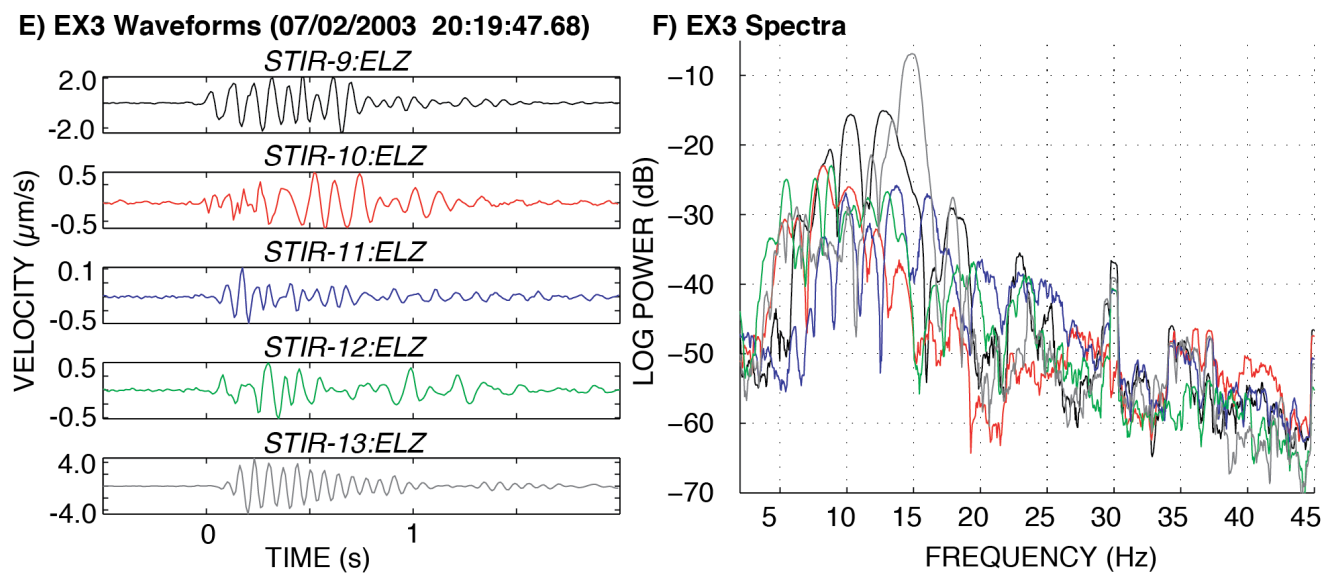
Figure 7. RMS histogram shows the 17,487 events arriving on four or more OBSs with hypocenter estimate root mean square (RMS) errors less than 200 milliseconds. Epicenter and hypocenter maps depict the 6,207 events with hypocenter estimates with RMS errors less than $20 \mathrm{~ms}$ (dashed white line).

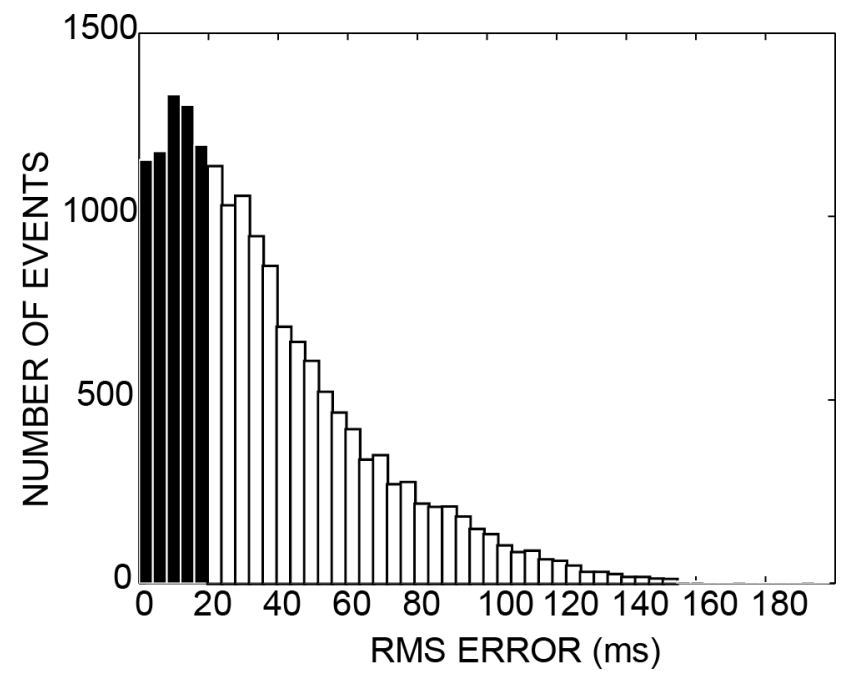


Figure 8. A) Bathymetric map of 6,207 epicenters with average 1- $\sigma$ confidence ellipses $(+/-\sim 400 \mathrm{~m})$. Depth sections (no vertical exaggeration) across (B) a west-to-east plane and $(\mathbf{C})$ a south-to-north plane show the shallow extent of event hypocenters, which cluster in a cloud in the top $125 \mathrm{~m}$ of crust (blue dashed lines). Hypocenter and epicenter locations of example events (Figure 6) are labeled EX1, EX2, and EX3.
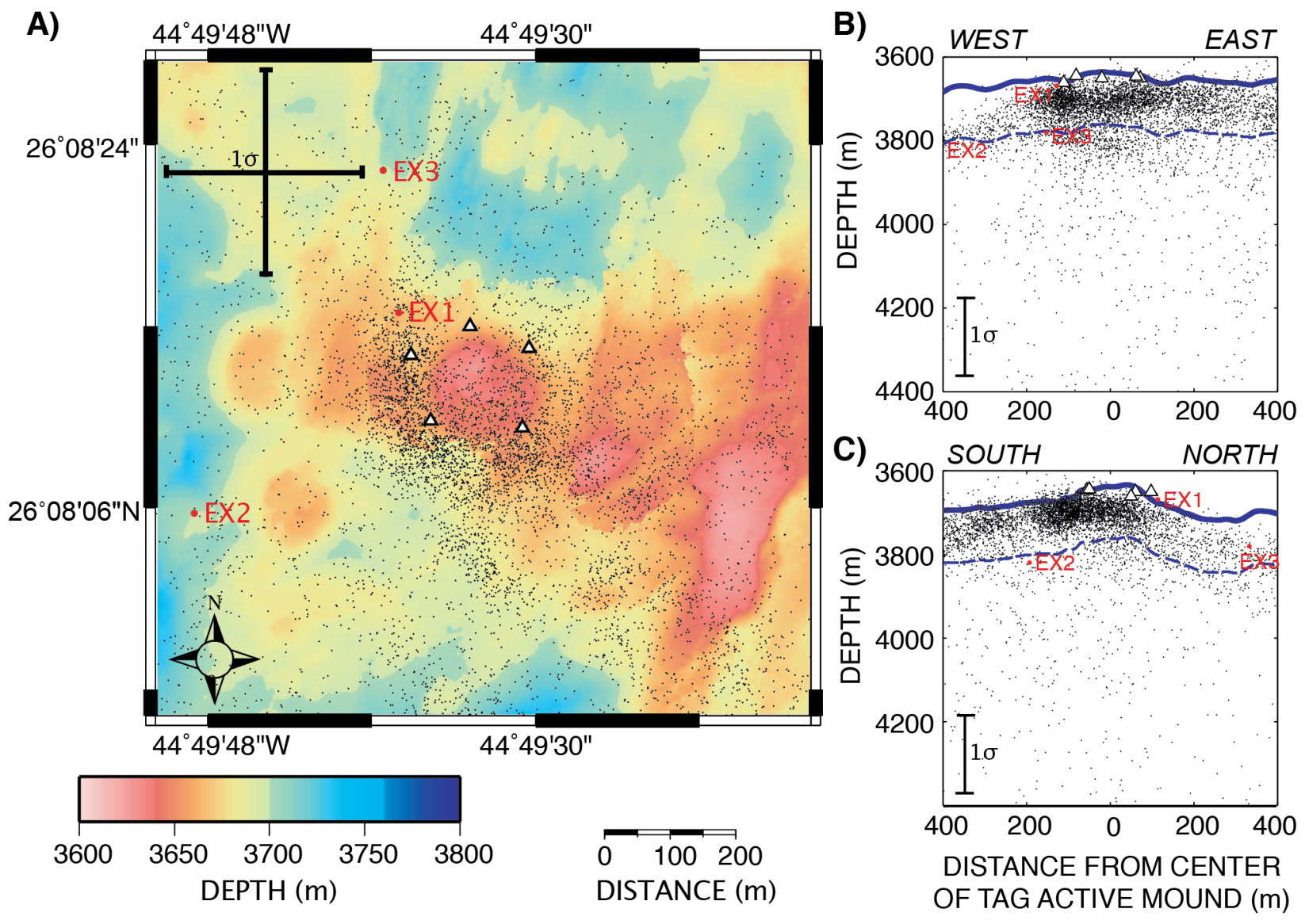
Figure 9. A) Bathymetric map of 6,207 epicenters after collapse along their confidence ellipses [e.g. Jones and Stewart, 1997]. Depth sections (no vertical exaggeration) across (B) a west-to-east plane and (C) a south-to-north plane show the shallow extent of event hypocenters, which cluster in a cloud in the top $125 \mathrm{~m}$ of crust (blue dashed lines). Hypocenter and epicenter locations of example events (Figure 6) are labeled EX1, EX2, and EX3.
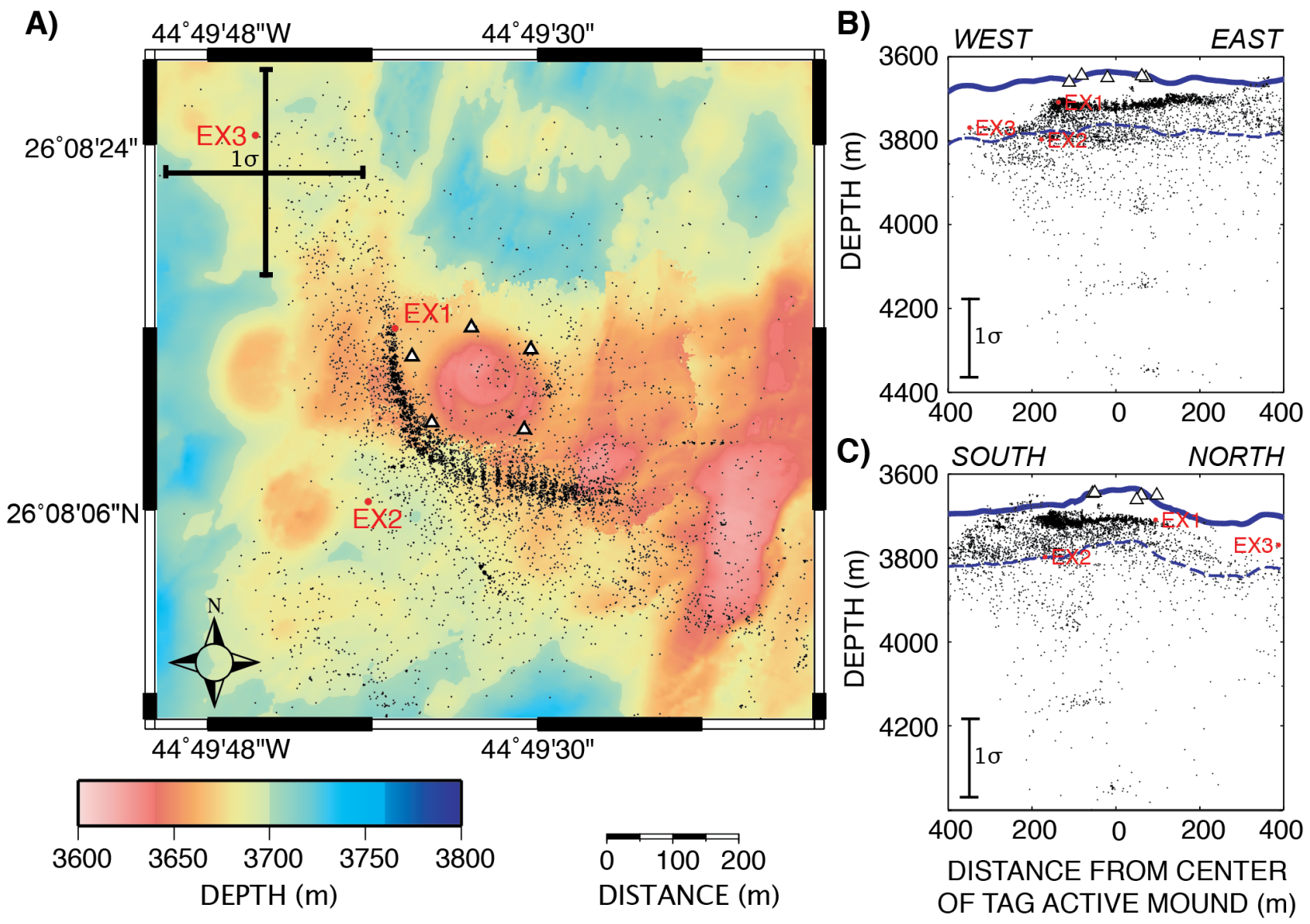
Figure 10. Density map of 6,207 epicenters prior to applying the collapsing method. Note that the results of the collapsing method (Figure 9) serve to highlight the zone of densest seismicity on the south and west flanks of the mound.

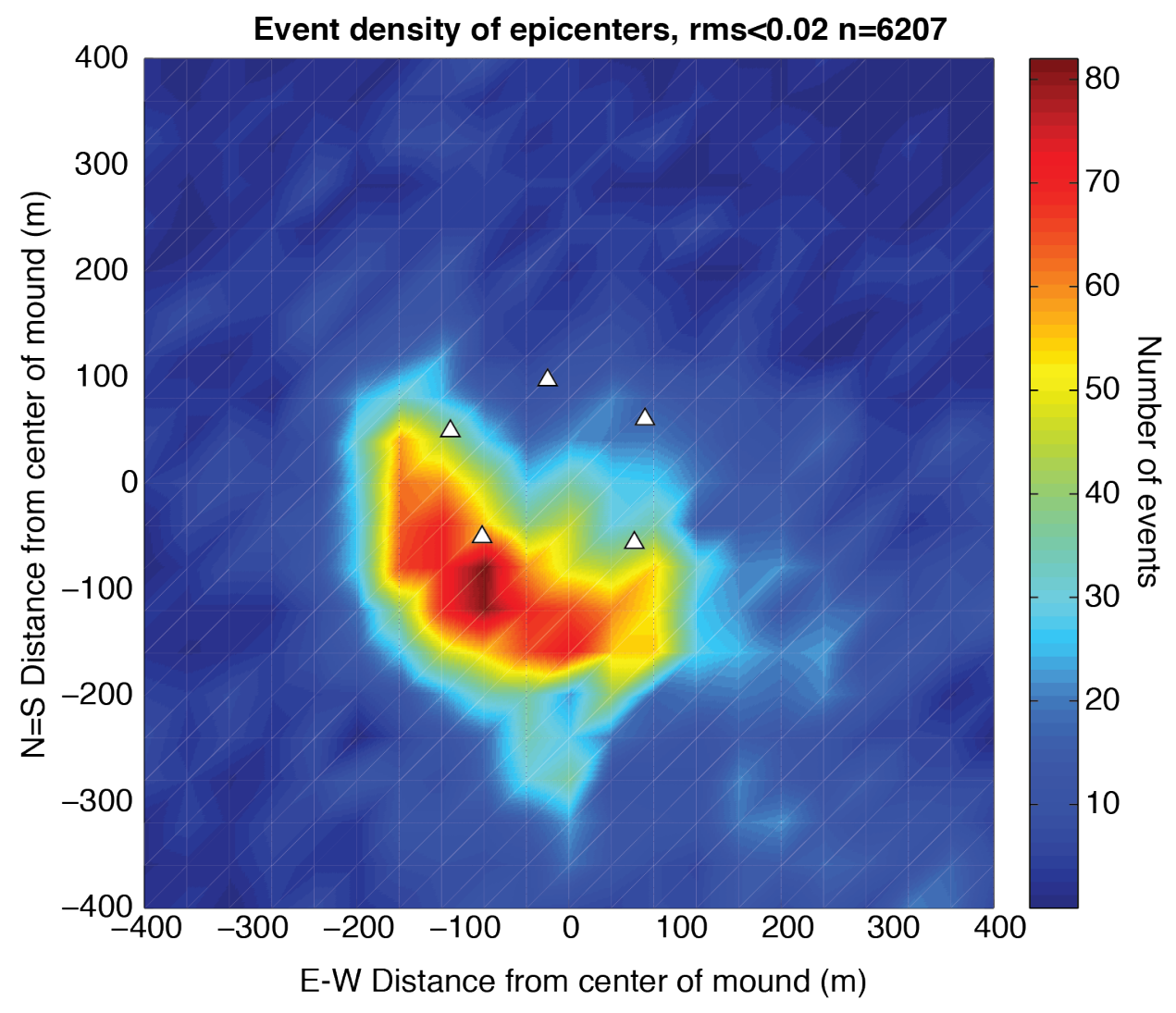

$\triangle$ ocean bottom seismometer 
Figure 11. A) A photograph and (B) sketch of a massive to semi-massive, brecciated pyrite associated with vein-related, pyrite-anhydrite breccias collected on ODP Leg 158, Hole 975C (158-957C-11N-2) (Figure 16 of Humphris et al., [1996]). Angular clasts of fine-grained, massive pyrite occur along the edges of the anhydrite veins and are extensively fractured. The section is collected from $\sim 33 \mathrm{mbsf}$ drilled from the upper terrace $\sim 20$ m southeast of the Black Smoker Complex.

A)

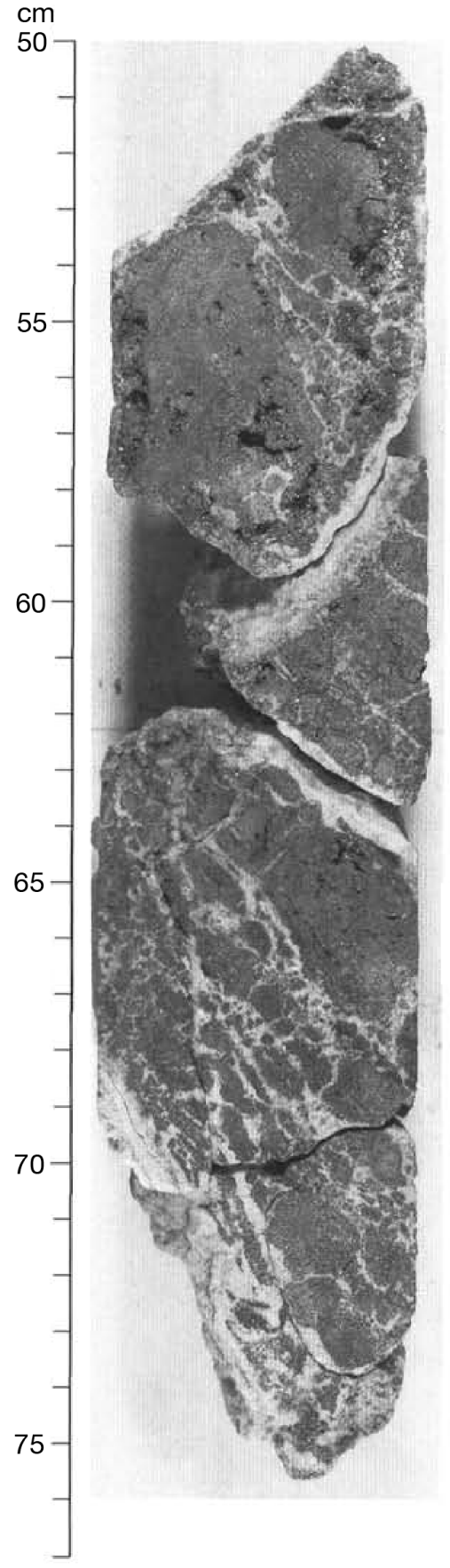

B)

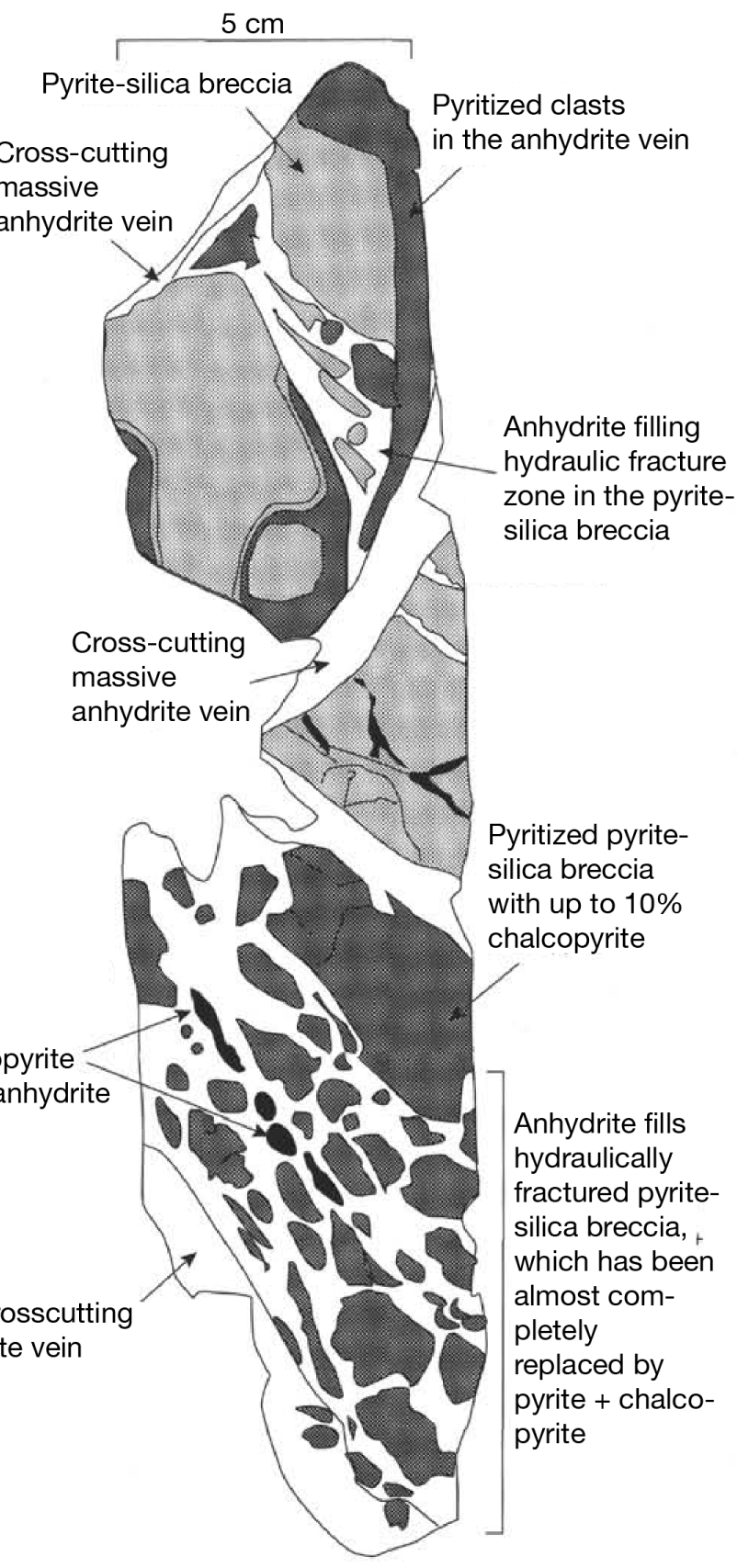


Figure 12. A) Body force representation for a mode I crack opening. Expansion is illustrated in the vertical direction. However no preferred orientation was clear from orientations of veins in drill cores, which had dips ranging from $0^{\circ}$ to $90^{\circ}$ [Humphris et al., 1996]. B) Diagram of a crack opening under tension in stockwork.

A)

(3)

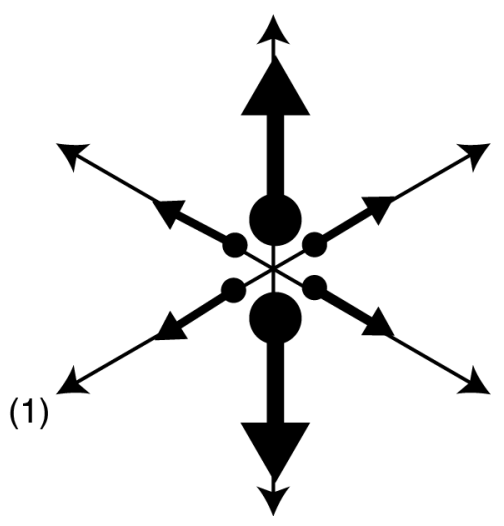

B)

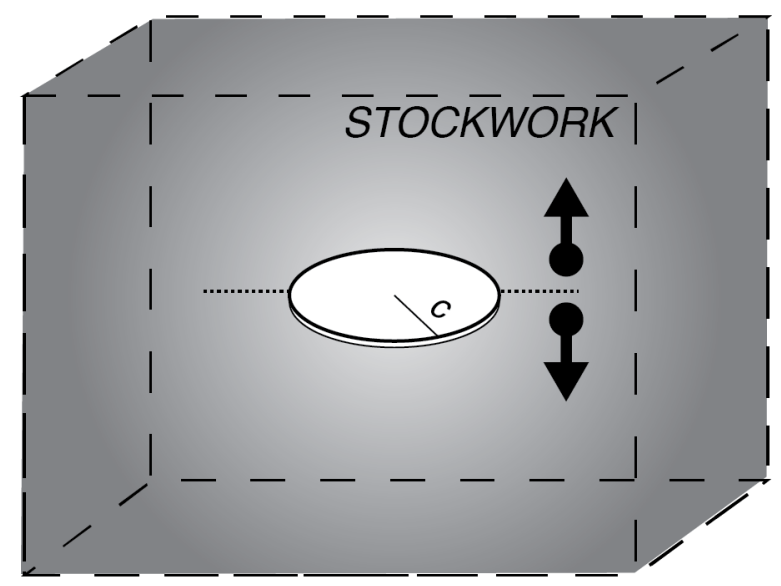

Figure 13. A plot of the stress drop and source volume required to generate microearthquakes of the range of moments observed (i.e. $10^{13}-10^{16}$ dyne-cm) in altered basalt. The dashed red lines mark confining pressure at $39 \mathrm{MPa}$ and differential pressure at $2.6 \mathrm{MPa}$.

Stress Drop vs. Source Volume for Altered Basalt

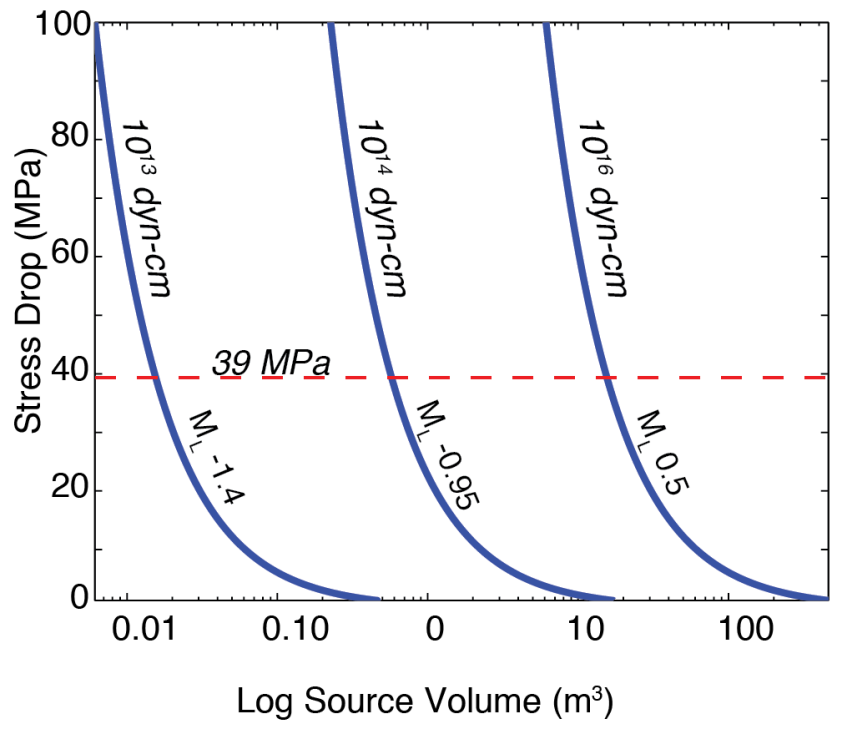


Figure 14. A depth section of 2,415 events located in a $200 \mathrm{~m}$ wide plane cutting north to south through the center of the TAG active mound shows a seismogenic zone focused to the south of the deposit and $<150 \mathrm{~m}$ below the seafloor. Many hypocenters lie within the anhydrite-rich zone and anhydrite-veined alteration zones of the TAG active mound [Humphris et al., 1995; Alt and Teagle, 1998]. A well-defined horizontal band of seismicity that likely marks a zone of reaction-driven cracking where secondary circulation recharge fuels the most intense anhydrite deposition. Comment about heat source

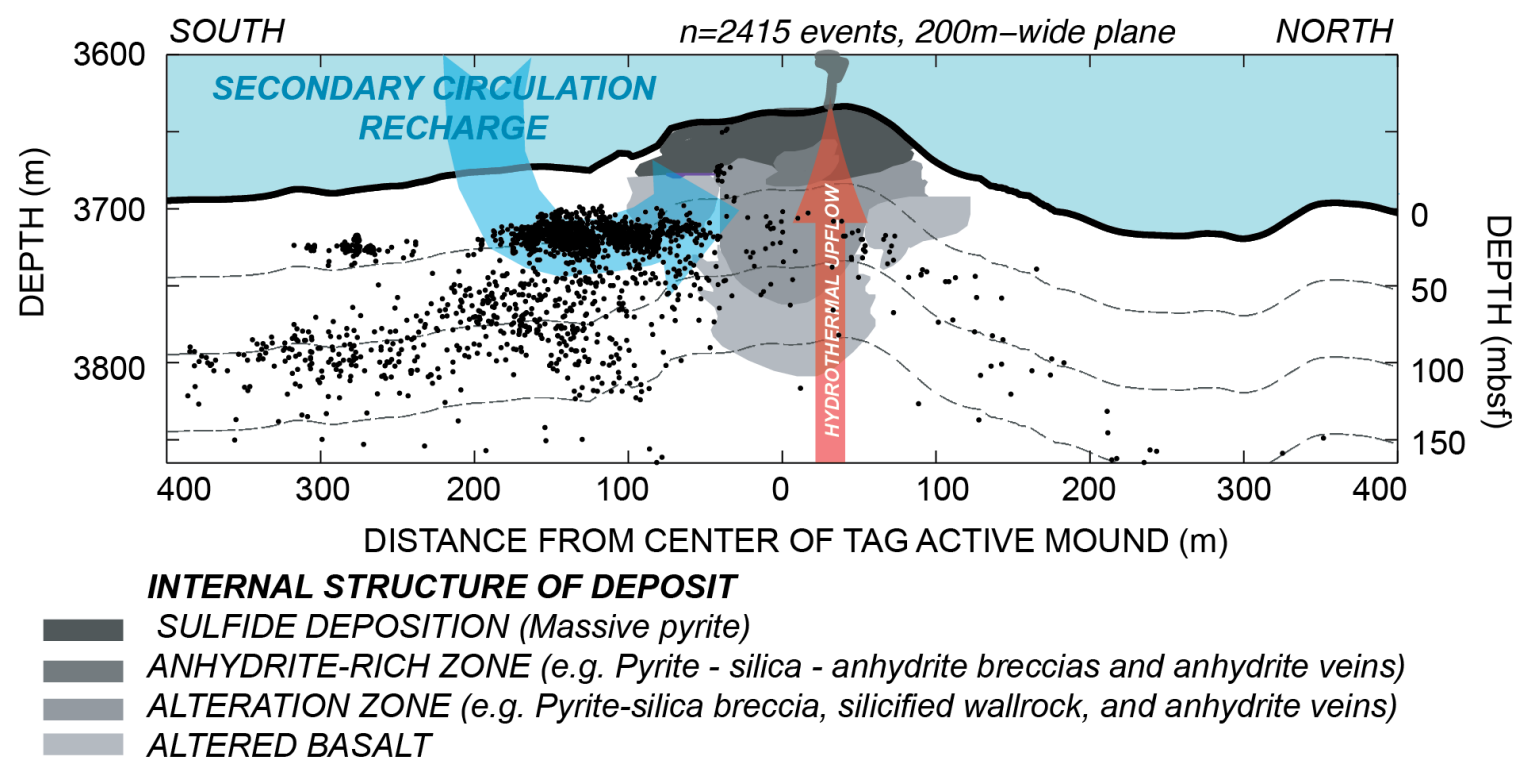




\title{
Chapter 4: Statistical assessment of the correlation between microearthquake activity and exit-fluid temperatures at the Trans- Atlantic Geotraverse active mound, Mid-Atlantic Ridge $\left(\mathbf{2 6}^{\circ} 08^{\prime} \mathbf{N}\right)$
}

\begin{abstract}
We use statistical methods to assess the impact of microearthquake activity on exit-fluid temperatures at the Trans-Atlantic Geotraverse active mound. Two microearthquake catalogs are derived from a 9-month deployment of ocean bottom seismometers at the TAG segment of the Mid-Atlantic Ridge during which exit-fluid temperature records were measured at discrete discharge sites on the upper terrace of the active mound. The 'segment-scale' catalog contains microearthquakes associated with detachment and antithetic normal faulting events. The 'mound-scale' catalog contains microearthquakes local to the TAG active mound and intrinsic to hydrothermal processes. We test for coherent frequencies between the catalogs and each temperature record and find coherent frequencies $\left(C^{2}>0.5\right)$ between the mound-scale microearthquake catalog and seven of ten temperature probes. The microearthquake catalogs are not perfectly Poissonian point processes (i.e. coefficents of variation $>1$ ), so we use a Rotation Test, which preserves the internal temporal structure of the microearthquake catalogs, to test whether mean exit fluid venting temperatures are significantly higher following microearthquake events. We find that 2 out of 20 temperature probe-channels show significantly higher mean temperatures (95\% level of significance) following mound-scale microearthquakes, but results are different on two channels of the same probes and therefore cannot conclusively show feedbacks between subsurface seismicity and venting at those sites. Results of initial tests suggest that more refined methods may be necessary to define spatial and temporal relationships between subsurface cracking and hydraulic pathways to surface vents.
\end{abstract}




\section{Introduction}

Studies at deep-sea hydrothermal vents and geothermal sites on land have shown that seismic activity can affect hydrothermal flow by perturbing the thermal state and/or permeability structure of the local crust [Aki et al., 1982; Bame and Fehler, 1986; Ferrazzini et al., 1990; Sohn et al., 1998; Johnson et al., 2000; Bianco et al., 2004; Davis et al., 2004; Foulger et al., 2004; Wilcock, 2004; Cuenot et al., 2006]. While these observations provide intriguing evidence for seismic perturbation of hydrothermal flow, the extent to which they may be generalized is not clear. We do not yet understand how earthquake characteristics (e.g., size, location, source mechanism) contribute to hydrothermal perturbations, nor do we understand the role of local hydrogeology in the perturbation process(es). One way to assess these issues is with rigorous statistical analyses of hydrothermal flow records and contemporaneous earthquake catalogs to examine relationships in a universal framework.

Long-term flow records for deep-sea hydrothermal vents are relatively scarce owing to the logistical difficulties and expense associated with making these measurements. In the past decade, however, several observatory-style experiments providing concurrent measurements of local seismicity and hydrothermal exit-fluid temperatures have been conducted [Sohn et al., 1998; deMartin et al., 2007; Sohn, 2007a,b; Van Ark et al., 2007], and these data provide an excellent opportunity to assess the statistical correlation between flow records and earthquake catalogs. Here we focus on data acquired from the TAG active mound on the Mid-Atlantic Ridge (MAR, $26^{\circ} \mathrm{N}$ ) during the Seismicity and Fluid Flow of the TAG Hydrothermal Mound (STAG) experiment from 2003-2004. The experiment consisted of concurrent deployments of thirteen ocean bottom seismometers (OBSs), a seafloor pressure gauge, eight high-temperature probes, and twelve lowtemperature probes. Data acquired included concurrent catalogs of microearthquake data on both the scale of the segment and the scale of the hydrothermal mound, a year-long 
record of seafloor pressure, and year-long records of exit fluid temperatures at lowtemperature and high-temperature venting orifices on the surface of the TAG mound.

\section{Hydrothermal Flow Records from the TAG Active Mound}

The TAG active mound is a $\sim 200 \mathrm{~m}$ diameter, $\sim 50 \mathrm{~m}$ tall massive sulfide deposit that discharges hydrothermal fluids in excess of $360^{\circ} \mathrm{C}$ from a Black Smoker Complex (B.S.C.) of chimneys at the top of the mound, and diffuse, lower temperature $\left(<100^{\circ} \mathrm{C}\right)$ fluids from numerous discrete orifices/cracks on the mound's upper terrace [Campbell et al., 1988; Humphris et al., 1995; Tivey et al., 1995; Becker et al., 1996]. On the basis of geochronological studies, high temperature venting at the TAG active mound is thought to have begun roughly 20,000 - 50,000 years ago [Lalou et al., 1990, 1993, 1998]. The geochronological data indicate that the mound has experienced discrete pulses of activity every 5,000-6,000 years, with quiescent periods in between. Cooling of the mound during quiescence leads to dissolution of anhydrite, mass wasting, and extensive reworking of the sulfides [Humphris et al., 1995]. The most recent pulse of activity is believed to have begun 990 years ago [Lalou et al., 1998; You and Bickle, 1998].

Exit fluid temperatures were measured every $8 \mathrm{~min}$ (on low-temperature probes) or 10 min (on high-temperature probes) from 17 sites distributed across the upper terrace of the mound from June 2003 to June 2004 [Sohn, 2007a]. High-temperature records were obtained using Deep Sea Power and Light SeaLogger probes deployed in fractures discharging $\sim 360^{\circ} \mathrm{C}$ black smoker fluids, and low-temperature records were obtained using VEMCO Ltd. Minilog probes deployed in cracks discharging $\sim 20^{\circ} \mathrm{C}$ diffuse flow fluids. All (7) of the high-temperature records are clipped (low, $<150^{\circ} \mathrm{C}$ ) for extended periods of time during the experiment, and are therefore unsuitable for correlative analyses with earthquake catalogs. The ten low-temperature records, however, provide continuous data for the 12-month observation period (Figure 1) with only brief periods of clipping (high, $>60^{\circ} \mathrm{C}$ ) on a few of the probes (L1, L2, L4, and L7) (Figure 2). Each lowtemperature probe was equipped with two sensors placed a few $\mathrm{cm}$ apart yielding two 
separate records for each station, thereby providing redundancy in case of sensor failure and the capability to measure fine-scale spatial discharge variations. In our analyses, we treat each probe channel as a separate record, such that we have $2 \times 10=20$ individual temperature records to test against the earthquake catalogs.

The diffuse flow records exhibit a complex mix of episodic and harmonic variability with little apparent temporal correlation between records from different sites [Sohn, 2007a,b]. The temperature records form highly skewed, long-tailed, and multi-peaked empirical distributions that have been modeled as mixtures of Gamma densities [Sohn, 2007b]. Individual temperature records exhibit strong serial correlations, with the records commonly alternating between background bottom water temperatures indicative of noflow or possibly recharge and higher temperatures indicative of discharge. These characteristics led Sohn [2007b] to model the records as Hidden Markov Processes with three to five flow states, and to hypothesize that the processes triggering flow perturbations occur at very shallow depths within the mound.

\section{Microearthquake Catalogs}

In June 2003, a network of 13 ocean bottom seismometers (OBSs) was deployed on the TAG segment of the MAR (Figure 3) as part of the STAG Experiment. The OBSs recorded continuous data at $100 \mathrm{~Hz}$ on 4 channels (3 component, $4.5 \mathrm{~Hz}$ natural frequency geophone + hydrophone) from June, 2003 to February, 2004, corresponding to the first $\sim 9$ months of the exit-fluid temperature records. The network consisted of three rings of instruments centered on the active TAG mound: a $7 \times 7 \mathrm{~km}$ array of four OBSs and a 2 x 2 km array of four OBSs ('segment-scale' network), and a $200 \mathrm{~m}$ diameter array of five OBSs deployed on the periphery of the TAG active mound ('mound-scale' subnetwork) (Figure 2).

Two microearthquake catalogs have been derived from the OBS data. deMartin et al. [2007] generated a catalog of 19,232 regional microearthquakes that were recorded by all 
of the OBSs in the network (Figure 3B). These events, with local magnitudes ranging from $1 \leq M_{L} \leq 4$, represent tectonic extension on the active detachment fault and the deforming fault footwall. More recently, Pontbriand and Sohn [submitted] generated a catalog of 32,078 microearthquakes that were only recorded by the mound-scale subnetwork. These events, with local magnitudes of -1.4 $\leq M_{L} \leq 0.5$, cluster along two linear trends that intersect near the southwest corner of the active mound (Figure 3C), and are believed to represent cracking generated by anhydrite deposition in the secondary circulation system. The two catalogs are complementary in that the regional events are associated with segment-scale tectonic extension whereas the local events are associated with mound-scale fluid flow and mineral deposition.

Both microearthquake catalogs exhibit relatively steady seismicity rates with no apparent mainshock-aftershock behavior. The segment-scale catalog has a rate of $\sim 88$ events/day, corresponding to a mean inter-event time of $17.5 \mathrm{~min}$, whereas the mound-scale catalog has a rate of $\sim 243$ events/day (until the detection threshold increases as a result of instrument failure), corresponding to a mean inter-event time of $10.3 \mathrm{~min}$ (Figure 4). The tendency for earthquakes to cluster in time is described by the coefficient of variation $\left(C_{v}\right)$ [Kagan and Jackson, 1991], which is the standard deviation of inter-event times divided by the mean inter-event time. If the temporal behavior is completely random (i.e., Poisson process) the coefficient of variation takes a value of one. If the events cluster in time the coefficient of variation will be greater than one, while by contrast if the events occur periodically, the coefficient of variation approaches zero. Coefficients of variation for the segment-scale and mound-scale catalogs are 2.42 and 1.25, respectively, indicating that both catalogs exhibit statistically significant clustering in time. The interevent times of mound-scale events are much shorter, as we would expect from magnitude-rate models [e.g. Ogata, 1988], with maximum inter-event times an order of magnitude shorter than those of the segment-scale catalog ( $\sim 4$ hours vs $\sim 40$ hours). Interevent times from neither catalog fit an exponential distribution, providing additional evidence that they cannot be modeled as a Poisson process. 
Loading from ocean and earth tides has been hypothesized to trigger microearthquake activity at mid-ocean ridge hydrothermal fields [Tolstoy et al., 2002; Crone and Wilcock, 2005]. Both the segment-scale and mound-scale catalogs in this study have coefficients of variation greater than one, arguing against perfectly periodic behavior as would be expected from tidal triggering, but we use spectral methods to explicitly investigate periodic behavior at tidal frequencies. We estimate the power spectral density of the catalogs using the method of Brillinger [1974] wherein the point process is converted to a continuous process by counting the number of events in discrete time windows. Each catalog is binned on the sampling time scale of the pressure gauge data (i.e. 10 min bins). Power spectra for the mound-scale microearthquake catalog (Figure 5A) does not exhibit peaks at any of the tidal frequencies, indicating that tidal loading does not play a significant role in triggering microearthquakes associated with mound-scale fluid flow. This result is reinforced by the lack of coherency between the catalog with concurrently measured ocean tide data (bottom pressure) and predicted solid earth tides (Figure 5E, Figure 5F). Power spectra for the segment-scale microearthquake catalog (Figure 5B) exhibits a peaks at the $\mathrm{M}_{2}$ tidal constituent, indicating that tidal loading at the principal lunar semi-diurnal tidal periodicity may play a role in triggering microearthquakes associated with segment-scale deformation. This result is reinforced by the coherency between the catalog with the predicted solid earth tide (Figure $5 \mathrm{H}$ ), but is not present in the comparison between the segment-scale catalog and pressure gauge data (Figure 5E). Coherence at $\mathrm{M}_{2}$ is robust to higher levels of spectral smoothing.

\section{Statistical Tests and Initial Results}

We use spectral statistical methods and a non-parametric rotation test to compare segment-scale and mound-scale microearthquakes with exit-fluid temperature records to assess potential feedbacks between microearthquakes and fluid flow. Here we focus on temporal correlations, though spatiotemporal models may be possible in the future. Data from each temperature probe channel are treated individually against the microearthquake 
catalogs, such that each observation site is tested twice (once for each channel). In order to have 'significant' correlation at a given site we require significant correlations for both channels on an exit fluid temperature probe.

\subsection{Spectral coherence: Microearthquakes vs. exit fluid temperatures}

We use a multi-taper spectral method to compare the spectral content of the microearthquake catalogs and exit fluid temperature records. Results shown are robust for both $\mathrm{NW}=3$ and NW=5 levels of spectral smoothing, and coherences reported are consistently high over frequency bands as opposed to at single frequencies. Earthquake data are binned at the sample interval of the exit fluid records (8 minutes). Periods with coherences greater than 0.5 (and significantly greater than zero, $C^{2}>0$, with $95 \%$ confidence [Percival and Walden, 1993]) are found in Table 1 for the mound-scale catalog. 
Table 1. A comparison of the mound-scale microearthquake catalog to each exit fluid temperature probe shows that some coherent periods $\left(C^{2}>0.5\right)$ exist on both probe channels. Coherences reported are a result of multitaper spectral analysis with $\mathrm{NW}=3$, but results presented are robust at both $\mathrm{NW}=3$ and $\mathrm{NW}=5$ levels of smoothing.

\begin{tabular}{cccc}
\hline $\begin{array}{c}\text { Probe (vs. mound-scale } \\
\text { catalog) }\end{array}$ & Period & $\begin{array}{c}\text { Coherence with } \\
\text { Channel 1 record }\end{array}$ & $\begin{array}{c}\text { Coherence with } \\
\text { Channel 2 record }\end{array}$ \\
\hline L1 & 19.1 min & 0.67 & 0.65 \\
L4 & 3.1 hours & 0.71 & 0.78 \\
& 1.1 hours & 0.74 & 0.66 \\
& 20.8 min & 0.69 & 0.73 \\
\hline L5 & 1.2 days & 0.50 & 0.92 \\
\hline L8 & 23.7 min & 0.61 & 0.55 \\
\hline L9 & 55.2 min & 0.62 & 0.75 \\
\hline L11 & 1.8 hours & 0.76 & 0.77 \\
& 38.9 min & 0.57 & 0.56 \\
& 21.3 min & 0.51 & 0.51 \\
\hline L12 & 1.5 hours & 0.81 & 0.72 \\
& 23.5 min & 0.81 & 0.67 \\
& 17.54 min & 0.62 & 0.58 \\
\hline
\end{tabular}

Exit fluid probes that show consistent coherent periods with the mound-scale microearthquake catalog on both channels are L1 (Figure 6), L4 (Figure 7), L5 (Figure 8), L8 (Figure 9), L9 (Figure 10), L11 (Figure 11), and L12 (Figure 12). Interpretation of periodicities is difficult, though coherent periods in the range of 19-24 min are seen on L1, L4, L8, L11, and L12. Only L5 shows a coherent period on the length scale of a day, at 1.2 days, which is slightly longer than the period of $\mathrm{O}_{1}$, the lunar diurnal tidal constituent.

A comparison of the segment-scale microearthquake catalog to each exit fluid temperature probe finds that no coherent periods $\left(C^{2}>0.5\right)$ exist on both probe 
channels. However one probe, L11, shows a small level of coherence $\left(C^{2}=0.4\right)$ with the segment-scale catalog at a period 12.4 hours, the lunar semidiurnal tidal period. This is in agreement with the observation of coherency between the segment-scale catalog and the predicted solid earth tide at $\mathrm{M}_{2}$. The exit fluid temperature record on probe L11 has been shown to have a strong spectral peak at $\mathrm{M}_{2}$ [Sohn, 2007a].

\subsection{Nonparametric rotation test for behavioral point process data}

Suppose that microearthquake events are observed over a period $(0, T)$ where in this case $T$ is 9 months from the start of the experiment. We have discussed how the microearthquake catalogs contain clustering, so assumptions of Poissonian point processes are not valid when correlating the catalogs to exit fluid temperature records. In order to make this comparison, we use a rotation test that preserves the interevent times of the microearthquake events, but "randomizes" the start time of the entire catalog with respect to the exit fluid temperature catalog. In this test microearthquake events are treated as having no duration. This approximation is reasonable because the duration of events $(\sim 1 \mathrm{sec})$ is small in relation to the interval over which we are looking for effects in temperature (8 -64 minutes). A point of consideration is whether randomly selected time windows will contain an earthquake and thus be un-representative of "non-event" exit fluid temperatures. If this consideration is factual, we would expect to always accept the null hypothesis that there is no significant difference in exit fluid temperatures following microearthquakes and a randomly generated distribution of mean exit fluid temperatures. However, we find that this is not the case so time windows up to 64 minutes appear appropriate for gauging the responsiveness of venting temperatures to microearthquakes. The procedure of this test is to randomly "rotate" times of microearthquakes to form a distribution of mean temperatures, thereby preserving the internal structure of the microearthquake catalog [Deruiter and Solow, 2008].

First we determine the optimal time window following an earthquake event over which exit fluid temperature is maximized. We do so by finding the length of the time window 
that maximizes the average exit fluid temperature following all the microearthquake events in the catalog. Then we randomly rotate the times of the microearthquake events, determine the optimal time delay, and calculate the mean temperature at these times [c.f. Deruiter and Solow, 2008]. We repeat this procedure 1000 times to approximate the distribution of mean exit fluid temperature. Finally, we test whether the mean exit fluid temperature following earthquake events is significantly higher than that of the bootstrapped distribution using a non-parametric rank test. This test is repeated for each exit fluid temperature probe record.

\section{Test hypotheses:}

$\mathrm{H}_{0}$ : Mean exit fluid temperature following earthquake events is not statistically different from background temperature fluctuations.

$\mathrm{H}_{1}$ : Mean exit fluid temperature is significantly higher following microearthquake events.

\section{Test statistic:}

Nonparametric rank test statistic at 95\% confidence level (one-sided test).

If mean exit fluid temperature following earthquakes is greater than the test statistic, we reject $\mathrm{H}_{0}$. 
Table 3. Results of rotation test between the mound-scale microearthquake catalog and exit fluid temperature records. If we reject the null hypothesis, then mean exit fluid temperature is significantly higher following mound-scale microearthquake events. If we do not reject the null hypothesis, then mean exit fluid temperatures are not significantly higher following mound-scale microearthquakes.

\begin{tabular}{|c|c|c|c|c|c|c|}
\hline $\begin{array}{l}\text { Temp. } \\
\text { Probe }\end{array}$ & $\begin{array}{l}\text { Optimal } \\
\text { time } \\
\text { window } \\
(\min )\end{array}$ & $\begin{array}{l}\text { Mean temp. } \\
\text { following } \\
\text { earthquakes } \\
\left({ }^{\circ} \mathrm{C}\right)\end{array}$ & $\begin{array}{l}\text { Confidence } \\
\text { level }\end{array}$ & $\begin{array}{l}\text { Bootstrap } \\
\text { samples }\end{array}$ & $\begin{array}{l}\text { Critical } \\
\text { value }\left({ }^{\circ} \mathrm{C}\right)\end{array}$ & Conclusion \\
\hline L1-Chan1 & 48 & 3.718 & $95 \%$ & 607 & 3.720 & Do not reject $\mathrm{H}_{\mathrm{C}}$ \\
\hline L1-Chan2 & 8 & 3.970 & “" & 800 & 3.974 & Do not reject $\mathrm{H}_{\mathrm{C}}$ \\
\hline L2-Chan1 & 64 & 8.864 & “ & 129 & 8.929 & Do not reject $\mathrm{H}_{0}$ \\
\hline L2-Chan2 & 56 & 14.613 & “" & 1000 & 14.550 & Reject $\mathrm{H}_{0}$ \\
\hline L4-Chan1 & 8 & 14.488 & "“ & 413 & 14.522 & Do not reject $\mathrm{H}_{\mathrm{C}}$ \\
\hline L4-Chan2 & 8 & 7.563 & “" & 1000 & 7.512 & Reject $\mathrm{H}_{0}$ \\
\hline L5-Chan1 & 64 & 5.079 & “" & 202 & 5.089 & Do not reject $\mathrm{H}_{0}$ \\
\hline L5-Chan2 & 8 & 5.929 & “" & 67 & 5.935 & Do not reject $\mathrm{H}_{0}$ \\
\hline L6-Chan1 & 32 & 4.974 & “" & 134 & 4.975 & Do not reject $\mathrm{H}_{0}$ \\
\hline L6-Chan2 & 64 & 6.556 & “" & 73 & 6.558 & Do not reject $\mathrm{H}_{0}$ \\
\hline L7-Chan1 & 64 & 34.799 & “" & 99 & 34.821 & Do not reject $\mathrm{H}_{0}$ \\
\hline L7-Chan2 & 8 & 40.022 & “" & 178 & 40.054 & Do not reject $\mathrm{H}_{0}$ \\
\hline L8-Chan1 & 16 & 16.367 & “" & 54 & 16.371 & Do not reject $\mathrm{H}_{0}$ \\
\hline L8-Chan2 & 24 & 12.890 & “ & 70 & 13.121 & Do not reject $\mathrm{H}_{0}$ \\
\hline L9-Chan1 & 40 & 4.416 & “" & 116 & 4.417 & Do not reject $\mathrm{H}_{0}$ \\
\hline L9-Chan2 & 48 & 4.394 & “" & 142 & 4.450 & Do not reject $\mathrm{H}_{c}$ \\
\hline $\begin{array}{l}\text { L11- } \\
\text { Chan1 }\end{array}$ & 64 & 6.870 & “ & 53 & 6.909 & Do not reject $\mathrm{H}_{0}$ \\
\hline $\begin{array}{l}\text { L11- } \\
\text { Chan2 }\end{array}$ & 64 & 6.812 & “" & 215 & 3.477 & Do not reject $\mathrm{H}_{0}$ \\
\hline $\begin{array}{l}\text { L12- } \\
\text { Chan1 }\end{array}$ & 48 & 3.460 & "“ & 441 & 3.618 & Do not reject $\mathrm{H}_{0}$ \\
\hline $\begin{array}{l}\text { L12- } \\
\text { Chan2 }\end{array}$ & 48 & 3.418 & “ & 210 & 3.421 & Do not reject $\mathrm{H}_{0}$ \\
\hline
\end{tabular}


When accounting for inter-event time structure of the mound-scale microearthquake catalog, only tests on L2-Channel 2 and L4-Channel 2 (Figure 13) find significantly higher mean exit fluid temperatures following mound-scale microearthquake events. We do not see similar behavior on both channels of these two probes.

There is also a possible model in which microearthquakes increase permeability and amounts of entrained seawater, thereby lowering exit fluid temperatures. The rotation test method is repeated to look for evidence of significantly lower temperatures following microearthquakes. Results (Table 4) show no evidence of lower temperatures on any of the exit temperature probes following local microearthquakes. 
Table 4. Results of rotation test $\# 2$ between the mound-scale microearthquake catalog and exit fluid temperature records. If we reject the null hypothesis, then mean exit fluid temperature is significantly lower following mound-scale microearthquake events. If we do not reject the null hypothesis, then mean exit fluid temperatures are not significantly lower following mound-scale microearthquakes.

\begin{tabular}{|c|c|c|c|c|c|}
\hline Temp. Probe & $\begin{array}{l}\text { Optimal } \\
\text { time } \\
\text { window } \\
\text { (min) }\end{array}$ & $\begin{array}{l}\text { Mean temp. } \\
\text { following } \\
\text { earthquakes } \\
\left({ }^{\circ} \mathrm{C}\right)\end{array}$ & $\begin{array}{l}\text { Confidence } \\
\text { level }\end{array}$ & $\begin{array}{l}\text { Critical } \\
\text { value }\left({ }^{\circ} \mathrm{C}\right)\end{array}$ & Conclusion \\
\hline L1-Chan1 & 16 & 3.715 & $95 \%$ & 3.309 & Do not reject $\mathrm{H}_{0}$ \\
\hline L1-Chan2 & 64 & 3.965 & “ & 3.536 & Do not reject $\mathrm{H}_{0}$ \\
\hline L2-Chan1 & 16 & 8.860 & “ & 8.350 & Do not reject $\mathrm{H}_{0}$ \\
\hline L2-Chan2 & 40 & 14.606 & " & 9.305 & Do not reject $\mathrm{H}_{0}$ \\
\hline L4-Chan1 & 64 & 14.477 & “" & 7.608 & Do not reject $\mathrm{H}_{0}$ \\
\hline L4-Chan2 & 64 & 7.558 & “ & 4.438 & Do not reject $\mathrm{H}_{0}$ \\
\hline L5-Chan1 & 24 & 5.075 & “" & 4.830 & Do not reject $\mathrm{H}_{0}$ \\
\hline L5-Chan2 & 40 & 5.923 & “ & 5.922 & Do not reject $\mathrm{H}_{0}$ \\
\hline L6-Chan1 & 8 & 4.971 & “" & 4.762 & Do not reject $\mathrm{H}_{0}$ \\
\hline L6-Chan2 & 8 & 6.551 & “" & 6.551 & Do not reject $\mathrm{H}_{0}$ \\
\hline L7-Chan 1 & 8 & 34.776 & " & 34.142 & Do not reject $\mathrm{H}_{0}$ \\
\hline L7-Chan2 & 32 & 40.007 & “ & 37.366 & Do not reject $\mathrm{H}_{0}$ \\
\hline L8-Chan 1 & 8 & 16.364 & " & 16.363 & Do not reject $\mathrm{H}_{0}$ \\
\hline L8-Chan2 & 8 & 12.885 & “ & 12.879 & Do not reject $\mathrm{H}_{0}$ \\
\hline L9-Chan 1 & 8 & 4.415 & " & 4.192 & Do not reject $\mathrm{H}_{0}$ \\
\hline L9-Chan2 & 16 & 4.391 & “ & 4.115 & Do not reject $\mathrm{H}_{0}$ \\
\hline L11-Chan1 & 24 & 6.862 & “ & 6.851 & Do not reject $\mathrm{H}_{0}$ \\
\hline L11-Chan2 & 24 & 6.804 & “ & 6.803 & Do not reject $\mathrm{H}_{0}$ \\
\hline L12-Chan1 & 16 & 3.458 & “ & 3.064 & Do not reject $\mathrm{H}_{0}$ \\
\hline L12-Chan2 & 8 & 3.416 & " & 3.054 & Do not reject $\mathrm{H}_{0}$ \\
\hline
\end{tabular}


In a similar comparison of the segment-scale microearthquake catalog to each exit fluid temperature probe, each rotation test concluded that accept the null hypothesis. In other words, no exit fluid temperature probes appeared to record significantly higher temperatures following segment-scale earthquakes.

\section{Discussion}

Given the results of spectral analysis and coherence measurements between the moundscale microearthquake catalog and exit fluid temperature records, we suggest that exit fluid temperatures may experience some feedbacks from microearthquakes, which we suggest are caused by the opening of fluid flow pathways in response to reaction-driven cracking of veins of anhydrite deposition. Interpretation of coherent periodicities is difficult, though coherent periods in the range of 19-24 min are seen on both channels of five temperature probes (L1, L4, L8, L11, and L12). Similarly short periods of $22 \mathrm{~min}$, $26.5 \mathrm{~min}, 33.4 \mathrm{~min}, 37.7 \mathrm{~min}, 53.2 \mathrm{~min}$, and $90 \mathrm{~min}$ are evident in pressure gauge data recorded near the TAG active mound. Periods in pressure gauge data are interpreted to represent vertical motion of the seafloor in response to hydrothermal flow - similar to ground surface deformation at terrestrial geysers [c.f. Sohn et al., 2009]. Perhaps a related process, such as a pressure cycle associated with flux of fluid or heat into the subsurface

of the hydrothermal mound, may influence the mound-scale microearthquakes, exit fluid temperatures, and pressure gauge data, but much more detailed analysis is required to better understand correlations in the dataset. Although two probe-channels at different sites find significantly higher mean exit fluid temperatures following mound-scale microearthquakes, the rotation tests fail to find any sites where both probe channels test 'positive' against the catalog, suggesting that the mound-scale catalog as a whole did not have a measurable impact on the discharge temperatures that we measured. Considering the complex hydraulic structure and wide spatial distribution of mound-scale microearthquakes with respect to the temperature probes, finding a response in temperature on only two probes for the rotation test is a significant discovery of signal in the noise. More refined comparisons of the spatiotemporal behavior of exit fluid 
temperatures and shallow mound-scale microearthquakes is warranted (e.g. comparison to state changes in HMMs).

Tidal signals are apparent in the variability of exit fluid temperatures and in the segmentscale microearthquake catalog $\left(\right.$ as $\left.\mathrm{M}_{2}\right)$. The mound-scale microearthquake catalogs lack coherence with major tidal constituents, however. Thus tidal loading appears to contribute to regional fault failure on a lunar semidiurnal period, but does not affect the timing of dilatant fracture opening. No other notable correlations are found between the segment-scale microearthquakes and exit fluid venting temperatures at the TAG active mound. 


\section{References}

Becker, K., R. Von Herzen, J. Kirklin, R. Evans, D. Kadko, M. Kinoshita, O. Matsubayashi, R. Mills, A. Schultz, and P. Rona (1996), Conductive heat flow at the TAG active hydrothermal mound: Results from 1993-1995 submersible surveys, Geophys. Res. Lett., 23, 3463-3466.

Bohnentiehl, D.R., and M. C. Kleinrock (2000), Fissuring near the TAG active hydrothermal mound, $26^{\circ} \mathrm{N}$ on the Mid-Atlantic Ridge, J. of Volcanol. and Geotherm. Res., 98, 33-48.

Brillinger, D. R., Statistical inference for stationary point processes, Proceedings of the Summer Research Institute on Statistical Inference for Stochastic Processes, Bloomington, Indiana, July 31- August 9, 1974, Vol 1, p. 55-99.

Campbell, A. C., M. R. Palmer, G. P. Klinkhammer, T. S. Bowers, J. M. Edmond, J. R. Lawrence, J. F. Casey, G. Thompson, S. Humphris, P. Rona, and J. A. Karson (1988), Chemistry of hot springs on the Mid-Atlantic Ridge, Nature, 335(6), 514519.

Chevaldonné, P., D. Desbruyères, and M. Le Haître, 1991, Time-series of temperature from three deep-sea hydrothermal vent sites. Deep Sea Res. 38(11): 1417-1430.

Chiba, H., N. Uchiyama, and D. A. H. Teagle (1998), Stable isotope study of an- hydrite and sulfide minerals at the TAG hydrothermal mound, Mid-Atlantic Ridge, $26^{\circ} \mathrm{N}$, in Proceedings of the Ocean Drilling Program, Scientific Results, vol. 158, edited by P. M. Herzig, S. E. Humphris, et al., pp. 85-90, College Station, Texas, Ocean Drilling Program.

Corral, A. (2004), Long-term clustering, scaling, and universality in the temporal occurrence of earthquakes, Physical Review Letters, 92(10), doi:10.1103/PhysRevLett.92.108501.

Crone, T. J., and W. S. D. Wilcock (2005), Modeling the effects of tidal loading on midocean ridge hydrothermal systems, Geochem. Geophys. Geosys., 6(7), doi:10.1029/2004GC000905.

Davis, E., K. Becker, R. Dziak, J. Cassidy, K. Wang, and M. Lilley (2004), Hydrological response to a seafloor spreading episode on the Juan de Fuca ridge, Nature, 430, 335-338.

deMartin, B. J., R. A. Sohn, J. P. Canales, and S. E. Humphris (2007), Kinematics and geometry of active detachment faulting beneath the Trans-Atlantic Geotraverse (TAG) hydrothermal field on the Mid-Atlantic Ridge, Geology, 35, 711-714. 
Deruiter, S. L. and A. R. Solow, 2008, A rotation test for behavioural point-process data. Animal behavior, 76, 1429-1434.

Edmond, J. M., A. C. Campbell, M. R. Palmer, G. P. Klinkhammer, C. R. German, H. N. Edmonds, H. Elderfield, G. Thompson, and P. A. Rona (1995), Time series studies of vent fluids from the TAG and MARK sites $(1986,1990)$ Mid-Atlantic Ridge: A new solution chemistry model and mechanism for $\mathrm{Cu} / \mathrm{Zn}$ zonation in massive sulfide orebodies, in Hydrothermal vents and processes, Geological Society of London Special Publication, vol. 87, edited by L. M. Parson, C. L. Walker, and D. R. Dixon, pp. 77-86.

Goto, S., M. Kinoshita, A. Schultz, and R. P. Von Herzen, 2003, Estimate of heat flux and its temporal variation at the TAG hydrothermal mound, Mid-Atlantic Ridge 26N, J. Geophys. Res. 108(B9),doi:10.1029/2001JB000703.

Honnorez, J. J., J. C. Alt, and S. E. Humphris (1998), Vivisection and autopsy of active and fossil hydrothermal alterations of basalt beneath and within the TAG hydrothermal mound, in Proceedings of the Ocean Drilling Program, Scientific Results, vol. 158, edited by P. M. Herzig, S. E. Humphris, et al., pp. 231-254, College Station, Texas, Ocean Drilling Program.

Humphris, S. E., P. M. Herzig, D. J. Miller, et al. (1995), The internal structure of an active sea-floor massive sulphide deposit, Nature, 377, 713-716.

Humphris, S. E., and M. C. Kleinrock (1996), Detailed morphology of the TAG active hydrothermal mound: Insights into its formation and growth, Geophys. Res. Lett., $23,3443-3446$.

Humphris, S., P. Herzig, J. Miller, J. Alt, K. Becker, D. Brown, et al. (1996), TAG-1 Area, in Proceedings of the Ocean Drilling Project, Initial Reports, vol. 158, edited by S. E. Humphris, P. Herzig, D. Miller, et al., pp. 65-140, College Station, TX: Ocean Drilling Program.

Humphris, S.E., and J. R. Cann (2000), Constraints on the energy and chemical balances of the modern TAG and ancient Cyprus seafloor sulfide deposits, J. Geophys. Res., 105, 28477-28488.

Humphris, S. E., and W. Bach (2005), On the Sr isotope and REE compositions of anhydrites form the TAG seafloor hydrothermal system, Geochimica et Cosmochimica Acta, 69(6), 1511-1525, doi:10.1016/j.gca.2004.10.004. 
James, R. H., and H. Elderfield (1996), The chemistry of ore-forming fluids and mineral precipitation rates in an active hydrothermal sulphide deposit on the Mid-Atlantic Ridge, Geology, 24, 1147-1150.

Johnson, H. P., M. Hutnak, R. P. Dziak, C. G. Fox, I. Urcuyo, J. P. Cowen, J. Nabelek, C. Fisher (2000), Earthquake-induced changes in a hydrothermal system on the Juan de Fuca mid-ocean ridge, Nature, 407, 174-177.

Jupp, T. E. and A. Schultz, 2004, A poroelastic model for the tidal modulation of seafloor hydrothermal systems. J. Geophys. Res. 109(B03104), doi: 10.1029/2003JB002583.

Kagan, Y. Y., and D. D. Jackson (1991), Long-term earthquake clustering, Geophys. J. Int., 104, 117-113.

Kinoshita, M., O. Matsubayashi, R. P. Von Herzen, 1996, Sub-bottom temperature anomalies detected by long-term temperature monitoring at the TAG hydrothermal mound, Geophys. Res. Letters, 23(23):3467-3470.

Kleinrock, M. C., and S. E. Humphris (1996), Structural control on seafloor hydrothermal activity at the TAG active mound, Nature, 382, 149-153.

Lalou, C., G. Thompson, M. Arnold, E. Brichet, E. Druffel, and P. A. Rona (1990), Geochronology of TAG and Snake Pit hydrothermal fields, Mid- Atlantic Ridge: Witness to a long and complex hydrothermal history, Earth Planetary Science Letters, 97, 113-128.

Lalou, C., J. L. Reyss, E. Brichet, M. Arnold, G. Thompson, Y. Fouquet, and P. A. Rona (1993), New age data for Mid-Atlantic Ridge hydrothermal sites: TAG and Snakepit geochronology revisited, J. Geophys. Res., 98, 9705-9713.

Lalou, C., J. L. Reyss, and E. Brichet (1998), Age of sub-bottom sulfide samples at the TAG active mound, in Proceedings of the Ocean Drilling Program, Scientific Results, vol. 158, edited by P. M. Herzig, S. E. Humphris, et al., pp. 111-117, College Station, Texas, Ocean Drilling Program.

Lowell, R. P., and Y. Yao (2002), Anhydrite precipitation and the extent of hydrothermal recharge zones at ocean ridge crests, J. Geophys. Res., 107(B9), 2182, doi: 10.1029/2001JB001289.

McGregor, B. A., and P. A. Rona (1975), Crest of Mid-Atlantic Ridge at $26^{\circ} \mathrm{N}, J$. Geophys. Res., 80, 3307-3314. 
McGregor, B. A., C. G. A. Harrison, J. W. Lavelle, and P. A. Rona (1977), Magnetic anomaly pattern on the Mid-Atlantic Ridge crest at $26^{\circ} \mathrm{N}, J$. Geophys. Res., 82, 231-238.

Ogata, Y. (1988), Statistical models for earthquake occurrences and residual analysis for point processes, J. Amer. Stat. Assoc., 83, 401, 9-27.

Ogata, Y., 1999, Seismicity analysis through point-process modeling: A review. Pure appl. Geophys. 155: 471-507.

Ogata, Y., K. Katsura, and J. Zhuang, 2006, TIMSAC84: Statistical analysis of series of events (TIMSAC84-SASE) Version 2, Computer Science Monographs, A publication of the Institute of Statistical Mathematics, No. 32.

Saichev, A., and D. Sornette (2007), Theory of earthquake reccurence times, J. Geophys. Res., 112(B04313), doi: 10.1029/2006JB004536.

Schultz, A., P. Dickson, and H. Elderfield, 1996, Temporal variations in diffuse hydrothermal flow at TAG, Geophys Res. Letters. 23(23):3471-3474.

Sohn, R., D. Fornari, K. Von Damm, J. Hildebrand, and S. Webb (1998), Seismic and hydrothermal evidence for a cracking event on the East Pacific Rise crest at 950’ N, Nature, 396, 159-161.

Sohn, R. A. (2007a), Stochastic analysis of exit fluid temperature records from the active TAG hydrothermal mound (Mid-Atlantic Ridge, $26^{\circ} \mathrm{N}$ ): 1 . Modes of variability and implications for subsurface flow, J. Geophys. Res., 112: B07101, doi:10.1029/2007JB004435.

Sohn, R. A. (2007b), Stochastic analysis of exit fluid temperature records from the active TAG hydrothermal mound (Mid-Atlantic Ridge, $26^{\circ} \mathrm{N}$ ): 2. Hidden Markov models of flow episodes, J. Geophys. Res., 112: B09102, doi:10.1029/2007JB004961.

Sohn, R. A., R. E. Thomson, A. B. Rabinovich, and S. F. Mihaly (2009), Bottom pressure signals at the TAG deep-sea hydrothermal field: Evidence for short-period, flowinduced ground deformation, Geophys. Res. Lett., 36, L19301, doi:10.1029/2009GL040006.

Teagle, D. A. H., J. C. Alt, H. Chiba, S. E. Humphris, A. N. Halliday (1998), Strontium and oxygen isotopic constraints on fluid mixing, alteration and mineralization in the TAG hydrothermal deposit, Chemical Geology, 149, 1-24. 
Tivey, M. K., S. E. Humphris, G. Thompson, M. D. Hannington, and P. A. Rona (1995), Deducing patterns of fluid flow and mixing within the active TAG mound using mineralogical and geochemical data, J. Geophys. Res., 100, 12527-12555.

Tivey, M. K., A. M. Bradley, T. M. Joyce, and D. Kadko, 2002, Insights into tide-related variability at seafloor hydrothermal vents from time-series temperature measurements. EPSL, 202: 693-707.

Utsu, T. and Y. Ogata (1997), Computer program package: Statistical analysis of point processes for seismicity, SASeis, IASPEI Software Library for personal computers, the International Association of Seismology and Physics of Earth's Interior in collaboration with the American Seismological Society, Vol. 6, pp. 1394.

Van Ark, E. M., R. S. Detrick, J. P. Canales, et al., (2007), Seismic structure of the Endeavour Segment, Juan de Fuca Ridge: Correlations with seismicity and hydrothermal activity, J. Geophys. Res., 112(B02401), doi: 10.1029/2005JB004210.

Wilcock, W. S. D., and D. R. Toomey (1991), Estimating hypocentral uncertainties for marine microearthquake surveys: A comparison of the generalized inverse and grid search methods, Marine Geophysical Researches, 13, 161-171.

You, C. F., and M. J. Bickle (1998), Evolution of an active sea-floor massive sulphide deposit, Nature, 394, 668-671. 
Figure 1. Low-temperature exit fluid temperature records displayed clockwise around the mound starting with probe L12 in the ODP 6 depression. Two records are shown for each probe (left). Time series data and (right) data histograms. The y-axis of the histograms represents normalized frequency, which is the number of observations in each data bin divided by the total number of observations (data are binned in digitization bins of the data loggers). Many of the records contained large fractions of measurements in the first few data bins corresponding to background water column temperature levels $\left(>2.7^{\circ} \mathrm{C}\right)$, and in such cases a small y axis interval of $0-0.1$ is retained to bring out the details of the histogram shape, but the fraction of observations in the background temperature bins is explicitly listed (e.g., the two probes at site L12 returned background temperature measurements $45 \%$ and $56 \%$ of the time, respectively.

\section{Time-series}
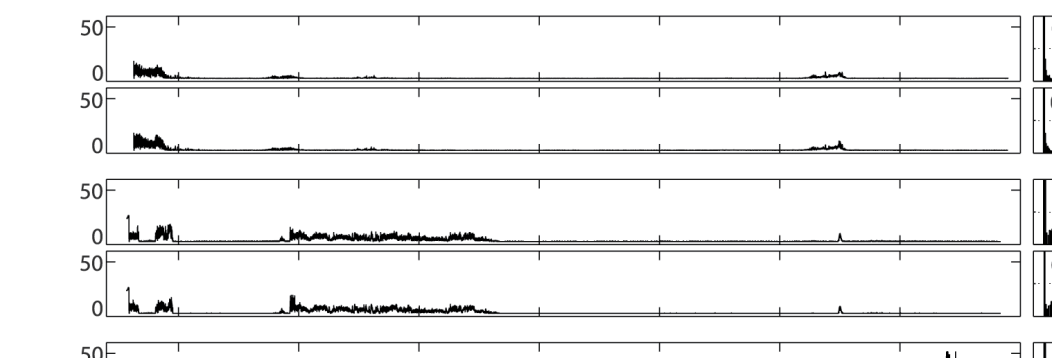

Histograms
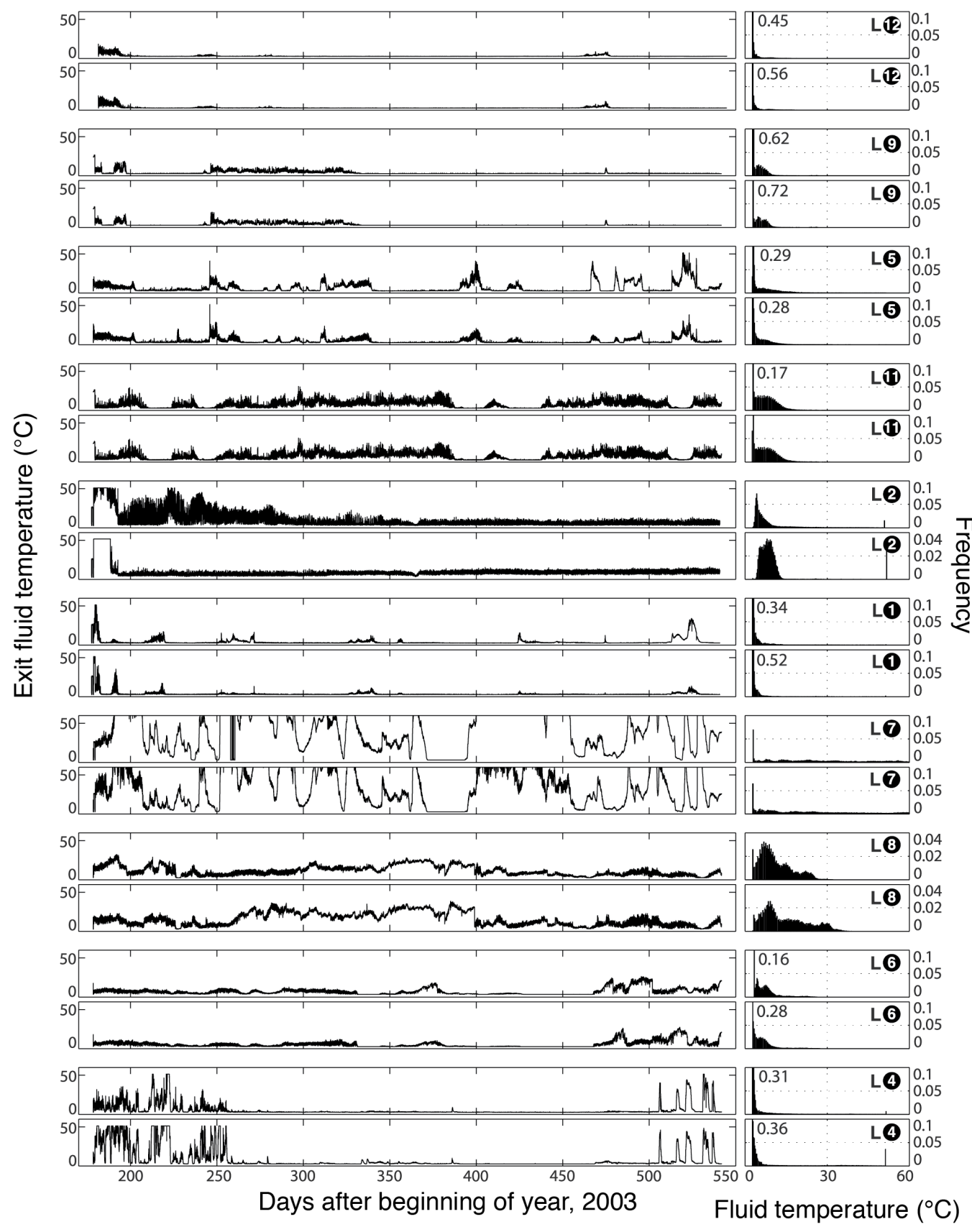
Figure 2. Bathymetry of the area surrounding the TAG active mound [Roman and Singh, 2007]. The active hydrothermal deposit (white dashed circle labeled MOUND) is the 200 $\mathrm{m}$ diameter feature with two terraces surrounded by 5 OBSs of the mound-scale network (triangles). STIR-12 (black triangle) failed 77 days into the experiment. The main chimney, or Black Smoker Complex (B.S.C.) sits atop the upper terrace within the small dashed white circle. Ten low temperature probes (black circles) are deployed on the upper terrace of the sulfide deposit.

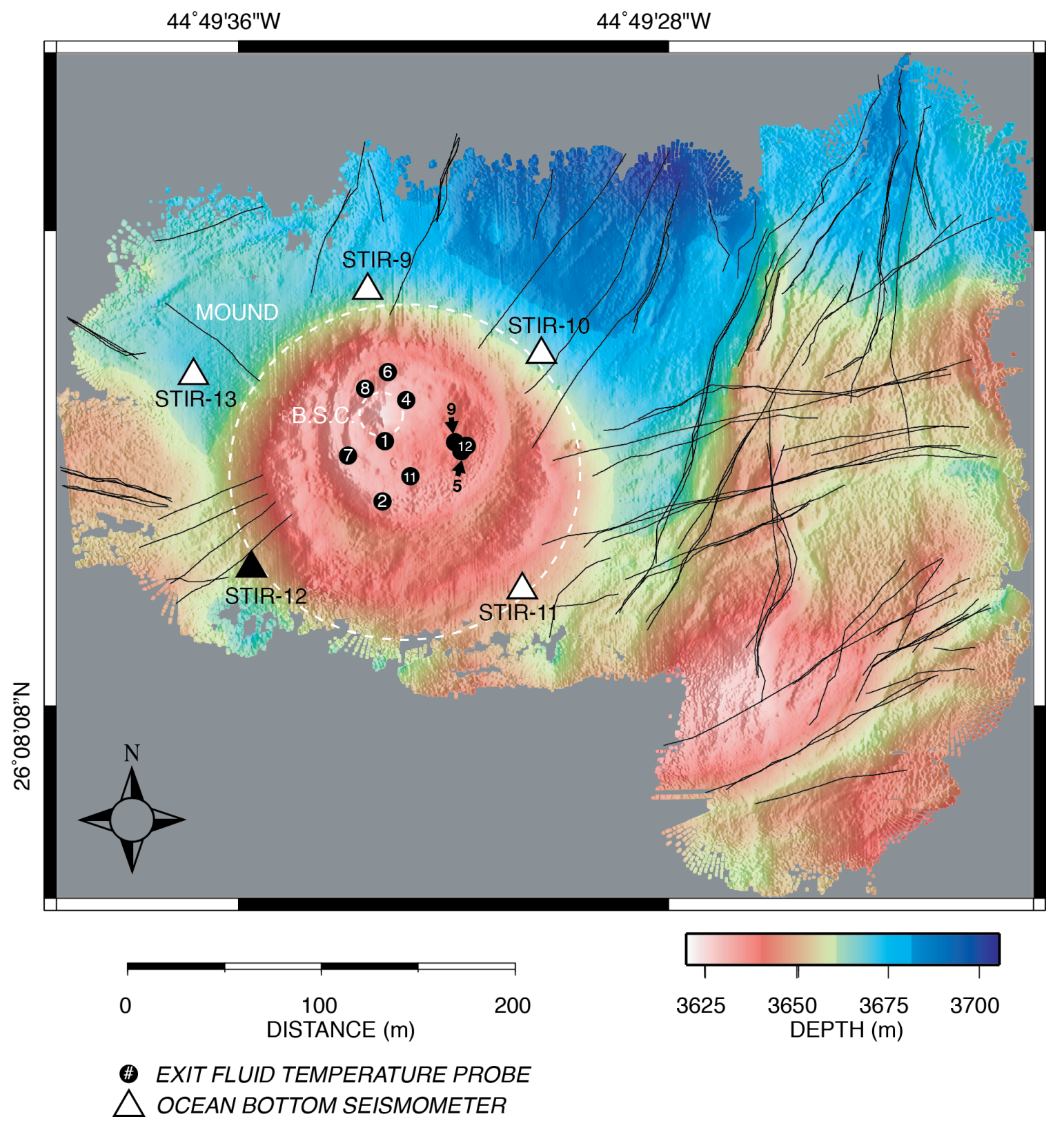


Figure 3. (A) Area map of the Mid-Atlantic Ridge at $26^{\circ} \mathrm{N}$ and the TAG hydrothermal field. (B) Bathymetry of the TAG segment with microearthquake epicenters (black dots) detected on the segment-scale network depicting a dome-shaped detachment fault and antithetic normal faults [deMartin et al., 2007]. The extensional hanging wall hosts relict and active hydrothermal mounds [Tivey et al., 2003]. The locations of relict and shimmering hydrothermal mounds are marked by black and white circles, respectively, and the TAG active mound is at the white star. (C) Bathymetric map of 6,207 epicenters detected on the mound-scale network locate in a seismogenic zone focused to the southwest of the deposit and $<150 \mathrm{~m}$ below the seafloor. Many hypocenters lie within the anhydrite-rich zone and anhydrite-veined alteration zones of the TAG active mound [Humphris et al., 1995; Alt and Teagle, 1998].

A)

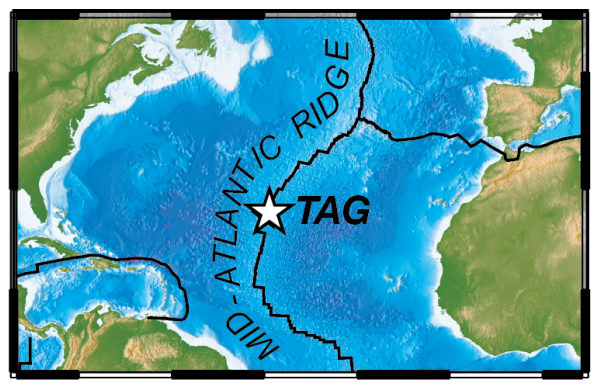

B) Segment-scale catalog

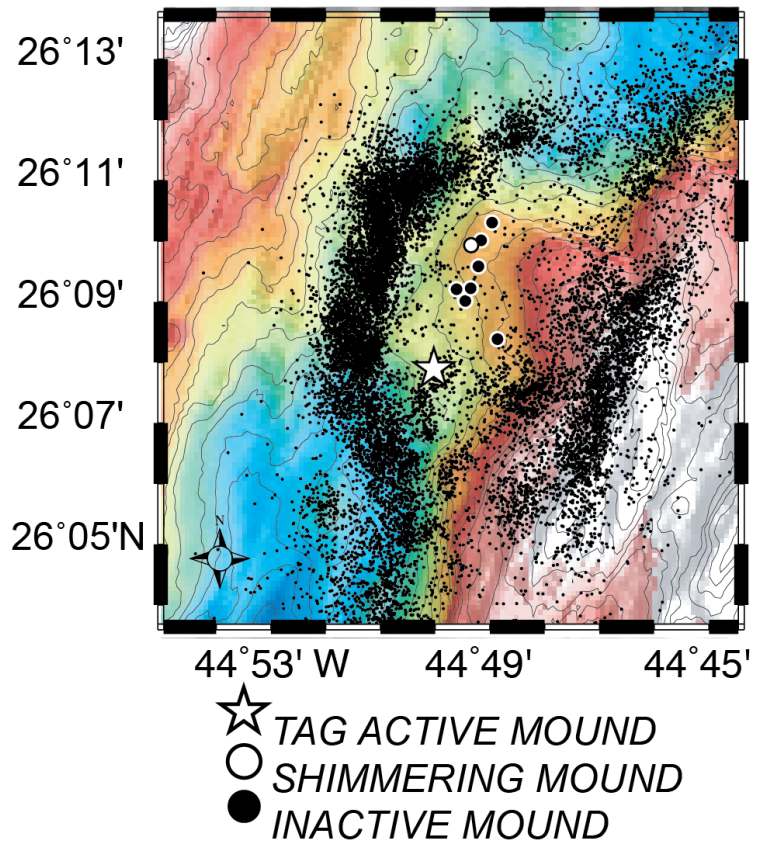

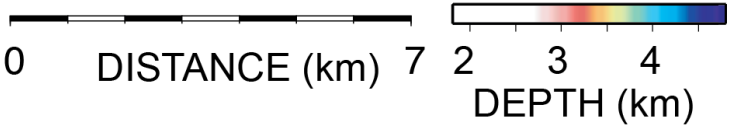

C) Mound-scale catalog

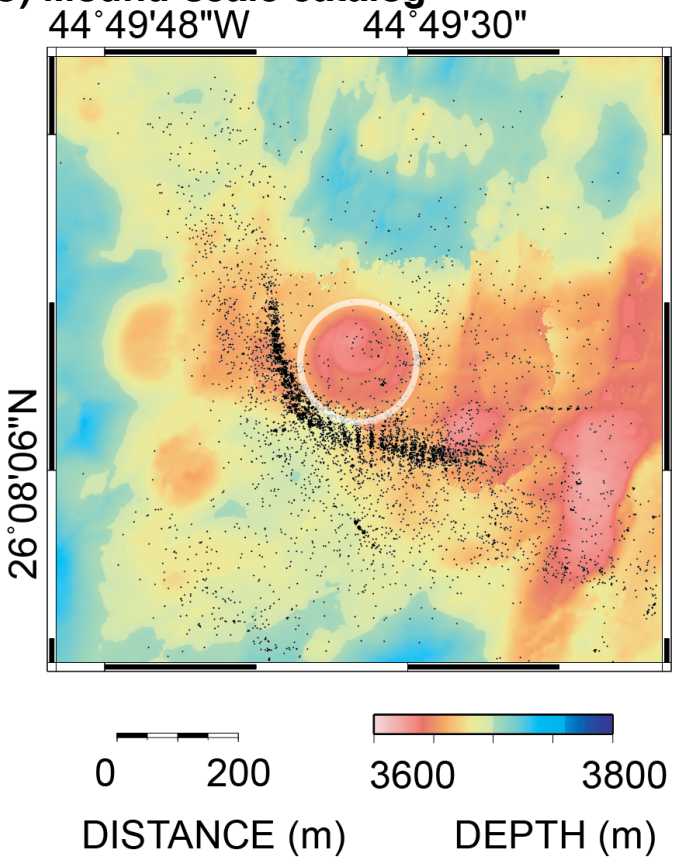


Figure 4. Cumulative event count in time for mound-scale events (blue, $n=32,078$

events) and segment-scale events (red, $n=19,827$ events). Mound-scale event rate is 243 events per day prior to the failure of STIR-12 77 days into the study, at which time event rate decreases to 128 events per day. Average segment-scale event rate is 80 events per day. Whale noise in the area begins in November, masking some microearthquake events and decreasing the observed mound-scale event rate to 97 events per day.

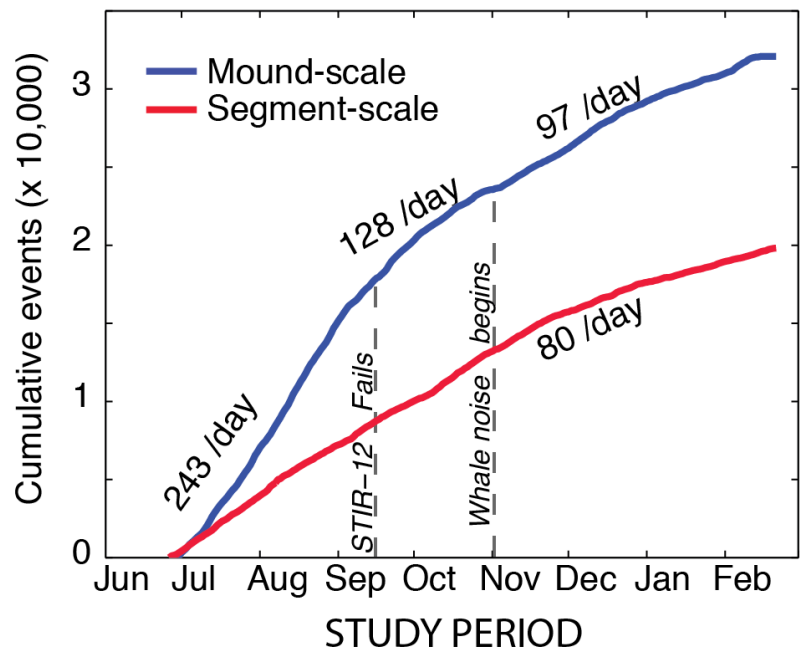


Figure 5. Normalized multitaper spectral estimates $(\mathrm{NW}=5)$ of the (A) mound-scale catalog, (B) segmentscale catalog, (C) pressure gauge data, and (D) solid earth tidal prediction at tidal periods. Coherences of the (E) mound-scale catalog vs pressure gauge data, (F) mound-scale catalog vs solid earth tides show little coherent frequencies at tidal periods. Major tidal constituents (e.g. $\mathrm{O}_{1}, \mathrm{~K}_{1}, \mathrm{M}_{2}, \mathrm{~S}_{2}, \mathrm{MK}_{3}, \mathrm{M}_{4}$ ) are labeled in blue lines [Foreman, 1977]. Coherence at tidal periodicity is evident between the segment-scale microearthquakes and the solid earth tides at $\mathrm{M}_{2}$, the principal lunar semi-diurnal tide.

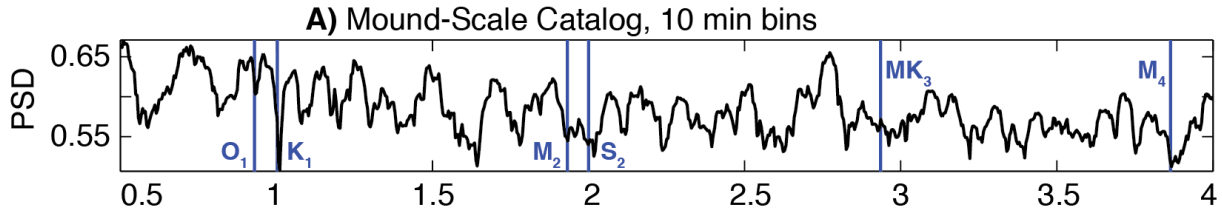

B) Segment-Scale Catalog, 10 min bins
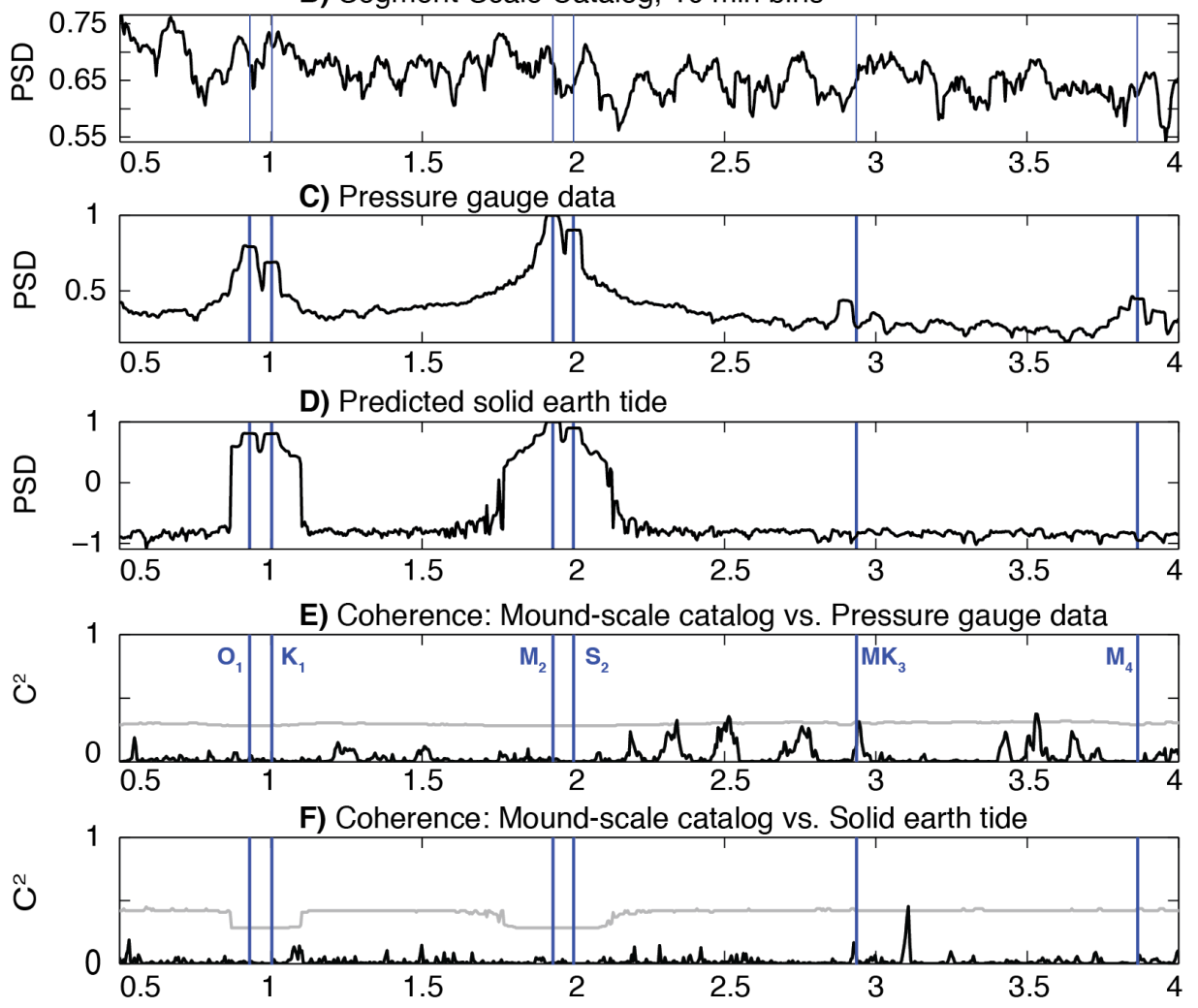

G) Coherence: Segment-scale catalog vs. Pressure gauge data
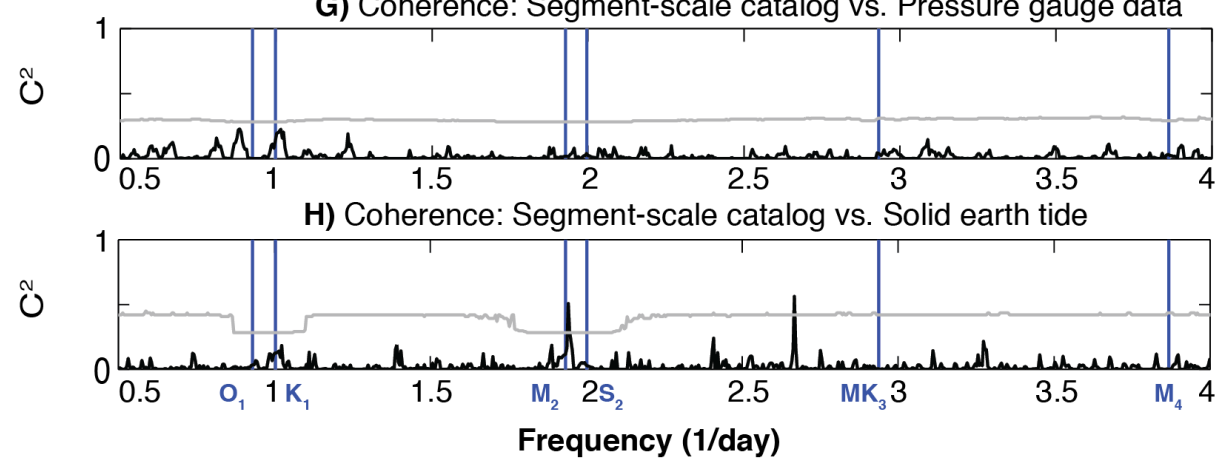
Figure 6. The mound-scale microearthquake catalog as a point process ( 8 minute bins) and exit fluid temperature record for both channels of probe $L 1$ are shown below. The coherence plots (at NW=3) between each probe channel and the mound-scale catalog show the 19 min period at which significant coherence exists between both probes and the catalog (orange line). Results shown are robust to spectral smoothing level. The zero significance level for coherence ( $C^{2}>0$ with $95 \%$ confidence) is depicted as a grey line.
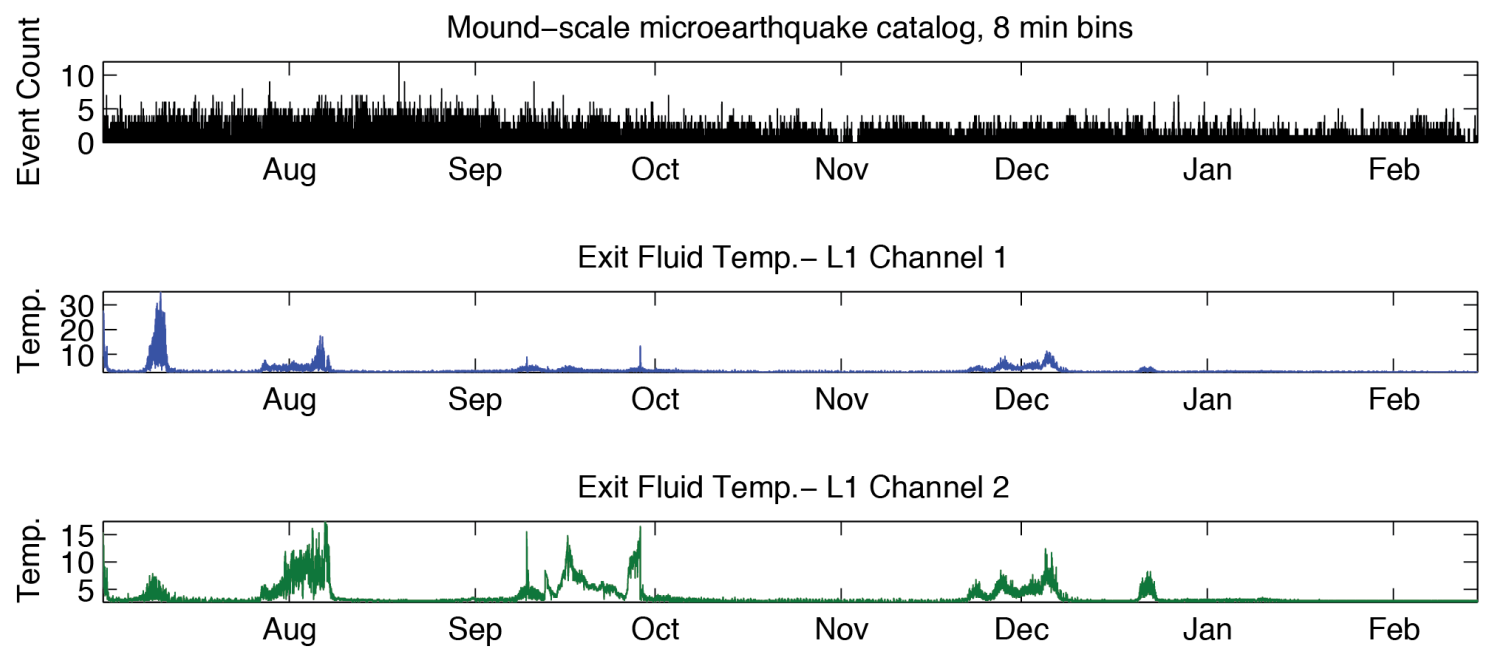

Coherence: L1 Chan-1 vs Mound-scale catalog

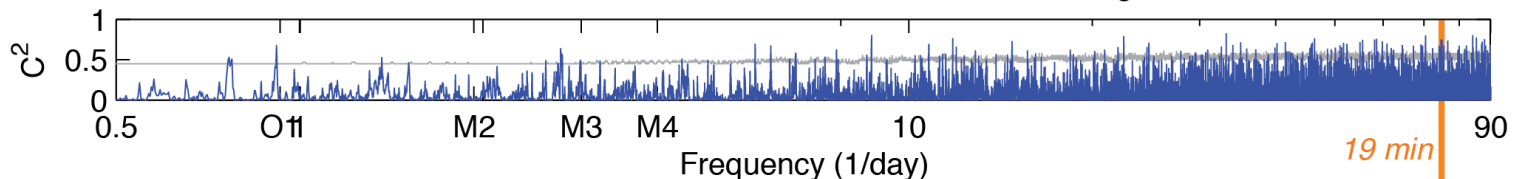

Coherence: L1 Chan-2 vs Mound-scale catalog

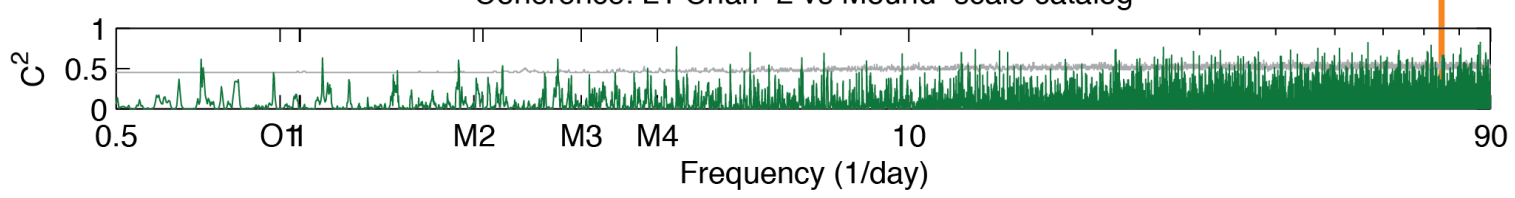


Figure 7. The mound-scale microearthquake catalog as a point process ( 8 minute bins) and exit fluid temperature record for both channels of probe $L 4$ are shown below. The coherence plots (at NW=3) between each probe channel and the mound-scale catalog show 3.1 hour, 1.1 hour, and 20.8 min periods at which significant coherences exist between both probes and the catalog (orange lines). Results shown are robust to spectral smoothing level. The zero significance level for coherence $\left(C^{2}>0\right.$ with $95 \%$ confidence) is depicted as a grey line.

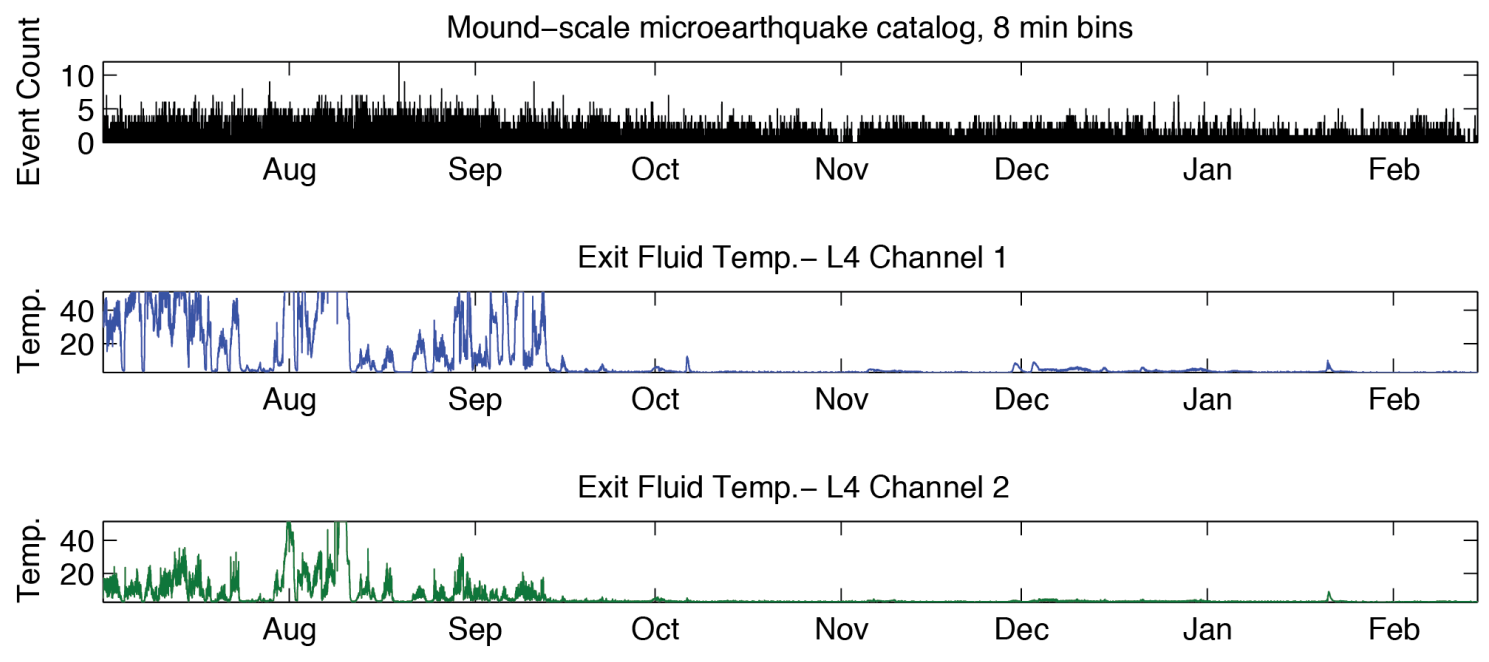

Coherence: L4 Chan-1 vs Mound-scale catalog

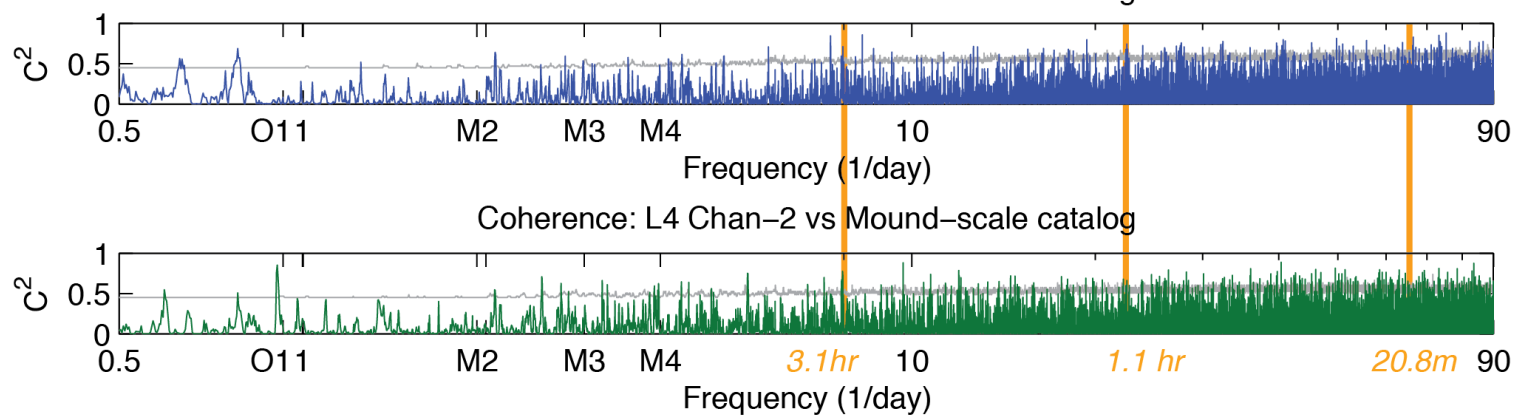


Figure 8. The mound-scale microearthquake catalog as a point process ( 8 minute bins) and exit fluid temperature record for both channels of probe $L 5$ are shown below. The coherence plots (at NW=3) between each probe channel and the mound-scale catalog show the 1.2 day period at which significant coherence exists between both probes and the catalog (orange line). Probe L5 is the only site where a longer coherent period is measured, and the 1.2 day period is slightly longer than the lunar diurnal tidal constituent $\left(\mathrm{O}_{1}\right)$. Results shown are robust to spectral smoothing level. The zero significance level for coherence $\left(C^{2}>0\right.$ with $95 \%$ confidence) is depicted as a grey line.

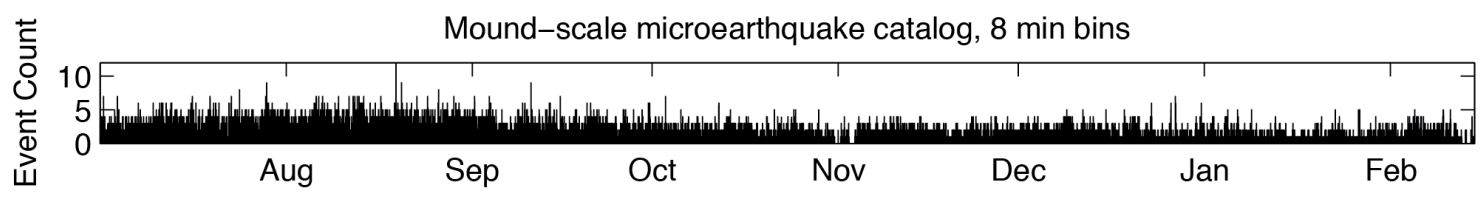

Exit Fluid Temp.- L5 Channel 1

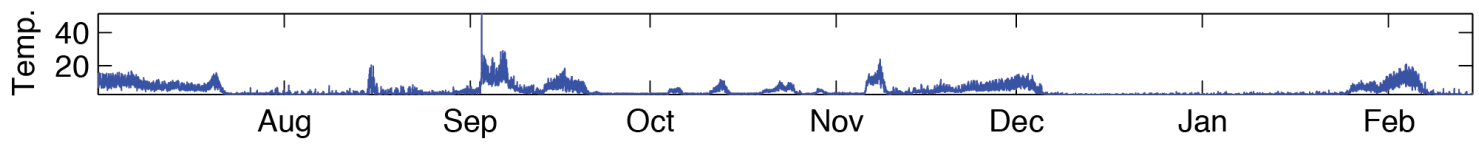

Exit Fluid Temp.- L5 Channel 2

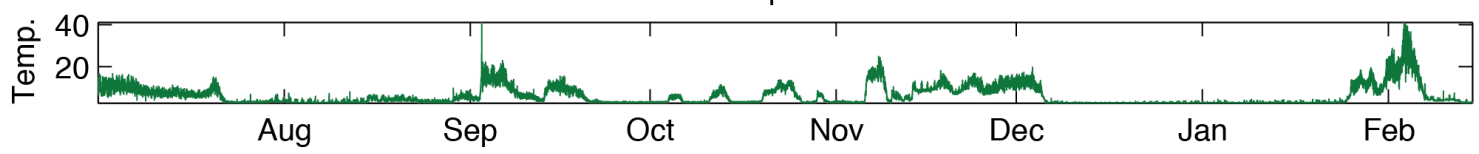

Coherence: L5 Chan-1 vs Mound-scale catalog

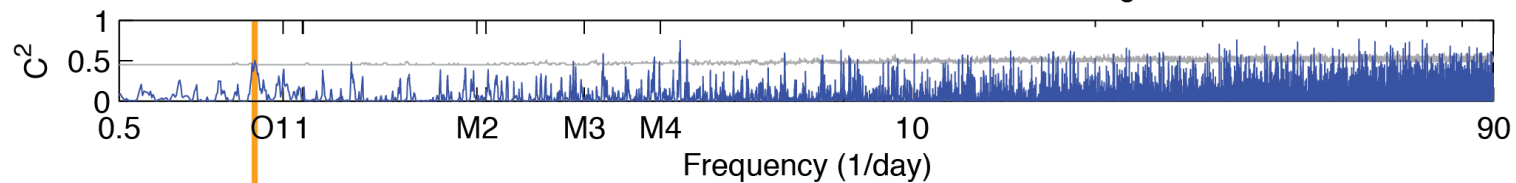

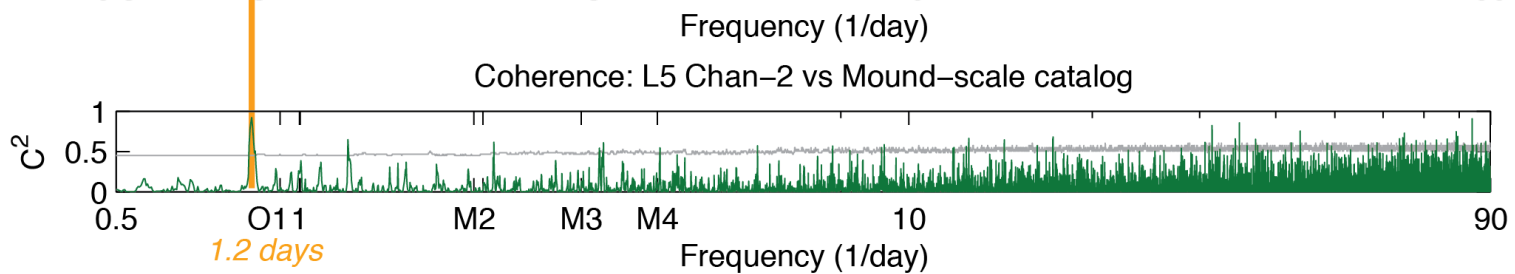


Figure 9. The mound-scale microearthquake catalog as a point process ( 8 minute bins) and exit fluid temperature record for both channels of probe $L 8$ are shown below. The coherence plots (at NW=3) between each probe channel and the mound-scale catalog show the 23.7 min period at which significant coherence exists between both probes and the catalog (orange line). Results shown are robust to spectral smoothing level. The zero significance level for coherence $\left(C^{2}>0\right.$ with $95 \%$ confidence) is depicted as a grey line.
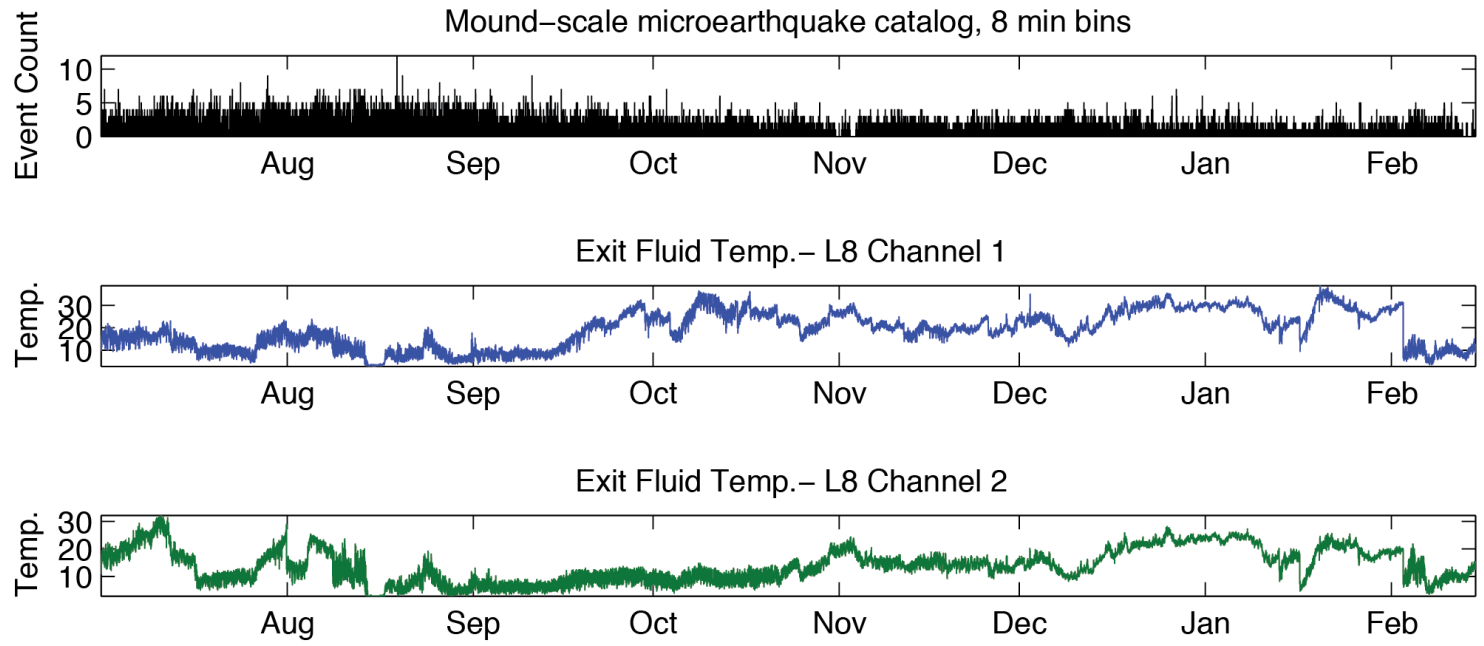

Coherence: L8 Chan-1 vs Mound-scale catalog

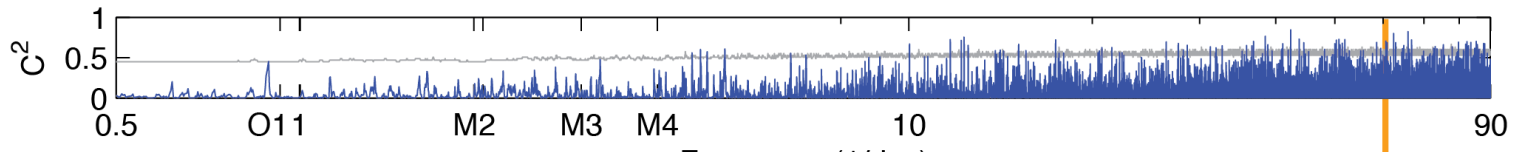

Coherence: L8 Chan-2 vs Mound-scale catalog

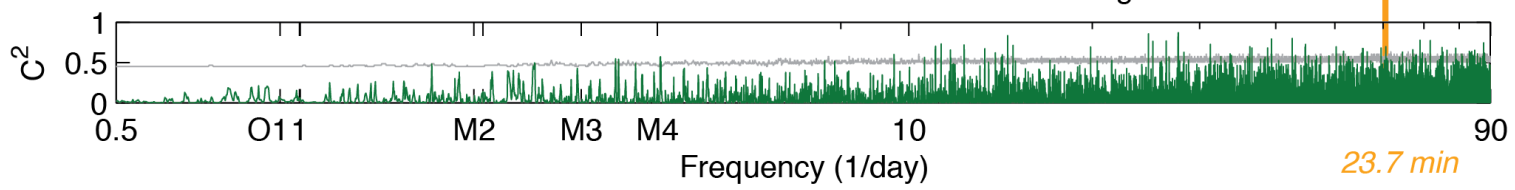


Figure 10. The mound-scale microearthquake catalog as a point process ( 8 minute bins) and exit fluid temperature record for both channels of probe $L 9$ are shown below. The coherence plots (at NW=3) between each probe channel and the mound-scale catalog show the period of $55.2 \mathrm{~min}$ at which significant coherence exists between both probes and the catalog (orange line). Results shown are robust to spectral smoothing level. The zero significance level for coherence $\left(C^{2}>0\right.$ with $95 \%$ confidence) is depicted as a grey line.
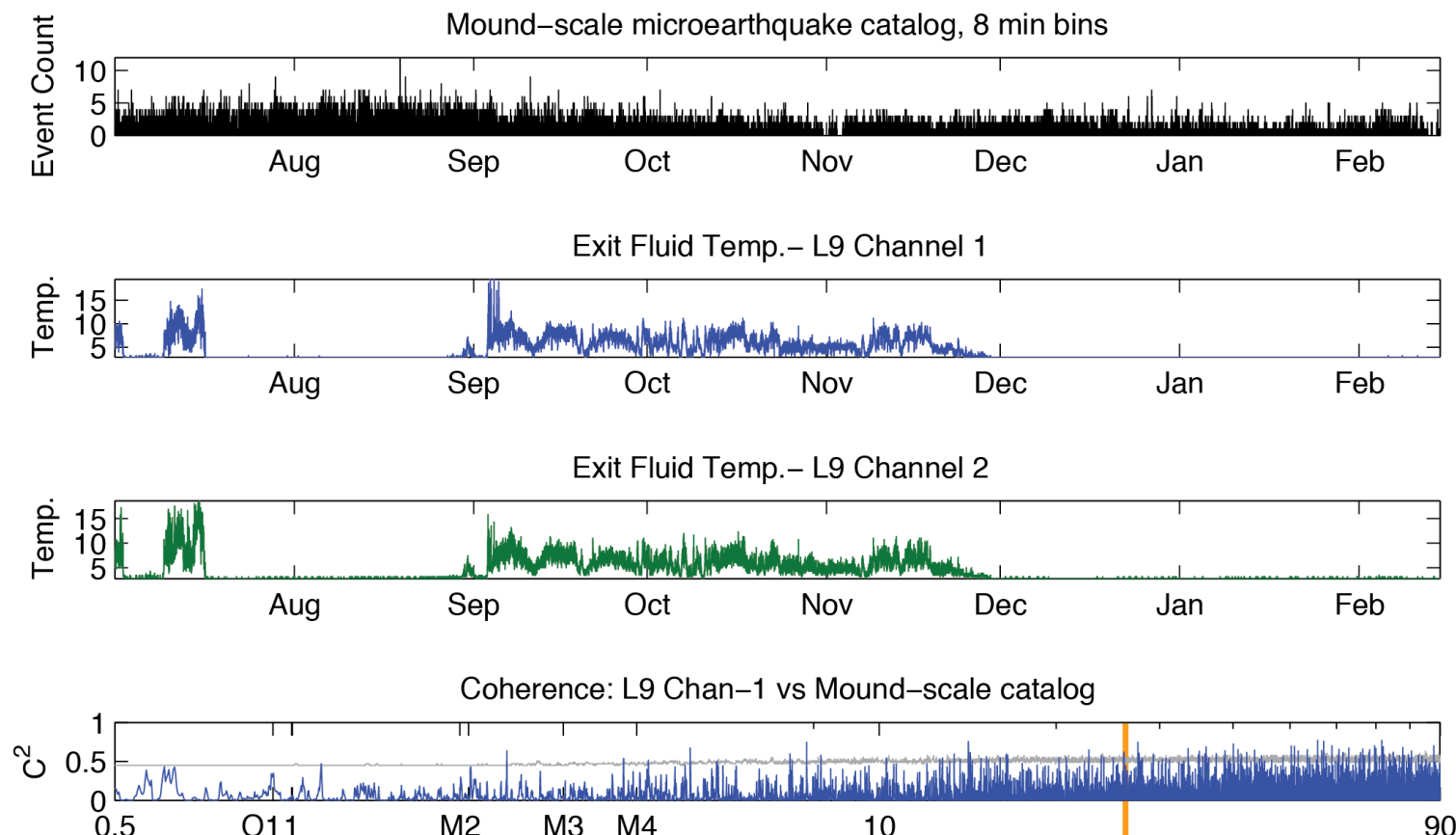

Frequency (1/day)

Coherence: L9 Chan-2 vs Mound-scale catalog 
Figure 11. The mound-scale microearthquake catalog as a point process ( 8 minute bins) and exit fluid temperature record for both channels of probe $L 11$ are shown below. The coherence plots (at NW=3) between each probe channel and the mound-scale catalog show periods of 1.8 hours, $38.9 \mathrm{~min}$, and $21.3 \mathrm{~min}$ at which significant coherences exist between both probes and the catalog (orange lines). Results shown are robust to spectral smoothing level. The zero significance level for coherence $\left(C^{2}>0\right.$ with $95 \%$ confidence) is depicted as a grey line.

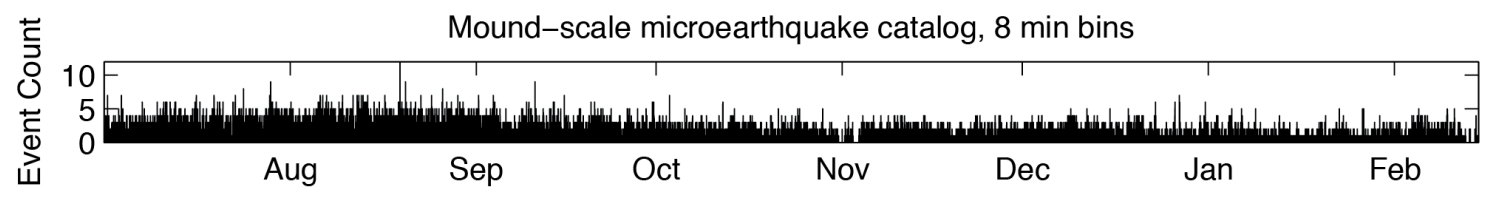

Exit Fluid Temp.- L11 Channel 1

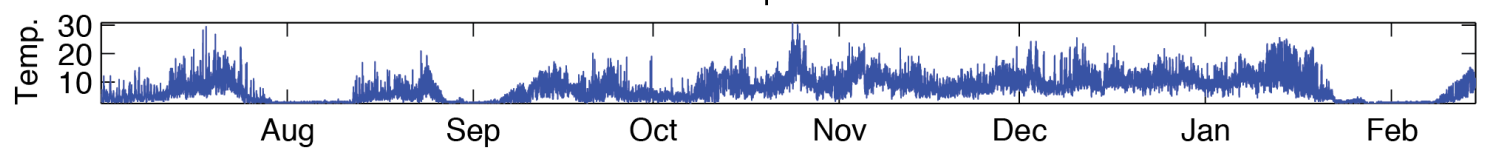

Exit Fluid Temp.- L11 Channel 2

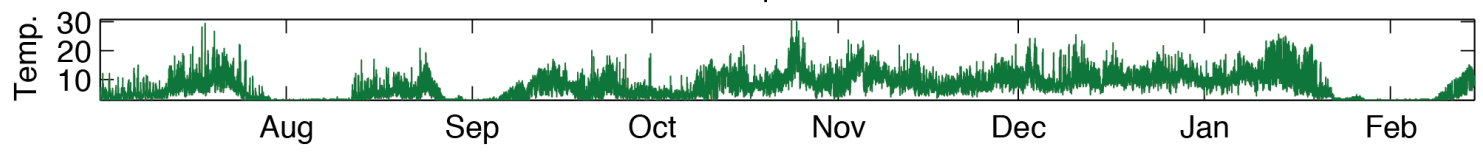

Coherence: L11 Chan-1 vs Mound-scale catalog

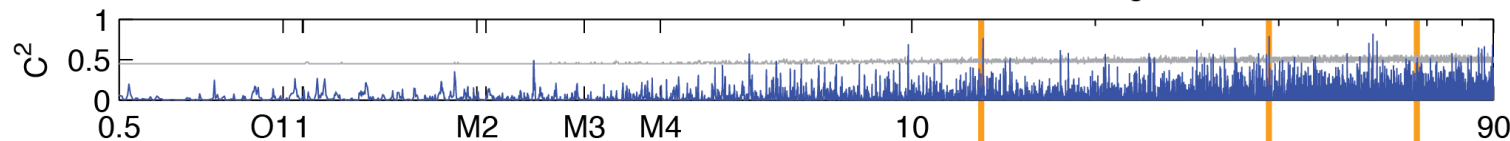

Frequency (1/day)

Coherence: L11 Chan-2 vs Mound-scale catalog

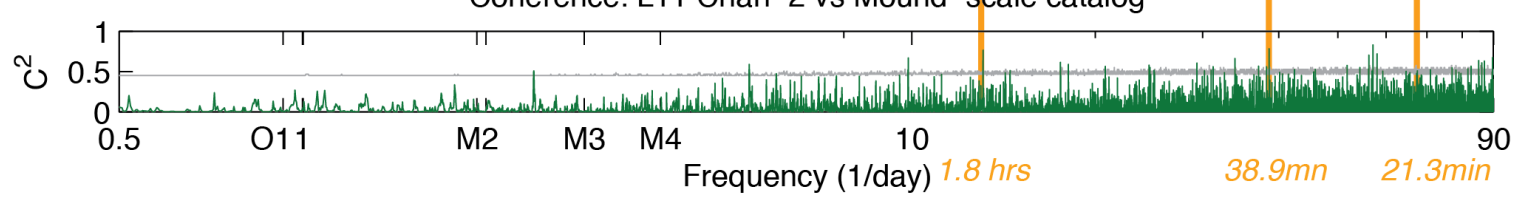


Figure 12. The mound-scale microearthquake catalog as a point process ( 8 minute bins) and exit fluid temperature record for both channels of probe $L 12$ are shown below. The coherence plots (at NW=3) between each probe channel and the mound-scale catalog show periods of 1.5 hours, $23.5 \mathrm{~min}$, and $17.5 \mathrm{~min}$ at which significant coherences exist between both probes and the catalog (orange lines). Results shown are robust to spectral smoothing level. The zero significance level for coherence $\left(C^{2}>0\right.$ with $95 \%$ confidence) is depicted as a grey line.

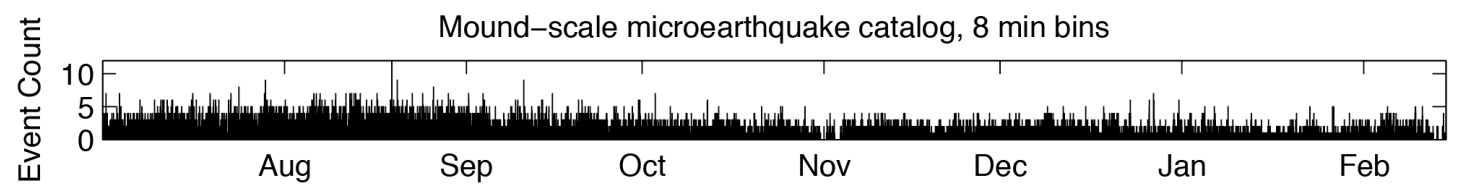

Exit Fluid Temp.- L12 Channel 1

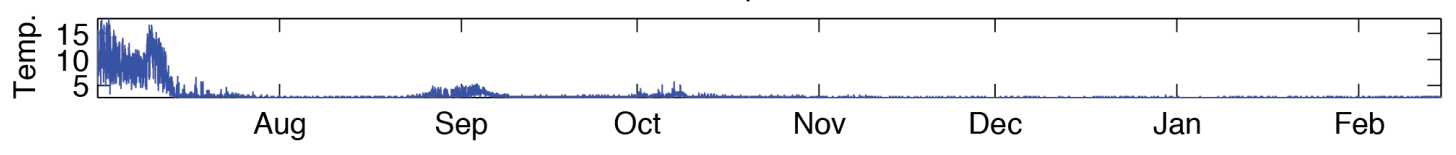

Exit Fluid Temp.- L12 Channel 2

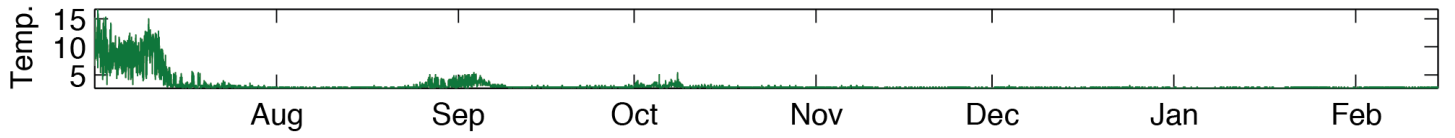

Coherence: L12 Chan-1 vs Mound-scale catalog

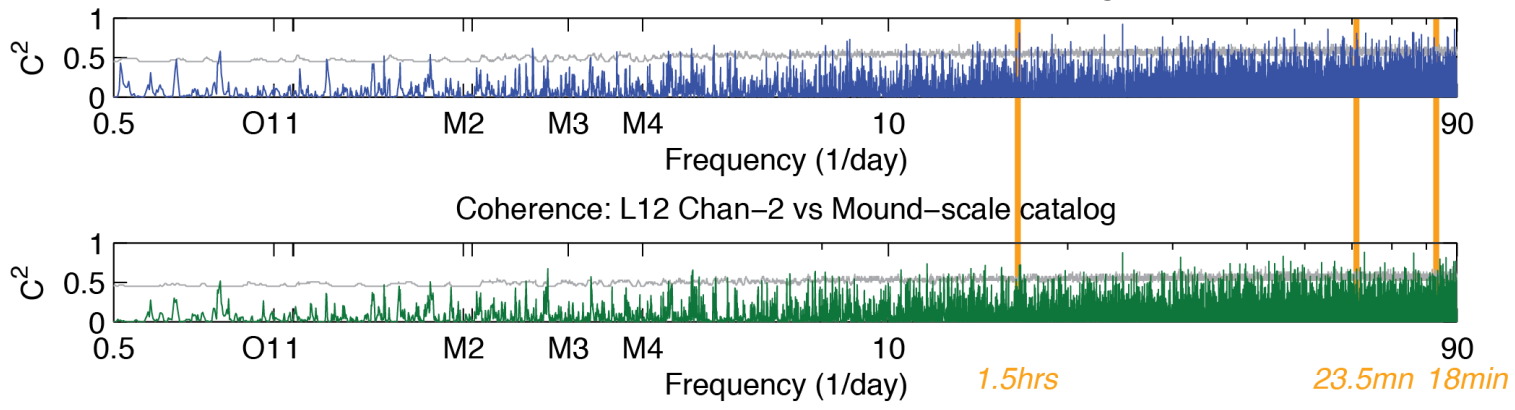


Figure 13. Rotation test distributions ( $\mathrm{n}=1000)$ for (A) L2- Channel 2 and (B) L4Channel 2 compared to the mound-scale microearthquake catalog. Both tests reject the null hypothesis and conclude that mean exit fluid temperature $\left({ }^{\circ} \mathrm{C}\right)$ is significantly higher following mound-scale microearthquake events.

A)

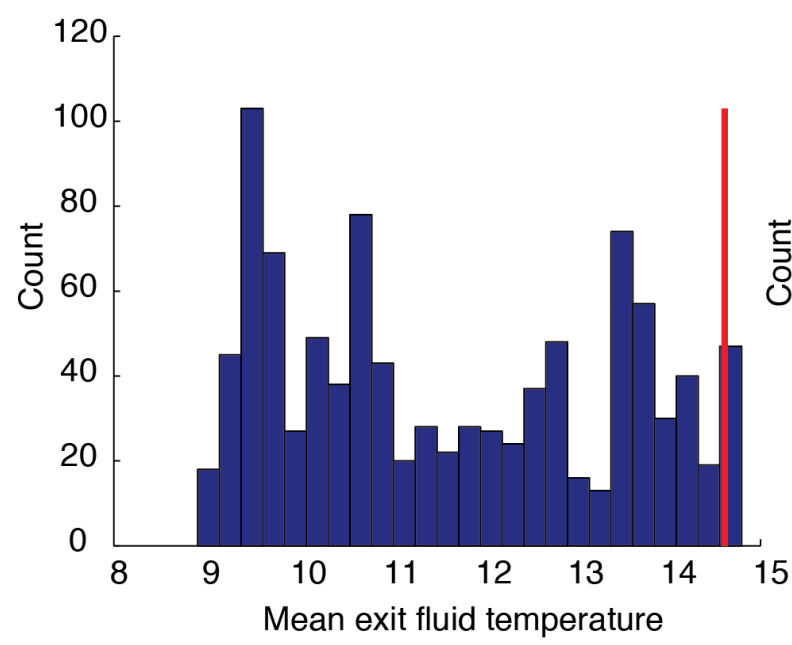

B)

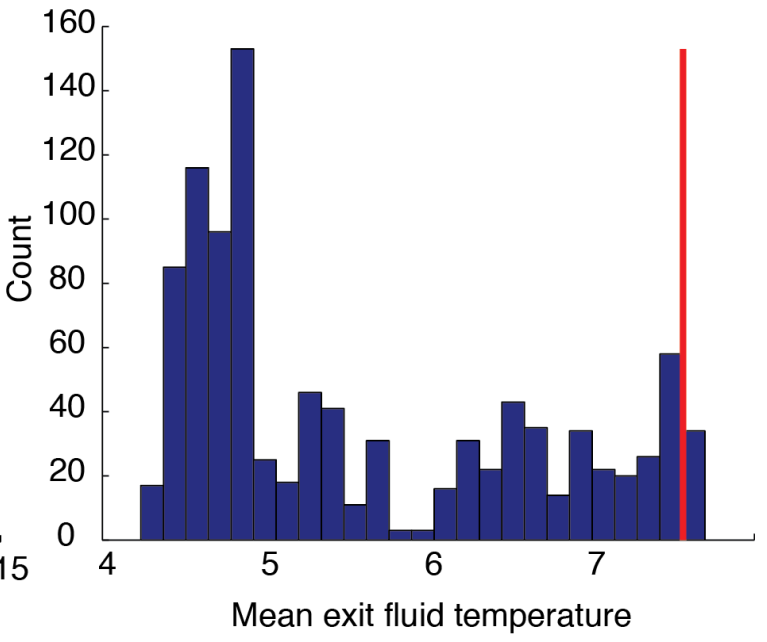


